\title{
AVALIAÇÃO DA DIVERSIDADE GENÉTICA DE \\ ETNOVARIEDADES DE MANDIOCA (Manihot esculenta CRANTZ) \\ COM MARCADORES DE DNA: RAPD, AFLP E \\ MICROSSATÉLITES
}

\section{GILDA SANTOS MÜHLEN}

Engenheira Agrônoma

Orientador: Prof. Dr. AKIHIKO ANDO

Tese apresentada à Escola Superior de Agricultura "Luiz de Queiroz", Universidade de São Paulo, para obtenção do título de Doutor em Agronomia, Área de Concentração: Genética e Melhoramento de Plantas.

PIR A C I C A B A

Estado de São Paulo - Brasil

Julho - 1999 


\section{Dados Internacionais de Catalogação na Publicação (CIP) DIVISÃO DE BIBLIOTECA E DOCUMENTAÇÃO - Campus "LUiz de QUeiroz"/USP}

Muhlen, Gilda Santos

Avaliação da diversidade genética de etnovariedade de mandioca (Manihot esculenta Crantz) com marcadores de DNA: RAPD, AFLP e microssatélites / Gilda Santos Muhlen. - - Piracicaba, 1999.

176 p. : il.

Tese (doutorado) - - Escola Superior de Agricultura Luiz de Queiroz, 1999. Bibliografia.

1. Diversidade genética 2. DNA 3. Germoplasma vegetal 4. Mandioca 5.

Marcador molecular 6. Melhoramento genético vegetal 7 . Variabilidade genética I. Titulo

CDD 633.4

'Permitida a cópia total ou parcial deste documento, desde que citada a fonte - O Autor" 
Dedico esta tese à memória de Paulo Sodero Martins, professor excepcional e pensador brilhante. 


\section{AGRADECIMENTOS}

Registro aqui meus agradecimentos a todos os que de alguma maneira colaboraram para que esta tese chegasse a bom termo.

Faço menção especial ao Prof. Dr. Paulo Sodero Martins, pela orientação no campo da evolução das plantas cultivadas e pela confiança que depositou no meu trabalho de iniciante.

Expresso minha profunda admiração pelo Prof. Dr. Akihiko Ando por assumir a orientação da minha tese e a de outros colegas com desprendimento, por seu senso de responsabilidade e por sua preocupação e apoio irrestrito em tudo que foi necessário

Agraceço à Profa. Dra. Aline A. Pizzirani-Kleiner, por me receber no Laboratório de Microorganismos, durante quase dois anos, para os ensaios de RAPD.

Aos professores: Dra. Maria Lúcia Cameiro Vieira e Dr. Luiz L. Coutinho, pelas sugestões e apoio na solução de inúmeros problemas relativos aos marcadores de DNA.

Ao Prof. Dr. Roland Vencovsky e a Dra. Myriam Cristina Duque, pela orientação na análise estatística dos dados.

Ao Dr. William Roca por autorizar meu estágio no Laboratório de Biotecnologia do CIAT e ao Dr. Joseph Tohme por providenciar todas as facilidades para os ensaios de microssatélites e AFLP, inclusive os iniciadores marcados com fluorescência.

À Ana Carolina Roa Rodrigues e Peter Wentzl, pela amizade e por me receberam em sua casa, em Palmira, durante os cinco meses em que estagiei no CIAT.

Ao Dr. Roberto Cury, pela leitura criteriosa do manuscrito desta tese e pelas interessantes sugestões para a análise dos dados.

A todos os colegas dos diversos laboratórios onde tive a satisfação de trabalhar, pelo companheirismo, entusiasmo e pela valiosa troca de experiências.

Em especial ao Nivaldo Peroni, Maria Inez F. Faraldo, Rainério Meireles da Silva, Julianno B. M. Sambatti e Marianne Elias, pela convivência enriquecedora durante o período de doutorado e pelas conversas esclarecedoras na etapa final de redação da tese. 
Aos funcionários do Departamento de Genética da ESALQ que direta ou indiretamente colaboraram para que meus ensaios tivessem bons resultados, em especial ao José Antonio da Silva e Carlos de Oliveira, pela ajuda no laboratório, à Silvana Marchizelli Gregório, Aparecida Elizabeth dos Santos da Silva e Silvana Cristina Nascimento Oliveira, pela tolerância com meus excessos no uso da biblioteca, à Neusa Maria Sarto Rocha pela incrivel organização e por resolver todos os problemas de contabilidade do projeto, à Cândida Vanderléia de Oliveira e à Carmem Maria S. F. Pilotto, pela amizade e orientação nos trâmites administrativos da ESALQ, ao Ronaldo J. Rabello pelo apoio no trabalho de campo, ao Fernando Leopoldino, Antonio de Pádua Gorga e Marcos Antonio Gorga pela gentileza no atendimento e nas urgências do Xerox e ao José e toda a equipe da Fazenda Anhembi pelo zelo e dedicação em manter a coleção de germoplasma de mandioca.

Por fim, agradeço à FAPESP pelo apoio financeiro que tornou possivel o desenvolvimento deste Projeto. 


\section{SUMÁRIO}

Página

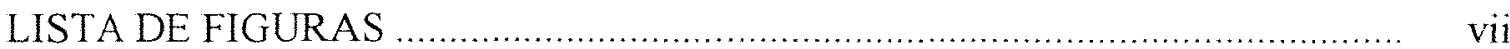

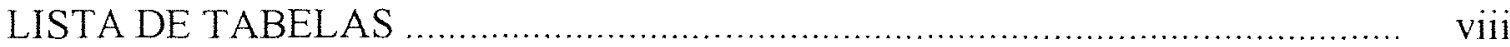

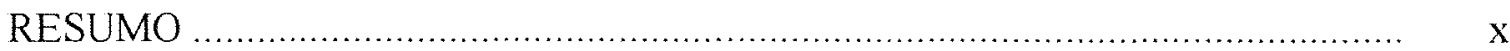

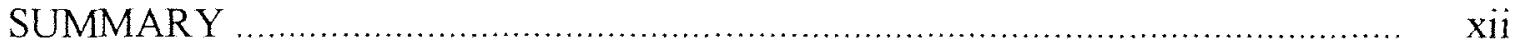

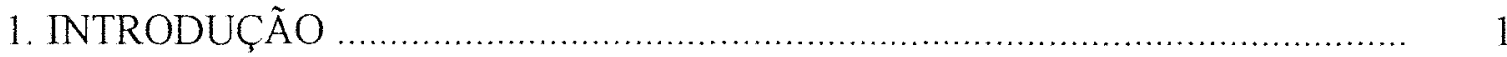

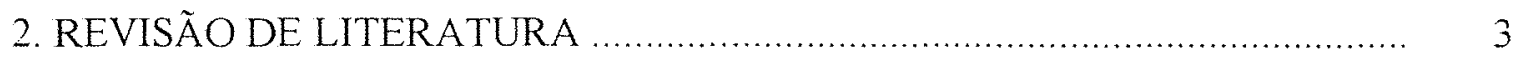

2.1. A mandioca ........................................................................... 3

2.1.1. Diversidade da mandioca: número de variedades ............................... 5

2.1.2. Diversidade da mandioca: variabilidade genética ................................ 7

2.1.3. Geração, manutenção e perda de variabilidade genética da mandioca ........... 10

2.1.4. Mandioca brava, aipim e macaxeira .......................................... 14

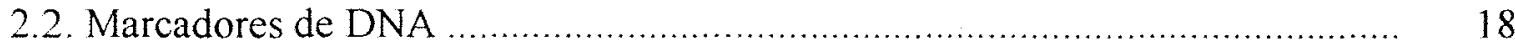

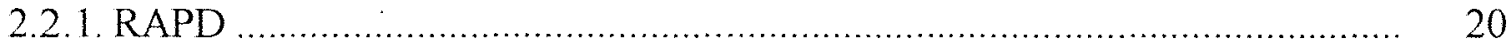

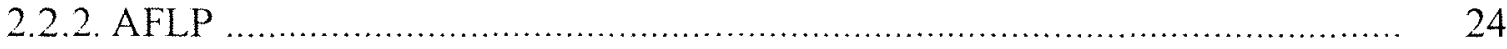

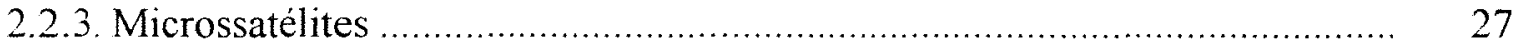

2.2.4. Avaliação da diversidade genética em plantas cultivadas............................ 33

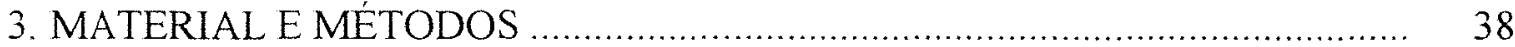

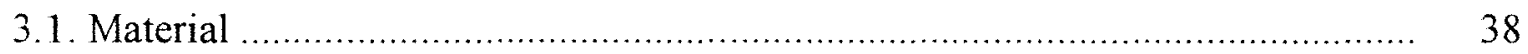

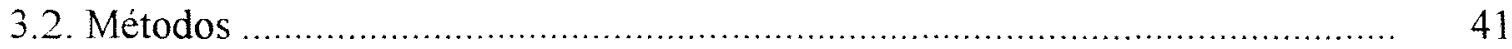

3.2.1. Metodologia para extração de DNA .............................................................. 41

3.2.2. Metodologia para obtenção de bandas de RAPD .................................. 43

3.2.3. Metodologia para obtenção de bandas de microssatélites ................................ 47

3.2.4. Metodologia para obtenção de bandas de AFLP ...................................... 50

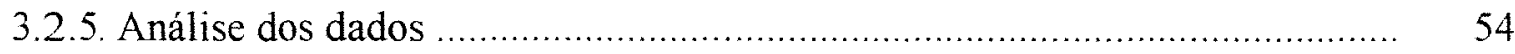

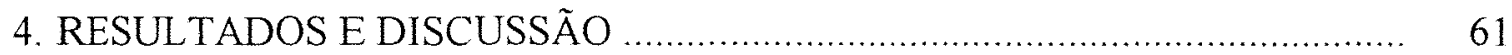

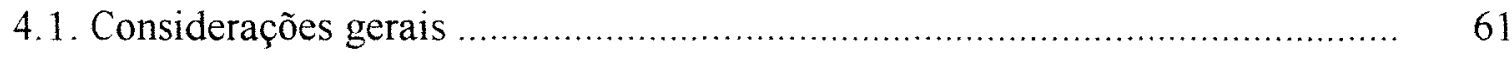

4.2. Distribuição geral das bandas de RAPD, AFLP e microssatélites ................ 62 
4.3. Distribuição das bandas por grupos de variedades de mandioca ..................... 64

4.4. Análise dos alelos de microssatélites ..................................................... $\quad 70$

4.5. Análise dos índices de similaridade entre 55 variedades de mandioca ............ 73

4.6. Agrupamento das 55 variedades de mandioca por similaridade ................... 77

4.7. Análise de coordenadas principais (PCoA) ……......................................... 85

4.8. Considerações finais .............................................................................. 91

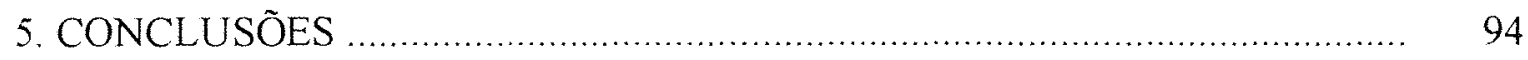

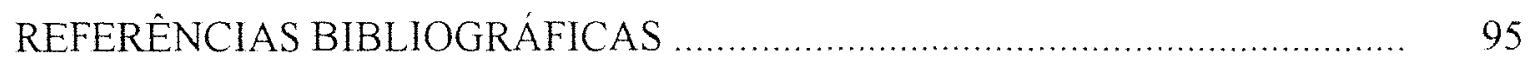

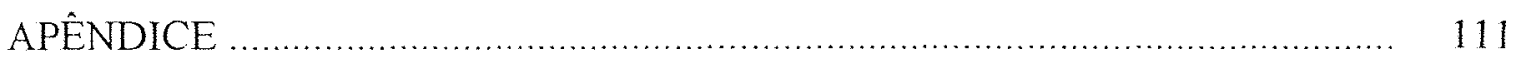




\section{LISTA DE FIGURAS}

Página

Figura 1A - Modelo de Dinâmica Evolutiva da Mandioca

Figura $1 \mathrm{~B}$ - Eventos de dinâmica evolutiva da mandioca

Figura 2 - Distribuição histórica de variedades bravas e mansas de mandioca

Figura 3 - Esquema explicativo da técnica de AFLP 25

Figura 4 - Esquema explicativo da amplificação de microssatélites 31

Figura 5 - Fotografia de gel para separação de fragmentos para análise de RAPD 45

Figura 6 - Gráficos representando os alelos dos locos de microssatélites 48

Figura 7 - Gráficos representando as bandas de AFLP 53

Figura 8 - Dendrograma com 4 grupos de variedades de mandioca 78

Figura 9 - Dendrograma com 55 variedades de mandioca (RAPD) 80

Figura 10 - Dendrograma com 55 variedades de mandioca (AFLP) 81

Figura 11 - Dendrograma com 55 variedades de mandioca (microssatélites) 82

Figura 12 - Dendrograma com 55 variedades de mandioca (todos os marcadores) 83

Figura 13 - Dispersão de 55 variedades de mandioca (PCoA - RAPD) .............. 87

Figura 14 - Dispersão de 55 variedades de mandioca (PCoA - AFLP) .............. 88

Figura 15 - Dispersão de 55 variedades de mandioca (PCoA-microssatélites) ... 89

Figura 16 - Dispersão de 55 variedades de mandioca (PCoA - todas as bandas) ... 90 


\section{LISTA DE TABELAS}

Página

Tabela 1 - Conteúdo de DNA de espécies de Manihot

Tabela 2 - Variedades de mandioca

Tabela 3 - Proporção de bandas polimórficas e monomórficas

Tabela 4 - Distribuição das bandas polimórficas segundo sua freqüência

Tabela 5 - Bandas ausentes nos grupos de variedades de mandioca

Tabela 6 - Proporção de bandas monomórficas e polimórficas, por grupo

Tabela 7 - Distribuição das bandas polimórficas segundo sua freqüencia, por grupo

Tabela 8 - Número de alelos em 11 microssatélites, por grupo

Tabela 9 - Número de genótipos distintos em 11 microssatélites, por grupo

Tabela 10 - Freqüência de heterozigotos em 11 microssatélites, por grupo

Tabela 11 - Índices de diversidade (ID), para 11 locos de microssatélite, por grupo

Tabela 12 - Valores de $\mathrm{G}_{\mathrm{ST}}, \mathrm{H}_{\mathrm{T}}$, e $\mathrm{H}_{\mathrm{S}}$ para 11 locos de microssatélite, por região.... 74

Tabela 13 - Valores de $\mathrm{G}_{\mathrm{ST}}, \mathrm{H}_{\mathrm{T}}$, e $\mathrm{H}_{\mathrm{S}}$ para 11 locos de microssatélite, por tipo 74

Tabela 14 - Índices de similaridade de Nei \& Li, entre 55 variedades de mandioca 76

Tabela 15 - Índices médios de similaridade entre e dentro de grupos (RAPD) 76

Tabela 16 - Índices médios de similaridade entre e dentro de grupos (AFLP) 76

Tabela 17 - Índices médios de similaridade entre e dentro de grupos (microssatélites) 76

Tabela 18 - Índices médios de similaridade, por tipo de variedade 76

Tabela 19 - Correlações cofenéticas, para os três tipos de marcadores 83

Tabela 20 - Correlações entre matrizes de similaridade: momento-produto ( $\mathrm{r}$ ) ......

Tabela 21 - Correlações entre matrizes de similaridade: por ordenação (Spearman) 79

Tabela 22 - Correlação entre diferentes matrizes de similaridade geradas por AFLP 79

Tabela 23 - Auto valores para os primeiros dez eixos, de PCoA (RAPD)

Tabela 24 - Auto valores para os primeiros dez eixos, de PCoA (AFLP).

Tabela 25 - Auto valores para os primeiros dez eixos, de PCoA (microssatélites) 86

Tabela 26 - Auto valores para os primeiros dez eixos, de PCoA (todas as bandas) 
Anexo 2 - Presença e ausência de 134 bandas de AFLP

Anexo 3 - Presença e ausência de 49 bandas de 11 microssatélites

Anexo 4 - Freqüência de bandas de RAPD, por grupo

Anexo 5 - Freqüência de bandas de AFLP, por grupo

Anexo 6 - Freqüência de bandas de microssatélites, por grupo

Anexo 7 - Genótipo de cada variedade de mandioca em 11 locos de microssatélites 154

Anexo 8 - Freqüência de combinações de alelos em 11 locos de microssatélites ..... 157

Anexo 9 - Locos heterozigotos de microssatélites em 55 variedades de mandioca 159

Anexo 10 - Índices de similaridade entre variedades de mandioca (RAPD) .......... 161

Anexo 11 - Índices de similaridade entre variedades de mandioca (AFLP) .......... 166

Anexo 12 - Índices de similaridade entre variedades de mandioca (microssatélites) 171

Anexo 13 - Correlações entre matrizes de similaridade - dados completos ............ 176 


\begin{abstract}
AVALIAÇÃO DA DIVERSIDADE GENÉTICA DE ETNOVARIEDADES DE MANDIOCA (Manihot esculenta CRANTZ) COM MARCADORES DE DNA: RAPD, AFLP E MICROSSATÉLITES
\end{abstract}

Autora: GILDA SANTOS MÜHLEN Orientador: Prof. Dr. AKIHIKO ANDO

\title{
RESUMO
}

A diversidade genética de 55 acessos de mandioca foi avaliada por meio de marcadores de DNA. Todos os acessos pertencem à coleção de germoplasma do Departamento de Genética da Escola Superior de Agricultura "Luiz de Queiroz" (Piracicaba - SP - Brasil).

Foram escolhidas 45 etnovariedades da região Amazônica (23 do Rio Negro, 6 do Rio Branco e 16 do Rio Solimões), 9 etnovariedades do Litoral Sul do Estado de São Paulo e 1 variedade comercial (Mantiqueira). Das 55 variedades, 17 são aipins (ou macaxeiras) e 38 são mandiocas bravas.

Foram usados três tipos de marcadores de DNA: RAPD, AFLP e microssatélites. Estes marcadores produziram 339 bandas: 156 bandas de RAPD, sendo $87(55,8 \%)$ polimórficas; 134 bandas de AFLP, sendo $93(69,4 \%)$ polimórficas e os 11 locos de microssatélites geraram 49 bandas (alelos), sendo $48(98,0 \%)$ polimórficas.

Para os microssatélites, o número de alelos por loco variou de 2 a 8 , com média de 4,5 alelos. Quanto à porcentagem de locos heterozigotos por indivíduo, o mínimo foi $27 \%$ e o máximo $91 \%$, com média de $56 \%$. As etnovariedades do Litoral de São Paulo apresentaram uma média de locos heterozigotos maior que as da Amazônia com 75\% e $53 \%$, respectivamente. Os índices de diversidade (ID) para cada loco variaram de $\mathrm{ID}=0,02$ a $\mathrm{ID}=0,79$, com média de $\mathrm{ID}=0,55$.

Considerando o agrupamento das plantas em função do local de origem, a variabilidade genética dentro dos grupos foi superior à variabilidade entre os grupos. Os coeficientes de diferenciação genética, calculados para os 11 locos de microssatélites, 
tiveram um valor médio de $G_{\mathrm{ST}}=0,07$. Considerando o agrupamento em função de tipo de mandioca (aipim ou mandioca brava), obteve-se o valor médio de $\mathrm{G}_{\mathrm{ST}}=0,04$.

Foram calculados índices de similaridade (Nei \& Li) para os três tipos de marcador. Para RAPD, o valor mínimo foi de $S=0,81$, máximo de $S=0,99$ com média de $S=0,89$. Para AFLP, o mínimo foi de $S=0,85$, máximo de $S=1,00$ e média de $S=0,75$. Para microssatélites, o mínimo foi de $S=0,24$, máximo de $S=1,00$ e média de $S=0,59$. As correlações entre as três matrizes de similaridade foram iguais e baixas, com $r=0,40$.

Dendrogramas construidos a partir dos três tipos de marcador, nâo definem agrupamentos muito claros e são bastante diferentes entre si. Porém, um padrão é comum a todos: a separação entre aipins (ou macaxeiras) e as mandiocas bravas. As correlações cofenéticas foram: $r=0,81$ para $\mathrm{RAPD}, \mathrm{r}=0.69$ para AFLP e $r=0,73$ para microssatélites.

Análise de coordenadas principais (PCoA), para cada um dos marcadores, confirmou a divisão entre mandiocas bravas e aipins (ou macaxeiras). No grupo dos aipins estão incluídas todas a etnovariedades do Litoral Sul de São Paulo, a variedade comercial Mantiqueira e mais 7 etnovariedades dos três locais de coleta na Amazônia.

Este estudo confirmou que os marcadores de DNA são úteis na avaliação da variabilidade genética de etnovariedades de mandioca e apontou uma possivel divisão genética do germoplasma desta espécie em dois grupos: mandiocas bravas e aipins (ou macaxeiras). 


\title{
ASSESSMENT OF GENETIC DIVERSITY OF CASSAVA (Manihot esculenta \\ CRANTZ) FOLK VARIETIES BY DNA MARKERS: RAPD, AFLP AND \\ MICROSATELLITES
}

\author{
Author: GILDA SANTOS MÜHLEN \\ Advisor: Prof. Dr. AKIHIKO ANDO
}

\section{SUMMARY}

Genetic diversity of 55 accessions of cassava was assessed by DNA markers. All accessions belong to the germplasm collection maintained at the Department of Genetics, College of Agriculture "Luiz de Queiroz" (Piracicaba - São Paulo State Brazil).

The accessions studied consisted of 45 folk varieties from the Amazonian region (23 from Negro River, 6 from Branco River and 16 from Solimões River), 9 folk varieties from South Coast of São Paulo State, and 1 modern variety (Mantiqueira). Among these 55 varieties, 17 were "sweet" ones ("aipins" or "macaxeiras") and 38 were "bitter" ones.

Three types of DNA markers were used: RAPD, AFLP and microsatellites. These markers produced 339 scored bands: 156 RAPD bands, $87(55,8 \%)$ polymorphic ones; 134 AFLP bands, $93(69,4 \%)$ polymorphic ones and the 11 microsatellites produced 49 bands (alleles), 49 (98,0\%) polymorphic ones.

The number of microsatellite alleles per locus varied from 2 to 8 , with a mean value of 4,5 alleles. The rate of heterozygous loci per individual varied from a minimum of $27 \%$ to a maximum of $91 \%$, with a mean value of $56 \%$. The folk varieties from São Paulo State had a mean value of heterozygous loci higher than the Amazonian folk varieties, $75 \%$ and $53 \%$, respectively. The diversity index (DI) of each locus varied from $\mathrm{DI}=0,02$ to $\mathrm{DI}=0,79$, and the mean value was $\mathrm{DA}=0,55$.

Considering the four groups of varieties (three groups from Amazonian subregions and one group from the South Coast of São Paulo State) the amount of genetic 
variability inside groups was higher then that among groups. The genetic differentiation coefficients $\left(\mathrm{G}_{\mathrm{ST}}\right)$, estimated to 11 microsatellite loci, had a mean value of $\mathrm{G}_{\mathrm{ST}}=0,07$.

Similarity indexes (Nei \& Li) were calculated for each marker type. For RAPD data the minimum value was $S=0,81$, the maximum was $S=0,99$ and the mean value was $\mathrm{S}=0,89$. For AFLP data the minimum value was $\mathrm{S}=0,85$, the maximum value was $\mathrm{S}=1,00$ and the mean value was $\mathrm{S}=0,75$. For microsatellite data the minimum was $S=0,24$, the maximum was $S=1,00$ and the mean value was 0,59 . The correlation among the three similarity matrices were equal and low $(r=0,40)$.

Dendrograms were built from UPGMA clustering, to each kind of markers. They did not define clear groups and they are quite different. However, a pattern was common to all: a division among sweet and bitter cassava. The cophenetic values were $r=0,81$ to RAPD, $r=0,69$ to AFLP and $r=0,73$ to microsatellites.

Principal coordinate analysis (PCoA), separately made to each marker type, confirmed the clustering of sweet and bitter cassava varieties. In the sweet varieties group, all folk varieties from São Paulo State, the modern cultivar Mantiqueira and 7 folk varieties from the three Amazonian collection sites were included.

This study confirmed that DNA markers are useful to the assessment of genetic variability of cassava folk varieties and pointed a possible division of the germplasm of this species in two groups: sweet and bitter. Since the geographic division coincided greatly with this grouping and the sampling in the present work was not sufficient, more investigation is necessary to confirm this possibility. 


\section{INTRODUÇÃO}

Uma das linhas de pesquisa do Laboratório de Genética Ecológica da ESALQ envolve a dinâmica evolutiva das plantas domesticadas e amplamente cultivadas desde 0 periodo pré-colombiano, nas terras baixas tropicais do continente americano.

Estas plantas são fundamentais em vários sistemas agricolas tradicionais, ainda vigentes no Brasil e a mandioca é, freqüentemente, a espécie predominante. Uma das características desta agricultura tradicional é gerar e manter uma quantidade grande de variedades das espécies cultivadas. Estas etnovariedades ("landraces", "folk varieties") constituem uma reserva de variabilidade genética que tem um papel importante na estabilidade da produção agrícola.

Na região amazônica, sobretudo entre os grupos indigenas. as etnovariedades de mandioca se contam às dezenas. Possivelmente, sua riqueza genética é considerável. No entanto, sua representação nas principais coleções de germoplasma e seu uso em programas oficiais de melhoramento são quase nulos. Os conhecimentos sobre as características agronômicas, de resistência a pragas e doenças, adaptação a diferentes condições ambientais destas variedades são restritos às comunidades que as utilizam.

Com o intuito de iniciar um estudo sobre as etnovariedades de mandioca da Amazônia, foram feitas duas coletas na região do Rio Negro, Rio Branco, Rio Solimões e médio Amazonas, que renderam mais de 100 etnovariedades.

Uma primeira estimativa da variabilidade genética deste material foi feita para 45 destas etnovariedades: Cury (1998) avaliou caracteres morfológicos, agronômicos e bioquimicos, Faraldo (no prelo) utilizou isoenzimas e o presente trabalho apresenta os resultados obtidos com marcadores de DNA.

Este é o primeiro trabalho realizado no Laboratório de Ecologia Evolutiva com marcadores de DNA. Teve, portanto, um caráter de projeto piloto e a função de avaliar a conveniência de se acrescentar mais estas ferramentas da genética molecular aos projetos desenvolvidos no Laboratório.

Seus objetivos foram: 
1 - Quantificar e verificar a distribuição da variabilidade genética de uma amostra de etnovariedades de mandioca coletada na Amazonia.

2 - Avaliar a eficiência de RAPD, AFLP e microssatélites para o estudo da diversidade genética de etnovariedades de mandioca.

3 - Fornecer subsidios para a comparação entre diferentes abordagens no estudo da diversidade genética de etnovariedades de mandioca, quais sejam: avaliação de caracteres morfológicos, agronômicos e bioquímicos; avaliação de variabilidade isoenzimática e avaliação de polimorfismos de DNA. 


\section{REVISÃO DE LITERATURA}

\subsection{A Mandioca}

A mandioca pertence ao gênero Manihot, Euphorbiaceae, que é nativo do continente americano e tem ampla distribuição geográfica, desde $33^{\circ}$ de latitude norte até $35^{\circ}$ de latitude sul. As espécies que compõem este gênero são perenes e têm hábitos de crescimento que variam desde arbustos acaulescentes até árvores com 10 a 12 metros de altura (Rogers \& Appan, 1973; Allem, 1989a; Allem, 1989b; Allem, 1994; Allem, 1999).

Em trabalhos recentes, tem sido adotada a nomenclatura Manihot esculenta ssp. esculenta para designar a mandioca (Roa, 1996; Olsen \& Schaal, 1999). Outras duas subespécies de Manihot esculenta Crantz seriam as formas selvagens Manihot esculenta ssp. flabellifolia (Pohl) Ciferri e Manihot esculenta ssp. peruviana (Muell. Arg.) Allem.

Esta nomenclatura reflete o atual estágio de entendimento sobre a proximidade genética que existe entre a mandioca e outras espécies do gênero Manihot. Informações detalhadas sobre morfologia e distribuição de populações naturais, além de alguns trabalhos com marcadores moleculares, apoiam a concepção de que no conjunto gênico primário da mandioca estaria $M$. esculenta, com suas três subespécies (Allem, 1987; Allem, 1994; Roa, 1996; Fregene et al., 1997; Roa et al., 1997; Colombo, 1997).

Há menos evidências para definir a composição do cónjunto gênico secundário, mas Allem (1994) aponta as espécies M. glaziovii, M. dichotoma, M. pringlei, M. aescutifolia, M. pilosa, (Allem, 1994). M. pruinosa também é considerada uma espécie próxima de M. esculenta (Olsen \& Schaal, 1999).

Do ponto de vista citogenético, todas as espécies do gênero Manihot, até agora analisadas, possuem 18 cromossomos $(2 \mathrm{n}=36)$, formando 18 bivalentes na primeira metáfase meiótica (Graner, 1935; Perry, 1943; Cruz, 1968; Nassar 1978; Silva Jardim, 1984).

A quantidade de DNA, medida em picogramas, do genoma da mandioca e outras espécies de Manihot está na Tabela 1 (fonte: C. Martinez, Rice Program - CIAT, citada por Hershey, 1994). Awoleye et al. (1994) encontraram um valor médio de $2 \mathrm{C}=1,67$ 
Tabela 1 - Determinação do conteúdo de DNA de espécies de Manihot, por citometria de fluxo

\begin{tabular}{|c|c|c|c|}
\hline \multirow[t]{2}{*}{ Espécie/Acesso } & \multirow[t]{2}{*}{ Origem } & \multicolumn{2}{|c|}{ Quantidade de DNA (pg) } \\
\hline & & Média & Desvio Padrão \\
\hline \multicolumn{4}{|l|}{ M. esculenta } \\
\hline MBra 383 & Brasil & 1,636 & 0.043 \\
\hline MBra 534(*) & Brasil & 1,715 & 0.057 \\
\hline $\mathrm{MCol} 22$ & Colômbia & 1,571 & 0.030 \\
\hline MCol 638 & Colômbia & 1,493 & 0,048 \\
\hline MCol 1522 & Colômbia & 1.494 & 0,027 \\
\hline MCol 1505 & Colômbia & 1.541 & 0.014 \\
\hline MPan 51 & Panamá & 1.524 & 0.040 \\
\hline MPar 101 & Paraguai & 1.532 & 0.066 \\
\hline MPer 436 & Peru & 1.547 & 0.009 \\
\hline MDom 2 & Rep.Dominicana & 1.568 & 0.013 \\
\hline MEcu 41 & Equador & 1.570 & 0.008 \\
\hline MInd 27 & Indonésia & 1,541 & 0,011 \\
\hline MMal 2 & Malásia & 1,477 & 0.014 \\
\hline MMex 17 & México & 1,514 & 0.011 \\
\hline MMex 59 & México & 1,574 & 0,035 \\
\hline MNga 5 & Nigéria & 1.432 & 0,026 \\
\hline MVen 77 & Venezuela & 1.502 & 0,010 \\
\hline Média & & 1,543 & \\
\hline M. esculifolia & México & 1,337 & 0,015 \\
\hline M. chlorosticta & México & 1,466 & 0.070 \\
\hline M. mibricaulus & México & 1.211 & 0,018 \\
\hline $\begin{array}{r}\text { Média } \\
\end{array}$ & & 1,338 & \\
\hline M. anomala & Brasil & 1,551 & 0,006 \\
\hline M. caerulescens & Brasil & 1,544 & 0,035 \\
\hline M. epruinosa & Brasil & 1,734 & 0,122 \\
\hline M. glaziovii & Brasil & 1,687 & 0,008 \\
\hline M. hastatiloba & Brasil & 1,399 & 0,003 \\
\hline M. longipetiolata & Brasil & 1,396 & 0,008 \\
\hline M. pilosa & Brasil & 1,738 & 0,005 \\
\hline M. pseudoglaziovii & Brasil & 1,431 & 0,049 \\
\hline M. tristis & Brasil & 1,571 & 0,002 \\
\hline Média & & 1,562 & \\
\hline M. carthaginensis & Colômbia & 1,764 & 0,042 \\
\hline M. guaranitica & Paraguai & 1,756 & 0,006 \\
\hline
\end{tabular}

$\left(^{*}\right)$ Variedade tradicional, com evidência bioquímica e morfológica de introgressão com espécie selvagem. 
picogramas de DNA para a mandioca, o que seria equivalente a 772 mega pares de bases. É considerado um genoma pequeno, se comparado ao de outras angiospermas.

M. esculenta é tida como alotetraplóide. São consideradas indicações disso: o número alto de cromossomos (para outros gêneros de Euphorbiaceae o valor médio é $\mathrm{n}=$ 11), a morfologia cromossômica (com a existência de 6 tipos cromossômicos em duplicata) e a presença de 3 cromossomos nucleolares (em lugar de 1 ou dois, como freqüentemente se vê em diplóides). O número cromossômico básico sugerido para o gênero é n $=9(4 \mathrm{n}=36)$ (Magoon et al., 1969).

Dados de mapeamento genético e de segregação de alelos, no entanto, não confirmaram definitivamente a hipótese de origem alopoliplóide.

Fregene et al. (1997) publicaram um mapa genético do genoma da mandioca. Foram assinalados no mapa 132 marcas de RFLP, 30 de RAPD, 3 microssatélites e 3 locos isoenzimáticos. Foram identificados 20 grupos de ligação, compreendendo $931,6 \mathrm{cM}$, cerca de $60 \%$ do genoma. Apesar de existir um desvio significativo do número de locos ligados em repulsão em relação ao esperado para um diplóide, não foi possivel concluir sobre a existência ou não de cromossomos homeólogos. Encontraram apenas 5\% de locos duplicados e todos distribuidos aleatoriamente no genoma.

Lefèvre \& Charrier (1993) analisaram dezessete locos usando dez sistemas isoenzimáticos, numa avaliação do polimorfismo de $M$. esculenta, $M$. glaziovii e híbridos espontâneos entre as duas espécies. A análise de segregação para todos os locos indicou herança dissômica.

Chavarriaga-Aguirre et al. (1998) isolaram quatorze microssatélites. Cinco foram associados a pelo menos três grupos de ligação diferentes. Em onze locos havia apenas um ou dois alelos por genoma, como se espera para um genoma diplóide ou completamente diploidizado. Apenas um microssatélite apresentou dois locos e mesmo assim, altamente ligados.

\subsubsection{Diversidade da mandioca: número de variedades}

"A invenção e desenvolvimento da agricultura criaram uma tremenda diversidade entre as espécies escolhidas para domesticação" (Brush et al., 1981, p. 70). 
Essa diversidade se expressa, entre outras coisas, no grande número de variedades que estas espécies apresentam. Isso é válido para plantas diferentes tanto em origem, dispersão ecogeográfica, sistema reprodutivo ou tipo de uso. Contam-se em centenas ou milhares as variedades de arroz, centeio, cevada, trigo, sorgo, milho, feijão, batata, inhame, goiaba, uva, para citar algumas (Cleveland et al., 1994; Struss \& Plieske, 1998; Cattan-Toupace et al., 1998; Brush et al., 1981; Hamon \& Toure, 1990).

Harlan $(1965 ; 1969 ; 1982)$ aponta alguns elementos como possiveis causadores deste acúmulo de variabilidade nas plantas cultivadas: as condiçôes artificiais de manejo que permitem preservar variedades que desapareceriam no ambiente natural; as migrações humanas que promovem o encontro das variedades cultivadas com novas populaçôes de seus parentes selvagens, possibilitando trocas gênicas, em ciclos de diferenciação-hibridação.

Boster $(1984 ; 1985)$ sugere que a existência de grande número de variedades de mandioca se deve a um processo de seleção que envolve além da seleção natural e cultural, um tipo se seleção que ele chamou de "selection for perceptual distinctiveness" (seleção para características que facilitam a distinção entre variedades). Argumenta que para uma cultivar ser mantida como tal, precisa antes de tudo ser distinguida de outras. Só então sua utilidade determinará sua manutenção ou descarte. Normalmente, as características selecionadas assim, não têm uma relação direta com o uso mas com a facilidade de identificação, como por exemplo, cor do pecíolo, formato das folhas, cor do caule, etc. E justamente estas características são descritores usados em análises morfológicas da variabilidade.

Hershey (1994) estimou em 7000 o número de variedades de mandioca.

Rogers \& Fleming (1973) coletaram plantas de 228 populaçôes da Jamaica, Costa Rica, Nicarágua, Bolivia, Peru e do Brasil (Amazonas, Pará, Pernambuco, Minas Gerais e São Paulo). Identificaram 230 cultivares e propuseram um classificação em duas grandes divisões: com raiz rugosa e com raiz lisa, englobando dezenove grupos. Basearam sua classificação em três descritores da raiz, quatro descritores do caule e oito descritores das folhas. 
Boster (1984) encontrou entre os indios Aguaruna Jivaro, que vivem na Amazônia peruana, 700 diferentes nomes de variedades de mandioca. Muitos foram identificados como sinônimos.

Salick et al. (1997) encontraram 204 variedades em 16 comunidades dos indios Amuesha (ou Yanesha, dos Arawak) que vivem nos vales Oxapampa e Palcazy, no Peru. Uma avaliação morfológica agrupou estas variedades em 39 fenótipos bem definidos. $\mathrm{O}$ número médio de variedades cultivada por família foi de 5,9. No entanto o "shaman" Amuesha mantinha 53 variedades, representando 19 diferentes fenótipos.

Kerr \& Clement (1980) calcularam uma média de 22 variedades de mandioca por tribo, entre sete tribos de índios da Amazônia. Listaram nomes e algumas características de 40 variedades encontradas entre os Desâna e de 13 variedades dos Tikúna.

\subsubsection{Diversidade da mandioca: variabilidade genética}

A avaliação da diversidade usando marcadores moleculares tem confirmado a grande variabilidade genética da mandioca mas algumas comparações com espécies selvagens indicam que estas podem conter tanta ou mais variabilidade que a cultivada.

Harlan (1969) já observava que uma das características da evolução das plantas cultivadas é que a distância morfológica, das cultivares e seus ancestrais, é muito maior que as distâncias genéticas e citológicas, o que se poderia inferir da fertilidade dos híbridos e pareamento de seus cromossomos.

Wanyera et al. (1994) usando polimorfismos de 13 locos isoenzimáticos, analisaram a variabilidade genética de 20 plantas de $M$. glaziovii, 20 clones e mandioca e 49 clones da chamada mandioca-de-árvore (do inglês = "tree cassava"), todos coletados na Nigéria. Encontraram maior diversidade entre as mandiocas-de-árvore, seguidas de $M$. glaziovii e menos variabilidade entre os clones de mandioca. A distribuição de alelos e indicadores morfológicos, indicaram que a mandioca de árvore seria um híbrido natural entre as duas espécies.

Olsen \& Schaal (1999) analisando a seqüência de nucleotideos do loco (G3pdh) em 157 plantas coletadas em 27 populações de M. esculenta ssp. flabellifolia, 35 plantas de 6 populações de M. pruinosa e 20 acessos de mandioca, encontraram 28 haplótipos. 
Destes, 6 na mandioca, $23 \mathrm{em} M$. esculenta ssp. flabellifolia e $7 \mathrm{em} \mathrm{M}$. pruinosa. Apesar do desequilibrio numérico da amostragem, observou-se que $M$. pruinosa tinha um número equivalente de haplótipos em relação à mandioca e $M$. esculenta ssp. flabellifolia tinha cerca de três vezes mais haplótipos. A distribuição dos haplótipos entre as populações de $M$. esculenta ssp. flabellifolia não foi igual, havendo maior diversidade entre as populações localizadas em MT, RO e AC do que em TO e GO

Roa (1996; Roa et al., 1997) avaliou diversidade de Manihot usando 304 bandas de AFLP. Encontrou maior diversidade para 27 acessos do grupo M. esculenta ssp. flabellifolia e $M$. esculenta ssp. peruviana, a seguir para 25 acessos de $M$. carthaginensis: em terceiro lugar vieram 38 acessos de mandioca.

Roa et al. (no prelo), para 10 locos de microssatélites, encontraram índices de heterozigosidade esperada de $H_{c}=0,43$ para 38 acessos de mandioca, $H_{e}=0,31$ para 26 acessos de $M$. carthaginensis, $\mathrm{H}_{\mathrm{e}}=0,54$ para 16 acessos de $M$. esculenta ssp. flabellifolia e $\mathrm{H}_{c}=0,32$ para $M$. esculenta ssp. perwviana. Os índices de heterozigosidade observada $\left(\mathrm{H}_{0}\right)$ foram $\mathrm{H}_{\mathrm{o}}=0,63, \mathrm{H}_{\mathrm{o}}=0,12, \mathrm{H}_{\mathrm{o}}=0,44$ e $\mathrm{H}_{\mathrm{o}}=0,31$ respectivamente.

Lefèvre \& Charrier (1993) encontraram índices médios de heterozigozidade (Nei, 1978) para 17 locos polimórficos de isoenzimas de: $H=0,225$ em 365 acessos de mandioca e $\mathrm{H}=0,252$ em 109 acessos de $M$. glaziovii. Os acessos eram, em sua grande maioria, oriundos da África.

Alguns outros estudos ajudam a quantificar a variabilidade genética da mandioca.

Colombo (1997; Colombo \& Valle 1998), usando bandas polimórficas de RAPD, encontrou um valor médio de similaridade (Jaccard) de $\mathrm{S}=0,63$ para 10 acessos de $M$. esculenta ssp. flabellifolia e $\mathrm{S}=0,57$ para 6 acessos de $M$. esculenta ssp. perwiana. Para o conjunto de 16 plantas o valor médio foi $S=0,61$, variando de $S=0,38$ a $S=$ 0,81 . Para 20 acessos de mandioca da coleção mundial o valor médio foi $S=0,66$, variando de $S=0,51$ a $S=0,84$. Para 13 variedades tradicionais da localidade de Santa Isabel, na Amazônia, o valor médio foi de $S=0,70$, com mínimo de $S=0,55$ e máximo de $\mathrm{S}=0,82$. Para as mesmas plantas, usando bandas polimórficas de AFLP, encontrou média de $S=0,64$ para o grupo flabellifolia/peruviana, mínima de $S=0,33$ e máxima de $S$ 
$=0,84$. Para a coleção mundial: média de $S=0,72$, mínima de $S=0,56$ e máxima de $S=$ 0,88. Para Santa Isabel: média de $S=0,71$, mínima de $S=0,52$ e máxima de $S=0,79$.

Carvalho et al. (1999) relataram a avaliação da diversidade genética de 94 acessos de mandioca usando três marcadores morfológicos e 96 bandas polimórficas de RAPD. Estimaram a diversidade pelo valor $\pi$ (índice de diversidade de nucleotideos). Os índices variaram de $\pi=0,326 \%$ a $\pi=2,779 \%$. Os agrupamentos feitos por UPGMA e baseados nos quocientes de similaridade de Jaccard foram diferentes para os dois tipos de marcador, com uma correlação entre agrupamentos de $\mathrm{r}=0,007$.

Carvalho et al. (1998), usando RAPD, compararam a diversidade de 59 acessos de mandioca de uma coleção mundial com variedades brasileiras de sete diferentes habitats agroecológicos. Encontraram maior diversidade genética entre as variedades brasileiras que da coleção mundial. Quanto à diversidade as plantas oriundas de Caatinga (CA) e Trópico Úmido (TU) apresentaram maiores índices, a seguir as de Cerrado (CR) e por fim as de Sub-Trópico (ST), Litoral (LI) e Semi-Árido (SA). A menor divergência, das variedades brasileiras com plantas de outras regiões, foi com Cuba e a maior com a Malásia.

Carvalho et al. (1998) usaram RAPD e PCR com iniciadores formados por microssatélites para examinar a distribuição da diversidade entre acessos de mandioca dos sete habitats agroecológicos definidos no parágrafo anterior. O nível de polimorfismo variou conforme o tipo de marcador, sendo maior para RAPD. As variedades foram melhor agrupadas, em função da origem agroecológica, a partir dos microssatélites. A média de diversidade de nucleotídeos foi $0,3 \%$ maior para RAPD.

Elias et al. (1998) estudaram diversidade de mandioca em uma aldeia Macuxi, na Guiana Inglesa. Foram identificadas pelos agricultores 76 diferentes variedades. Um ensaio comparativo, usando os mesmos marcadores, revelou que as variedades Macuxi não estão bem representadas na coleção mundial mantida no CIAT.

Além da mandioca contar com grande número de variedades, existe, também, diversidade genética dentro das variedades. Apesar do plantio da mandioca ser feito por estacas, gerando clones, uma variedade por ser composta por dois ou mais grupos de clones diferentes. 
Peroni (1998), estudando taxonomia "folk" de produtores, em roças de agricultura tradicional, em áreas de Mata Atlântica do Estado de São Paulo, usou 10 sistemas isoenzimáticos para detectar diversidade genética intravarietal em mandioca. Concluiu que os agricultores diferenciam coerentemente as variedades de mandioca através da morfologia. Entretanto, não distinguem genótipos diferentes "dentro" das etnovariedades, quando as plantas apresentam grande semelhança morfológica. Portanto, uma variedade poderia ser considerada como uma "familia" de genótipos.

Mkumbira et al. (1998) usaram oito microssatélites para avaliar distâncias genéticas entre 10 variedades de mandioca do Malawi. Analisaram 25 plantas de cada variedade, coletadas em pelo menos 10 diferentes áreas de cultivo. Concluiram que algumas variedades eram heterogêneas, geneticamente, e que isso se deveria à dificuldade de distinguir morfologicamente as plantas de diferentes genótipos.

Elias et al. (1998), para avaliar preliminarmente a existência de variação intravarietal em mandioca, usaram uma amostra de 30 variedades dos índios Macuxi, 5 plantas de cada. E função de polimorfismos do tipo AFLP, 74 diferentes genótipos foram encontrados.

\subsubsection{Geração, manutenção e perda de variabilidade genética da mandioca}

Para a maioria das plantas cultivadas, a grande diversidade genética que chegou até os tempos modernos está associada a modos de cultivo tradicionais.

Variabilidade de mandioca especialmente grande é encontrada, ainda, entre povos indígenas no continente americano, com destaque para a Bacia Amazônica. A preservação desta variabilidade está relacionada ao tipo de cultura agrícola prevalecente entre estes povos (Kerr \& Clement, 1980; Salick et al., 1987; Boster, 1985).

No Brasil, o tipo de agricultura praticado na maior parte destas tribos e, com diferentes graus de alteração, entre caiçaras e outros grupos de agricultores familiares tradicionais, é a agricultura de coivara, também chamada de plantio no toco, agricultura de corte e queima ou itinerante.

Os procedimentos básicos na agricultura de coivara são: derrubada de uma pequena área de vegetação natural (mata, cerrado, capoeira). Queima controlada. Plantio 
de várias espécies com numerosas variedades entre os restos da derrubada e queimada. Eliminação moderada de plantas invasoras. Colheita por um periodo extenso. Replantio por um a três anos. Abandono da área para um período de recomposição expontânea da vegetação natural. Possivel retorno à mesma área após 5 a 25 anos de pousio (Posey, 1984).

Uma caracteristica associada à agricultura de coivara em regiões tropicais é que em várias das espécies cultivadas nestas roças, a parte da planta aproveitada para consumo humano são as raizes ou tubérculos. É o caso da mandioca, do cará, inhame, batata-doce e da taioba. Estas plantas são propagadas vegetativamente, criando-se populações clonais, mas não perderam sua capacidade de reprodução sexual, gerando esporadicamente individuos recombinantes (Peroni, 1998; Martins, 1994a).

Um modelo foi proposto por Cury (1993) e Paulo Sodero Martins (comunicação pessoal) relacionando todos os elementos envolvidos na dinâmica evolutiva da mandioca dentro deste tipo de sistema agrícola, que leva à geração e manutenção da considerável variabilidade genética encontrada nesta espécie. A Figura 1 mostra uma representação gráfica deste modelo e a Tabela 2 relaciona diferentes aspectos do manejo agrícola tradicional com eventos associados à dinâmica evolutiva da mandioca.

Desequilibrios no sistema agrícola tradicional podem levar a uma redução na variabilidade das culturas (Cleveland et al., 1994; Brush, 1991).

Sambatti (1998) descreveu o processo de redução da variabilidade de mandioca em roças de agricultores tradicionais residentes na área que se converteu em Parque Estadual da Serra do Mar. A legislação ambiental impede os agricultores de abrirem novas áreas para plantio. Com isso, um elemento chave da agricultura de coivara: o pousio, passou a ser impraticável. Nas roças já abertas, houve uma rápida perda de fertilidade do solo e a maioria das variedades tradicionais de mandioca plantadas na região mostraramse improdutivas nestas condições. Foram substituídas por uma única variedade que se mostrou mais resistente às condições de baixíssima fertilidade dos solos. 


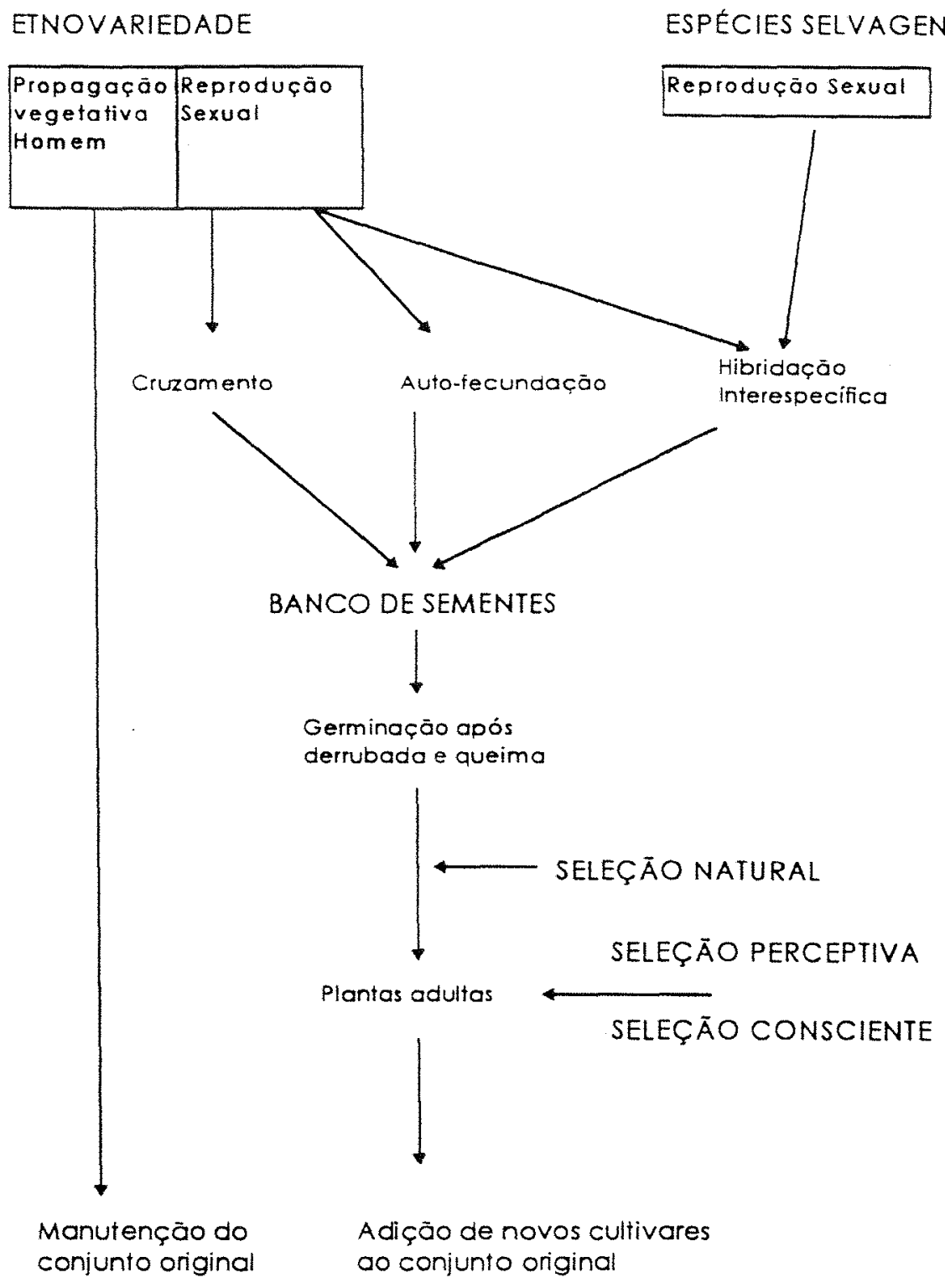

Figura 1 - Modelo de Dinâmica Evolutiva da Mandioca*

* Segundo Paulo Sodero Martins - comunicação pessoal, modificado a partir de Cury (1993) 
Abertura da roça

Plantio da roça

Plantio de diferentes espécies

Plantio de diferentes variedades

Controle brando de colonizadoras

Ausência de colheita de sementes

Retorno às áreas de roças antigas

Propagação vegetativa
Perturbação estimulando

colonização

Estabelecimento de população

com limites definidos

(unidade evolutiva)

Habilidade de combinação

ecológica

Favorecimento de intercruzamento (hibridações)

Hibridação introgressiva

Dispersão natural e formação de banco de sementes

Germinação de sementes do banco

Manutenção dos genótipos

originais, fixação de mutantes

Figura 1A - Relação entre manejo tradicional e eventos de dinâmica evolutiva da mandioca ${ }^{*}$

* Segundo Paulo Sodero Martins - comunicação pessoal 


\subsubsection{Mandioca brava, aipim e macaxeira}

A mandioca brava, ou simplesmente mandioca, é claramente diferenciada pelos agricultores tradicionais, sobretudo os índios, do aipim ou macaxeira. A mandioca brava, necessariamente, passa por várias etapas de processamento antes de ser consumida e os aipins e macaxeiras ou mandiocas de mesa, podem ser simplesmente cozidos ou assados.

Vários levantamentos dão conta desta divisão entre mandioca brava, aipim e macaxeira. Para citar alguns:

Gabriel Soares de Souza, no seu "Tratado descritivo do Brasil em 1587" (citado por Cury, 1993) listou seis variedades de mandioca e oito variedades de aipim encontradas entre os indios. Kerr \& Clement (1980) relacionaram 39 cultivares de mandioca e 1 macaxeira encontradas entre os indios Desâna da Amazônia e 6 variedades de mandioca e 7 macaxeiras entre os Tikúna. Dufour \& Wilson (1996) encontraram cerca de 100 variedades de mandioca entre os indios Tukâno na Amazônia colombiana sendo a maior parte bravas (chamadas "kii") e apenas umas poucas macaxeiras (chamadas "makasera"), possivelmente introduzidas por seringueiros oriundos do Brasil.

Os critérios para essa diferenciação não estão bem estabelecidos mas, de modo geral, haveria altos teores de glucosideos cianogênicos, e conseqüente toxidez, na polpa das raizes de mandiocas bravas, enquanto as macaxeiras e aipins teriam baixos teores destes glucosídeos. Variedades com teores de HCN menores que $50 \mathrm{mg}$ por $\mathrm{kg}$ de raiz descascada (peso fresco) seriam inócuas, com teores entre 50 e $100 \mathrm{mg} / \mathrm{kg}$ medianamente tóxicas e acima de $100 \mathrm{mg} / \mathrm{kg}$ altamente tóxicas (McKey \& Beckerman, 1993; Dufour, 1988).

Alguns autores correlacionam a presença de glucosideos cianogênicos ao sabor amargo e fazem uma divisão entre mandiocas amargas ou doces, ou em inglês: "bitter" e "sweet" ou "cool" (Renvoize, 1972; Mkumbira et al., 1989a, 1998b; Rosling, 1996; Nye, 1990; Dufour \& Wilson, 1996; Emperaire et al., 1998; McKey \& Beckerman, 1993; Pereira \& Pinto, 1962; Pereira et al., 1965). 
Renvoize (1972), em sua revisão sobre origem da mandioca, apresentou um mapa (redesenhado a partir de Nordenskiöld ${ }^{*}$ ) em que se observam diferentes distribuições geográficas de mandiocas "amargas e doces" (Figura 2). Em algumas regiões predominam as macaxeiras, em outras as mandiocas bravas e em outras os dois tipos coexistiriam.

Mckey \& Beckerman (1993) sugeriram que o uso preferencial de um tipo ou outro, como alimento básico, estaria associado a um conjunto de aspectos culturais das sociedades indigenas nas terras baixas do continente sul americano.

Esta divisão se refletiu também na classificação botânica da mandioca, antes que a denominação 1. esculenta tivesse aceitação geral. Foram propostas: Manihot utilissima Pohl para mandiocas bravas e M. dulcis, M. aipi ou M. palmata para as mandiocas mansas (Rogers, 1965).

Rogers \& Fleming (1973), porém, não usaram esta característica em sua classificação das variedades de mandioca porque testes de conteúdo de HCN mostraram que existe um continuum de concentrações não sendo possivel definir uma linha divisória entre mandiocas bravas e mansas para este caráter. Portanto, esta característica não teria valor taxonômico.

Normanha (1956, p. 14) já dizia que:

"Nâo sabemos de características botânicas ligadas à presença de maior ou menor quantidade de HCN em plantas de mandioca, em outras palavras, não podemos identificar uma variedade de mandioca, como sendo brava ou não, pela verificação das características morfológicas das plantas".

Também relata que a variação do teor de HCN não depende apenas da variedade mas também da idade das plantas (quanto mais novas maiores os teores) e de condições ambientais como solo, clima e altitude.

Mkumbira et al. (1998a), analisando variedades "bitter" e "cool" de mandioca de Malawi, também notaram diferenças nos teores de glucosídeos cianogênicos em função de:

\footnotetext{
* Noedenskiöld, E. The ethnography of South America seen from Mojos in Bolivia. Comparative

Ethmological Studies, 3. Gothenburg, 1924
} 


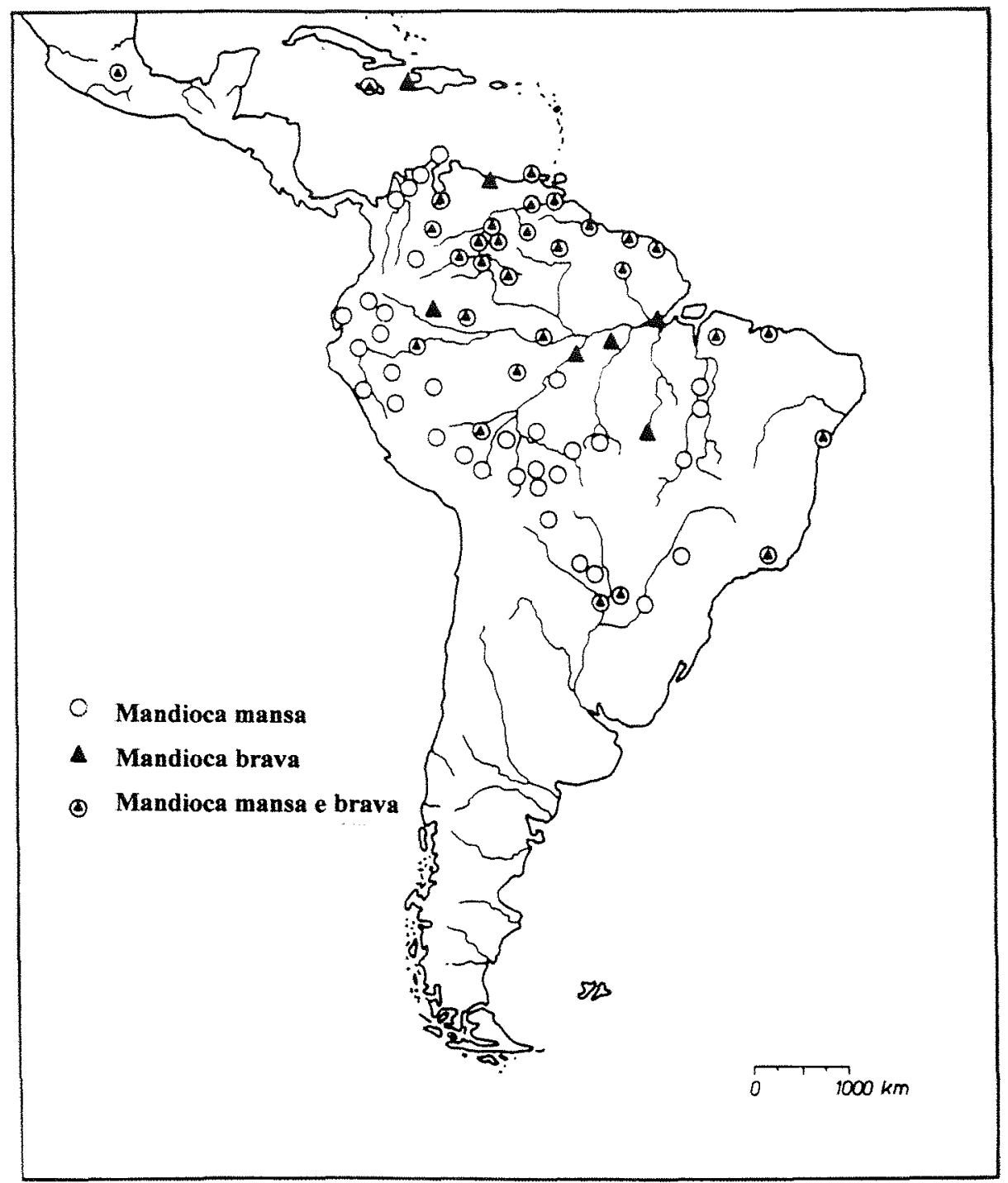

Figura 2 - Distribuição histórica de variedades bravas e mansas de mandioca*

\footnotetext{
* Segundo Renvoize ( 1972) redesenhado a partir de Nordenskiöld (ver texto).
} 
posição topográfica das áreas de plantio, presença de formigueiros e diferentes teores de fósforo no solo.

Correia (1947) analisou o conteúdo de HCN de 20 variedades de mandioca incluindo as mais comuns do Estado de São Paulo e algumas do Estado da Bahia. Encontrou teores sempre mais altos na entrecasca do que na polpa das raizes. As mandiocas bravas tinham maior conteúdo de $\mathrm{HCN}$ do que as mansas. A fervura em água pelo tempo usualmente usado no cozimento da mandioca foi suficiente para eliminar quase a totalidade do HCN da polpa. Sugeriu que talvez existisse outro princípio ativo nas raízes, responsável por casos de envenenamento. Citou Zehntner*, que teria isolado uma substância das raizes frescas a qual, em doses minimas, causaria perturbações gerais no sistema nervoso dos animais. Além da toxidez, várias das mandiocas bravas apresentavam sabor amargo, mesmo cozidas, e possivelmente alto teor de fibras.

Pereira \& Pinto (1962; Pereira et al., 1965) desenvolveram uma metodologia para a diferenciação das mandiocas amargosas e tóxicas das doces, mansas, próprias para consumo de mesa. Segundo estes autores, os teores mais elevados de HCN estão nitidamente associados ao paladar mais amargo dessas raizes. Os testes de paladar foram feitos com a polpa das raizes cruas por provadores especialmente treinados.

Sinha \& Nair (1968) avaliaram 33 variedades de mandioca da Índia quanto a sabor e teor de HCN nas raizes. Apesar da tendência geral de mandiocas amargas terem teores de HCN mais altos que as não amarga e as doces, encontraram várias exceções. Concluíram que o teor de HCN pode estar relacionado ao sabor amargo mas não seria o único fator e que, possivelmente, a presença de maior teor de açúcares, responsáveis pelo sabor adocicado, poderia encobrir o sabor amargo associado ao HCN. Não descartaram a hipótese de que outra substância poderia contribuir para o sabor amargo.

Neste mesmo estudo, mostraram que os teores de HCN variam com a idade da planta: no período entre sete meses e 13 meses de idade, que é a época normal de coIheita das variedades estudadas, houve um aumento entre o sétimo e o nono meses e depois um acentuado decréscimo até os 13 meses.

\footnotetext{
* Zehntner, L. In: Estudo sobre algumas variedades de mandiocas brasileiras. Sociedade Nacional de Agricultura. Rio de Janeiro, 1919.
} 
Cury (1998) não encontrou uma correlação clara entre potencial cianogênico (e teores de ácido cianídrico livre em folhas, entrecasca e polpa das raizes) e a classificação em mandioca brava e macaxeira ou aipim. Foram analisadas 56 plantas da região amazônica e do litoral sul do Estado de São Paulo. Algumas das macaxeiras e aipins estavam entre as plantas com maior potencial cianogênico.

Mkumbira et al. (1998b) analisaram glicosideos cianogênicos totais de 105 variedades de mandioca de Malawi e também encontraram teores altos e baixos tanto para variedades "amargas" como "doces" ("cool").

Quanto à origem dos dois tipos de mandioca a partir de ancestrais selvagens, McKey \& Beckerman (1993) resumem as possibilidades em quatro: 1) a ordem seria de uma espécie selvagem não amarga, para cultivares não amargas e depois para cultivares amargas; 2) ou de uma espécie selvagem amarga, para cultivares amargas e depois para cultivares não amargas; 3) uma espécie selvagem amarga dando origem às cultivares amargas e uma espécie selvagem não amarga dando origem às cultivares não amargas; 4) ancestrais desconhecidos e possivelmente com toxicidade intermediária, dando origem aos dois tipos de cultivares. Discutem a questão em termos das pressões seletivas naturais e artificiais que teriam atuado neste processo e consideram as evidências atualmente disponiveis insuficientes para qualquer definição.

Estudo recentes mostraram que conjuntos de caracteres morfológicos ou de marcadores de DNA podem distinguir mandiocas bravas de mandiocas mansas.

Colombo et al. (1998), usando RAPD, marcadores morfológicos e análise de componentes principais (PCoA), encontraram uma separação clara entre 7 macaxeiras e dois outros grupos de mandiocas bravas, todas originárias do Brasil.

Mkumbira et al. (1998a), usando microssatélites e PCoA, mostraram uma boa separação entre genótipos de mandiocas amargas e "cool".

\subsection{Marcadores de DNA}

A história da genética está ligada ao uso de marcadores desde seu nascimento, com o trabalho de Gregor Mendel, apresentado em 1865. Em seu famoso estudo com 
ervilhas, Mendel usou marcas morfológicas para investigar o modo de transmissão dos caracteres para os descendentes (Mendel, 1948).

Os descritores morfológicos também foram a principal ferramenta usada no gigantesco esforço realizado por naturalistas para identificação, descrição e classificação dos seres vivos.

A relação entre essa grande diversidade biológica e a diversidade genética, propriamente, passou a ser melhor explorada com o desenvolvimento de técnicas bioquímicas e de genética molecular.

Desde a identificação dos cromossomos e depois do DNA (Avery et al., 1944), como sendo os portadores e transmissores primários da informação genética, a crescente compreensão dos mecanismos bioquímicos e ambientais que atuam na expressão desta informação genética evidenciaram duas tendências opostas: a diversidade, no nível molecular, pode ser ainda maior que a diversidade morfológica, entre individuos de uma mesma espécie.

Por outro lado, existe uma impressionante conservação de processos biológicos no nível celular e mesmo conservação de seqüências de nucleotídeos em alguns genes, entre espécies morfologicamente tão contrastantes e tão distantes do ponto de vista evolutivo como leveduras, plantas superiores e mamíferos.

Vários aspectos surpreendentes da organização dos genomas de organismos superiores estão sendo desvendados. Um deles, conhecido comó o paradoxo do valor $\mathrm{C}$, é que a proporção do DNA diretamente envolvido na codificação de proteínas é pequena em relação ao total de DNA que compõe os genomas.

Em angiospermas, estimando o número de genes em 15.000, que estariam contidos em cerca de 18 milhões de pares de bases (Mb) (Flavell, 1980; Goldberg et al., 1978; Kiper et al., 1979), a proporção de DNA não codificador estaria entre $91 \%$ em Arabidopsis thaliana $(\mathrm{C}=\mathrm{n}=0,2$ pg de DNA) e mais de $99 \%$ em Viscum album $\mathrm{L}$. (C $=n=90,8$ pg de DNA) (Bennett \& Leitch, 1995).

A maior parte deste DNA não codificador é formada por seqüências repetitivas de várias naturezas (Flavell, 1980), entre elas, microssatélites (Litt \& Luty, 1989). Grande parte das mutações ocorridas neste DNA não codificador é seletivamente neutra, 
o que determina um padrão de evolução diferente, e freqüentemente mais rápida, da evolução fenotípica.

Graças ao desenvolvimento recente de algumas técnicas de genética molecular, variações nas diferentes seqüências de nucleotídeos do DNA podem ser detectadas e usadas como marcadores em estudos de filogenia e genética de populações, possibilitando maior precisão do que os marcadores morfológicos.

\subsubsection{RAPD}

\section{Descrição da técnica de RAPD}

A técnica denominada RAPD, para deteç̧ão de polimorfismo no DNA, foi inicialmente descrita por dois grupos de pesquisadores (Williams et al., 1990 e Welsh \& McClelland, 1990) recebendo denominações diferentes: RAPD (do inglês "Random Amplified Polymorphic DNA" = DNA polimórfico amplificado aleatoriamente) e APPCR (do inglês "Arbitrarily Primed Polymarase Chain Reaction" = reação em cadeia de polimerase iniciada arbitrariamente).

As duas versões são diferentes nos detalhes técnicos mas iguais no seu fundamento. Baseiam-se em amplificação de fragmentos de DNA por PCR, seguida de separação dos fragmentos amplificados, segundo seu tamanho, por meio de eletroforese em meio semisólido (normalmente gel de agarose) e sua visualização (normalmente por coloração com brometo de etídeo e exposição a luz ultravioleta).

Neste tipo de PCR, são amplificados fragmentos de DNA não identificados $a$ priori. Para isso são usados como iniciadores ("primers"), oligonucleotideos (freqüentemente decâmeros) de composição arbitrária, que podem ter homologia total ou parcial com uma ou mais regiões no genoma. O seu pareamento com o DNA molde direciona a ação da DNA polimerase para o trecho contiguo à região de homologia.

\section{Reprodutibilidade dos resultados de RAPD}

Um dos problemas no uso desta técnica são as alterações dos resultados em função das condições do PCR. Foram descritos vários fatores que afetam o padrão de bandas: concentração de $\mathrm{MgCl}_{2}$, de DNA molde e de nucleotídeos na solução; temperatura 
de anelamento; tipo de polimerase; tipo de termociclador; composição e comprimento dos iniciadores.

Williams et al. (1993) realizaram um estudo detalhado de todos estes fatores. Demonstraram que há maior ou menor interferência de cada fator nos padrões de bandas obtidos e que é necessário observar certos limites de variação para cada fator de modo a conseguir reprodutibilidade nos resultados.

Mizukami et al. (1998) obtiveram diferentes padrões de bandas de RAPD usando 5 diferentes protocolos para extração de DNA da alga Porpyra yezoensis. Quando o DNA foi purificado em gradiente de $\mathrm{CsCl}$, obtiveram alta reprodutibilidade. Sugerem que a presença de impurezas na solução de DNA molde pode afetar os resultados de RAPD.

Heun et al. (1994) testaram a reprodutibilidade de RAPD realizando duplicaçôes da amplificação para 6 a 24 acessos de Avena sterilis, com 8 diferentes iniciadores. Em média, 97\% das definições de presença e ausência de bandas se repetiram na duplicata.

Colombo et al. (1998), testando o efeito de diferentes concentrações de DNA de mandioca, mostraram que para concentrações entre 1 e 128 ng de DNA molde os padrões de bandas de RAPD foram iguais. No entanto, foram detectadas alterações devidas ao uso de diferentes termocicladores.

\section{Tipos de polimorfismo detectados e natureza do DNA amplificado por RAPD}

Dois tipos de polimorfismo podem ser detectados por esse método: alterações suficientemente grandes na região de homologia do iniciador para que não haja mais pareamento ou o pareamento seja muito dificultado. Neste caso não haverá amplificação desta região, ou a amplificação será insuficiente para uma boa visualização da banda resultante (Williams et al., 1990).

O outro tipo de polimorfismo detectado é a alteração do comprimento da região amplificada, por duplicação, inserção ou eliminação de nucleotídeos, resultando no aparecimento de bandas com diferente comportamento eletroforético (Quiros et al., 1995).

Mutações de ponto dentro da região amplificada, que nâo impliquem em mudança de tamanho dos fragmentos produzidos pela polimerase, não podem ser detectadas. 
Também não é possivel distinguir fragmentos oriundos da amplificação de diferentes regiões, se tiverem o mesmo comprimento.

Como, via de regra, são amplificadas simultaneamente mais de uma região do genoma, não se faz distinção entre: bandas provenientes de um mesmo loco com diferentes alelos e bandas provenientes de diferentes locos. Isso leva ao uso do RAPD como marcador dominante. (Williams et al., 1990; Williams et al., 1993; Chalmers et al., 1992)

Em relação à homologia entre fragmentos de mesmo comportamento eletroforético existem alguns trabalhos com resultados distintos:

Svitashev et al. (1998), numa analise do gênero Elynus da tribo Triticeae (Poacea), selecionaram de três a quatro bandas de RAPD específicas de cada um dos 5 genomas que compõem o gênero. Um teste de hibridação dos fragmentos presentes nestas bandas, demonstrarou que nenhum deles era realmente específico do genoma mas sim constataram que ocorria hibridação cruzada com DNA de outras espécies. Citando Wang $\&$ Zhang (1996), os autores sugerem que a aparente especificidade das marcas em relação aos genomas se devia a alterações nas seqüências de pareamento com os iniciadores e não às seqüências internas dos fragmentos amplificados.

Williams et al. (1993) encontraram, num teste de hibridação, 10\% de bandas que co-migravam no gel mas não apresentavam homologia de seqüência, entre várias espécies de Glycine.

Thormann et al. (1994) sugeriram que diferenças entre 2 dendrogramas, com 18 acessos de Brasisica, feitos com base em polimorfismos de RFLP e RAPD, poderiam dever-se a falsa homologia entre fragmentos nos géis de RAPD. Testaram, por hibridação, a homologia de 15 bandas e constaram que três delas $(20 \%)$ não hibridaram com bandas de mesma posição relativa no gel e que esta falta de homologia só foi encontrada entre espécies diferentes e não entre acessos de uma mesma espécie. Também mostraram, reduzindo a estringência das condiçôes de hibridação, que havia homologia apenas parcial entre bandas de peso molecular equivalente.

Adams \& Rieseberg (1998) mostraram que falsas homologias, de até $20 \%$ das bandas de RAPD, aumentaram os valores absolutos das estimativas de similaridade mas 
não alteraram a similaridade relativa do conjunto, determinada por métodos de ordenação do tipo PCO. A análise foi feita com dados de RAPD testados independentemente: para três espécies do gênero Heliantus e para seis espécies do gênero Brassica.

Quanto ao tipo de DNA amplificado por RAPD:

Williams et al. (1993) mostraram, por teste de hibridação com 6 variedades de soja, que fragmentos amplificados por RAPD podem ser oriundos de seqüencias de cópia única, medianamente repetitivas ou altamente repetitivas.

Williams et al. (1990), Echt et al. (1992) e Devos \& Gale (1992) encontraram fragmentos amplificados por RAPD de regiões repetitivas, enquanto que Marillia \& Scoles, (1996) obtiveram amplificaçào de DNA de cópia única.

Svitashev et al. (1998), avaliando a intensidade de hibridação de fragmentos amplificados por RAPD, com DNA total clivado por enzimas de restrição, concluiram que as bandas de RAPD podem derivar de sequeencias únicas ou com poucas cópias no genoma.

Cifarelli et al. (1995) mostraram que bandas de RAPD podem conter microssatélites, em Beta vulgaris L., Helianthus annuus L. e Olea europaea L.

Richardson et al. (1995), num estudo de espécies do gênero Dioscorea, mostraram que além de algumas bandas de RAPD, visualizadas normalmente pela coloração com brometo de etídeo, também bandas muito fracas, detectáveis somente por hibridação e visualização por autoradiografia, continham microssatélites.

Quiros et al. (1995) seqüenciaram duas bandas de RAPD (com 1154 e 1116 pb) que tinham um padrão de segregação codominante em Brassica nigra. A diferença de tamanho devia-se principalmente a uma deleção interna de 41 pb. Além disso encontraram algumas deleções menores de um a três pares de bases, incluindo parte de um microssatélite de trinucleotídeos CTT. Além destas deleções, observaram várias substituições sendo 16 transições e 9 transversões.

\section{Distribuição das marcas geradas por RAPD nos genomas}

O mapeamento de marcas geradas por RAPD, em várias espécies de plantas, tem apontado uma ampla dispersão dentro dos genomas, sem indicação de agrupamento de 
marcas em regiões específicas (Al-Janabi et al., 1993; Kurtovskii et al., 1998; Agrama et al., 1997; Barreneche et al. 1998; Cho et al., 1998; Dirlewanger, 1998; Laucou, 1998; Sharon et al., 1997; Spada et al., 1998).

Fregene et al. (1997) publicaram um mapa genético de Manihot esculenta Crantz com 132 marcas de RFLP, 30 de RAPD, 3 microssatélites e 3 isoenzimas. As marcas de RAPD ficaram distribuidas em 15 dos 20 grupos de ligação definidos pelo conjunto das marcas. Não se observou nenhum direcionamento especifico das 30 marcas.

\subsubsection{AFLP}

\section{Descrição da técnica de AFLP}

A técnica denominada AFLP, para detectar polimorfismos de DNA, foi inicialmente descrita por Van Eck et al. (1995) e Vos et al. (1995). Assim como na técnica de RAPD, trata-se de amplificação, por PCR, de fragmentos aleatórios do genoma (Figura 3).

Para aumentar a quantidade de fragmentos amplificados em uma única reação, realiza-se uma clivagem do DNA com duas enzimas de restrição. Enzimas que reconhecem muitos sítios no genoma vão gerar maior número de fragmentos que serão depois amplificados. Enzimas que reconhecem sítios raros vão gerar menor número de fragmentos para amplifícação.

Todos os fragmentos produzidos pela clivagem têm extremidades iguais e conhecidas. A estas extremidades se acrescenta um pequeno fragmento de DNA de fita dupla, com cerca de 15 pares de bases, chamado adaptador. A ligação dos adaptadores aos fragmentos é feita por uma enzima, normalmente a ligase T4. A função dos adaptadores é propiciar o pareamento dos iniciadores com os fragmentos de DNA que servirão de molde, na reação de PCR. As seqüências de nucleotídeos dos adaptadores são complementares às dos iniciadores.

Depois de feita a clivagem e a ligação dos adaptadores, os fragmentos de DNA são amplificados por PCR. Os iniciadores usados nesta reação podem estar marcados para permitir a visualização dos fragmentos amplificados. Os processos mais utilizados 


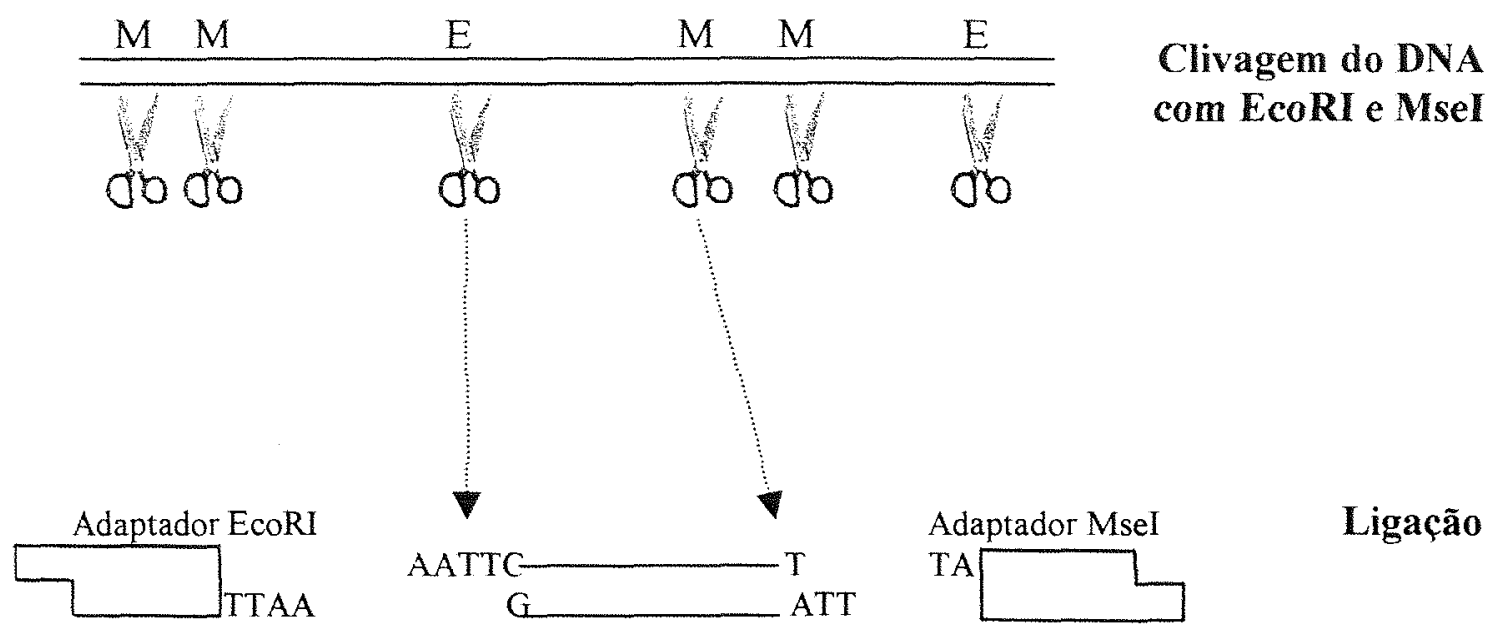

Iniciador EcoRI + 1

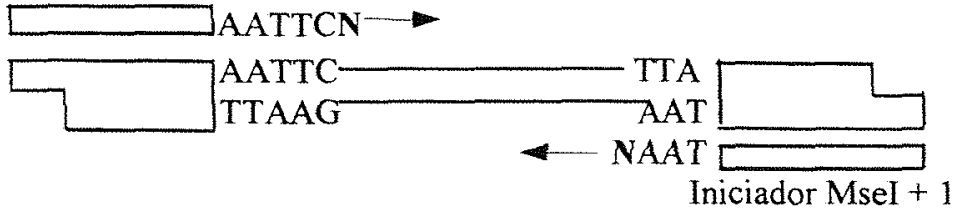

Pré-amplificação

Iniciador EcoRI +3

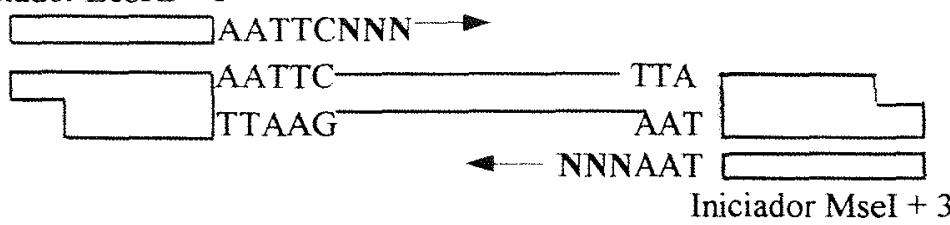

Amplificação

Seletiva

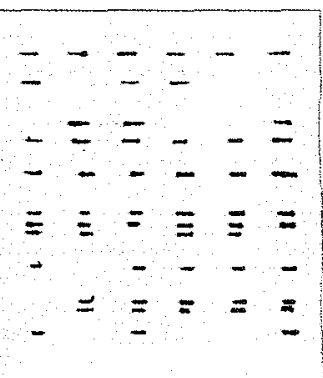


são radioatividade e fluorescência. Também é possivel usar iniciadores não marcados e fazer uma coloração posterior do gel com nitrato de prata.

Normalmente a amplificação é feita em duas etapas. Na primeira, chamada de pré-amplificação ou PCR +1 , a reação de $\mathrm{PCR}$ é feita com iniciadores que, além da seqüência homóloga à dos adaptadores, possuem um nucleotideo a mais, avançando para o interior do fragmento a ser amplificado.

Numa segunda rodada de amplificação, chamada amplificação seletiva ou PCR +2 (ou PCR + 3), os iniciadores usados têm dois ou três nucleotídeos a mais que a seqüência do adaptador. A finalidade destes nucleotídeos excedentes é limitar o número de fragmentos a amplificar, para que os padrões de bandas produzidos sejam passiveis de uma boa separação e visualização. Somente aqueles que apresentarem homologia, além da região adaptadora, também com estes nucleotídeos excedentes, serão amplificados.

Observa-se, então, que a diferença fundamental entre as técnicas de RAPD e AFLP é que: na primeira, a seleção das regiões que serão amplificadas é feita em função de homologia com os oligonucleotídeos usados como iniciadores. Já na segunda técnica, a seleção primária das regiões que serão amplificadas é feita em função da existência de sítios reconhecidos por enzimas de restrição. A freqüencia de sítios de restrição, com quatro ou cinco pares de bases é muito maior que dos sítios homólogos aos iniciadores de RAPD, com dez pares de bases. Por isso detectam-se mais polimorfismos por reação de PCR pela técnica de AFLP do que de RAPD.

\section{Distribuição das marcas geradas por AFLP, nos genomas}

Apesar do pouco tempo de uso desta técnica, já existem alguns mapas genéticos de plantas com a localização de marcas de AFLP. Spada et al. (1998) mapearam 18 bandas no genoma de Asparagus officinalis; Virk et al. (1998) incorporam 150 marcas de AFLP a um mapa baseado em RFLP de Oryza sativa; Cho et al., (1998) prepararam um mapa integrado com marcas de AFLP, SSLP e RFLP também em Oryza sativa. Todos estes trabalhos indicam que há uma amostragem razoável dos genomas, com as marcas de AFLP sendo distribuídas por todos os grupos de ligação. 
Law et al. (1998), analisando estatisticamente a distribuição de 90 bandas polimórficas de AFLP entre 55 variedades de trigo, demonstraram, mesmo sem mapeá-las, que elas não estavam significativamente agrupadas no genoma e que podiam ser usadas com razoável segurança na discriminação entre as variedades.

\subsubsection{Microssatélites}

\section{O que são microssatélites}

Microssatélites ou SSRs (do inglês "simple sequence repeats" = repetiçôes de sequências simples) ou STRs (do inglês "short tandem repeats" = repetições curtas em tandem) são trechos do genoma compostos pela repetição de uma seqüência curta e simples de nucleotideos. As seqüências repetidas que compôem os microssatélites normalmente são mono, di, tri e tetra nucleotídeos (Tautz et al., 1986; Weber \& May, 1989).

As característica dos microssatélites, que favoreceram seu uso como marcadores de DNA, são: sua alta freqüência e ampla dispersão pelos genomas e a alta taxa de mutação a que estão sujeitos, resultando em grande variabilidade.

Foram encontrados em largo espectro de organismos procariotos e eucariotos e, nestes últimos, tanto no DNA nuclear como no de organelas (Tautz \& Renz, 1984; Powell et al., 1995; Moxon \& Wills, 1999; Lagercrantz et al. 1993). Localizam-se tanto em regiões não codificadoras como em exons e introns (Wang et al., 1994).

A abundância, o tipo de seqüência repetida e a composição de bases dos microssatélites mais freqüentemente encontrados variam entre as espécies (Tautz et al. 1986).

Lagercrantz et al. (1993) isolaram microssatélites de quatro espécies de Brassica e fizeram uma busca em banco de seqüências de DNA, localizando microssatélites de mais 15 espécies de plantas, inclusive gimnospermas. Concluiram que microssatélites são cinco vezes menos freqüentes em plantas que em mamíferos. As seqüências repetidas mais freqüentemente encontradas nos microssatélites de plantas foram: AA/TT, AT/TA e CT/GA, responsáveis por $75 \%$ dos microssatélites com mais de 5 repetições, enquanto o dinucleotídeo mais comum em microssatélites de mamíferos é GT/CA.

Wang et al. (1994) pesquisaram dois bancos de dados de seqüências de DNA nuclear e de organelas, de 54 e 28 plantas, respectivamente. Encontraram 134 microssaté- 
lites compostos por mono, di, tri e tetranucleotideos, sendo apenas 4 em organelas. Quanto ao tipo de seqüência repetida, 62 eram dinucleotideos (sendo 49 AT/TA), 21 mononucleotideos, 20 trinucleotideos e 18 tetranucleotideos. Todos os microssatélites formados por mono, di e tetra nucleotideos estavam em regiões não codificadoras enquanto que $57 \%$ dos microssatélites formados por trinucleotideos, que continham $\mathrm{G} / \mathrm{C}$, estavam em regiões codificadoras.

O número de repetições da seqüência simples varia de acordo com o tipo de seqüência e a espécie em que é encontrada. Kruglyak et al. (1998), analisando seqüências do genoma humano, de camundongo, da mosca da fruta e de levedura, encontraram seqüencias compostas por dinucleotideos com até 34 cópias, compostas por trinucleotideos com até 26 cópias e compostas por tetranucleotídeos com até 18 cópias. $O$ genoma de camundongo, nos três casos, foi o que apresentou microssatélites mais longos, seguido do genoma humano, levedura e mosca da fruta.

Morgante \& Olivieri (1993) encontraram uma freqüencia de um microssatélite a cada $50 \mathrm{~kb}$ analisados, em banco de seqüencias de DNA de plantas. Predominaram os microssatélites formados pela repetição do dinucleotideo AT/TA, seguidos por microssatélites com a repetição GA/CT.

Echt \& May-Marquardt (1997) encontraram em microssatélites de Pinus strobus, predominância do dinucleotídeo AC/TG sobre GA/CT e o inverso em Pinus taeda. Excetuando os microssatélites formados por AT/TA, estes dois tipos foram os mais freqüentes: 2 a 4,5 locos a cada $\mathrm{Mb}$.

Quanto à distribuição física dos microssatélites nos cromossomos de plantas, um estudo detalhado em Beta vulgaris L. foi feito por Schmidt \& Heslop-Harrison (1996). Usaram hibridação in situ e hibridação em DNA clivado com diversas enzimas de restrição. Foram escolhidas sondas complementares a sete tipos de microssatélites (três tetrâmeros, três dímeros e um trímero). Cada microssatélite apresentou um padrão específico de distribuição no genoma. Foi observada exclusão de alguns microssatélites de regiões de DNA ribossômico, de alguns centrômeros e algumas regiões intercalares.

Röder et al. (1998) usaram cruzamentos de 25 estoques com deleções de cromossomos homeólogos $2 \mathrm{~A}, 2 \mathrm{~B}$ e $2 \mathrm{D}$ de Triticum aestivum $\mathrm{L}$ para o mapeamento físico de 31 
microssatélites com os dímeros GA ou GT. De modo geral, os resultados sugeriram que os microssatélites não estavam localizados em lugares específicos dos cromossomos, sendo encontrados igualmente em regiões centroméricas, teloméricas e intersticiais. No caso do cromossomo $2 \mathrm{~B}$, que é altamente heterocromático, os microssatélites localizaram-se preferencialmente nas regiões eucromáticas.

A alta variabilidade dos locos de microssatélites está relacionada à frequeência com que ocorrem deleções ou adições da unidade repetitiva, durante as replicações do DNA. Um modelo tem sido proposto para explicar a alta incidência de mutações deste tipo nos locos de microssatélites. Trata-se do chamado deslizamento (do inglês "slippage") da DNA polimerase no processo de duplicação do DNA. Este fenômeno foi observado in vitro e supõem-se que ocorra igualmente in vivo, sendo a principal causa do aparecimento de variantes de comprimento nos locos de microssatélites (Schlötterer \& Tautz, 1992; Hite et al., 1996; Wierdl et al., 1997).

Outra possibilidade seria a ocorrência de recombinação desigual (do inglês "unequal crossover") na meiose, por pareamento desalinhado das cromátides dos cromossomos homólogos (Tautz et al., 1986; Smith, 1976). No entanto, a ocorrência predominante de alelos, de locos de microssatélites, cujo comprimento difere exatamente em múltiplos da unidade repetitiva, sugere que o processo responsável pela maioria das alterações de comprimento dos microssatélites seja o deslizamento da polimerase.

A taxa de ocorrência destas alterações em microssatélites é variável segundo o tipo de seqüência repetitiva, seu comprimento e sua posição no genoma.

Foram descritos alguns locos hipervariáveis de microssatélites em várias espécies. Moxon \& Wills (1999), descrevendo o trabalho de Thomas F. Meyer e colaboradores, relatou que genes para proteina da membrana externa de Neisseria gonorrhoeae, contêm um microssatélite formado pela repetição do pentâmero CTCTT que sofre alterações de tamanho a cada 100 a 1000 células filhas. Uma taxa de $0,1 \%$ a $1 \%$.

Maroof et al. (1994) encontraram 22 e 33 alelos em dois microssatélites de Hordeum vulgare ssp. spontaneum, examinando 103 acessos deste parente selvagem da cevada, para o qual predomina a autofecundação. 
Fischer et al. (1998), avaliando a segregação de alelos de um microssatélite de Pinus radiata, encontraram alelos novos (ou seja, que estavam ausentes nos dois pais), em $6 \%$ da progênie mapeada e dos megagametófitos dos dois indivíduos parentais utilizados. Interpretaram os dados como resultado de alta incidência de mutações neste loco.

\section{Detecção de polimorfismos em microssatélites}

Para detectar polimorfismos em microssatélites podem ser usadas duas metodologias: hibridação de sondas que contenham seqüências repetitivas (Varshney et al., 1998) ou amplificação, por PCR, de locos contendo microssatélites.

A amplificação de locos de microssatélites normalmente é feita usando-se iniciadores complementares às seqüencias flanqueadoras (a montante e a jusante) do microssatélite (Figura 4). Em geral são usados iniciadores com cerca de 20 nucleotídeos que gerem produtos de amplificaçâo com 100 e 400 pb, incluindo o microssatélite alvo.

Para definir a seqüência de nucleotideos dos iniciadores que serão usados para amplificação de cada loco, é necessário conhecer as seqüências das regiões flanqueadoras e desenhar os oligonucleotídeos mais adequados para a amplificação da região. Isto pode ser conseguido pesquisando bancos de seqüencias de DNA ou seqüenciando clones positivos para presença de microssatélites, de bancos de DNA da espécie em estudo (Lagercrantz et al., 1993).

A clonagem e seqüenciamento dos clones são atividades dispendiosas, tanto em tem-po e trabalho como em custo. Mais recentemente, para eliminar a necessidade de iniciadores específicos para cada loco, foi testado o uso de iniciadores aleatórios, como os usados para RAPD, junto com iniciadores que contivessem uma seqüência repetitiva, complementar aos microssatélites. Denominaram estes marcadores de microssatélites ancorados (do inglês "anchored microsatellite markers", Lanham \& Brennan, 1998) ou RAMPs (do inglês "random amplified microsatellite polymorphisms" = polimorfismos de microssatélite amplificados aleatoriamente, Dávila et al., 1998).

A separação dos fragmentos amplificados que contêm microssatélites normalmente é feita em géis de poliacrilamida, por permitirem resolução de fragmentos que diferem em tamanho por apenas um ou dois nucleotídeos. A visualização pode ser feita 
Microssatélite

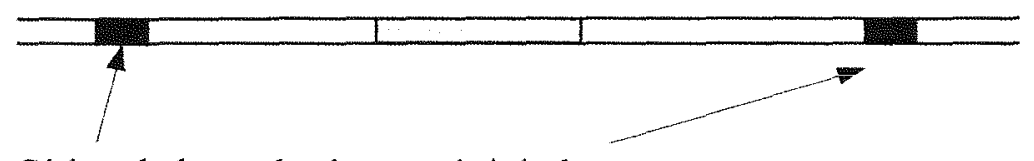

Sítios de homologia com iniciadores

Região o microssatélite

$3^{1} \quad$ Iniciador de montante

$5^{\prime}$

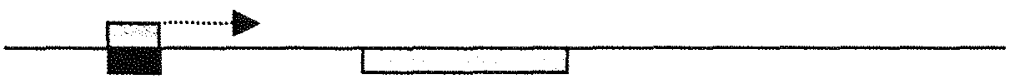

Cópia da Região que Contém

o Microssatélite

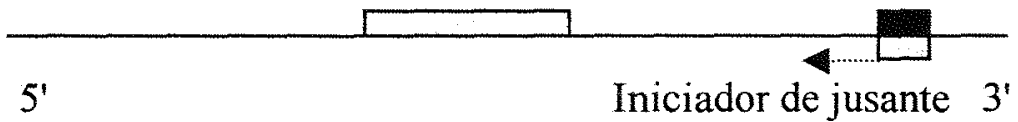

Fragmentos Amplificados

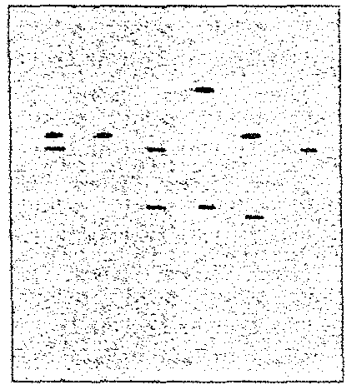

Separação dos Fragmentos Amplificados

(Eletroforese)

Figura 4 - Esquema explicativo da amplificação de microssatélites 
por coloração com nitrato de prata, autoradiografia ou fluorescência.

\section{Problemas na análise de polimorfismos de microssatélites}

A manifestação, in vitro, da tendência dos microssatélites em sofrerem adições e deleções de sua unidade repetitiva, pode ter como conseqüência a formação de bandas espúrias nos géis, dificultando a interpretação dos resultados. Alguns tipos de seqüência repetitiva dos microssatélites são especialmente susceptiveis a este efeito. As bandas extras diferem da banda principal por múltiplos da unidade repetitiva do microssatélite.

Hite et al. (1996) demonstraram que os fragmentos de tamanho diferente eram predominantemente mais curtos do que o molde. $\mathrm{O}$ único dos fatores testados, que reduziu a produção destas bandas, foi a amplificação a temperaturas baixas ( 37 graus centígrados em lugar dos 72 graus regularmente utilizados). Provavelmente porque, em baixas temperaturas, a ocorrência de parcial dissociação das fitas de DNA que estão sendo amplificadas se reduz, minimizando o efeito de escorregamento da enzima no processo de sintese.

A determinação do tamanho exato dos fragmentos amplificados também pode ser prejudicada pela adição, pela polimerase, de um nucleotideo excedente na extremidade $3 "$ dos fragmentos produzidos. Nem todos os tipos de enzimas, porém, produzem este efeito e como todas as bandas ficam aumentadas de um nucleotideo, a avaliação relativa dos padrões num gel não é seriamente prejudicada (Hite et al., 1996).

Mesmo usando procedimentos refinados para a separação dos fragmentos amplificados, a grande semelhança de tamanho entre alelos pode constituir um problema para a correta análise dos genótipos, especialmente na comparação de amostras em géis diferentes. Ghosh et al. (1997) sistematizaram todos os cuidados que podem ser tomados no sentido de minimizar o erro no uso de microssatélites para estudos genéticos.

Os fragmentos produzidos por PCR na amplificação dos microssatélites incluem, além do próprio microssatélite, seqüências flanqueadoras situadas entre o microssatélite e as regiões de homologia com os iniciadores. Alterações nestas regiões também podem colaborar com a variação no tamanho dos fragmentos amplificados (Akagi et al., 1998; Kostia et al., 1995). 
Alterações na região de homologia dos iniciadores podem impedir a amplificação. Estes alelos não amplificados têm sido denominados alelos nulos (Fisher et al., 1998). Sua ocorrência é relativamente comum (Pemberton et al., 1995), sobretudo quando se usam iniciadores que foram desenhados para uma determinada espécie para amplificar microssatélites de espécies correlatas. A existência de alelos nulos deve ser levada em consideração nas análises baseadas em dados de microssatélites, pois pode levar a erro, uma vez que indivíduos heterozigotos para um alelo nulo serão avaliados como homozigotos para o alelo amplificado.

\subsubsection{Avaliação da diversidade genética em plantas cultivadas com marcadores moleculares}

Villand et al. (1998) avaliaram a diversidade genética de 96 acessos de tomate (Licopersicum esculentum Mill.) e seu provável ancestral selvagem, Licopersicum esculentum var. cerasiforme. Usaram 41 iniciadores para produzir polimorfismos do tipo RAPD. Selecionaram 93 bandas polimórficas para calcular a similaridade genética (concordância simples), índice de diversidade de Nei e a distribuição da variabilidade entre três subgrupos: 21 acessos oriundos do centro primário de diversidade, 58 acessos oriundos de regiões contíguas ao centro primário e 38 acessos de diferentes centros secundários de diversidade. A representação gráfica, por "multi-dimensional scaling plot", mostrou pouca distinção entre os subgrupos, com maior dispersão das plantas do centro primário de diversidade. Encontraram poucas marcas especificas de algum subgrupo mas considerável variação nas freqüências das marcas de RAPD entre os subgrupos, o que interpretaram com sendo consistente com a divergência de subpopulações depois de levadas de seu local de origem para novos centros. A divergência entre os acessos da cultivar e de sua variante selvagem não foi significativa, sendo comparável às variações encontradas entre os três subgrupos da variante cultivada.

Ferguson et al. (1998) avaliaram a diversidade genética de 160 variedades locais de lentilha (Lens culinaris) de 16 países, 10 variedades de cada um. Usaram sete locos isoenzimáticos (com 16 alelos) e 22 bandas polimórficas de RAPD (amplificadas com quatro iniciadores da OPERON). Os resultados sugerem a formação de 2 grupos: o pri- 
meiro incluindo os três países do sul da Ásia mais o Afeganistão e o segundo incluindo os demais países, subdivididos em 4 subgrupos: da Etiópia (e Yemen), do Levante, da Europa e do Irã (e Egito). A distância genética média (Nei) entre paises variou de $\mathrm{D}=$ 0,003 a $\mathrm{D}=0,741$ para $\mathrm{RAPD}$ e de $\mathrm{D}=0,005$ a $\mathrm{D}=0,812$ para isoenzimas. A correlação entre as matrizes de similaridade geradas pelos dois tipos de marcador foi $r=0,94581$. Os índices de diversidade de Shannon variaram de $d=1,15$ a $d=8,48$ para $R A P D$ e de $\mathrm{d}=0,50 \mathrm{a} d=2,98$ para isoenzimas. A correlação (tau de Kendall) entre as medidas de diversidade feitas pelos dois métodos foi de $\tau=0,333(\mathrm{P}=0,072)$.

Provan et al. (1996) utilizaram polimorfismos em 16 locos de microssatélites para avaliar variabilidade e distância genética entre 18 cultivares tetraplóides. Detectaram a presença de 2 a 19 alelos (média de 6,813) e heterozigozidade entre $\mathrm{h}=0,408 \mathrm{e}$ $\mathrm{h}=0,921$ (média de 0,794). Os índices de similaridade calculados pelo coeficiente de concordância simples, variaram entre $S=0,44$ e $S=0,81$ e devem ser tomadas apenas como referência pois, como os individuos são auto-tetraplóides e predomina a fecundação cruzada, não foi possível determinar com exatidão os genótipos.

Olufowote et al. (1997) avaliaram 259 indivíduos de 71 cultivares de arroz para determinar variabilidade dentro das cultivares e entre acessos da mesma cultivar. Usaram 12 locos de microssatélites e 12 locos de RFLP, mapeados em diferentes cromossomos, além de marcadores fenotípicos, para definir a pureza das sementes de algumas cultivares. Os resultados mostraram que tanto microssatélites como RFLPs podem detectar variações genéticas em cultivares purificadas por avaliação fenotípica. Também detectaram variação entre acessos com o mesmo nome. Os valores de PIC (do inglês: "polymorphism information content" = conteúdo de informação sobre polimorfismo) para os 12 locos de RFLP variaram de PIC $=0,000$ a $\mathrm{PIC}=0,646$ (média de PIC $=$ 0,265 ) e para os microssatélites de PIC $=0,311$ a $\mathrm{PIC}=0,864$ (média de $\mathrm{PIC}=0,685$ ). Os microssatélites foram mais eficientes em detectar variações intravarietais.

Yang et al. (1994), usando 10 microssatélites, avaliaram variabilidade genética de 238 acessos de arroz, sendo 140 raças locais (135 representando a maior parte das regiões de plantio de arroz na China) e 98 variedades melhoradas. Destes, 129 acessos foram previamente identificados como indica e 103 como japonica. Estes resultados 
mostraram mais variabilidade por loco que estudos anteriores sobre arroz com isoenzimas, DNA mitocondrial ou RFLP. Foram detectados de 3 a 25 alelos por loco, com média de 9,3. Foi encontrada maior variabilidade em indica que em japonica e mais variabilidade nas variedades locais que nas melhoradas. A proporção da variabilidade devida à divisão indica $\times$ japonica foi $10 \%$. A menor variabilidade, encontrada entre as variedades melhoradas, se deveu mais à ausência de alelos que aos índices médios de diversidade.

Powell et al. (1996) avaliaram 700 genótipos de soja (Glycine soja e Glycine max) com 115 marcas mapeadas de RFLP (pelo menos quatro em cada um dos 20 grupos de ligação). Em função destes resultados, selecionaram 12 linhagens (10 de G. max e 2 de G. soja) que representavam $92 \%$ do total da variabilidade detectada e reavaliaram este grupo em função de 11 microssatélites. Os resultados foram comparados com 25 acessos de Glycine soja oriundos de 6 diferentes regiões e com 12 acessos de Glycine max. Foram encontrados no total 129 alelos, dos quais 91 (a maioria de Glycine soja) não estavam presentes no grupo selecionado com base em RFLP. O grupo selecionado representou apenas $40 \%$ da variabilidade nos 11 locos de microssatélites. Os agrupamentos feitos a partir de indices de similaridade permitiram uma boa separação de $G$. max e G. soja.

Papa et al. (1998), utilizando cinco caracteres morfológicos, seis locos isoenzimáticos ( 2 polimórficos) e 77 bandas de RAPD ( $17 \%$ polimórficas), estimaram a variabilidade genética de doze populações (vinte linhagens de cada) de cevada (Hordeum vulgare L.) oriundas das regiôes norte e sul da ilha da Sardenha (Itália). Avaliados em conjunto, estes marcadores permitiram a discriminação de $90,5 \%$ dos 231 indivíduos. Para os três tipos de marcadores, a porção da variabilidade devida à divisão em populações foi estimada em $\mathrm{G}_{\mathrm{ST}}=0,164 ; \mathrm{G}_{\mathrm{ST}}=0,161$ e $\mathrm{G}_{\mathrm{ST}}=0,107$, respectivamente. Foi encontrada uma baixa correlação $\left(r^{2}=0,35 ; P=0,043\right)$ entre os índices de diversidade $(H$; Nei) estimados a partir de RAPD e isoenzimas. Mas nenhuma correlação entre os estimados por morfologia e por marcadores moleculares. Apesar da variabilidade detectada, concluíram que todas as populações pertencem a uma mesma raça local chamada de S"orgiu sardu, pelos agricultores. 
Struss \& Plieske (1998) avaliaram diversidade genética de 163 acessos de Hordeum do banco de germoplasma IPK Gatersleben, Alemanha, sendo 46 linhagens das espécies selvagens $H$. vulgare ssp. spontaneum e H. vulgare ssp. agriocrithon, e 117 raças locais, cultivares tradicionais e cultivares modernos de cevada. Usaram 15 microssatélites. Encontraram de 5 a 15 alelos por loco (média 8,6), com um índice de diversidade (Weir) variando de $\mathrm{ID}=0,64$ a $\mathrm{ID}=0,88$. $\mathrm{O}$ valor médio para as variantes selvagens e raças locais foi de $\mathrm{ID}=0,74$ e para as cultivares de $\mathrm{ID}=0,72$. Os índices (Dice) de similaridade médios entre plantas foi de $S=0,25$ para as selvagens, $S=0,27$ para as raças locais e de $S=0,30$ para as cultivares.

Chowdari et al. (1998) analisaram a variabilidade genética de milheto [Pennisetum glaucum (L.) R. Br] usando hibridação com uma sonda para microssatélites (GATA) e RAPD. Foram feitos vários ensaios envolvendo 12 a 21 cultivares e 18 a 36 raças locais, de várias regiões da Índia. Encontraram índices (Dice) de similaridade entre $\mathrm{S}=0,33$ e $\mathrm{S}=0,65$ em comparações envolvendo cultivares e raças locais com base no microssatélite. Para as cultivares apenas, os valores estiveram entre $\mathrm{S}=0,64$ e $\mathrm{S}=0,90$. Os dados de RAPD levaram a valores de similaridade entre $\mathrm{S}=0,54$ e $\mathrm{S}=0,86$ para cultivares e $S=0,64$ e $S=0,85$ para as raças locais. Não encontraram muita correlação entre dendrogramas gerados a partir dos dois tipos de marcador. Os agrupamentos baseados nos marcadores de DNA não refletiram a origem geográfica das raças locais.

Cattan-Toupance et al. (1998) estudaram a estrutura genética de populações naturais de feijão (Phaseolus vulgaris) no centro de origem sul andino. Coletaram 128 plantas de 21 populações de três províncias no noroeste da Argentina e avaliaram a variabilidade genética por meio de tipos de faseolina, RAPD e fatores de resistência a antracnose. De modo geral a variabilidade genética foi reduzida. Encontraram pouco polimorfismo quanto a tipos de faseolina e apenas cinco, entre 54 iniciadores para RAPD, apresentaram polimorfismo ( 7 bandas polimórficas). A partição hierárquica da diversidade indicou que a porcentagem da diversidade de indivíduos dentro de populações dentro de províncias foi alta. Os valores encontrados, segundo o tipo de marcador empregado, fo$\operatorname{ram} 43,6 \%$ (faseolina), 67,5\% (RAPD) e 56,9\% (resistência a antracnose). Não houve correlação entre as matrizes de distância calculadas para os três tipos de marcador. Hou- 
ve um pequena correlação entre distância geográfica e distância genética calculada a partir de RAPD $(r=0,2, P<0,005)$. Os autores consideraram que os resultados indicam menor variabilidade nesta região que entre populações de feijão do México e que a resistência à antracnose, uma das principais doenças do feijoeiro, pode ser um fator importante influenciando a distribuição da variabilidade dentro e entre populações.

Entre outras plantas cultivadas, que tiveram sua variabilidade genética estudada com uso de marcadores de DNA, estão: Vicia faba L. (Link et al., 1995), Triticum urartu e Triticum monococcum (Vierlig \& Nguyen, 1992), Brassica juncea L. (Rabbani et al., 1998), Carica papaya L. (Stiles et al., 1993), Lens culinaris Medik. (Alvarez et al., 1997), Pistacia vera (Hormaza et al., 1994), Secale cereale (Loarce et al., 1996), Persea americana Mill. (Mhameed et al., 1997) e Triticum aestivum (Barrett \& Kidwell, 1998). 


\section{MATERIAL E MÉTODOS}

\subsection{Material}

Foram avaliadas 45 etnovariedades de mandioca, provenientes da Amazônia, 9 do Litoral sul do Estado de São Paulo e uma variedade comercial, a Mantiqueira. As plantas da região amazônica provêm de três sub-regiões: Rio Negro, Rio Branco e Rio Solimões. Na Tabela 2, as variedades estão agrupadas segundo o local de coleta: roça, comunidade, sub-região, município e Estado.

As etnovariedades foram coletadas em roças de agricultores tradicionais, indigenas ou caiçaras. De cada variedade identificada pelo agricultor foram cortadas manivas de uma ou duas plantas. Apenas uma planta de cada variedade foi usada na determinação das marcas de DNA.

Esse tipo de amostragem da população de mandioca nas roças gera dois tipos de distorção: primeiro, não se leva em conta a proporção em que as variedades estão representadas na roça. Diversos levantamentos feitos em roças de agricultores tradicionais mostram que freqüentemente algumas variedades são plantadas em muito maior quantidade que outras (Peroni, 1998; Boster, 1984; Salick, 1997). No cálculo de heterozigosidade $(\mathrm{H})$, por exemplo, haverá superestimação.

Outro tipo de distorção se deve a que, apesar das variedades de mandioca serem plantadas por estacas, formando, portanto, populações clonais, uma variedade freqüentemente é composta de mais de um genótipo (Peroni, 1998). Como em nossa amostragem, usamos apenas uma planta de cada variedade, as estimativas de diversidade ficam subestimadas.

Por causa destas distorções, as plantas estudadas não foram consideradas amostras populacionais representativas dos locais de origem mas apenas grupos de plantas de mesmo local de origem.

A coleta das plantas na Amazônia foi realizada em 1992/93 por Paulo Sodero Martins, em viagem preferencialmente dirigida para a coleta de arroz selvagem (Martins, 1994b). A amostragem de populações de mandioca não foi extensiva nem pretende ser uma fiel representação do germoplasma das regiões amostradas. 
Tabela 2 - Variedades de mandioca

\begin{tabular}{|c|c|c|c|c|c|}
\hline Identificacão & Nome & Estado & Município & Localidade & Uso $^{*}$ \\
\hline \multicolumn{6}{|l|}{ Rio Negro } \\
\hline DG038 & Maniva lnajá & Amazonas & Barcelos & Comunidade Piloto & $F$ \\
\hline DG039 & Macaxeira Branca & Amazonas & Barcelos & Comunidade Piloto & $\mathrm{M}$ \\
\hline DGO40 & Branquinha & Amazonas & Barcelos & Comunidade Marará - Índios Tukâno & F \\
\hline DG041 & sem nome & Amazonas & Barcelos & Comunidade Marará - Indios Tukâno & $\mathrm{F}$ \\
\hline $\mathrm{DGO42}$ & Mandioca São João & Amazonas & Barcelos & Cormunidade Marará - Indios Tukâno & $E$ \\
\hline DG043 & Pretinha & Amazonas & Barcelos & Comunidade Marará - Índios Tukâno & $\mathrm{F}$ \\
\hline DG044 & Mandioca do Antonio & Amazonas & Barcelos & Comunidade Marará - Indios Tukâno & $F$ \\
\hline $\mathrm{DG} 045$ & Macaseira & Amazonas & Barcelos & Comunidade Marará - Indios Tukâno & $\mathrm{M}$ \\
\hline DGO46 & Orelha de Burro & Amazonas & Barcelos/Anati & Comunidade D. Pedro II & $F$ \\
\hline DGO47 & Mamaroca & Amazonas & Barcelos/Anati & Comunidade D. Pedro II & $F$ \\
\hline DG048 & Tartaruga & Amazonas & Barcelos/Anati & Comunidade D. Pedro II & $F$ \\
\hline DG049 & Amarela II & Amazonas & Carvoeiro & & $F$ \\
\hline DGO50 & & & & & $\mathrm{F}$ \\
\hline DG051 & Pretinha & Amazonas & Carvoeiro & & $F$ \\
\hline DG052 & Seis Meses & Amazonas & Carvoeiro & & $\mathrm{F}$ \\
\hline DG054 & Antinha & Amazonas & Carvoeiro & & $\mathrm{F}$ \\
\hline $\mathrm{DG} 055$ & Anará & Amazonas & Carvoeiro & & $\mathrm{F}$ \\
\hline DG056 & Arapari & Amazonas & Carvoeiro & & $F$ \\
\hline DG058 & Amarela I & Amazonas & Carvoeiro & & $F$ \\
\hline DG059 & Samuauma & Amazonas & Carvoeiro & & $F$ \\
\hline DG060 & sem identificação I & Amazonas & Carvoeiro & & $\mathrm{F}$ \\
\hline DG061 & Macaxeira & Amazonas & Carvoeiro & & $\mathrm{F}$ \\
\hline DG062 & sem identificação II & Amazonas & Carvoeiro & & $F$ \\
\hline \multicolumn{6}{|l|}{ Rio Branco } \\
\hline DG065 & Anará & Roraima & Marará & & $\mathrm{F}$ \\
\hline DG067 & Roxinha & Roraima & Marará & & $\mathrm{F}$ \\
\hline DG068 & Macaxeira Pâo & Roraima & Castanho & & $\mathrm{F}$ \\
\hline DG069 & Camarâo & Roraima & Castanho & & $F$ \\
\hline DG070 & Tala Encarnada & Roraima & Panarica & & $\mathrm{F}$ \\
\hline DG073 & Socó & Roraima & Panarica & & $F$ \\
\hline \multicolumn{6}{|l|}{ Rio Solimões } \\
\hline DG111 & Geoató & Amazonas & Uairini & Comunidade São Sebastiâo & $F$ \\
\hline DG112 & Pretinha & Amazonas & Uairini & Comunidade Sâo Sebastião & $\mathrm{F}$ \\
\hline DG113 & Antinha & Amazonas & Uairini & Comunidade São Sebastião & $F$ \\
\hline DG114 & de semente & Amazonas & Uairini & Comunidade São Sebastião & $F$ \\
\hline DG115 & Maguari & Amazonas & Guarabira & Comunidade São Joâo - Lago Mamiá & F \\
\hline DG116 & Ourinho & Amazonas & Guarabira & Comunidade São João - Lago Mamiá & $F$ \\
\hline DG118 & Macaxeira & Amazonas & Guarabira & Comunidade São João - Lago Mamiá & $\mathrm{F}$ \\
\hline DG138 & Antinha & Amazonas & Guarabira & Lago Mamiá & $F$ \\
\hline DG117 & Caneová & Amazonas & Guarabira & Lago Mamiá & $\mathrm{F}$ \\
\hline DG119 & Macaxeira & Amazonas & Guarabira & Lago Mamiá & $\mathrm{F}$ \\
\hline DG120 & Antinha & Amazonas & Guarabira & Lago Mamiá & $F$ \\
\hline DG121 & Turuna & Amazonas & Guarabira & Lago Mamiá & $\mathrm{F}$ \\
\hline
\end{tabular}


Tabela - Variedades de mandioca

(Continuação)

\begin{tabular}{|c|c|c|c|c|c|}
\hline Identificacão & Nome & Estado & Municipio & Localidade & Uso* \\
\hline $\mathrm{DG} 122$ & Marreca (semente) & Amazonas & Guarabira & Lago Mamiá & $\mathrm{F}$ \\
\hline DG123 & Antinha $\times$ Maneca & Amazonas & Guarabira & Lago Mamiá & $F$ \\
\hline $\mathrm{DG} 124$ & Macaxeira & Amazonas & Guarabira & Lago Mamiá & $F$ \\
\hline DG125 & sem identificação & Amazonas & & Lago Amanâ & $F$ \\
\hline \multicolumn{6}{|l|}{ Litoral SP } \\
\hline DG126 & Aipim Roxo & São Paulo & Cananéia & Dona Saturnina & $\mathrm{F}$ \\
\hline DO127 & Aipim Roxo (semente) & São Paulo & Cananéia & Dona Saturnina & $F$ \\
\hline$\overline{\text { DG128 }}$ & Manteiga (aipim) & São Paulo & Cananéia & Dona Saturnina & $M$ \\
\hline DG129 & Aipim Mata Fome & São Paulo & Cananéia & Sr. Natalicio & $\mathrm{M}$ \\
\hline DG130 & Vassourinha & Sâo Paulo & Cananéia & Sr. Silvio Ramos & $\bar{M}$ \\
\hline DG131 & Manteiguinha & Sâo Paulo & Cananéia & Sr. Silvio Ramos & $\mathrm{M}$ \\
\hline DG132 & Aipim Roxo & São Paulo & Cananeia & Dona Tuca & $\mathrm{M}$ \\
\hline & & & & & \\
\hline DG133 & Manteiga & São Paulo & Ilha Comprida & Comunidade Pedrinhas & $\bar{M}$ \\
\hline DGI34 & Aipim Roxo & São Paulo & llha Comprida & Comunidade Pedrinhas & $\mathrm{M}$ \\
\hline \multicolumn{6}{|l|}{ IAC } \\
\hline DG137 & Mantiqueira & São Paulo & Campinas & Instituto Agronômico de Campinas & $\mathrm{M}$ \\
\hline
\end{tabular}

(*) $\mathrm{F}=$ Farinha, $\mathrm{M}=$ Mesa 
Foi a primeira coleta de variedades de mandioca da Amazônia, para a coleção de germoplasma de mandioca do Departamento de Genética de ESALQ, e havia interesse em avaliar a diversidade genética do material. O primeiro trabalho neste sentido, foi feito por Roberto Cury (Cury, 1998), usando descritores morfológicos, caracteres agronômicos e bioquimicos. Das variedade amazônicas, 46 foram escolhidas para este primeiro trabalho.

Para servir de comparação com as plantas da Amazônia, foram escolhidas 9 variedades tradicionais do Litoral sul do Estado de São Paulo. Estas plantas foram selecionadas em função da disponibilidade de ramas para o plantio dos experimentos de avaliação morfológica, agronômica e bioquímica. Não são consideradas como uma ampla representação do germoplasma da região de origem. Por coincidência, todas elas são aipins, ainda que na região de origem existam muitas variedades de mandioca brava.

No presente estudo, foram avaliadas 55 das variedades usadas por Cury (1998).

Depois de coletadas, as plantas vêm sendo mantidas na coleção de germoplasma de mandioca do Departamento de Genética da ESALQ, no campo, replantadas a cada ano.

\section{2. Métodos}

\subsubsection{Metodologia para extração de DNA}

(Dellaporta et al., 1983 - com modificações)

Colocar em banho-maria a $65^{\circ} \mathrm{C}, 1 \mathrm{ml}$ de tampão $\mathrm{CTAB}$ com $1 \%$ de $\beta$ mercaptoetanol, em tubo de $2 \mathrm{ml}$.

Congelar 100 a $250 \mathrm{mg}$ de material vegetal em nitrogênio líquido. (Neste estado o material pode ser conservado a $-80^{\circ} \mathrm{C}$ ). Triturar no gral, resfriado previamente, até obter um pó fino.

Colocar o triturado dentro do tubo com tampão $\mathrm{CTAB}$, no banho-maria e misturar bem com espátula. Deixar agir por 30 minutos, agitando ocasionalmente.

Acrescentar $700 \mu \mathrm{l}$ de clorofórmio-octanol (24:1) e homogeneizar bem com espátula. Centrifugar por 15 minutos. 
Recuperar a fase aquosa $(500 \mu \mathrm{l}$ a $600 \mathrm{~m} \mu \mathrm{l})$ e adicionar $1 \mathrm{ml}$ de isopropanol. Agitar.

Deixar 20 a 30 minutos se necessário. A precipitação, em geral, é imediata. Centrifugar por 15 minutos. Descartar o sobrenadante e secar o tubo com cotonete.

Lavar o precipitado com $1 \mathrm{ml}$ de soluçâo de lavagem. Deixar por 20 minutos no mínimo.

Centrifugar por 10 minutos. Despejar o sobrenadante cuidadosamente. Secar o tubo com cotonete. Ressuspender em $100 \mu \mathrm{l}$ de TE.

Precipitar com $50 \mu \mathrm{l}$ de acetato de amônio $7,5 \mathrm{M}$ e $375 \mu \mathrm{l}$ de etanol absoluto gelado. Deixar por 30 minutos em geladeira. Centrifugar 15 minutos. Descartar o sobrenadante. Ressuspender em volume adequado de TE.

Para extração de DNA foram coletadas folhas maduras de mandioca, em estado sanitário de razoável a bom, de plantas mantidas em canteiro ou estufa, próximos aos laboratórios.

\section{Tampão CTAB}

TrisBase*, pH 8,0

$100 \mathrm{mM}$

$\mathrm{NaCl}$

$1,4 \mathrm{M}$

CTAB**

EDTA. $4 \mathrm{Na}^{* * *}$

$2,5 \% \mathrm{p} / \mathrm{v}$

PVP**** (P.M. 40 000)

$20 \mathrm{mM}$

$\mathrm{H}_{2} \mathrm{O}$ (destilada)

$1 \% \mathrm{p} / \mathrm{v}$

q.s.v.

Autoclavar a 1 atmosfera, $120^{\circ} \mathrm{C}$, por 15 minutos.

* TrisBase $=$

** $\mathrm{CTAB}=$ Brometo de Cetiltrimetilamônio

$* * * \mathrm{EDTA}=$

**** PVP $=$ Polivinilpirrolidona 


\section{Solução de lavagem}

Etanol

$76 \% \mathrm{v} / \mathrm{v}$

Acetato de Amônio

$10 \mathrm{mM}$

$\mathrm{H}_{2} \mathrm{O}$ (destilada)

q.s.v.

\section{TE (pH 8,0)}

$\begin{array}{lr}\text { TrisBase }(\mathrm{pH} 8,0) & 0,010 \mathrm{M} \\ \text { EDTA } & 0,001 \mathrm{M} \\ \mathrm{H}_{2} \mathrm{O} \text { (destilada) } & \text { q.s.v. }\end{array}$

Autoclavar a 1 atmosfera, $120^{\circ} \mathrm{C}$, por 15 minutos.

\subsubsection{Metodologia para obtenção de bandas de RAPD}

(Williams et al. 1990, Welsh \& McClelland 1990 - com modificações)

DNA de cada uma das variedades, foi extraido conforme metodologia descrita acima.

Foi feita uma quantificação do DNA em gel de agarose. Alíquotas de $5 \mu$ da suspensão final de DNA em TE foram submetidas a eletoforese e a quantificação foi feita por comparação da intensidade da coloração das bandas com um padrão de concentração conhecida. Foi usado como padrão DNA do fago Lambda, não clivado, fornecido pela Pharmacia. Além da concentração, este teste serviu para avaliar a qualidade do DNA e a existência de degradação.

Após a quantificação, parte de cada amostra de DNA foi diluída até uma concentração aproximada de 10 a $50 \mathrm{ng} / \mu \mathrm{l}$ para uso nas reações de amplificação. O restante foi estocado a

$-20^{\circ} \mathrm{C}$.

As reações de amplificação foram feitas em vários termocicladores do Departamento de Genética e de Zootecnia de Não Ruminantes, na ESALQ, segundo a disponibilidade. Para evitar variação nos resultados, todas as reações com um mesmo iniciador foram feitas num mesmo equipamento. 
Os parâmetros de temperatura e duração de cada ciclo de amplificação estão especificados abaixo, assim como os componentes das reações de amplificação do DNA. Para as reações, foram usados tubos de polipropileno tipo "eppendorff" com capacidade para 0,5 ml. A mistura para a reação foi recoberta com óleo mineral Nujol para impedir a evaporação.

Foram testados os 40 iniciadores dos "kits" X e E, fornecidos pela empresa OPERON. Foram aproveitados 38 iniciadores na análise final dos polimorfismos de RAPD. Apenas os iniciadores OPERON E13 e OPERON E18, não produziram bons padrões de bandas.

O DNA amplificado foi submetido a eletroforese em géis de agarose a 1,5\% para separação dos fragmentos segundo seu peso molecular. A eletroforese foi feita em cubas horizontais de acrílico, a temperatura ambiente, por 3,5 horas, a 3 volts por centímetro. Como padrão de peso molecular das bandas, foi usado o marcador "ladder" de 100 pares de bases fornecido pela GIBCO.

Após a eletroforese, os géis foram corados em solução de brometo de etideo por 10 minutos, lavados em água destilada para remoção de excesso de brometo de etídeo por no mínimo 30 minutos, expostos a luz ultravioleta e fotografados com câmara convencional, lente de $50 \mathrm{~mm}$, filtro cor laranja, filme Kodak T-Max 100. As revelações dos filmes e as cópias em papel Ilford foram feitas no laboratório de fotografia do Departamento de Genética, seguindo as especificações dos fabricantes do material. A Figura 5 mostra um exemplo de fotografia de um gel, usada para identificação das bandas.

\section{Parâmetros de temperatura e duração dos ciclos para amplificação de DNA em termociclador - RAPD \\ $94^{\circ} \mathrm{C}-5 \mathrm{~min}$ $40^{\circ} \mathrm{C}-1,5 \mathrm{~min} \quad 72^{\circ} \mathrm{C}-2 \mathrm{~min} \quad \begin{aligned} & 1 \text { ciclo } \\ & 40 \text { ciclos }\end{aligned}$ \\ $94^{\circ} \mathrm{C}-1 \mathrm{~min}$ $69^{\circ} \mathrm{C}-10 \mathrm{~min}$ \\ 1 ciclo}




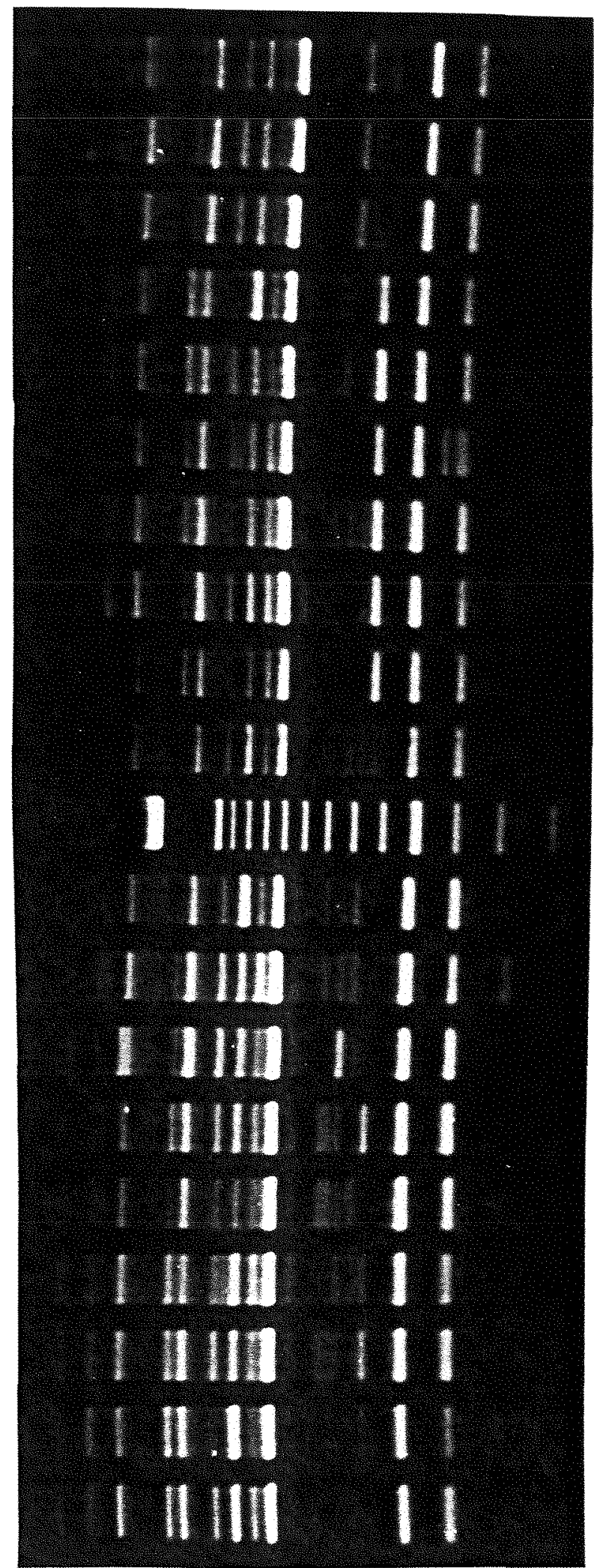

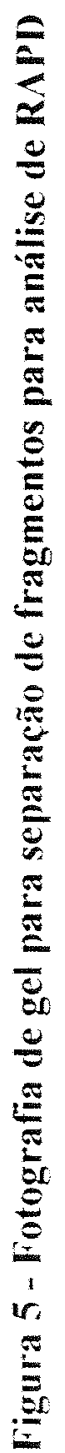


Componentes da reação de amplificação de DNA - RAPD

Taq DNA polimerase

$0,75 \mathrm{U}$

Solução tampão $10 \times$ concentrada

$10 \%$

$\mathrm{MgCl}_{2}$

$2,5 \mathrm{mM}$

dNTPs

$0,5 \mathrm{mM}$

iniciadores

$0,4 \mu \mathrm{M}$

DNA molde

$10-75 \mathrm{ng}$

$\mathrm{H}_{2} \mathrm{O}$ (destilada)

q.s.p.

Volume total $15,0 \mu \mathrm{l}$

TBE $10 x$

TrisBase

$108 \mathrm{~g}$

Ácido bórico

$55 \mathrm{~g}$

EDTA (solução 0,5 M, pH 8,0)

$40 \mathrm{ml}$

$\mathrm{H}_{2} \mathrm{O}($ destilada $)$

q.s.v.

Autoclavar a 1 atmosfera, $120^{\circ} \mathrm{C}$, por 15 minutos.

Gel de agarose $1 \%$

TBE $10 \mathrm{x}$

$10 \% \mathrm{v} / \mathrm{v}$

Agarose

$1 \% \mathrm{p} / \mathrm{v}$

$\mathrm{H}_{2} \mathrm{O}$ (destilada)

q.s.v.

Para a perfeita dissolução da agarose em TBE e água destilada é necessário aquecer (em microondas ou diretamente no fogo) até o ponto de fervura. Observar se não restaram cristais não dissolvidos. A seguir deixar resfriar até cerca de $60^{\circ} \mathrm{C}$ e despejar em molde adequado, com pente(s) para formação das canaletas onde serão aplicadas as amostras de DNA. Deixar esfriar até completo endurecimento do gel. 


\subsubsection{Metodologia para obtenção de bandas de microssatélites}

(Chavarriaga-Aguirre et al., 1998; Roa, 1996 - com modificações)

DNA de cada uma das variedades de mandioca, extraído segundo metodologia descrita acima e conservado a $-20^{\circ} \mathrm{C}$, foi quantificado em fluorimetro e diluído em TE até uma concentração aproximada de 15 e $30 \mathrm{ng} / \mu 1$.

O DNA foi amplificado em termociclador, no Laboratório de Biotecnologia do CIAT.

Os parâmetros de temperatura e duração de cada ciclo de amplificação estão especificados abaixo, assim como os componentes das reações de amplificação do DNA. Para as reações foram usados tubos de polipropileno tipo "eppendorff" com capacidade para 0,2 $\mathrm{ml}$.

Os 11 pares de iniciadores para amplificação dos 11 locos de microssatélites, desenvolvidos especialmente para mandioca, (Chavarriaga-Aguirre et al., 1998) foram produzidos pelas empresas Perkin-Elmer e Reserch Genetics e marcados com dois tipos de fluorescência.

O DNA amplificado foi submetido a eletroforese em gel desnaturante de acrilamida (19:1) a $4 \%$, para separação dos fragmentos segundo seu peso molecular. A eletroforese foi feita em equipamento $\mathrm{ABI}$ Prism 377 , a $50^{\circ} \mathrm{C}$, por 3 horas, a 3000 volts, com tampão TBE. Foi usada uma matriz de gel previamente preparada no CIAT, o filtro utilizado foi o filtro C e o módulo C 2400 . Foram usados pentes com dentes retangulares e moldes para géis verticais de $36 \mathrm{~cm}$.

Para aplicação no gel, alíquotas de $2,0 \mu \mathrm{l}$ do DNA amplificado foram misturadas com $0,5 \mu$ l do marcador de peso molecular e $2,5 \mu$ le uma solução $5: 1$ de formamida deionizada e Blue Dextran 50mg/ml em EDTA $25 \mathrm{mM} \mathrm{pH} \mathrm{8,0.} \mathrm{Imediatamente} \mathrm{antes} \mathrm{da} \mathrm{aplica-}$ ção, estas amostras foram desnaturadas por 2 minutos a $95^{\circ} \mathrm{C}$ e a seguir mantidas em recipiente com gelo.

Como padrão para cálculo de peso molecular das bandas, foi usado o marcador fluorescente TAMRA 500 fornecido pela Perkin-Elmer.

As imagens dos géis, digitalizadas pelo programa GeneScan, foram transformadas em gráficos, com picos representando as bandas. A análise dos gráficos foi feita com o 


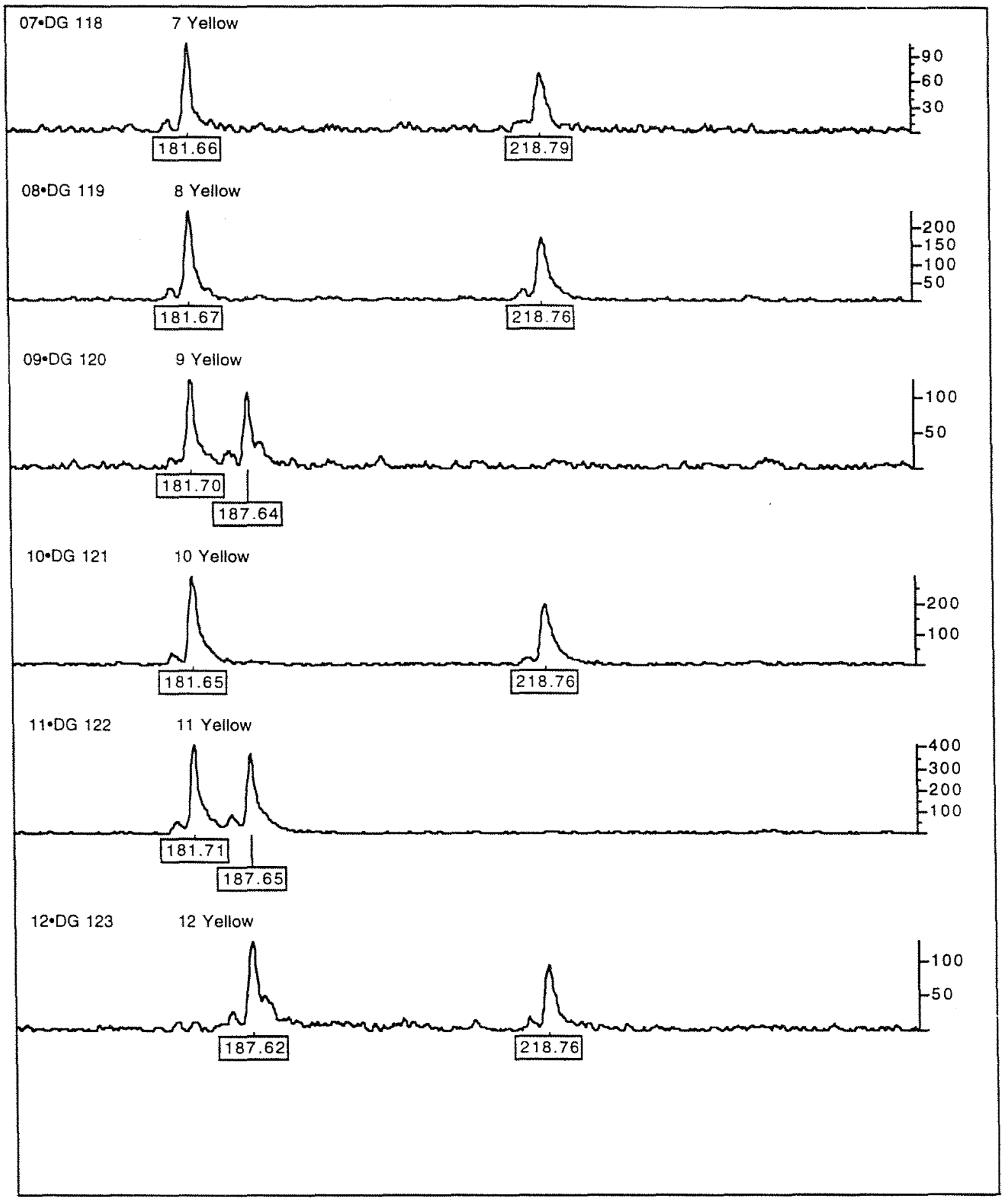

Figura 6 - Gráficos representando os alelos dos locos de microssatélites 
programa Genotyper. A Figura 6 mostra um exemplo de gráficos usados para identificação de alelos de microssatélites.

Componentes da reação de amplificação de DNA - Microssatélites

Taq DNA polimerase

$0,75 \mathrm{U}$

Solução tampão $10 \times$ concentrada

$10 \%$

$\mathrm{MgCl}_{2}$

$2,5 \mathrm{mM}$

dNTPs

$0,5 \mathrm{mM}$

iniciadores

$10 \mathrm{mM}$

DNA molde

$25-50 \mathrm{ng}$

$\mathrm{H}_{2} \mathrm{O}$

q.s.p.

Total $25,0 \mu \mathrm{l}$

Programa para amplificação de DNA em termociclador - Microssatélites

$94^{\circ} \mathrm{C}-2 \mathrm{~min}$

$94^{\circ} \mathrm{C}-1 \mathrm{seg}$

$69^{\circ} \mathrm{C}-30 \mathrm{~min}$

$56^{\circ} \mathrm{C}-30 \mathrm{seg}$

1 ciclo 20 ciclos

1 ciclo

Solução de acrilamida (19:1) $40 \%$

Acrilamida

$38 \% \mathrm{p} / \mathrm{v}$

Bis-acrilamida

$2 \% \mathrm{p} / \mathrm{v}$

$\mathrm{H}_{2} \mathrm{O}$ (destilada)

q.S.V.

Dissolver a acrilamida e a bis-acrilamida em cerca de $90 \%$ do volume final de água destilada. Adicionar $5 \mathrm{~g}$ de resina para deionização. Agitar em agitador magnético por até 10 minutos. Filtrar em filtro com diâmetro médio de poros de $2 \mu \mathrm{m}$, com bomba de vácuo. Ajustar o volume final com água destilada. Guardar na geladeira. Estável por até um mês.

Gel desnaturante de acrilamida $4 \%$

Uréia

Solução de acrilamida (19:1) $40 \%$
$36 \% \mathrm{p} / \mathrm{v}$

$10 \% \mathrm{v} / \mathrm{v}$ 
TBE $10 x$

Solução de persulfato de amônio $10 \%$

TEMED

$\mathrm{H}_{2} \mathrm{O}$ (destilada)
$10 \% \mathrm{v} / \mathrm{v}$

$5 \% \mathrm{v} / \mathrm{v}$

$7 \% \mathrm{v} / \mathrm{v}$

q.S.v.

Dissolver inicialmente a uréia e a solução de acrilamida em cerca de $50 \%$ do volume final de água destilada, juntamente com $1 \% \mathrm{p} / \mathrm{v}$ de resina deionizante. Agitar em agitador magnético por 15 minutos. Filtrar e acrescentar o TBE e completar o volume com água destilada. Acrescentar, no momento de usar, a solução de persulfato de amônio 10\% e o TEMED. Agitar o frasco suavemente para evitar a formação de bolhas. O tempo de deionização deve ser controlado rigidamente, assim como os outros procedimentos, para permitir a padronização dos géis. A solução de persulfato de amônio deve ser preparada no momento do uso.

A mistura, ainda líquida, deve ser aplicada com seringa no molde adequado, com pente para formação das canaletas onde serão aplicadas as amostras de DNA. Aguardar a catalização da acrilamida por no minimo 2 horas e no máximo 6 horas.

\subsubsection{Metodologia para obtenção de bandas de AFLP}

(Vos et al., 1995; Zabeau \& Vos, 1993)

DNA de cada uma das variedades de mandioca, extraído segundo metodologia descrita acima e conservado $\mathrm{a}-20^{\circ} \mathrm{C}$, foi quantificado em fluorimetro e diluído em TE até uma concentração aproximada de 15 e $30 \mathrm{ng} / \mu \mathrm{l}$.

A seguir o DNA foi digerido pelas as enzimas de restrição EcoRI e MseI. A reação de digestão foi feita a $37^{\circ} \mathrm{C}$, por duas horas, em tubos de polipropileno tipo "eppendorff" com capacidade para $0,2 \mathrm{ml}$, usando um termociclador para manter a temperatura estável.

A seguir, aos mesmos tubos foram acrescentados os demais reagentes necessários à ligação dos fragmentos clivados aos adaptadores, complementares às extremidades clivadas pelas duas enzimas. A reação de ligação foi feita a $37^{\circ} \mathrm{C}$, por uma hora, usando um termociclador para manter a temperatura estável 
O DNA clivado e ligado aos adaptadores foi pré-amplificado e uma alíquota de $10 \mu l$ do resultado foi utilizada para avaliar a qualidade da clivagem e amplificação. Para isso foi submetida a eletroforese em gel de agarose $1 \%$, por 3 horas em TBE $1 \times$, a 3 $\mathrm{V} / \mathrm{cm}$. Após coloração com brometo de etídeo, observou-se a formação de um rastro de DNA clivado.

O DNA pré-amplificado foi diluído 20 vezes em água destilada e submetido a amplificação seletiva. Foram testados 10 pares de iniciadores e escolhidos 4 por produzirem padrões de bandas adequados para análise e com maior polimorfismo: MseACA/Eco-CTC, Mse-ACA/Eco-CAG, Mse-ACT/Eco-CAC e Mse-AGG/Eco-CAA.

As amostras de DNA amplificadas, assim como as amostras remanescentes das fases anteriores do processo, foram conservadas a $-20^{\circ} \mathrm{C}$.

Os componentes da reação de clivagem, ligação, pré-amplificação e amplificação seletiva, assim como os parâmetros de temperatura e duração dos ciclos dos programas para as amplificações em termocicladores, estão especificados abaixo.

O DNA amplificado foi submetido a eletroforese em gel desnaturante de acrilamida (19:1) a $4 \%$, para separação dos fragmentos segundo seu peso molecular. A eletroforese foi feita em equipamento $\mathrm{ABI}$ Prism 377, a $50^{\circ} \mathrm{C}$, por 3 horas, a 3000 volts, com tampão TBE $1 \mathrm{x}$. Foi usada uma matriz de gel previamente preparada no CIAT, foi utilizado o filtro A e o módulo A 2400. Foram usados pentes com dentes retangulares e moldes para géis verticais de $36 \mathrm{~cm}$.

Para aplicação no gel, alíquotas de 2,0 $\mu 1$ do DNA amplificado foram misturadas com $0,5 \mu$ do marcador de peso molecular e $2,5 \mu \mathrm{l}$ de uma solução $5: 1$ de formamida deionizada e Blue Dextran 50mg/ml em EDTA $25 \mathrm{mM} \mathrm{pH} \mathrm{8,0.} \mathrm{Imediatamente} \mathrm{antes} \mathrm{da} \mathrm{aplica-}$ ção, estas amostras foram desnaturadas por 2 minutos a $95^{\circ} \mathrm{C}$ e a seguir mantidas em recipiente com gelo.

Como padrão para cálculo de peso molecular das bandas, foi usado o marcador fluorescente TAMRA 350 fornecido pela Perkin-Elmer.

As imagens dos géis, digitalizadas pelo programa GeneScan, foram transformadas em gráficos, com picos representando as bandas. A análise dos gráficos foi feita com o programa Genotyper. 
A Figura 7 mostra um exemplo de gráficos usados para identificação de bandas de AFLP.

Componentes da reação de clivagem de DNA com enzimas de restrição

Enzima EcoRI

Enzima MseI

Solução tampão $10 \times$ concentrada $10 \% \mathrm{v} / \mathrm{v}$

DNA $100-200 \mathrm{ng}$

$\mathrm{H}_{2} \mathrm{O}$ (destilada)

q.s.v.

Total $25 \mu 1$

Componentes da reação de ligação do DNA com extremidades adaptadoras

T4 DNA ligase

Solução tampão $10 \times$ concentrada

Adaptadores EcoRI

Adaptadores Msel

ATP

DTT

Solução de DNA clivado

$\mathrm{H}_{2} \mathrm{O}$ (destilada)

Total
$6 \mathrm{U}$ $10 \% \mathrm{v} / \mathrm{v}$

$1 \mu l$

$1 \mu 1$

$0,4 \mathrm{mM}$

$2,5 \mathrm{mM}$

$25 \mu 1$

q.s.v.

$50 \mu 1$

Componentes da reação de pré-amplificação de DNA - AFLP

Iniciadores para pré-amplificação ("kit" Perkin-Elmer) $\quad 1 \mu \mathrm{l}$

DNA clivado e ligado a adaptadores $\quad 1 \mu \mathrm{l}$

Mistura para pré-amplificação ("kit" Perkin-Elmer) $15 \mu \mathrm{l}$

$\mathrm{H}_{2} \mathrm{O}$ (destilada) $\quad 3 \mu \mathrm{l}$

Total

$20 \mu \mathrm{l}$ 


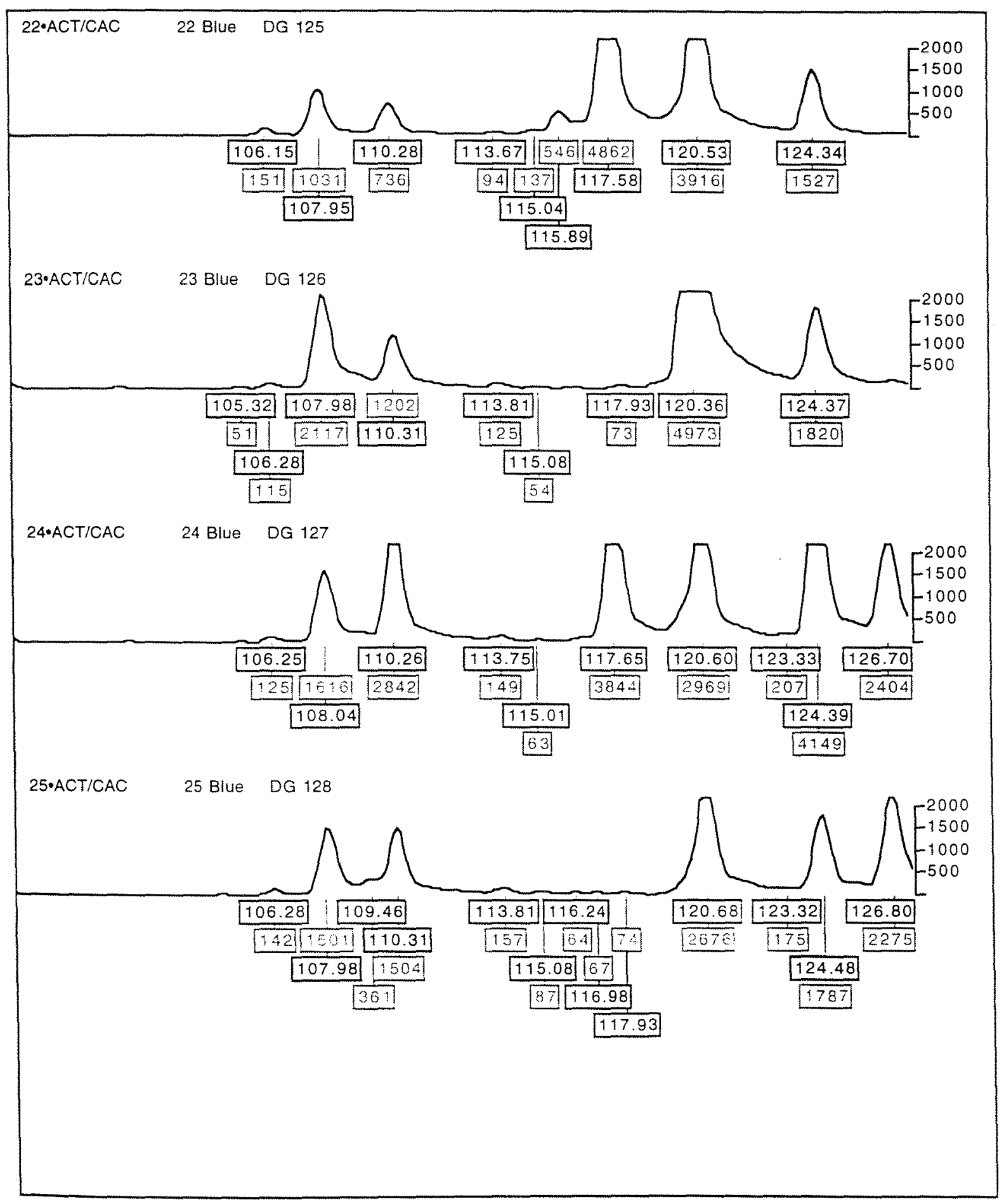

Figura 7 - Gráficos representando as bandas de AFLP 
Componentes da reação de amplificação seletiva de DNA - AFLP

iniciadores EcoRI ("kit" Perkin-Elmer)

$1 \mu 1$

iniciadores Msel ("kit" Perkin-Elmer)

$1 \mu 1$

DNA pré-amplificado diluído 1:20

$3 \mu 1$

Mistura para amplificação ("kit" Perkin-Elmer)

$15 \mu 1$

Total

$20 \mu \mathrm{l}$

Programa para pré-amplificação de DNA em termociclador - AFLP

$94^{\circ} \mathrm{C}-2 \mathrm{~min}$

$94^{\circ} \mathrm{C}-1$ seg

$69^{\circ} \mathrm{C}-30 \mathrm{~min}$

$56^{\circ} \mathrm{C}-30 \mathrm{seg} \quad 72^{\circ} \mathrm{C}-2 \mathrm{~min}$

1 ciclo

23 ciclos

1 ciclo

Programa para amplificação seletiva de DNA em termociclador - AFLP

$\begin{array}{lcll}94^{\circ} \mathrm{C}-2 \mathrm{~min} & 65^{\circ} \mathrm{C}-30 \mathrm{seg} & 72^{\circ} \mathrm{C}-2 \mathrm{~min} & 1 \text { ciclo } \\ 94^{\circ} \mathrm{C}-1 \mathrm{seg} & 64^{\circ} \mathrm{C}-30 \mathrm{seg} & 72^{\circ} \mathrm{C}-2 \mathrm{~min} & 1 \text { ciclo } \\ 94^{\circ} \mathrm{C}-1 \mathrm{seg} & 63^{\circ} \mathrm{C}-30 \mathrm{seg} & 72^{\circ} \mathrm{C}-2 \mathrm{~min} & 1 \text { ciclo } \\ 94^{\circ} \mathrm{C}-1 \mathrm{seg} & 62^{\circ} \mathrm{C}-30 \mathrm{seg} & 72^{\circ} \mathrm{C}-2 \mathrm{~min} & 1 \text { ciclo } \\ 94^{\circ} \mathrm{C}-1 \mathrm{seg} & 61^{\circ} \mathrm{C}-30 \mathrm{seg} & 72^{\circ} \mathrm{C}-2 \mathrm{~min} & 1 \text { ciclo } \\ 94^{\circ} \mathrm{C}-1 \mathrm{seg} & 60^{\circ} \mathrm{C}-30 \mathrm{seg} & 72^{\circ} \mathrm{C}-2 \mathrm{~min} & 1 \text { ciclo } \\ 94^{\circ} \mathrm{C}-1 \mathrm{seg} & 59^{\circ} \mathrm{C}-30 \mathrm{seg} & 72^{\circ} \mathrm{C}-2 \mathrm{~min} & 1 \text { ciclo } \\ 94^{\circ} \mathrm{C}-1 \mathrm{seg} & 58^{\circ} \mathrm{C}-30 \mathrm{seg} & 72^{\circ} \mathrm{C}-2 \mathrm{~min} & 1 \text { ciclo } \\ 94^{\circ} \mathrm{C}-1 \mathrm{seg} & 57^{\circ} \mathrm{C}-30 \mathrm{seg} & 72^{\circ} \mathrm{C}-2 \mathrm{~min} & 1 \text { ciclo } \\ 94^{\circ} \mathrm{C}-1 \mathrm{seg} & 56^{\circ} \mathrm{C}-30 \mathrm{seg} & 72^{\circ} \mathrm{C}-2 \mathrm{~min} & 23 \text { ciclos } \\ 69^{\circ} \mathrm{C}-30 \mathrm{~min} & - & - & 1 \text { ciclo }\end{array}$

\subsubsection{Análise dos dados}

\section{Presença e ausência de bandas}

As bandas dos géis de RAPD foram computadas como presença e ausência e registradas em tabelas com 1 representando presença e 0 representando ausência.

As bandas dos géis de AFLP foram transformadas em picos, em gráficos gerados pelo programa GENOTYPER. Os picos foram computados como presença e ausência e registrados em tabelas de presença/ausência como para RAPD. 
As bandas dos géis de microssatélites também foram transformadas em picos, em gráficos gerados pelo programa GENOTYPER e igualmente registrados em tabelas de presença/ausência.

As bandas geradas por microssatélites foram analisadas de duas maneiras: 1) como bandas independentes, sem relação de alelismo entre os fragmentos, da mesma forma que as bandas de RAPD e AFLP. Para este caso será usado do termo banda; 2) como alelos múltiplos de locos distintos. Neste caso, será usado o termo alelo e as bandas que contém dois alelos iguais de indivíduos homozigotos, foram contadas em dobro.

\section{Similaridade e distância genética entre variedades de mandioca}

Similaridade genética entre variedades de mandioca, duas a duas, foi estimada pelo coeficiente proposto por Nei \& Li (1979) a partir do algoritmo da Equação 1. Este índice foi escolhido porque não inclui as bandas ausentes nas duas variedades comparadas e dá maior peso às bandas que são compartilhadas pelos indivíduos comparados.

$S_{\mathrm{ij}}=2 \mathrm{a} /(2 \mathrm{a}+\mathrm{b}+\mathrm{c})$

sendo:

$\mathrm{S}=$ similaridade

i e $j$ as duas variedades de mandioca comparadas

$\mathrm{a}=$ bandas presentes em $\mathrm{i}$ e $\mathrm{j}$

$\mathrm{b}=$ bandas presentes apenas em $\mathrm{i}$

$\mathrm{c}=$ bandas presentes apenas $\mathrm{em} \mathbf{j}$

Distâncias genéticas foram estimadas como sendo :

$\mathrm{D}_{\mathrm{ij}}=1-\mathrm{S}_{\mathrm{ij}}$

Foram computadas todas as bandas, tanto polimórficas como monomórficas. Alguns trabalhos utilizam somente bandas polimórficas para cálculo de similaridade e de distância. Isso melhora a resolução de dendrogramas feitos a partir destes índices e 
reduz o número de dados manipulados nos programas estatísticos sem alterar as diferenças relativas de similaridade. Mas também resulta numa subestimação dos valores absolutos da similaridade e dificulta a comparação entre diferentes trabalhos.

O cálculo dos índices de similaridade foram feitos usando o programa NTSYS (Rolf, 1992).

Existem outros índices de similaridade, baseados em outros algoritmos, muito freqüentemente usados em trabalhos com marcadores de DNA. O índice de Jaccard (Equação 3), assim como o indice de Nei \& Li, também não considera bandas ausentes no cálculo de similaridade entre dois individuos. Num teste comparativo inicial, o índice de Jaccard produziu valores de similaridade ligeiramente menores que o índice de Nei \& Li mas deu resultado idêntico no que se refere aos agrupamentos. A opção pelo índice de Nei \& Li e não de Jaccard foi arbitrária.

$\mathrm{S}_{\mathrm{ij}}=\mathrm{a} /(\mathrm{a}+\mathrm{b}+\mathrm{c})$

O índice baseado em Concordância Simples (do inglês = "simple matching") (Equação 4), inclui todas as bandas detectadas para o conjunto de indivíduos amostrados, nas comparações dois a dois, mesmo que elas não estejam presentes em nenhum destes dois indivíduos. A ausência de uma banda em dois indivíduos é considerada um indicador de similaridade igual à presença de duas bandas nestes dois individuos. No entanto a ausência de uma banda pode ser devida a causas diversas e dois indivíduos podem não ter esta banda por motivos diferentes, portanto compartilhar uma ausência não seria sinal de similaridade. Por esse motivo, não foi usado este índice.

$S_{i j}=(a+d) /(a+b+c+d)$

sendo:

$\mathrm{S}=$ similaridade

i e $\mathrm{j}$ as duas variedades de mandioca comparadas

$\mathrm{a}=$ bandas presentes em $\mathrm{i}$ e $\mathrm{j}$ 
$b=$ bandas presentes apenas em $i$

$\mathrm{c}=$ bandas presentes apenas $\mathrm{em} \mathrm{j}$

$\mathrm{d}=$ bandas ausentes em $\mathrm{i}$ e $\mathrm{j}$

O índice $\mathrm{D}_{\mathrm{AS}}$ (Chakraborty \& Jin, 1993), foi sugerido para cálculos de similaridade quando se usa microssatélites. Para estes cálculos, comparam-se dois indivíduos loco a loco. Se os dois alelos no loco forem iguais, a similaridade no loco é igual a 1 . Se apenas um alelo for igual nos dois indivíduos, o valor atribuído de similaridade é $0,5 \mathrm{e}$ se nenhum dos alelos for igual, o valor será zero. A similaridade entre os indivíduos é dada pela média de todos os locos.

Testes iniciais indicaram resultados muito semelhantes aos obtidos com os indices de Nei \& Li e Jaccard. A magnitude de valores de $\mathrm{D}_{\mathrm{AS}}$ foi intermediária entre os outros dois. Não houve alteração dos dendrogramas. Como é um indice para ser usado apenas com marcadores codominantes foi dada preferência para o índice de $\mathrm{Nei} \& \mathrm{Li}$, para facilitar a comparação entre resultados de microssatélites, RAPD e AFLP.

Foram geradas matrizes de similaridade para os três tipos de marcadores de DNA separadamente. Comparações entre matrizes foram feitas usando o método não paramétrico de Spearman, que usa a ordenação dos valores para estabelecer as correlações. Foi escolhido este método porque o tipo de distribuição dos valores de similaridade não é conhecida.

No entanto, a maioria dos trabalhos de avaliação de diversidade com marcadores de DNA utiliza o momento-produto ( $\mathrm{r}$ ) para comparar matrizes de distância ou similaridade. Apesar deste método pressupor a distribuição normal dos dados, para efeito de comparação com resultados de outros autores, os valores de $r$ também serão apresentados.

Todos os cálculos foram feitos no programa EXCEL.

\section{Dendrogramas}

A partir das matrizes de distância foram feitos dendrogramas pelo método de agrupamento hierárquico (SAHN) por pares de médias não ponderadas (UPGMA) (Sneath \& Sokal, 1973). 
Como os indices de distância encontrados foram baixos, sobretudo para RAPD e AFLP, para melhorar o aspecto dos dendrogramas, foram feitas adaptações nas escalas gráficas utilizadas.

Foi calculada a correlação cofenética para cada dendrograma, a fim de estabelecer o grau de adequação da representação gráfica dos agrupamentos em relação às matrizes de distância originais.

Todos os cálculos foram feitos com o auxílio do programa NTSYS (Rolf, 1992) e os gráficos com o programa STATISTICA (STATSOFT Inco., 1996)

\section{Análise de coordenadas principais $(\operatorname{PCoA})$}

A representação gráfica da dispersão das variedades de mandioca em função de coordenadas principais, estabelecidas a partir das matrizes de distância, foi preparada com o programa STATISTICA (STATSOFT Inco, 1996).

A determinação dos novos "escores", dos autovetores, autovalores e da porcentagem de variação representada pelas novas variáveis independentes (coordenadas principais) foi feita com o programa FITOPAC, desenvolvido por George John Shepherd da Universidade Estadual de Campinas (UNICAMP).

\section{Índices de diversidade}

Para os locos de microssatélites foram estimados índices de diversidade (ID). Estes índices reúnem, em um único valor, informações de número de alelos e freqüência alélica.

O ID freqüentemente é apresentado na forma de $\mathrm{H}$ (heterozigozidade), quando se trata de estudos populacionais em que a freqüência alélica pode ser relacionada à proporção de heterozigotos na população. Como no presente estudo, não estamos estimando parâmetros populacionais, foi adotada a terminologia indice de diversidade (Weir, 1990).

$\mathrm{ID}=1-\sum \mathrm{p}_{\mathrm{i}}^{2}$ 
Sendo $p_{i}$ a freqüência do iésimo alelo no grupo de plantas avaliado.

Distribuição da diversidade genética entre e dentro de grupos de variedades de mandioca

Foi estimada a variabilidade genética dentro de grupos, pela média das distâncias entre plantas de um mesmo grupo. A variabilidade genética entre grupos foi estimada pela média das distâncias entre as plantas de grupos diferentes (Chalmers et al., 1992).

Foram feitos cálculos separados para cada tipo de marcador de DNA utilizado.

Para os dados de microssatélites também foi calculado o coeficiente de diferenciação genética $\mathrm{G}_{\mathrm{ST}}(\mathrm{Nei}, 1973)$. Neste caso, as bandas geradas por cada par de iniciadores foram analisadas como alelos, para cada um dos 11 locos.

O coeficiente de diferenciação genética para um loco é dado por:

$\mathrm{G}_{\mathrm{ST}}=1-\left(\mathrm{H}_{\mathrm{S}} / \mathrm{H}_{\mathrm{T}}\right)$

Sendo $\mathrm{H}_{\mathrm{T}}$ a diversidade total no loco para todas as plantas analisadas, calculada pela equação:

$\mathrm{H}_{\mathrm{T}}=1-\sum \mathrm{p}_{\mathrm{i}}^{2}$

onde $\mathrm{p}_{\mathrm{i}}$ é a freqüência do iésimo alelo no total de plantas analisadas.

$\mathrm{E}$ sendo $\mathrm{H}_{S}$ a diversidade média em um loco dentro dos grupos de plantas, calculada pela equação:

$\mathrm{H}_{\mathrm{S}}=\sum \mathrm{nh}_{\mathrm{S}} / \mathrm{N}$

onde $\mathrm{n}$ é o número de plantas do grupo, $\mathrm{N}$ é o número total de plantas e $\mathrm{h}_{\mathrm{S}}$ é a diversidade encontrada em um loco em um grupo de plantas, dada pela equação:

$h_{S}=2 n\left(1-\sum p_{i}^{2}\right) / 2 n-1$ 
onde $\mathrm{n}$ é o número de plantas do grupo e $\mathrm{p}_{\mathrm{i}}$ é a freqüência do iésimo alelo deste loco dentro do grupo. Esta equação foi utilizada, por propiciar a ponderação das freqüências alélicas de cada grupo em função dos diferentes valores de n e por incluir um fator de correção de desvio em função do pequeno número de indivíduos nos grupos (Nei, 1973).

Todos os cálculos foram feitos no programa EXCEL.

Slatkin (1995) e Goodman (1997), propuseram uma variante, Rst, para o cálculo da distribuição da variabilidade em função de dados de microssatélites. Além de considerar a freqüência alélica, incorporaram a informação da variação do número de repetições contidas no microssatélite para estimar distâncias genéticas. Quanto maior a diferença no número de unidades repetitivas entre dois alelos, maior seria a distância genética entre os individuos portadores destes alelos.

Essa abordagem está apoiada no modelo de evolução chamado mutação passo a passo (do inglês "stepwise mutation"), para os microssatélites, em que as alterações se dão sempre por acréscimo ou eliminação de uma única unidade repetitiva em cada evento (Valdes et al., 1993; Shriver et al., 1993).

No entanto essa metodologia implica no conhecimento das seqüências flanqueadoras e da composição do microssatélite. Estas informações não estavam disponiveis para os microssatélites utilizados neste trabalho.

Além disso, vem sendo demonstrado que não apenas alterações no número de elementos repetitivos causa variações alélicas mas também mutações de ponto e alterações nas regiões flanqueadoras, o que torna necessária uma certa cautela na adoção da estatística Rst (Samadi et al, 1998; Kruglyak et al., 1998; Chakraborty et al., 1997; Dermitzakis et al., 1998; Nauta \& Weissing, 1996). 


\section{RESULTADOS E DISCUSSÃO}

\subsection{Considerações gerais}

A caracterização das 55 variedades de mandioca por meio dos 3 tipos de marcadores de DNA se iniciará com uma descrição detalhada dos padrões de bandas obtidos segundo a metodologia descrita no capitulo 3.

O termo bandas, neste trabalho, refere-se primariamente aos sinais discretos que se formam em géis de agarose ou acrilamida após os procedimentos de eletroforese para separação de fragmentos de DNA.

Por extensão, o termo banda pode referir-se aos fragmentos de DNA que originam a formação da banda no gel. Neste sentido, diz-se que uma planta possui determinada banda quando fragmentos de seu DNA produzem esta banda no gel.

As bandas são identificadas pela posição relativa que ocupam no gel.

Assume-se que na região do gel em que ser delineia uma banda estejam reunidos fragmentos de DNA com mesmo comportamento eletroforético, mesmo comprimento e mesmo peso molecular.

No caso dos microssatélites, assume-se que em uma banda estejam agrupados os fragmentos de DNA correspondentes a um alelo. Neste caso, uma banda corresponde a um alelo. Note-se que, em individuos homozigotos para um loco, os dois alelos iguais estarão contidos na mesma banda.

Como já foi mencionado no capítulo Material e Métodos, as bandas geradas por microssatélites foram analisadas de duas maneiras: 1) - como bandas independentes, sem relação de alelismo entre os fragmentos, da mesma forma que as bandas de RAPD e AFLP. Para este caso, será usado do termo banda; 2) - como alelos múltiplos de locos distintos. Neste caso, será usado o termo alelo. 


\subsection{Distribuição geral das bandas de RAPD, AFLP e microssatélites}

\section{Número de bandas analisadas}

Foram analisadas 339 bandas, sendo 134 de AFLP, 156 de RAPD e 49 de microssatélites. As tabelas com a identificação das bandas, para cada tipo de marcador e segundo sua presença ou ausência para as 55 plantas estudadas, estão nos Anexos 1 a 3 .

\section{Bandas polimórficas e monomórficas}

A primeira distinção que se pode fazer é entre bandas polimórficas e monomórficas. São chamadas polimórficas, as bandas que apresentam dois estados: presente ou ausente. São chamadas monomórficas as bandas que apresentam apenas um estado: estão sempre presentes. A proporção de bandas polimórficas e monomórficas pode ser vista na Tabela 3.

Os marcadores que apresentaram maior polimorfismo foram os microssatélites, com $97,96 \%$ de bandas polimórficas, seguidos dos marcadores de AFLP, com $69,40 \% \mathrm{e}$ por último os marcadores de RAPD, com 55,80\%.

\section{Freqüência das bandas polimórficas}

Freqüência, refere-se à porcentagem de indivíduos analisados que apresentam a banda. A Tabela 4 resume a informação: as bandas foram agrupadas em intervalos de freqüência para facilitar a análise.

Observa-se que os microssatélites apresentaram a maior proporção de bandas de baixa freqüência: $25 \%$ das bandas polimórficas têm frequêencia menor que $10 \%$. Para os marcadores de AFLP e RAPD, as bandas com baixa freqüência representam $10 \%$ e $8 \%$ do total de bandas polimórficas, respectivamente.

Os marcadores de AFLP apresentaram a maior incidência de bandas de alta freqüência: $32 \%$ do total de bandas polimórficas está presente em mais de $80 \%$ das variedades de mandioca. Quanto aos marcadores de RAPD, 23\% das bandas polimórficas está presente em mais de $80 \%$ das variedades de mandioca. Os microssatélites têm apenas $8 \%$ das bandas polimórficas com freqüência superior a $80 \%$. 
Tabela 3 - Proporção de bandas polimórficas e monomórficas

\begin{tabular}{|l|r|r|r|r|r|r|}
\hline \multirow{2}{*}{$\begin{array}{l}\text { Tipo de } \\
\text { Marcador }\end{array}$} & \multicolumn{2}{|c|}{ Monomórficas } & \multicolumn{2}{c|}{ Polimórficas } & \multicolumn{2}{c|}{ TOTAL } \\
\cline { 2 - 7 } & $\begin{array}{c}\text { Número } \\
\text { de bandas }\end{array}$ & $\%$ & $\begin{array}{c}\text { Número } \\
\text { de bandas }\end{array}$ & $\%$ & $\begin{array}{c}\text { Número } \\
\text { de bandas }\end{array}$ & $\%$ \\
\hline RAPD & 69 & 44,20 & 87 & 55,80 & $\mathbf{1 5 6}$ & $\mathbf{1 0 0 , 0 0}$ \\
\hline AFLP & 41 & 30,60 & 93 & 69,40 & $\mathbf{1 3 4}$ & $\mathbf{1 0 0 , 0 0}$ \\
\hline Microssatélites & 1 & 2,04 & 48 & 97,96 & $\mathbf{4 9}$ & $\mathbf{1 0 0 , 0 0}$ \\
\hline TOTAL & $\mathbf{1 1 1}$ & $\mathbf{3 2 , 7 0}$ & $\mathbf{2 2 8}$ & $\mathbf{6 7 , 3 0}$ & $\mathbf{3 3 9}$ & $\mathbf{1 0 0 , 0 0}$ \\
\hline
\end{tabular}

Tabela 4 - Distribuição das bandas polimórficas segundo sua freqüência *

\begin{tabular}{|c|c|c|c|c|c|c|c|c|}
\hline \multirow{2}{*}{$\begin{array}{c}\text { Intervalos } \\
\text { de freqüência } \\
\text { das bandas }\end{array}$} & \multicolumn{2}{|c|}{ RAPD } & \multicolumn{2}{|c|}{ AFLP } & \multicolumn{2}{|c|}{ Microssatélites } & \multicolumn{2}{|c|}{ TOTAL } \\
\hline & $\begin{array}{c}\text { Número } \\
\text { de bandas }\end{array}$ & $\%$ & $\begin{array}{c}\text { Número } \\
\text { de bandas }\end{array}$ & $\%$ & $\begin{array}{c}\text { Número } \\
\text { de bandas }\end{array}$ & $\%$ & $\begin{array}{c}\text { Número } \\
\text { de bandas }\end{array}$ & $\%$ \\
\hline$>0-9$ & 7 & 8.05 & 9 & 9.68 & 12 & 25,00 & 28 & 12,28 \\
\hline 10-19 & 11 & 12,64 & 13 & 13,98 & 5 & 10,42 & 29 & 12,72 \\
\hline 20-29 & 15 & 17,24 & 5 & 5.38 & 9 & 18,75 & 29 & 12,72 \\
\hline $30-39$ & 9 & 10,34 & 11 & 11.83 & 5 & 10,42 & 25 & 10,96 \\
\hline $40-49$ & 5 & 5,75 & 5 & 5,38 & 6 & 12.50 & 16 & 7,02 \\
\hline $50-59$ & 4 & 4,60 & 11 & 11,83 & 2 & 4,17 & 17 & 7,46 \\
\hline $60-69$ & 8 & 9,20 & 5 & 5,38 & ] & 2,08 & 14 & 6,14 \\
\hline $70-79$ & 8 & 9,20 & 4 & 4,30 & 4 & 8,33 & 16 & 7,02 \\
\hline $80-89$ & 13 & 14,94 & 16 & 17.20 & 2 & 4,17 & 31 & 13,60 \\
\hline $90-99$ & 7 & 8,05 & 14 & 15,05 & 2 & 4,17 & 23 & 10,09 \\
\hline TOTAL & 87 & 100,00 & 93 & 100,00 & 48 & 100,00 & 228 & 100,00 \\
\hline
\end{tabular}

* Frequéncia $=\%$ de individuos que apresentam a banda.

Tabela 5 - Bandas ausentes nos grupos de variedades de mandioca

\begin{tabular}{|c|c|c|c|c|c|c|c|c|c|}
\hline \multirow[t]{3}{*}{ Regiāo/Tipo } & \multicolumn{2}{|c|}{ RAPD } & \multicolumn{2}{|c|}{$\overline{A F L P}$} & \multicolumn{2}{|c|}{ Microssatélites } & \multicolumn{2}{|c|}{ TOTAL } & \multirow[t]{3}{*}{$n^{*}$} \\
\hline & \multirow{2}{*}{$\begin{array}{l}\text { Número } \\
\text { de bandas }\end{array}$} & \multirow[t]{2}{*}{$\%$} & \multirow{2}{*}{$\begin{array}{l}\text { Número } \\
\text { de bandas }\end{array}$} & \multirow[t]{2}{*}{$\%$} & \multirow{2}{*}{$\begin{array}{l}\text { Número } \\
\text { de bandas }\end{array}$} & \multirow[t]{2}{*}{$\%$} & \multirow{2}{*}{$\begin{array}{l}\text { Número } \\
\text { de bandas }\end{array}$} & \multirow[t]{2}{*}{$\%$} & \\
\hline & & & & & & & & & \\
\hline Vale do Ribeira & 21 & 13,46 & 17 & 12,69 & 18 & 36,73 & 56 & 16,52 & 9 \\
\hline AMAZÓNIA & 1 & 0.64 & 1 & 0,75 & 0 & 0,00 & 2 & 0,59 & 45 \\
\hline Rio Solimōes & 6 & 3,85 & 11 & 8,21 & 11 & 22,45 & 28 & 8,26 & 16 \\
\hline Rio Branco & 9 & 5,77 & 13 & 9,70 & 14 & 28,57 & 36 & 10,62 & 6 \\
\hline Rio Negro & 5 & 3,21 & 2 & 1,49 & 6 & 12,24 & 13 & 3,83 & 23 \\
\hline & & & & & & & & & \\
\hline Aipins & 13 & 8,33 & 10 & 7,46 & 17 & 34,69 & 40 & 11,80 & 17 \\
\hline Bravas & 2 & 1,28 & 3 & 2,24 & 1 & 2,04 & 6 & 1,77 & 38 \\
\hline
\end{tabular}

${ }^{*} \mathrm{n}=$ número de plantas por grupo de variedades de mandioca 


\subsection{Distribuição das bandas por grupos de variedades de mandioca}

Serão usados dois critérios para agrupamento das variedades de mandioca, por local de origem e por tipo. Quanto aos locais de origem, são quatro, os grupos: Rio Negro, Rio Branco, Rio Solimões e Litoral Sul do Estado de São Paulo.

Quanto aos tipos, são dois grupos: aipins (ou macaxeiras) e as demais variedades (que serão denominadas, neste trabalho, mandiocas bravas). Esta classificação foi feita a partir dos nomes das variedades. É possível que algumas plantas classificadas como mandiocas bravas sejam, na realidade, aipins ou macaxeiras.

\section{Total de bandas e bandas ausentes, por grupo de variedades de mandioca}

Analisando a presença e ausência das bandas dentro dos grupos de variedades de mandioca, de diferentes regiões de origem, observa-se que nem todas as bandas estão presentes em todos os grupos. A Tabela 5 indica que a ausência de bandas é mais acentuada no grupo de plantas do Litoral de São Paulo. Das 339 bandas analisadas, 56 estão ausentes neste grupo (cerca de 17\%).

O conjunto de plantas oriundas da Amazônia apresenta praticamente todas as bandas analisadas, faltando apenas 2 bandas ( $1 \%$ ). Dentro deste conjunto de plantas, o grupo do Rio Branco tem maior proporção de bandas ausentes: $11 \%$ do total de bandas. O grupo do Rio Negro é o que apresenta menor freqüência de bandas ausentes, apenas $4 \%$ do total. O grupo do Rio Solimões tem um valor intermediário de bandas ausentes: $8 \%$ do total.

As proporções de bandas ausentes são maiores para bandas de microssatélites, com $37 \%$ de bandas ausentes nas variedades do Litoral de São Paulo, 29\% no grupo do Rio Branco, $22 \%$ do Rio Solimões e $12 \%$ do Rio Negro.

É de se esperar que nos grupos que têm menos variedades, sejam encontradas menos bandas, mas é de se notar que o grupo do Rio Branco, com apenas 6 variedades, apresenta sempre mais bandas que o grupo de Litoral de São Paulo, com 9 variedades de mandioca.

Quanto às diferenças entre aipins e mandioca bravas, como seria de esperar, o grupo de 38 mandiocas bravas apresenta muito mais bandas que o grupo de 17 aipins. 
Apesar da diferença na magnitude dos valores, os resultados obtidos com cada tipo de marcador são equivalentes, na comparação entre grupos de variedades de mandioca.

\section{Bandas polimórficas e monomórficas, por grupo de variedades de mandioca}

Dentre as bandas presentes em cada grupo de variedades de mandioca, a proporção de bandas polimórficas e monomórficas está apresentada na Tabela 6 . Observa-se que, em relação às regiões de origem, as plantas do grupo do Litoral de São Paulo contam com menor proporção de bandas polimórficas: $47 \%$ do total de bandas presentes. Dentre as variedades da Amazônia, o grupo do Rio Negro apresenta maior proporção de bandas polimórficas ( $62 \%$ das bandas presentes), seguido do grupo do Rio Solimões $(58 \%)$ e do Rio Branco (51\%). Estas observações também são válidas para cada um dos três tipos de marcador, se tomados isoladamente.

Em relação às mandiocas bravas e aipins, 57\% e 65\% das bandas são polimórficas respectivamente, sendo que, esta diferença se mantém, examinando cada marcador separadamente.

\section{Freqüência das bandas polimórficas, por grupo de variedades de mandioca}

A distribuição das bandas polimórficas segundo sua freqüência, em cada um dos grupos, é dada na Tabela 7. Em relação aos grupos de diferentes regiões de origem, observa-se que não há bandas de muito baixa freqüência (freqüência $<10 \%$ ) nos grupos do Litoral de São Paulo e do Rio Branco. Para as variedades do Rio Solimões, 9\% das bandas polimórficas têm freqüência menor que $10 \%$ e para o Rio Negro $16 \%$ das bandas são de baixa freqüência. Para o conjunto de plantas da Amazônia, 14\% das bandas têm freqüência inferior a $10 \%$.

Analisando as bandas de microssatélites separadamente, pode-se observar um grande contraste de freqüência das bandas entre os grupos. Se juntarmos as bandas com menos de $30 \%$ de freqüência, veremos que elas representam apenas $16 \%$ das bandas no grupo de variedades do Litoral de São Paulo e 52\% para as plantas da Amazônia. Este forte contraste também existe entre aipins e mandiocas bravas, para as quais a 
Tabela 6 - Proporção de bandas monomórficas e polimórficas, por grupo de variedades de mandioca

\begin{tabular}{|c|c|c|c|c|c|c|}
\hline \multirow[t]{2}{*}{ Região/Tipo } & \multicolumn{6}{|c|}{ TOTAL } \\
\hline & Monomórficas & $\%$ & Polimórficas & $\%$ & Total & $\%$ \\
\hline Litoral SP & 149 & 52,65 & 134 & 47,35 & 283 & 100,00 \\
\hline AMAZÓNIA & 113 & 33,53 & 224 & 66,47 & 337 & 100,00 \\
\hline Rio Solimões & 130 & 41,80 & 181 & 58.20 & 311 & 100,00 \\
\hline Rio Branco & 149 & 49,17 & 154 & 50,83 & 303 & 100,00 \\
\hline Rio Negro & 123 & 37.73 & 203 & 62.27 & 326 & 100,00 \\
\hline Aipins & 130 & 43.48 & 169 & 56,52 & 299 & 100,00 \\
\hline Bravas & 115 & 34,53 & 218 & 65,47 & 333 & 100,00 \\
\hline
\end{tabular}

\begin{tabular}{|c|c|c|c|c|c|c|}
\hline \multirow[t]{2}{*}{ Região/Tipo } & \multicolumn{6}{|c|}{ RAPD } \\
\hline & Monomórficas & $\%$ & Polimórficas & $\%$ & Total & $\%$ \\
\hline Litoral SP & 79 & $\begin{array}{r}58,52 \\
\end{array}$ & 56 & +1.48 & 135 & 100,00 \\
\hline AMAZÔNIA & 70 & 45.16 & 85 & 54.84 & 155 & 100,00 \\
\hline Rio Solimões & 75 & 50,00 & 75 & 50.00 & 150 & 100,00 \\
\hline Rio Branco & 84 & 57.14 & 63 & 42,86 & 147 & 100,00 \\
\hline Rio Negro & 74 & 49.01 & 77 & 50.99 & 151 & 100,00 \\
\hline Aipins & 74 & 51,75 & 69 & 48.25 & 143 & 100,00 \\
\hline Bravas & 71 & 46,10 & 83 & 53,90 & 154 & 100,00 \\
\hline
\end{tabular}

\begin{tabular}{|c|c|c|c|c|c|c|}
\hline \multirow[t]{2}{*}{ Regiāo/Tipo } & \multicolumn{6}{|c|}{ AFLP } \\
\hline & Monomórficas & $\%$ & Polimórficas & $\%$ & Total & $\%$ \\
\hline Litoral SP & 65 & 55,56 & $\begin{array}{r}52 \\
\end{array}$ & 44.44 & 117 & 100,00 \\
\hline AMAZÓNIA & 42 & 31.58 & 91 & 68.42 & 133 & 100,00 \\
\hline Rio Solimões & 51 & 41,46 & 72 & 58.54 & 123 & 100,00 \\
\hline Rio Branco & 62 & 51,24 & 59 & 48,76 & 121 & 100,00 \\
\hline Rio Negro & 47 & 35.61 & 85 & 64.39 & 132 & 100,00 \\
\hline Aipins & 54 & 43,55 & 70 & 56,45 & 124 & 100,00 \\
\hline Bravas & 43 & 32,82 & 88 & 67,18 & 131 & 100,00 \\
\hline
\end{tabular}

\begin{tabular}{|c|c|c|c|c|c|c|}
\hline \multirow[t]{2}{*}{ Região/Tipo } & \multicolumn{6}{|c|}{ Microssatélites } \\
\hline & Monomórficas & $\%$ & Polimórficas & $\%$ & Total & $\%$ \\
\hline Litoral SP & 5 & 16,13 & 26 & 83,87 & 31 & 100,00 \\
\hline AMAZÔNIA & 1 & 2,04 & 48 & 97,96 & 49 & 100,00 \\
\hline Rio Solimões & 4 & 10,53 & 34 & 89,47 & 38 & 100,00 \\
\hline Rio Branco & 3 & 8,57 & 32 & 91,43 & 35 & 100,00 \\
\hline Rio Negro & 2 & 4.65 & 41 & 95,35 & 43 & 100,00 \\
\hline Aipins & 2 & 6,25 & 30 & 93.75 & 32 & 100,00 \\
\hline Bravas & 1 & 2,08 & 47 & 97,92 & 48 & 100,00 \\
\hline
\end{tabular}


Tabela 7 - Distribuição das bandas polimórficas segundo sua freqüência, por grupo de variedades de mandioca

\begin{tabular}{|c|c|c|c|c|c|c|c|c|}
\hline \multicolumn{9}{|c|}{ Litoral SP } \\
\hline \multirow{2}{*}{$\begin{array}{l}\text { Intervalos } \\
\text { de freqüêneia } \\
\text { das bandas }\end{array}$} & \multicolumn{2}{|c|}{ RAPD } & \multicolumn{2}{|c|}{ AFLP } & \multicolumn{2}{|c|}{ Microssatélites } & \multicolumn{2}{|c|}{ TOTAL } \\
\hline & $\begin{array}{c}\text { Número } \\
\text { de bandas }\end{array}$ & $\%$ & $\begin{array}{c}\text { Númerō } \\
\text { de bandas }\end{array}$ & $\%$ & $\begin{array}{c}\text { Número } \\
\text { de bandas }\end{array}$ & $\%$ & $\begin{array}{c}\text { Número } \\
\text { de bandas }\end{array}$ & $\%$ \\
\hline$>0-0,09$ & 0 & 0,00 & 0 & 0,00 & $\begin{array}{r}0 \\
\end{array}$ & 0,00 & 0 & 0,00 \\
\hline $0,10-0,19$ & 11 & 19.64 & 9 & 17,31 & 2 & 7.69 & 22 & 16,42 \\
\hline $0,20-0,29$ & 9 & 16,07 & 8 & 15.38 & 2 & 7.69 & 19 & 14,18 \\
\hline $0,30-0,39$ & 5 & 8,93 & 4 & 7,69 & 6 & 23.08 & 15 & 11,19 \\
\hline $0,40-0,49$ & 4 & 7,14 & 6 & 11.54 & 1 & 3.85 & 11 & 8,21 \\
\hline $0,50-0,59$ & 5 & 8,93 & 5 & 9.62 & 3 & 11.54 & 13 & 9,70 \\
\hline $0,60-0,69$ & 1 & 1.79 & 4 & 7.69 & 2 & 7.69 & 7 & 5,22 \\
\hline $0,70 \cdot 0,79$ & 8 & 14.29 & 5 & 9.62 & 7 & 26.92 & 20 & 14,93 \\
\hline $0,80-0,89$ & 13 & 23,21 & 11 & 21,15 & 3 & 11.54 & 27 & 20,15 \\
\hline $0,90-0,99$ & 0 & 0,00 & 0 & 0.00 & 0 & 0.00 & 0 & 0,00 \\
\hline TOTAL & 56 & 100,00 & 52 & 100.00 & 26 & 100,00 & 134 & 100,00 \\
\hline
\end{tabular}

\begin{tabular}{|c|c|c|c|c|c|c|c|c|}
\hline \multirow{3}{*}{$\begin{array}{l}\text { Intervalos } \\
\text { de freqüência } \\
\text { das bandas }\end{array}$} & \multicolumn{8}{|c|}{ AMAZÓNIA } \\
\hline & \multicolumn{2}{|l|}{ RAPD } & \multicolumn{2}{|c|}{\begin{tabular}{|l|} 
AFLP \\
\end{tabular}} & \multicolumn{2}{|c|}{ Microssatélites } & \multicolumn{2}{|c|}{ TOTAL } \\
\hline & $\begin{array}{c}\text { Número } \\
\text { de bandas }\end{array}$ & $\%$ & $\begin{array}{c}\text { Número } \\
\text { de bandas }\end{array}$ & $\%$ & $\begin{array}{c}\text { Número } \\
\text { de bandas }\end{array}$ & $\%$ & $\begin{array}{c}\text { Número } \\
\text { de bandas }\end{array}$ & $\%$ \\
\hline$>0-0,09$ & 6 & 7,06 & 11 & 12,09 & 14 & 29.17 & 31 & 13,84 \\
\hline $0,10-0,19$ & 12 & 14.12 & 9 & 9.89 & 3 & 6.25 & 24 & 10,71 \\
\hline $0,20-0,29$ & 11 & 12,94 & 9 & 9,89 & 8 & 16.67 & 28 & 12,50 \\
\hline $0,30-0,39$ & 12 & 14,12 & 8 & 8.79 & 8 & 16.67 & 28 & 12,50 \\
\hline $0,40-0,49$ & 6 & 7.06 & 6 & 6.59 & 5 & 10.42 & 17 & 7,59 \\
\hline $0,50-0,59$ & 0 & 0,00 & 5 & 5.49 & 2 & 4.17 & 7 & 3,13 \\
\hline $0,60-0,69$ & 7 & 8,24 & 9 & 9.89 & 0 & 0,00 & 16 & 7,14 \\
\hline $0,70-0,79$ & 11 & 12.94 & 7 & 7,69 & 2 & 4,17 & 20 & 8,93 \\
\hline $0,80-0,89$ & 12 & 14,12 & 13 & 14,29 & 4 & 8,33 & 29 & 12,95 \\
\hline $0,90-0,99$ & 8 & 9.41 & 14 & 15.38 & 2 & 4.17 & 24 & 10,71 \\
\hline TOTAL & 85 & 100,00 & 91 & 100,00 & 48 & 100,00 & 224 & 100,00 \\
\hline
\end{tabular}

\begin{tabular}{|c|c|c|c|c|c|c|c|c|}
\hline \multirow{3}{*}{$\begin{array}{l}\text { Intervalos } \\
\text { de freqüência } \\
\text { das bandas }\end{array}$} & \multicolumn{8}{|c|}{ Rio Rio Solimões } \\
\hline & \multicolumn{2}{|l|}{ RAPD } & \multicolumn{2}{|c|}{\begin{tabular}{|l|l|} 
AFLP \\
\end{tabular}} & \multicolumn{2}{|c|}{ Microssatélites } & \multicolumn{2}{|c|}{ TOTAL } \\
\hline & $\begin{array}{c}\text { Número } \\
\text { de bandas }\end{array}$ & $\%$ & $\begin{array}{c}\text { Número } \\
\text { de bandas }\end{array}$ & $\%$ & $\begin{array}{c}\text { Número } \\
\text { de bandas }\end{array}$ & $\%$ & $\begin{array}{c}\text { Número } \\
\text { de bandas }\end{array}$ & $\%$ \\
\hline$>0-0,09$ & 5 & 6,67 & 5 & 6,94 & 7 & 20,59 & $\begin{array}{r}17 \\
\end{array}$ & 9,39 \\
\hline $0,10-0,19$ & 7 & 9,33 & 7 & 9,72 & 5 & 14,71 & 19 & 10,50 \\
\hline $0,20-0,29$ & 12 & 16,00 & 7 & 9,72 & 3 & 8.82 & 22 & 12,15 \\
\hline $0,30-0,39$ & 7 & 9,33 & 10 & 13,89 & 5 & 14,71 & 22 & 12,15 \\
\hline $0,40-0,49$ & 9 & 12,00 & 4 & 5.56 & 2 & 5,88 & 15 & 8,29 \\
\hline $0,50-0,59$ & 3 & 4,00 & 9 & 12,50 & 4 & 11,76 & 16 & 8,84 \\
\hline $0,60-0,69$ & 9 & 12,00 & 7 & 9,72 & 4 & 11,76 & 20 & 11,05 \\
\hline $0,70-0,79$ & 11 & 14,67 & 5 & 6,94 & 2 & 5.88 & 18 & 9,94 \\
\hline $0,80-0,89$ & 8 & 10,67 & 15 & 20,83 & 2 & 5.88 & 25 & 13,81 \\
\hline $0,90-0,99$ & 4 & 5,33 & 3 & 4,17 & 0 & 0,00 & 7 & 3,87 \\
\hline TOTAL & 75 & 100,00 & 72 & 100,00 & 34 & 100,00 & 181 & 100,00 \\
\hline
\end{tabular}


Tabela 7 - Distribuição das bandas polimórficas segundo sua freqüência, por grupo de variedades de mandioca (Continuação)

\begin{tabular}{|c|c|c|c|c|c|c|c|c|}
\hline \multicolumn{9}{|c|}{ Rio Branco } \\
\hline \multirow{2}{*}{$\begin{array}{l}\text { Intervalos } \\
\text { de freqüência } \\
\text { das bandas }\end{array}$} & \multicolumn{2}{|l|}{ RAPD } & \multicolumn{2}{|c|}{ AFLP } & \multicolumn{2}{|c|}{ Microssatélites } & \multicolumn{2}{|c|}{ TOTAL } \\
\hline & $\begin{array}{l}\text { Número } \\
\text { de bandas }\end{array}$ & $\%$ & $\begin{array}{l}\text { Número } \\
\text { de bandas }\end{array}$ & $\%$ & $\begin{array}{l}\text { Número } \\
\text { de bandas }\end{array}$ & $\%$ & $\begin{array}{c}\text { Número } \\
\text { de bandas }\end{array}$ & $\%$ \\
\hline$>0-0,09$ & 0 & 0,00 & 0 & 0,00 & 0 & 0,00 & 0 & 0,00 \\
\hline $0,10-0,19$ & 12 & 19,05 & 17 & 28.81 & 7 & 21,88 & 36 & 23,38 \\
\hline $0,20-0,29$ & 0 & 0,00 & 0 & 0,00 & 0 & 0.00 & 0 & 0,00 \\
\hline $0,30-0,39$ & 18 & 28,57 & 7 & 11,86 & 7 & 21,88 & 32 & 20,78 \\
\hline $0,40-0,49$ & 0 & 0,00 & 0 & 0,00 & 0 & 0,00 & 0 & 0,00 \\
\hline $0.50-0.59$ & 10 & 15,87 & 13 & 22,03 & 13 & 40,63 & 36 & 23,38 \\
\hline $0,60-0,69$ & 13 & 20,63 & 7 & 11.86 & 2 & 6,25 & 22 & 14,29 \\
\hline $0,70-0,79$ & 0 & 0,00 & 0 & 0,00 & 0 & 0,00 & 0 & 0,00 \\
\hline $0,80-0,89$ & 10 & 15,87 & 15 & 25,42 & 3 & 9.38 & 28 & 18,18 \\
\hline $0,90-0,99$ & 0 & 0,00 & 0 & 0,00 & 0 & 0,00 & 0 & 0,00 \\
\hline TOTAL & 63 & 100,00 & 59 & 100,00 & 32 & 100,00 & 154 & 100,00 \\
\hline
\end{tabular}

\begin{tabular}{|c|c|c|c|c|c|c|c|c|}
\hline \multicolumn{9}{|c|}{ Rio Negro } \\
\hline \multirow{2}{*}{$\begin{array}{c}\text { Intervalos } \\
\text { de freqüência } \\
\text { das bandas }\end{array}$} & \multicolumn{2}{|l|}{ RAPD } & \multicolumn{2}{|c|}{ AFLP } & \multicolumn{2}{|c|}{ Microssatélites } & \multicolumn{2}{|c|}{ TOTAL } \\
\hline & $\begin{array}{c}\text { Número } \\
\text { de bandas }\end{array}$ & $\%$ & $\begin{array}{c}\text { Número } \\
\text { de bandas }\end{array}$ & $\%$ & $\begin{array}{c}\text { Número } \\
\text { de bandas }\end{array}$ & $\%$ & $\begin{array}{c}\text { Número } \\
\text { de bandas }\end{array}$ & $\%$ \\
\hline$>0-0,09$ & 12 & 15,58 & 12 & 14,12 & 8 & 19.51 & 32 & 15,76 \\
\hline $0,10-0,19$ & 6 & 7.79 & 7 & 8,24 & 6 & 14,63 & 19 & 9,36 \\
\hline $0,20-0,29$ & 4 & 5,19 & 9 & 10.59 & 4 & 9.76 & 17 & 8,37 \\
\hline $0,30-0,39$ & 10 & 12,99 & 10 & 11,76 & 8 & 19,51 & 28 & 13,79 \\
\hline $0,40-0,49$ & 7 & 9,09 & 5 & 5.88 & 4 & 9.76 & 16 & 7,88 \\
\hline $0,50-0,59$ & 6 & 7.79 & 4 & 4.71 & 1 & 2.44 & 11 & 5,42 \\
\hline $0,60-0,69$ & 7 & 9,09 & 1 & 1,18 & 4 & 9.76 & 12 & 5,91 \\
\hline $0,70-0,79$ & 9 & 11,69 & 15 & 17.65 & 2 & 4.88 & 26 & 12,81 \\
\hline $0,80-0,89$ & 7 & 9,09 & 10 & 11.76 & 1 & 2,44 & 18 & 8,87 \\
\hline $0,90-0,99$ & 9 & 11.69 & 12 & 14.12 & 3 & 7.32 & 24 & 11,82 \\
\hline TOTAL & 77 & 100,00 & 85 & 100,00 & 41 & 100,00 & 203 & 1,00 \\
\hline
\end{tabular}


Tabela 7 - Distribuição das bandas polimórficas segundo sua freqüência, por grupo de variedades de mandiocæ (Continuação)

\begin{tabular}{|c|c|c|c|c|c|c|c|c|}
\hline \multicolumn{9}{|c|}{ Aipins } \\
\hline \multirow{2}{*}{$\begin{array}{l}\text { Intervalos } \\
\text { de freqüência } \\
\text { das bandas }\end{array}$} & \multicolumn{2}{|l|}{ RAPD } & \multicolumn{2}{|c|}{ AFLP } & \multicolumn{2}{|c|}{ Microssatélites } & \multicolumn{2}{|c|}{ TOTAL } \\
\hline & $\begin{array}{c}\text { Número } \\
\text { de bandas }\end{array}$ & $\%$ & $\begin{array}{c}\text { Nümero } \\
\text { de bandas }\end{array}$ & $\%$ & $\begin{array}{c}\text { Número } \\
\text { de bandas }\end{array}$ & $\%$ & $\begin{array}{c}\text { Numero } \\
\text { de handas }\end{array}$ & $\%$ \\
\hline$>0-0,09$ & 7 & 10,14 & $\begin{array}{r}7 \\
\end{array}$ & 10,00 & 0 & 0,00 & 14 & 8,28 \\
\hline $0,10-0,19$ & 11 & 15,94 & 12 & 17,14 & 1 & 3.33 & 24 & 14,20 \\
\hline $0,20-0,29$ & 10 & 14.49 & 7 & 10,00 & 5 & 16.67 & 22 & 13,02 \\
\hline $0,30 \cdot 0,39$ & 5 & 7.25 & 2 & 2,86 & 4 & 13,33 & 11 & 6,51 \\
\hline $0,40-0,49$ & 3 & 4,35 & 5 & 7,14 & 1 & 3,33 & 9 & 5,33 \\
\hline $0,50-0,59$ & 3 & 4,35 & 7 & 10,00 & 7 & 23.33 & 17 & 10,06 \\
\hline $0,60-0,69$ & 3 & 4.35 & 6 & 8.57 & 3 & 10.00 & 12 & 7,10 \\
\hline $0,70-0,79$ & 7 & 10,14 & 3 & 4.29 & 31 & 10,00 & 13 & 7,69 \\
\hline $0,80-0,89$ & 9 & 13.04 & 11 & 15,71 & 3 & 10.00 & 23 & 13,61 \\
\hline $0,90-0,99$ & 11 & 15,94 & 10 & 14.29 & 3 & 10.00 & 24 & 14,20 \\
\hline TOTAL & 69 & 100,00 & 70 & 100,00 & 30) & 100,00 & 169 & 100,00 \\
\hline
\end{tabular}

\begin{tabular}{|c|c|c|c|c|c|c|c|c|}
\hline \multirow{3}{*}{$\begin{array}{c}\text { Intervalos } \\
\text { de freqüência } \\
\text { das bandas }\end{array}$} & \multicolumn{8}{|c|}{ Mandiocas bravas } \\
\hline & \multicolumn{2}{|l|}{ RAPD } & \multicolumn{2}{|c|}{ AFLP } & \multicolumn{2}{|c|}{ Microssatélites } & \multicolumn{2}{|c|}{ TOTAL } \\
\hline & $\begin{array}{c}\text { Número } \\
\text { de bandas }\end{array}$ & $\%$ & $\begin{array}{c}\text { Número } \\
\text { de bandas }\end{array}$ & $\%$ & $\begin{array}{c}\text { Número } \\
\text { de bandas }\end{array}$ & $\%$ & $\begin{array}{c}\text { Número } \\
\text { de bandas }\end{array}$ & $\%$ \\
\hline$>0-0,09$ & 6 & 7,23 & 9 & 10,23 & 14 & 29.79 & 29 & 13,30 \\
\hline $0,10-0,19$ & 14 & 16.87 & 10 & 11,36 & 4 & 8.51 & 28 & 12,84 \\
\hline $0,20-0,29$ & 8 & 9.64 & 8 & 9,09 & 12 & 25.53 & 28 & 12,84 \\
\hline $0,30-0,39$ & 11 & 13,25 & 7 & 7.95 & 4 & 8.51 & 22 & 10,09 \\
\hline $0,40-0,49$ & 4 & 4,82 & 6 & 6,82 & 2 & 4.26 & 12 & 5,50 \\
\hline $0,50-0,59$ & 3 & 3,61 & 8 & 9.09 & 1 & 2.13 & 12 & 5,50 \\
\hline $0,60-0,69$ & 4 & 4,82 & 5 & 5,68 & 2 & 4,26 & 11 & 5,05 \\
\hline $0,70-0,79$ & 16 & 19.28 & 9 & 10.23 & 1 & 2.13 & 26 & 11,93 \\
\hline $0,80-0,89$ & 12 & 14,46 & 13 & 14.77 & 5 & 10,64 & 30 & 13,76 \\
\hline $0,90-0,99$ & 5 & 6,02 & 13 & 14.77 & 2 & +26 & 20 & 9,17 \\
\hline TOTAL & 83 & 100,00 & 88 & 100,00 & 47 & 100,00 & 218 & 100,00 \\
\hline
\end{tabular}


porcentagem de bandas com freqüência menor que $30 \%$ é de $65 \%$ e $20 \%$ respectivamente.

Nos Anexos 4 a 6 , estão apresentadas as freqüências de cada banda dentro de cada grupo de variedades de mandioca.

\subsection{Análise dos alelos de microssatélites \\ Distribuição dos alelos de microssatélites}

A Tabela 8 apresenta o número de alelos diferentes de cada microssatélite, por grupo de variedades de mandioca. Observa-se que o número total de alelos por loco varia de 2 a 8 , com uma média geral de 4,5 alelos por loco.

O Anexo 7 contém os genótipos das 55 variedades de mandioca para os 11 locos de microssatélites.

\section{Distribuição das combinações de alelos de microssatélites}

A partir dos 49 alelos existentes nos 11 locos, 216 diferentes combinações de alelos são possiveis. Destas, 93 foram efetivamente encontradas no conjunto das 55 plantas. O número de diferentes combinações de alelos, por loco, variou de 2 a 16, com média de 8,5 .

O Anexo 8 mostra a distribuição destas 93 combinações de alelos nos grupos de plantas.

A Tabela 9 resume a informação sobre número de combinações diferentes por grupo de plantas. Quanto às diferentes regiões de origem, o grupo que contém maior número de combinações distintas é o do Rio Negro, com 63 combinações de alelos, seguido do Rio Solimões, com 53, Rio Branco, com 44 e finalmente Litoral de São Paulo com 32 diferentes combinações de alelos nos 11 locos.

Quanto às mandiocas bravas e aipins, as diferentes combinações de alelos encontradas nos dois grupos são 45 e 83 , respectivamente. 
Tabela 8 - Número de alelos em 11 microssatélites, por grupo de variedades de mandioca

\begin{tabular}{|c|c|c|c|c|c|c|c|c|}
\hline Microssatélite & R. Negro & R. Branco & R. Solimões & AMAZÓNIA & Litoral SP & TOTAL & Aipins & Bravas \\
\hline GA136 & 5 & \begin{tabular}{|r|}
3 \\
\end{tabular} & 5 & 6 & 3 & 6 & 3 & 6 \\
\hline GA126 & 51 & 4 & 6 & 6 & 5 & 6 & 5) & 5 \\
\hline GA012 & 3 & 3 & 3 & 3 & 3 & 3 & 31 & 3 \\
\hline GA131 & 7 & 5 & 5 & 8 & 3 & 8 & 3 & 8 \\
\hline GA134 & 3 & 2 & 2 & 3 & 2 & 3 & 2 & 3 \\
\hline GA013 & 2 & 1 & 1 & 2 & 1 & 2 & 1) & 2 \\
\hline GA140 & 5 & 5 & 5 & 6 & 4 & 6 & 4 & 6 \\
\hline GA021 & 4 & 4 & 2 & 6 & 3 & 6 & 3 & 6 \\
\hline GAGG5 & 3 & 3 & 3 & 3 & 2 & 3 & 3 & 3 \\
\hline GA057 & 4 & 3 & 4 & 4) & 3 & 4 & 3. & 4 \\
\hline GA016 & 2 & 2 & 2 & 2 & 2 & 2 & 2 & 2 \\
\hline Total & 43 & 35 & 38 & 49 & 31 & 49 & 32 & 48 \\
\hline
\end{tabular}

Tabela 9 - Número de combinaçoes de alelos em 11 locos de microssatélites, por grupo de variedades de mandioca

\begin{tabular}{|c|c|c|c|c|c|c|c|c|}
\hline Microssatélite & R. Negro & R. Branco & R. Solimōes & AMAZÔNIA & Litoral SP & TOTAL & Aipins & Bravas \\
\hline GA136 & $\begin{array}{r}9 \\
\end{array}$ & 4 & 8 & 12 & 3 & 12 & 4 & 12 \\
\hline GA126 & 8 & 4 & 6 & 10 & 5 & 12 & 7 & 8 \\
\hline GA012 & 4 & 6 & 5 & 6 & 3 & 6 & 4 & 6 \\
\hline GA131 & 9 & 6 & 10 & 15 & 3 & 15 & 5 & 12 \\
\hline GA134 & 4 & 2 & 2 & 4 & 2 & 4 & 2 & 4 \\
\hline GA013 & 2 & 1 & 1 & 2 & 1 & 2 & 1 & 2 \\
\hline $\mathrm{GAl} 40$ & 8 & 6 & 6 & 15 & 3 & 16 & 5 & 15 \\
\hline GA021 & 5 & 4 & 3 & 7 & 3 & 9 & 4 & 7 \\
\hline GAGG5 & 6 & 4 & 4 & 6 & 2 & 6 & 4 & 6 \\
\hline GA057 & 5 & 5 & 6 & 8 & 4 & 8 & 6 & 8 \\
\hline GA016 & 3 & 2 & 2 & 3 & 3 & 3 & 3 & 3 \\
\hline Total & 63 & 44 & 53 & 88 & 32 & 93 & 45 & 83 \\
\hline
\end{tabular}

Tabela 10 - Frequêencia de heterozigotos em 11 microssatélites, por grupo de variedades de mandioca (em \%)

\begin{tabular}{|l|r|r|r|r|r|r|r|r|}
\hline Microssatélite & R. Negro & R. Branco & R. Solimões & AMAZÓNIA & Litoral SP & TOTAL & \multicolumn{1}{c|}{ Aipins } & Bravas \\
\hline GA136 & 86,96 & 83,33 & 87,50 & 86,67 & 88,89 & $\mathbf{8 7 , 2 7}$ & 94,12 & 84,21 \\
\hline GA126 & 60,87 & 50,00 & 81,25 & 66,67 & 88,89 & $\mathbf{7 0 , 9 1}$ & 94,12 & 60,53 \\
\hline GA012 & 60,87 & 50,00 & 50,00 & 55,56 & 77,78 & $\mathbf{6 0 , 0 0}$ & 82,35 & 50,00 \\
\hline GA131 & 91,30 & 83,33 & 87,50 & 88,89 & 100,00 & $\mathbf{9 0 , 9 1}$ & 88,24 & 92,11 \\
\hline GA134 & 52,17 & 50,00 & 6,25 & 35,56 & 55,56 & $\mathbf{3 8 , 1 8}$ & 58,82 & 28,95 \\
\hline GA013 & 4,35 & 0,00 & 0,00 & 2,22 & 0,00 & $\mathbf{1 , 8 2}$ & 0,00 & 2,63 \\
\hline GA140 & 82,61 & 50,00 & 87,50 & 80,00 & 100,00 & $\mathbf{8 3 , 6 4}$ & 88,24 & 81,58 \\
\hline GA021 & 43,48 & 66,67 & 18,75 & 37,78 & 100,00 & $\mathbf{4 9 , 0 9}$ & 88,24 & 31,58 \\
\hline GAGG5 & 47,83 & 50,00 & 31,25 & 42,22 & 77,78 & $\mathbf{4 7 , 2 7}$ & 70,59 & 36,84 \\
\hline GA057 & 43,48 & 66,67 & 56,25 & 51,11 & 66,67 & $\mathbf{5 4 , 5 5}$ & 76,47 & 44,74 \\
\hline GA016 & 26,09 & 33,33 & 37,50 & 31,11 & 66,67 & $\mathbf{3 6 , 3 6}$ & 64,71 & 23,68 \\
\hline Média & $\mathbf{5 4 , 5 5}$ & $\mathbf{5 3 , 0 3}$ & $\mathbf{4 9 , 4 3}$ & $\mathbf{5 2 , 5 3}$ & $\mathbf{7 4 , 7 5}$ & $\mathbf{5 6 , 3 6}$ & $\mathbf{7 3 , 2 6}$ & $\mathbf{4 8 , 8 0}$ \\
\hline
\end{tabular}




\section{Freqüência de heterozigotos para os 11 locos de microssatélites}

A freqüência de indivíduos heterozigotos, por loco, varia de $2 \%$ para o microssatélite GA013 a 91\% para o microssatélite GA131, com média de $56 \%$, no total de 55 plantas (Tabela 10). Detalhes sobre heterozigosidade estão no Anexo 9.

O grupo de plantas que apresenta maior freqüência de plantas heterozigotas é o do Litoral de São Paulo, com $75 \%$ de média para os 11 locos. Segue o grupo do Rio Negro, com 55\%, do Rio Branco, com 53\% e do Rio Solimões, com $49 \%$. Tomadas em conjunto, as plantas provenientes da Amazônia apresentam freqüência média de individuos heterozigotos de $53 \%$.

Comparando as mandiocas bravas e aipins, encontra-se em média $73 \%$ de plantas heterozigotas entre os aipins e $49 \%$ entre as mandiocas bravas.

Quanto à proporção de locos de microssatélites heterozigotos dentro de cada variedade de mandioca, encontra-se um valor mínimo de $23 \%$ de locos heterozigotos (DG065, DG116, DG122 e DG125) e um máximo de 91\% (DG45, DG61 e DG68). O valor médio é de $56 \%$.

A porcentagem média, de locos heterozigotos por planta, nos diferentes grupos, é: 74\% para o Litoral de São Paulo, 55\% para o Rio Negro, 53\% para o Rio Branco e $49 \%$ para o Rio Solimões. Entre os aipins, a porcentagem média de locos heterozigotos por planta é $73 \%$ e entre as bravas $49 \%$.

\section{Índices de diversidade genética para os locos de microssatélites}

$\mathrm{Na}$ Tabela 11, estão os Índices de Diversidade (ID) calculados para cada loco de microssatélites, para cada grupo e para o total de plantas. Os valores de ID total se distribuem entre $\mathrm{ID}=0,02 \mathrm{e} \mathrm{ID}=0,79$, com média de $\mathrm{ID}=0,55$.

Comparando os índices encontrados para cada região, observa-se valores médios semelhantes, com o grupo do Rio Solimões mostrando um diversidade um pouco menor que os demais grupos. No entanto, tomando os locos separadamente, há uma considerável variação de índices de diversidade entre as regiões. Um exemplo é o loco GA126, com os índices de diversidade $\mathrm{ID}=0,65, \mathrm{ID}=0,42, \mathrm{ID}=0,59, \mathrm{ID}=0,56$ e $\mathrm{ID}=0,77$ para as diferentes regiões. 
Quanto aos índices de diversidade, para os aipins, em média foram um pouco maiores que das mandiocas bravas: $I D=0,51$ e $\mathrm{DD}=0,55$, respectivamente. Mas em três locos, a situação foi inversa.

Foram feitas estimativas da distribuição da diversidade entre e dentro dos grupos através dos coeficientes de diferenciação genética $\left(\mathrm{G}_{\mathrm{ST}}\right)$. Os resultados destes cálculos estão nas Tabelas 12 e 13 . Os valores de $\mathrm{H}_{\mathrm{T}}$ são os mesmos apresentados com a denominação de índices de diversidade (ID), na Tabela 11 (vide metodologia no capitulo 3 , item 3.2.5).

A maior parte da diversidade genética está concentrada dentro dos grupos. No agrupamento por região de origem o valor médio de $\mathrm{G}_{S \mathrm{ST}}=0,07$ enquanto que no agrupamento por tipo o valor não passa de $\mathrm{G}_{\mathrm{ST}}=0,04$.

\subsection{Análise dos índices de similaridade entre as 55 variedades de mandioca}

Os índices de similaridade de Nei \& Li, gerados a partir dos três tipos de marcador de DNA para as 55 variedades de mandioca, estão apresentados na forma de matrizes de similaridade nos Anexos 10 a 12.

A Tabela 14 apresenta de forma resumida os valores médios, mínimos e máximos de similaridade, por tipo de marcador. Em função do maior polimorfismo encontrado para os microssatélites, tanto o índice médio de similaridade como a amplitude de variação entre mínimo e máximo refletem uma variabilidade genética maior que a encontrada por meio de RAPD e AFLP.

Para os marcadores de RAPD e AFLP, os índices de similaridade são altos, com média de $S=0,85$ para AFLP e $S=0,89$ para RAPD. A amplitude de variação dos índices de similaridade para RAPD e AFLP não foi muito grande: mínimo de $\mathrm{S}=0,81$ e máximo de $\mathrm{S}=0,89$ e minimo de $\mathrm{S}=0,75$ e máximo de $\mathrm{S}=1,00$, respectivamente. Já para microssatélites, o valor mínimo de similaridade entre duas plantas foi de $\mathrm{S}=0,24 \mathrm{e}$ o máximo foi de $S=1,00$, com média de $S=0,59$.

Calculando os índices de similaridade a partir das 339 bandas dos três marcadores, a maior diversidade revelada pelos microssatélites fica diluida em função do número significativamente menor de bandas disponíveis para este marcador em relação aos ou- 
Tabela 11 - Indices de diversidade (ID), para 11 locos de microssatélite, por grupo de variedades de mandioca

\begin{tabular}{|l|r|r|r|r|r|r|r|r|}
\hline & R. Negro & R. Branco & R. Solimões & Amazônia & Litoral SP & TOTAL & \multicolumn{1}{c|}{ Aipins } & Bravas \\
\hline GA012 & 0,51 & 0,67 & 0,58 & 0,59 & 0,54 & $\mathbf{0 , 5 9}$ & 0,62 & 0,56 \\
\hline GA013 & 0,04 & 0,00 & 0,00 & 0,01 & 0,00 & $\mathbf{0 , 0 2}$ & 0,00 & 0,03 \\
\hline GA016 & 0,23 & 0,44 & 0,30 & 0,33 & 0,49 & $\mathbf{0 , 3 4}$ & 0,47 & 0,25 \\
\hline GA021 & 0,52 & 0,65 & 0,50 & 0,56 & 0,62 & $\mathbf{0 , 6 0}$ & 0,62 & 0,48 \\
\hline GA057 & 0,43 & 0,65 & 0,57 & 0,55 & 0,62 & $\mathbf{0 , 5 8}$ & 0,64 & 0,50 \\
\hline GA126 & 0,65 & 0,42 & 0,59 & 0,56 & 0,77 & $\mathbf{0 , 6 8}$ & 0,76 & 0,59 \\
\hline GA131 & 0,74 & 0,76 & 0,77 & 0,76 & 0,66 & $\mathbf{0 , 7 9}$ & 0,67 & 0,77 \\
\hline GA134 & 0,52 & 0,38 & 0,06 & 0,32 & 0,40 & $\mathbf{0 , 3 8}$ & 0,42 & 0,38 \\
\hline GA136 & 0,74 & 0,63 & 0,69 & 0,69 & 0,54 & $\mathbf{0 , 7 2}$ & 0,61 & 0,74 \\
\hline GA140 & 0,74 & 0,78 & 0,72 & 0,75 & 0,66 & $\mathbf{0 , 7 9}$ & 0,66 & 0,78 \\
\hline GAGG5 & 0,57 & 0,50 & 0,52 & 0,53 & 0,48 & $\mathbf{0 , 5 7}$ & 0,54 & 0,48 \\
\hline Média & $\mathbf{0 , 5 2}$ & $\mathbf{0 , 5 3}$ & $\mathbf{0 , 4 8}$ & $\mathbf{0 , 5 1}$ & $\mathbf{0 , 5 3}$ & $\mathbf{0 , 5 5}$ & $\mathbf{0 , 5 5}$ & $\mathbf{0 , 5 1}$ \\
\hline
\end{tabular}

Tabela 12 - Valores de $\mathrm{G}_{\mathrm{ST}}, \mathrm{H}_{\mathrm{T}}$, e $\mathrm{H}_{\mathrm{S}}$ para 11 locos de microssatélite

Variedades de mandioca agrupadas por região de origem *

\begin{tabular}{|l|r|r|r|}
\hline & \multicolumn{1}{|c|}{$\mathbf{H}_{\mathrm{T}}$} & \multicolumn{1}{|c|}{$\mathbf{H}_{\mathrm{S}}$} & \multicolumn{1}{|c|}{$\mathbf{G}_{\mathrm{ST}}$} \\
\hline GA012 & 0,59 & 0,55 & 0,06 \\
\hline GA013 & 0,02 & 0,02 & 0,00 \\
\hline GA016 & 0,34 & 0,32 & 0,07 \\
\hline GA021 & 0,60 & 0,54 & 0,09 \\
\hline GA057 & 0,58 & 0,53 & 0,08 \\
\hline GA126 & 0,68 & 0,63 & 0,07 \\
\hline GA131 & 0,79 & 0,74 & 0,06 \\
\hline GA134 & 0,38 & 0,35 & 0,09 \\
\hline GA136 & 0,72 & 0,68 & 0,06 \\
\hline GA140 & 0,79 & 0,73 & 0,08 \\
\hline GAGG5 & 0,57 & 0,53 & 0,07 \\
\hline Média & $\mathbf{0 , 5 5}$ & $\mathbf{0 , 5 1}$ & $\mathbf{0 , 0 7}$ \\
\hline
\end{tabular}

Tabela 13 - Valores de $\mathrm{G}_{\mathrm{ST}}, \mathrm{H}_{\mathrm{T}}$, e $\mathrm{H}_{\mathrm{S}}$ para 11 locos de microssatélite Variedades de mandioca agrupadas por tipo *

\begin{tabular}{|l|r|r|r|}
\hline & \multicolumn{1}{|c|}{$\mathrm{H}_{\mathrm{T}}$} & \multicolumn{1}{|c|}{$\mathrm{H}_{\mathrm{S}}$} & \multicolumn{1}{|c|}{$\mathbf{G}_{\mathrm{ST}}$} \\
\hline GA012 & 0,59 & 0,59 & 0,00 \\
\hline GA013 & 0,02 & 0,02 & $-0,01$ \\
\hline GA016 & 0,34 & 0,32 & 0,05 \\
\hline GA021 & 0,60 & 0,53 & 0,11 \\
\hline GA057 & 0,58 & 0,55 & 0,04 \\
\hline GA126 & 0,68 & 0,66 & 0,03 \\
\hline GA131 & 0,79 & 0,75 & 0,04 \\
\hline GA134 & 0,38 & 0,40 & $-0,04$ \\
\hline GA136 & 0,72 & 0,71 & 0,01 \\
\hline GA140 & 0,79 & 0,76 & 0,04 \\
\hline GAGG5 & 0,57 & 0,51 & 0,11 \\
\hline Média & $\mathbf{0 , 5 5}$ & $\mathbf{0 , 5 3}$ & $\mathbf{0 , 0 4}$ \\
\hline
\end{tabular}

$\left.{ }^{*}\right) H_{\mathrm{T}}=$ Diversidade média total

$\mathrm{H}_{\mathrm{S}}=$ Diversidade média nos grupos

$\mathrm{G}_{\mathrm{ST}}=$ Coeficiente de diferenciaçāo genética 
tros dois. $O$ valor médio de similaridade encontrado foi 0,85 , com mínimo de 0,78 e máximo de 0,99 .

\section{Índices de similaridade entre e dentro dos grupos de variedades de mandioca}

Nas Tabelas 15 a 17, estão os índices médios de similaridade entre plantas dentro (na diagonal) e entre regiões, para cada tipo de marcador. Observa-se que há uma tendência, ainda que pequena, da similaridade ser maior entre as plantas de uma mesma região que entre plantas de regiões diferentes.

Essa tendência é mais clara na matriz baseada em dados de microssatélites. Por isso, a Tabela 17 será analisada com mais detalhe. A situação mais contrastante é das plantas provenientes do Litoral de São Paulo: o índice médio de similaridade dentro do grupo é $\mathrm{S}=0,71$, enquanto que entre estas 9 plantas e as plantas do Rio Solimões e do Rio Branco, o índice médio é $\mathrm{S}=0,58$ e em relação às plantas do Rio Negro este índice é de apenas $\mathrm{S}=0,51$.

A situação menos contrastante é das plantas provenientes do Rio Branco. O índice de similaridade médio dentro do grupo de 6 plantas é $\mathrm{S}=0,58$, igual ao índice médio encontrado na comparação destas plantas com as do Rio Solimões, e muito próximo do encontrado na comparação com as plantas do Litoral de São Paulo com $S=0,57.0$ índice é um pouco menor na comparação com as plantas do Rio Negro: $S=0,52$.

Para as variedades do Rio Solimões, o indice médio de similaridade dentro do grupo é $\mathrm{S}=0,61$. Nas comparações com os outros grupos, os valores encontrados são $\mathrm{S}=0,58$ em relação às plantas do Rio Branco e $\mathrm{S}=0,57$ em relação às plantas do Rio Negro e do Litoral de São Paulo.

O grupo do Rio Negro, assim como os outros dois grupos de plantas da Amazônia, também apresenta uma média de similaridade dentro do grupo $(\mathrm{S}=0,62)$ menor que a encontrada no grupo do Litoral de São Paulo. Na comparação entre grupos, os índices médios de similaridade são $\mathrm{S}=0,57, \mathrm{~S}=0,52$ e $\mathrm{S}=0,51$, em relação às plantas do Rio Solimões, Rio Branco e Litoral de São Paulo, respectivamente.

Quanto aos dois tipos, a similaridade também foi maior dentro de grupos do que entre grupos, para os três marcadores (Tabela 18). Assim como no agrupamento 
Tabela 14 - Indices de similaridade de Nei \& Li, entre 55 variedades de mandioca (Média, mínimo e máximo, por tipo de marcador: RAPD, AFLP e microssatélites)

\begin{tabular}{|l|r|r|r|r|}
\hline & \multicolumn{1}{|c|}{ RAPD } & \multicolumn{1}{|c|}{ AFLP } & Microssatélites & \multicolumn{1}{c|}{ TODOS } \\
\hline Média & 0,89 & 0,85 & 0,59 & 0,85 \\
\hline Mínimo & 0,81 & 0,75 & 0,24 & 0.78 \\
\hline Máximo & 0,99 & 1,00 & 1.00 & 0,99 \\
\hline
\end{tabular}

Tabela 15 - Índices médios de similaridade entre e dentro de regiōes Indice de Nei \& Li, a partir de 156 bandas de RAPD

\begin{tabular}{|l|r|r|r|r|}
\hline & Rio Negro & Rio Branco & Rio Solimöes & Litoral SP \\
\hline Rio Negro & $\mathbf{0 , 8 9}$ & & & \\
\hline Rio Branco & 0,88 & $\mathbf{0 , 8 8}$ & & \\
\hline Rio Solimões & 0.88 & 0.88 & $\mathbf{0 , 8 8}$ & \\
\hline Litoral SP & 0.88 & 0.88 & 0.88 & $\mathbf{0 . 9 2}$ \\
\hline
\end{tabular}

Tabela 16 - Índices médios de similaridade entre e dentro de regiōes Indice de Nei e $\mathrm{Li}$, a partir de 134 bandas de AFLP

\begin{tabular}{|l|r|r|r|r|}
\hline & Rio Negro & Rio Branco & Rio Solimões & Litoral SP \\
\hline Rio Negro & $\mathbf{0 , 8 5}$ & & & \\
\hline Rio Branco & 0,84 & $\mathbf{0 , 8 6}$ & & \\
\hline Rio Solimöes & 0,84 & 0,84 & $\mathbf{0 , 8 5}$ & \\
\hline Litoral SP & 0,82 & 0,86 & 0,83 & \\
\hline
\end{tabular}

Tabela 17 - Índices médios de similaridade entre e dentro de regiōes Indice de Nei $\mathrm{L} i$, a partir de 49 bandas de microssatélites

\begin{tabular}{|l|r|r|r|r|}
\hline & Rio Negro & Rio Branco & Rio Solimões & Litoral SP \\
\hline Rio Negro & $\mathbf{0 , 6 2}$ & & & \\
\hline Rio Branco & 0,52 & $\mathbf{0 . 5 8}$ & & \\
\hline Rio Solimões & 0,57 & 0.58 & 0,61 & \\
\hline Litoral SP & 0,51 & 0,57 & 0,57 & $\mathbf{0 , 7 1}$ \\
\hline
\end{tabular}

Tabela 18 - Índices médios de similaridade entre e dentro dos grupos de variedades de mandioca, por tipo, para três marcadores de DNA

\begin{tabular}{|l|r|r|r|}
\hline Tipo & \multicolumn{1}{|c|}{ RAPD } & \multicolumn{1}{|c|}{ AFLP } & Microssatélites \\
\hline Entre grupos & $\mathbf{0 , 8 7}$ & $\mathbf{0 , 8 3}$ & $\mathbf{0 , 5 3}$ \\
\hline Aipins & 0,91 & 0,88 & 0,68 \\
\hline Bravas & 0,89 & 0,85 & 0,59 \\
\hline
\end{tabular}


por regiões, os índices de similaridade baseados em bandas de microssatélites mostram melhor essa tendência do que os outros marcadores: o valor médio de similaridade dentro do grupo de aipins foi $S=0,68$, e do grupo de mandiocas bravas foi $S=0,59$, enquanto que entre os dois grupos o valor médio de similaridade, baseado em microssatélites, foi de $S=0,53$.

\section{Representação gráfica da similaridade entre grupos de variedades de mandioca}

Usando as Tabelas 15, 16 e 17 como matrizes de similaridade entre grupos, segundo a região de origem das plantas, foram gerados os dendrogramas da Figura 8.

Os dendrogramas baseados em bandas de RAPD e AFLP são semelhantes e indicam maior similaridade entre as variedades do Litoral de São Paulo e Rio Branco, em um ramo, e em outro ramo, uma similaridade menor entre as variedades do Rio Solimões e Rio Negro.

O dendrograma baseado em bandas de microssatélites tem uma arquitetura diferente, com o grupo do Rio Negro isolado em um ramo e os outros três juntos no outro ramo. O grupo do Rio Branco, que estava mais próximo do Litoral de São Paulo, agora aparece mais próximo ao grupo do Rio Solimões.

Um aspecto semelhante dos três dendrogramas é que as variedades de mandioca do Rio Negro são as mais distantes, geneticamente, das variedades do Litoral de São Paulo.

\subsection{Agrupamento das 55 variedades de mandioca por similaridade}

Foram gerados 3 dendrogramas para cada tipo de marcador de DNA utilizado e um dendrograma a partir de uma matriz de similaridade baseada no total de 339 bandas dos três marcadores.

As escalas de similaridade são diferentes para cada dendrograma, de modo a otimizar a resolução de cada um deles (Figuras 9 a 12).

Os três dendrogramas elaborados a partir de um só tipo de marcador têm topografias diferentes. No entanto, um aspecto é comum aos três: a existência de um ramo em que estão contidas todas as variedades do Litoral de São Paulo (que também são aipins), 
Figura 8A - Dendrograma com grupos de variedades de mandioca, por região de origem. A partir de 156 bandas de RAPD

(Distância $=1$ - índice de similaridade)

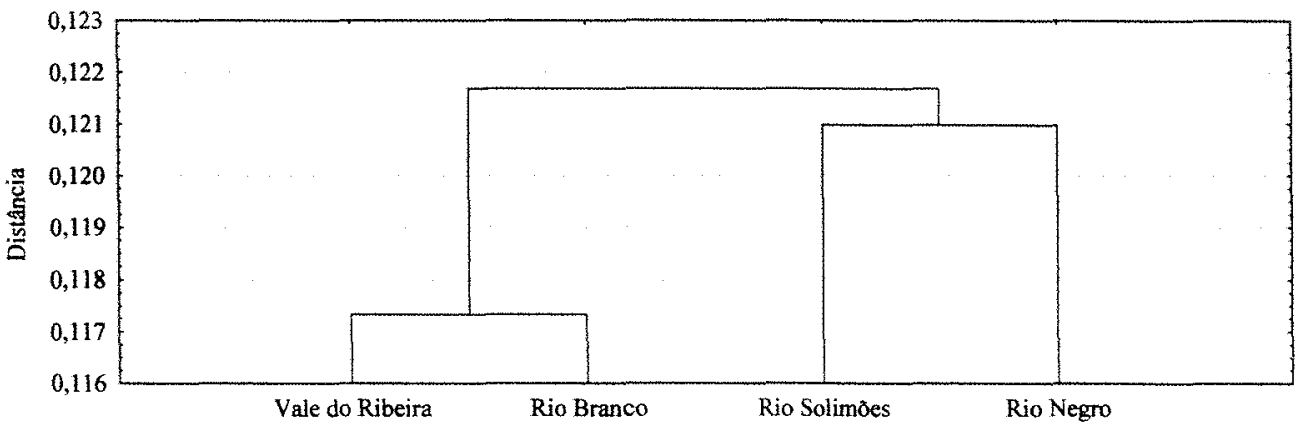

Figura 8B - Dendrograma com grupos de variedades de mandioca, por regioes de origem. A partir de 134 bandas de AFLP

(Distância $=1$ - indice de similaridade de Nei \& Li)

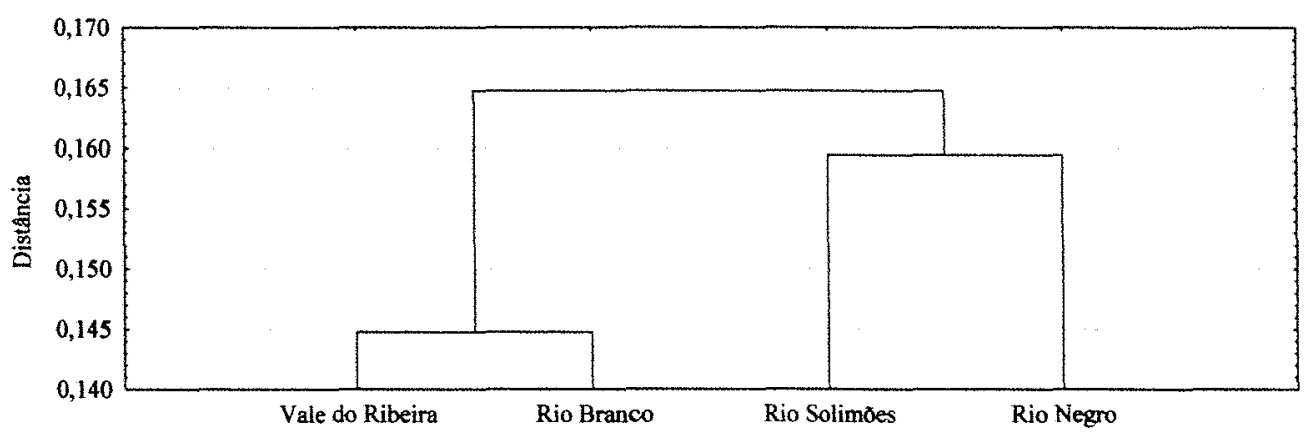

Figura 8C - Dendrograma com grupos de variedades de mantioca, por região de origem. A partir de 49 bandas de microssatélites

(Distância $=1$ - indice de similaridade de Nei \& Li)

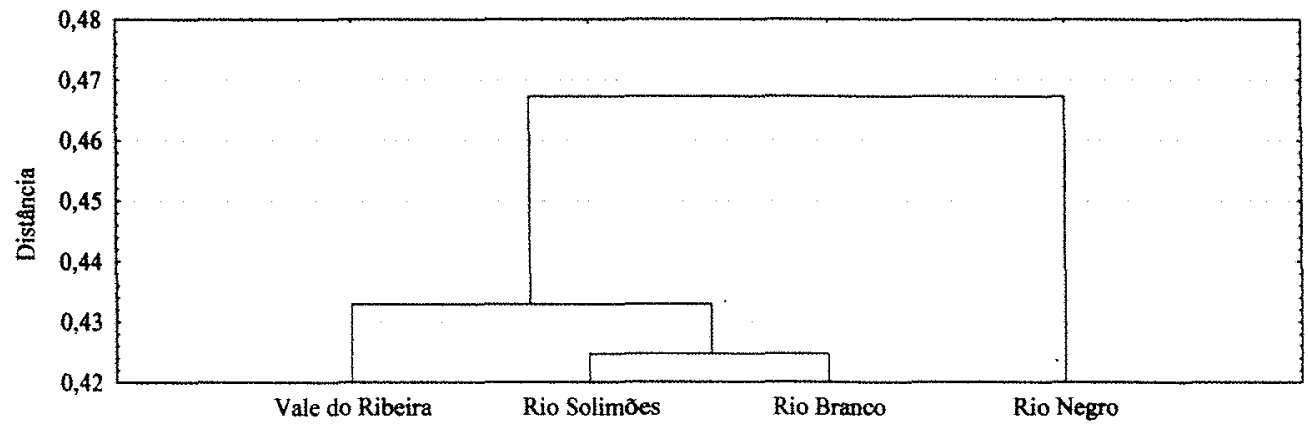


a variedade comercial Mantiqueira, todas as Macaxeiras da Amazônia e mais as variedades DG67 e DG117. Além destas 19 variedades, a DG 65 também está presente neste ramo, muito próxima à Mantiqueira, nos dendrogramas baseados em microssatélites e AFLP. Sobre a DG 117, que é quase idêntica, geneticamente, à DG 118, não há informação sobre o tipo: macaxeira ou brava. Pode ser um caso de erro por troca de material na coleção de germoplasma.

Este ramo, nos dendrogramas baseados em microssatélites, AFLP e no total de bandas, é dividido em dois sub-ramos. Estes sub-ramos incluem variedades diferentes em cada caso.

Não há outros agrupamentos comuns aos três dendrogramas. Os dendrogramas baseados em RAPD e AFLP não têm agrupamentos muito claros, refletindo os altos índices de similaridade entre as variedades que se obtém usando estes marcadores.

A similaridade particularmente acentuada entre algumas plantas se reflete em sua vizinhança nos três dendrogramas: é o caso das variedades DG 38 e DG 112, DG40 e DG 41, DG 138 e DG 120, DG 117 e DG 118, DG 128 e DG 131, DG 49 e DG 59, DG 130 e DG 132, DG 58 e DG 52, DG 43 e DG 51. Outras duplas de variedades muito similares em relação a um tipo de marcador não estão apresentadas juntas em outros dendrogramas, como é o caso das variedades DG 68 e DG 61 e as variedades DG 137 (Mantiqueira) e DG 65, que aparecem juntas dos dendrogramas feitos a partir de AFLP e microssatélites mas não estão juntas no dendrograma baseado ém RAPD.

No dendrograma baseado em microssatélites, a variedade DG 42 aparece isolada em um ramo próprio. No dendrograma baseado em AFLP, esta variedade está em um sub-ramo isolado de um ramo que engloba outras seis variedades dos grupos Rio Solimões e Rio Branco. No dendrograma baseado em RAPD, a DG 42 está incluída no maior dos ramos, distante das seis variedades de que se aproximava no dendrograma baseado em AFLP.

O dendrograma baseado no total de bandas dos três marcadores não é mais informativo do que os outros. Mantém as mesmas tendências apontadas para os anteriores. 


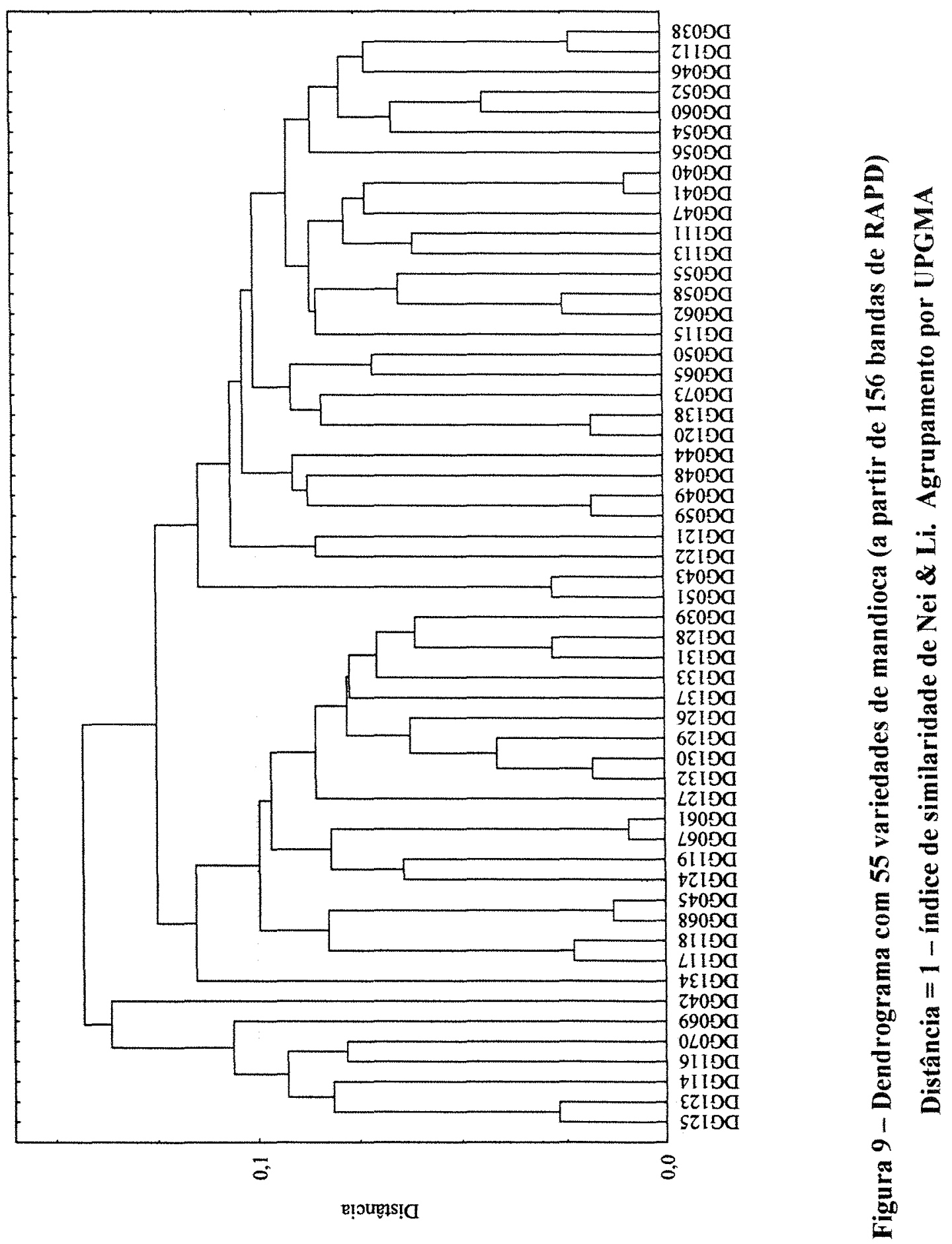



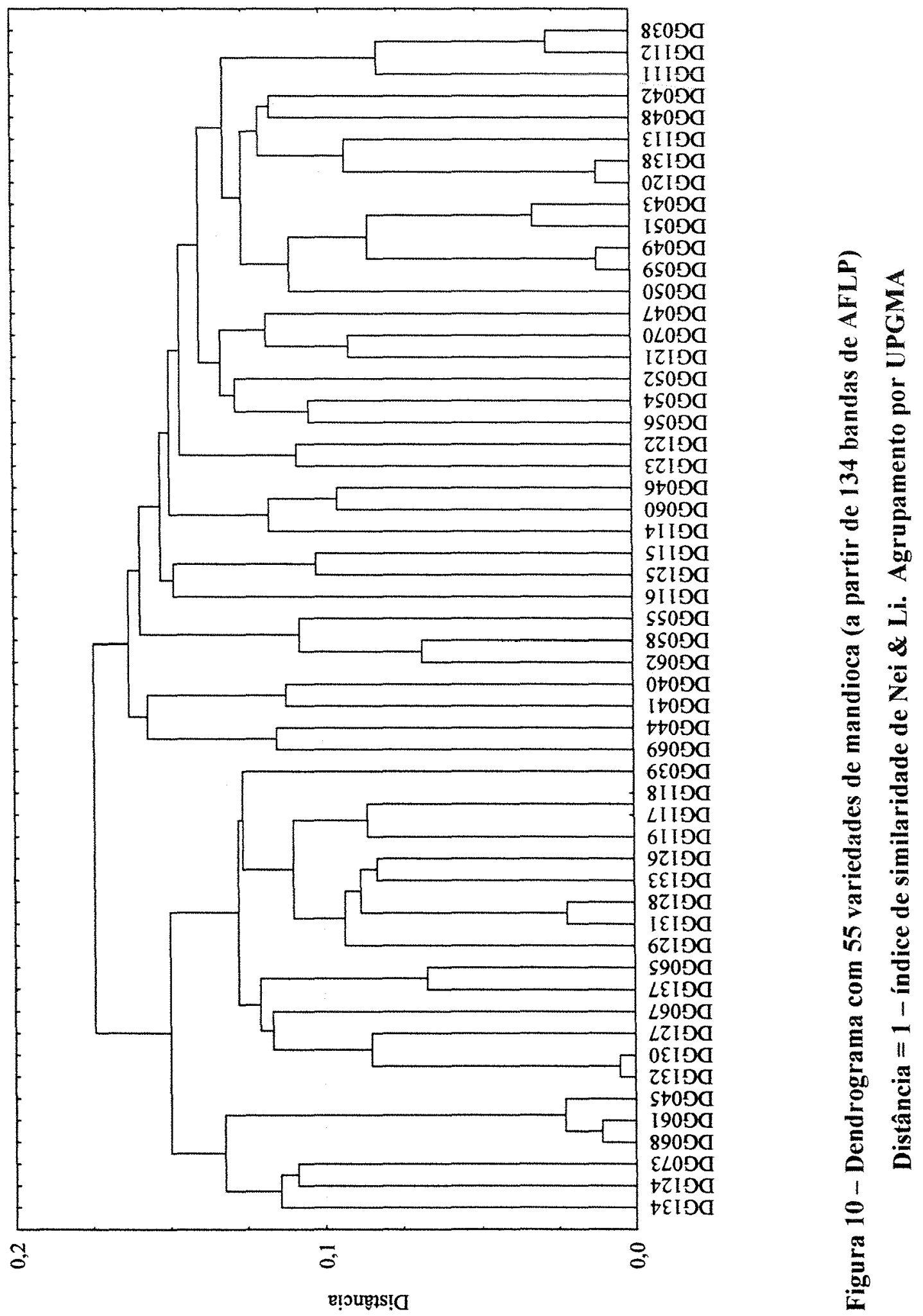


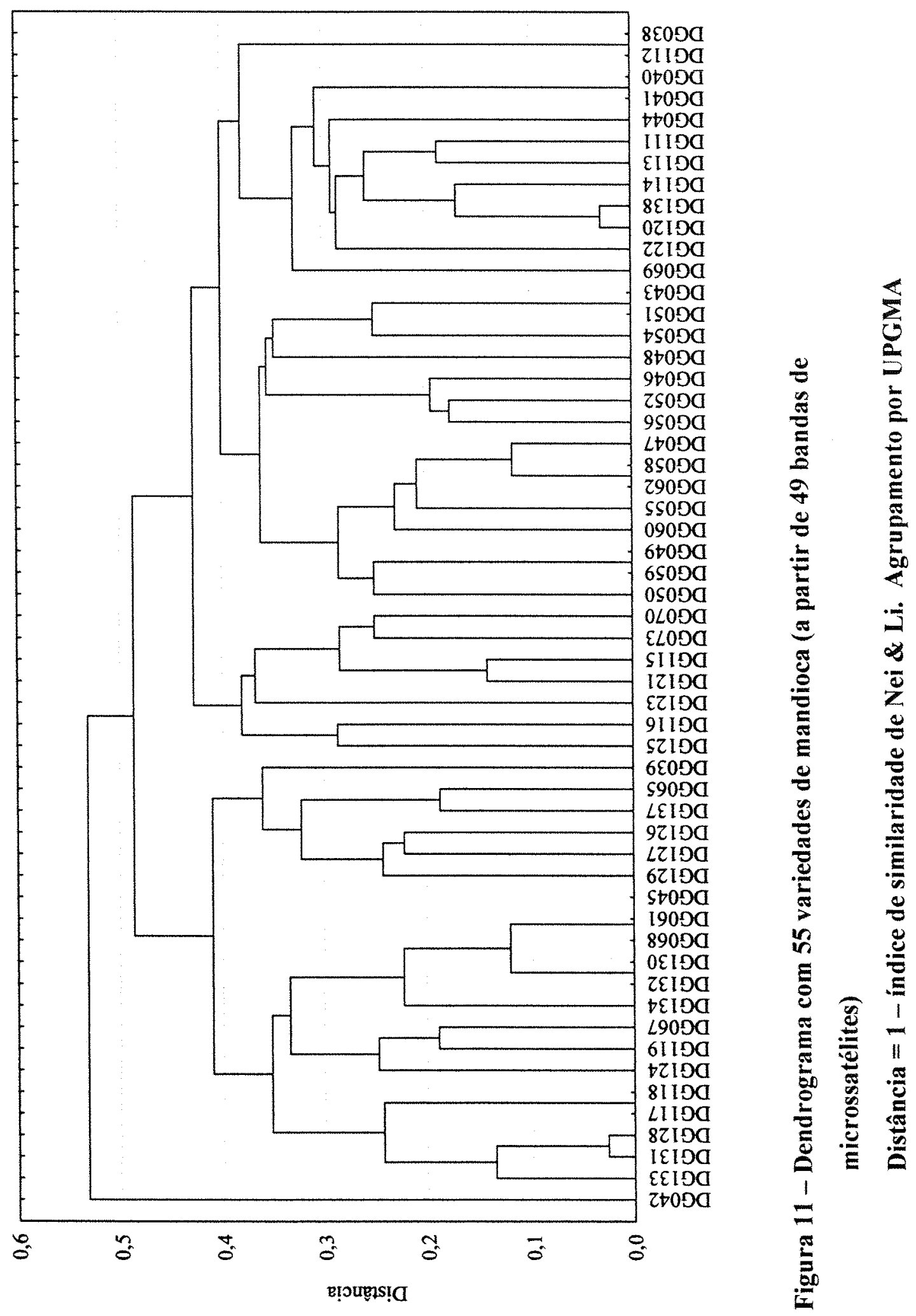




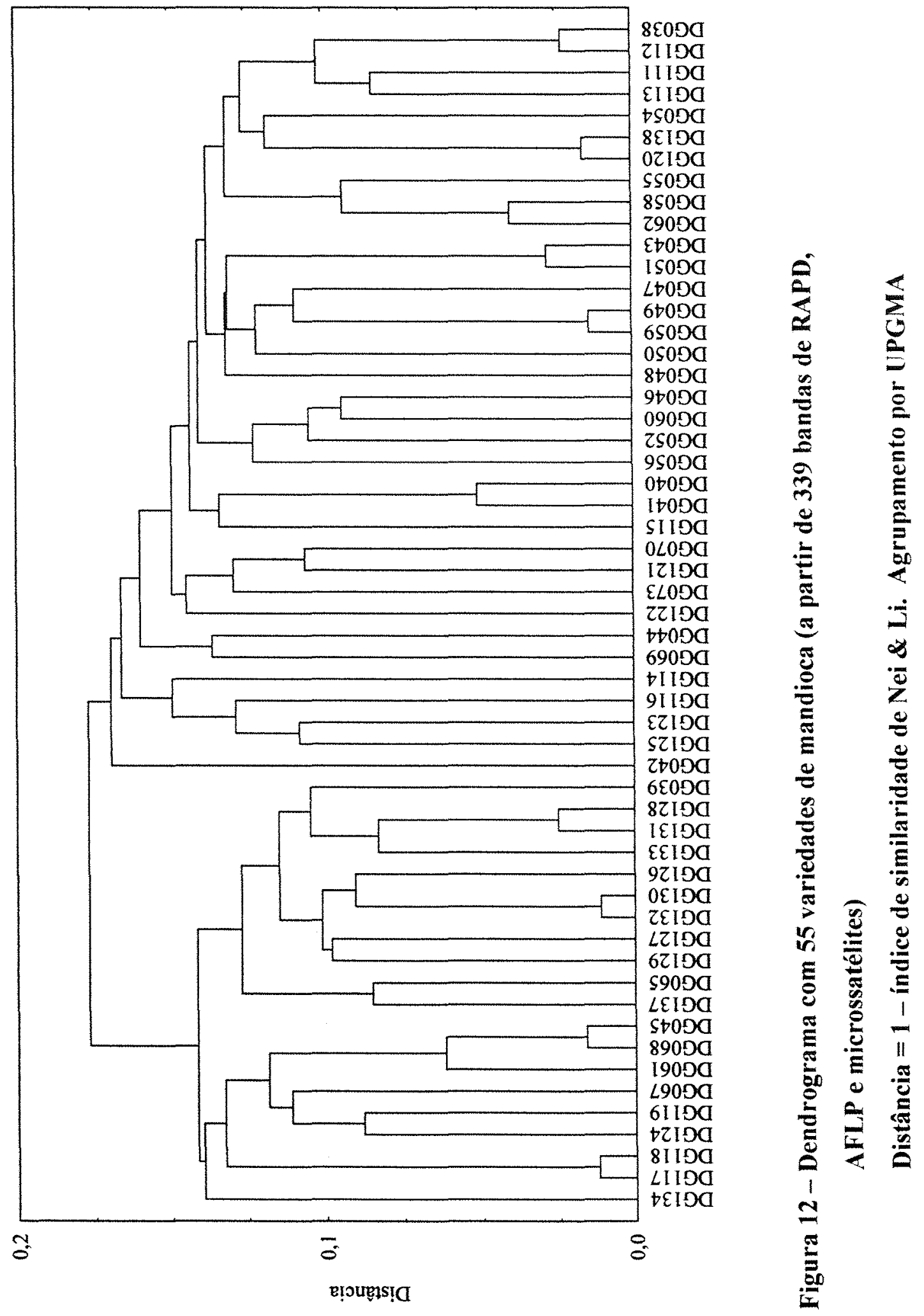


Tabela 19 - Correlações cofenéricas

Para matrizes de similaridade geradas a partir de bandas de 3 tipos de mareador de DNA Índice de similaridade de Nei e Li. Correlaçôes produto-momento (r) *

\begin{tabular}{|l|r|r|r|r|}
\hline & $\boldsymbol{r}$ & $\boldsymbol{Z}$ & \multicolumn{1}{|c|}{$\boldsymbol{t}$} & \multicolumn{1}{|c|}{$\boldsymbol{p}$} \\
\hline RAPD & 0,81283 & $1.157,291$ & 17,214 & 0.001 \\
\hline Microsatélites & 0,73261 & 492,808 & 23,897 & 0.001 \\
\hline AFLP & 0.68586 & $1.055,480$ & 23,887 & 0,001 \\
\hline Todos & 0.83644 & $1.052,049$ & 29,340 & 0.001 \\
\hline
\end{tabular}

Tabela 20 - Correlaçōes entre 4 matrizes de similaridade geradas a partir de três tipos de mareadores de DNA (RAPD, microsatélites e AFLP)

Índice de similaridade de Nei \& Li. Correlaçōes produto-momento (r)

\begin{tabular}{|l|r|r|r|r|}
\hline & \multicolumn{1}{|c|}{ RAPD } & Microsatélites & \multicolumn{1}{c|}{ AFLP } & \multicolumn{1}{c|}{ TODOS } \\
\hline RAPD & 1 & 0.344 & 0.408 & 0.791 \\
\hline Microsatélites & 0.344 & 1 & 0.378 & 0.666 \\
\hline AFLP & 0.408 & 0.378 & 1 & 0.815 \\
\hline TODOS & 0.791 & 0.666 & 0.815 & 1 \\
\hline
\end{tabular}

Tabela 21 - Correlações entre 4 matrizes de similaridade geradas a partir de três tipos de marcadores de DNA (RAPD, microsatélites e AFLP) Índice de similaridade de Nei \& Li. Correlaçōes por ordenação de Spearman

\begin{tabular}{|l|r|r|r|r|}
\hline & \multicolumn{1}{|c|}{ RAPD } & Microsatélites & \multicolumn{1}{|c|}{ AFLP } & \multicolumn{1}{c|}{ TODOS } \\
\hline RAPD & 1 & 0.296 & 0.367 & 0.774 \\
\hline Microsatélites & 0.296 & 1 & 0.310 & 0.606 \\
\hline AFLP & 0.367 & 0.310 & 1 & 0.786 \\
\hline TODOS & 0.774 & 0.606 & 0.786 & 1 \\
\hline
\end{tabular}

Tabela 22 - Correlações entre 4 matrixes de similaridade geradas a partir de AFLP (4 pares de iniciadores)

Indice de similaridade de Nei \& Li. Correlaçōes produto-momento (r) *

\begin{tabular}{|l|r|r|r|r|}
\hline & \multicolumn{1}{|c|}{$\mathbf{r}$} & \multicolumn{1}{|c|}{$\boldsymbol{Z}$} & \multicolumn{1}{c|}{$\boldsymbol{t}$} \\
\hline ACA/CTC - ACA/CAG & 0,189 & $1,048,058$ & 2,843 & 0,002 \\
\hline ACA/CTC - ACT/CAC & 0,246 & 896,691 & 5,412 & 0,001 \\
\hline ACA/CTC - AGG/CAA & 0,292 & $1,013,629$ & 5,886 & 0,001 \\
\hline ACA/CAG - ACT/CAC & 0,089 & $1.032,040$ & 1,630 & 0,057 \\
\hline ACA/CAG - AGG/CAA & $-0,010$ & $1.167,368$ & $-0,165$ & 0,419 \\
\hline ACT/CAC - AGG/CAA & 0,331 & 9998,892 & 7,871 & 0,001 \\
\hline
\end{tabular}

\footnotetext{
$\left(^{*}\right) Z=$ teste estatístico de Mantel

$\mathrm{t}=$ teste $\mathrm{t}$

$p=$ probabilidade de $Z$ aleatónio $<Z$ observado
} 
A Tabela 19 contém as correlações cofenéticas referentes a cada dendrograma. Os valores indicam que há uma fidelidade de fraca a boa nas representações, pelos dendrogramas, das matrizes que os geraram.

As correlações entre matrizes de similaridade, calculadas a partir das tabelas de presença e ausência de bandas de microssatélites, RAPD e AFLP, podem ser vistas na Tabela 20. Os valores de $\mathrm{r}$ (produto-momento) são baixos para as comparações entre as 3 matrizes, mas são significativos. O Anexo 13 mostra os dados completos sobre as correlações.

Um outro cálculo de correlações, não paramétrico (correlações segundo a ordenação, de Spearman), aponta o mesmo resultado (Tabela 21).

As correlações entre as matrizes de similaridade, produzidas independentemente a partir das bandas geradas por cada um dos pares de iniciadores de AFLP, estão na Tabela 22. Observa-se que os valores das correlações são muito baixos mas significativos em quatro das comparações e não são significativos em duas das comparações.

\subsection{Análise de coordenadas principais (PCO)}

Análises de coordenadas principais mostraram que a porção de variabilidade acumulada nos novos eixos, gerados pelas análises, não é grande. Nas Tabelas 23 a 26, estão os autovalores, a porcentagem e a porcentagem acumulada de variância, para os primeiros 10 eixos, obtidos nas análises de coordenadas principais, para cada marcador de DNA. Mesmo com esta limitação, foram elaborados gráficos bidimensionais, plotando os novos "escores", para as variedades de mandioca em função dos dois primeiros eixos definidos nas análises.

Nas Figuras 13A e 13B observa-se a dispersão das 55 variedades de mandioca em função de 156 bandas de RAPD. Na Figura 13A, estão destacadas as regiões de origem das variedades e na Figura 14B, o tipo. Como no dendrograma baseado em RAPD, as plantas do Litoral de São Paulo estão agrupadas e junto com elas todas as Macaxeiras da Amazônia. As únicas mandiocas bravas incluídas neste grupo são a DG117 e a DG 67. 
Tabela 23 - Autovalores dos 10 primeiros eixos gerados em análise de PCO a apartir de matriz de similaridade baseada em 156 bandas de RAPD.

\begin{tabular}{|c|c|c|c|c|c|c|c|c|c|c|}
\hline & Eixo 1 & Eixo 2 & Eixo 3 & Eixo 4 & Eixo 5 & Eixo 6 & Eixo 7 & Eixo 8 & Eixo 9 & Eixo 10 \\
\hline Autovalores & 1,485 & 1,024 & 0,679 & 0.611 & 0.555 & 0,491 & 0.442 & 0,41 & 0.394 & 0,352 \\
\hline$\%$ & 13,143 & 9,067 & 6,01 & 5,408 & 4,91 & 4,348 & 3,91 & 3.629 & 3.486 & 3,113 \\
\hline$\%$ acumulada & 13,143 & 22,21 & 28,221 & 33,629 & 38.539 & 42,887 & 46,797 & 50.426 & 53,912 & 57,025 \\
\hline
\end{tabular}

Tabela 24 - Autovalores dos 10 primeiros eixos gerados em análise de PCO a apartir de matriz de similaridade baseada em 134 bandas de AFLP.

\begin{tabular}{|l|r|r|r|r|r|r|r|r|r|r|}
\hline & Eixo 1 & Eixo 2 & Eixo 3 & Eixo 4 & Eixo 5 & Eixo 6 & Eixo 7 & Eixo 8 & Eixo 9 & Eixo 10 \\
\hline Autovalores & 2.045 & 0.941 & 0.759 & 0.703 & 0.619 & 0,59 & 0.538 & 0.53 & 0.52 & 0,505 \\
\hline$\%$ & 14.01 & 6.45 & 5.201 & 4.816 & 4.238 & 4.045 & 3.684 & 3.628 & 3.561 & 3.463 \\
\hline$\%$ acumulada & 14,01 & 20.46 & 25.661 & 30.477 & 34.714 & 38.759 & 42.443 & 46.07 & 49.632 & 53.095 \\
\hline
\end{tabular}

Tabela 25 - Autovalores dos 10 primeiros eixos gerados em análise de PCO a apartir de matriz de similaridade baseada em 49 bandas de microssatelites.

\begin{tabular}{|l|r|r|r|r|r|r|r|r|r|r|}
\hline & Eixo 1 & Eixo 2 & Eixo 3 & Eixo 4 & Eixo 5 & Eixo 6 & Eixo 7 & Eixo 8 & Eixo 9 & Eixo 10 \\
\hline Autovalores & 4.418 & 2,431 & 2,246 & 1.878 & 1.657 & 1.59 & 1.311 & 1.248 & 1,231 & 1,116 \\
\hline$\%$ & 13,816 & 7,601 & 7,025 & 5,874 & 5.181 & 4.976 & 4,099 & 3.903 & 3.849 & 3.489 \\
\hline$\%$ acumulada & 13,816 & 21,418 & 28,442 & 34,316 & 39,497 & 44,473 & 48,573 & 52.475 & 56.32 .4 & 59,813 \\
\hline
\end{tabular}

Tabela 26 - Autovalores dos 55 eixos gerados em análise de PCO

a apartir de matriz de similaridade baseada em 339 bandas de RAPD, microssatélites e AFLP.

\begin{tabular}{|c|c|c|c|c|c|c|c|c|c|c|}
\hline & Eixo 1 & Eixo 2 & Eixo 3 & Eixo 4 & Eixo 5 & Eixo 6 & Eixo 7 & Eixo 8 & Eixo 9 & Eixo 10 \\
\hline Autovalones & 1,878 & 0,78 & 0,732 & 0,625 & 0.596 & 0,541 & 0,524 & 0,487 & 0.464 & 0,429 \\
\hline$\%$ & 12.751 & 5.296 & 4.969 & 4.244 & 4.045 & 3,67 & 3.557 & 3.304 & 3.15 & 2,91 \\
\hline$\%$ acumulada & 12.751 & 18.047 & 23,016 & 27.26 & 31.305 & 34,975 & 38,532 & 41,836 & 44,986 & 47,896 \\
\hline
\end{tabular}


Figura 13A -Dispersão de 55 variedades de mandioca por similaridade PCoA - A partir de 156 bandas de RAPD

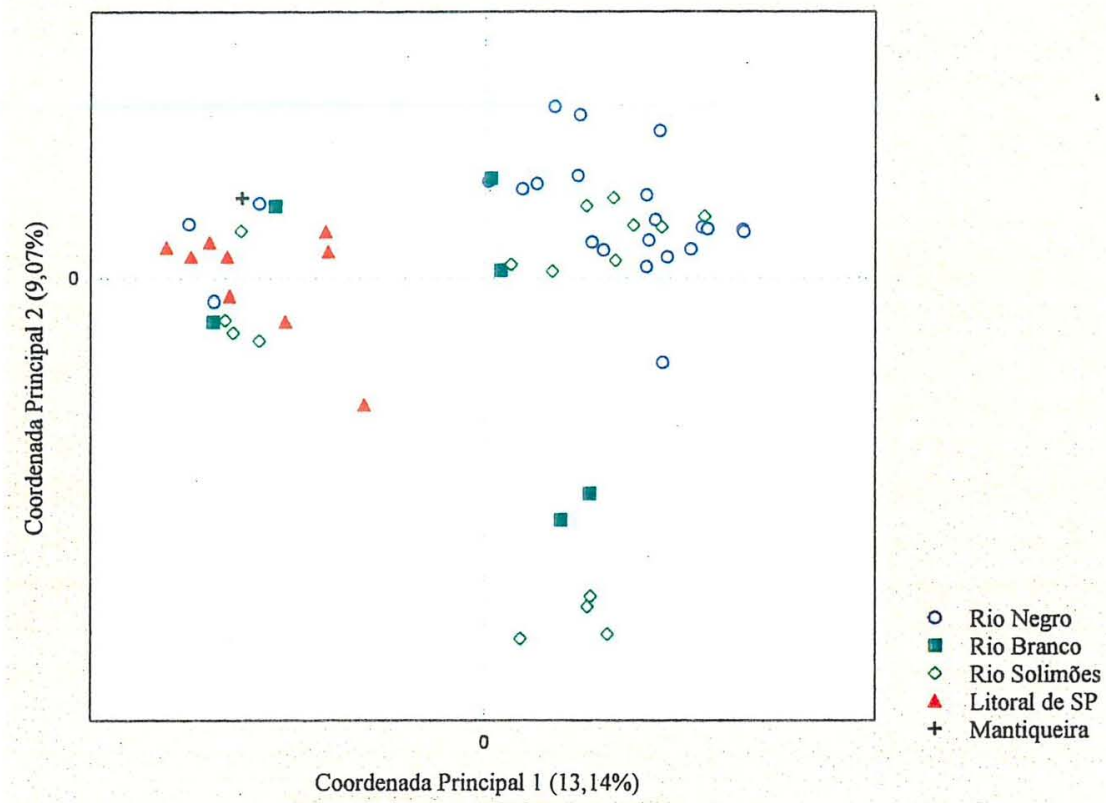

Figura 13B - Dispersão de 55 variedades de mandioca por similaridade PCoA - A partir de 156 bandas de RAPD

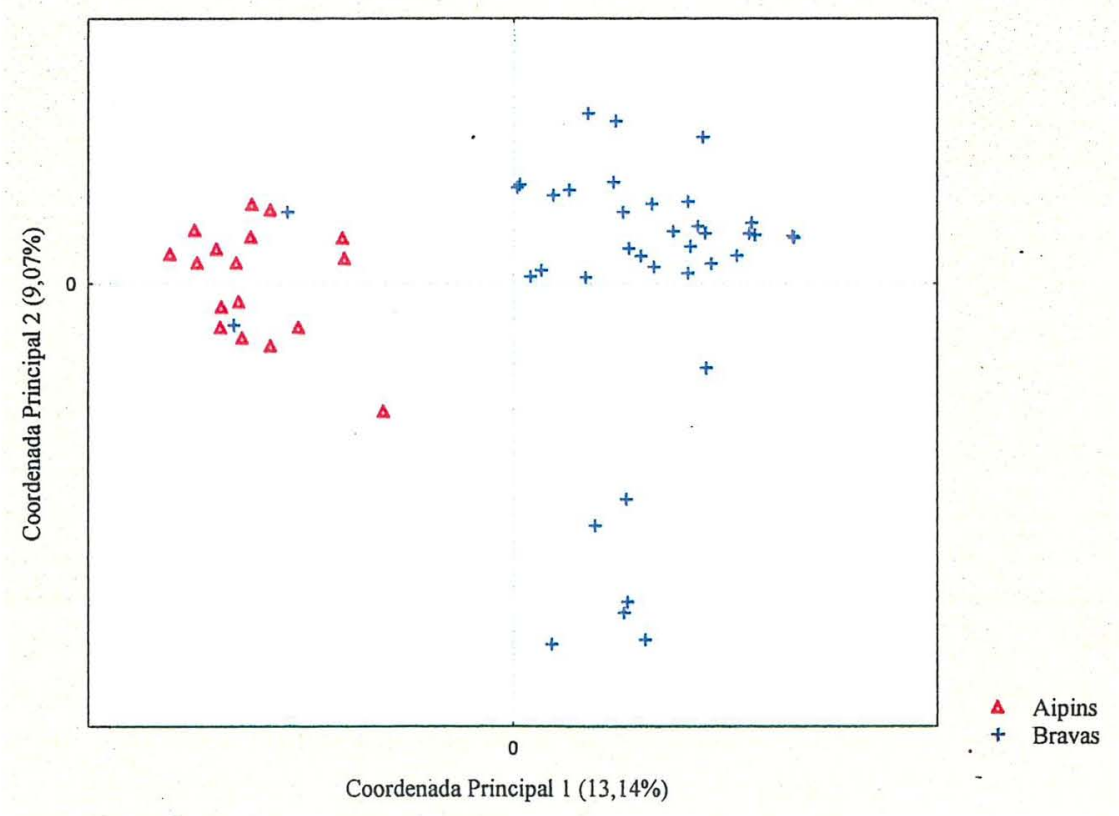


Figura 14A - Dispersão de 55 variedades de mandioca, por similaridade PCoA - A partir de 134 bandas de AFLP

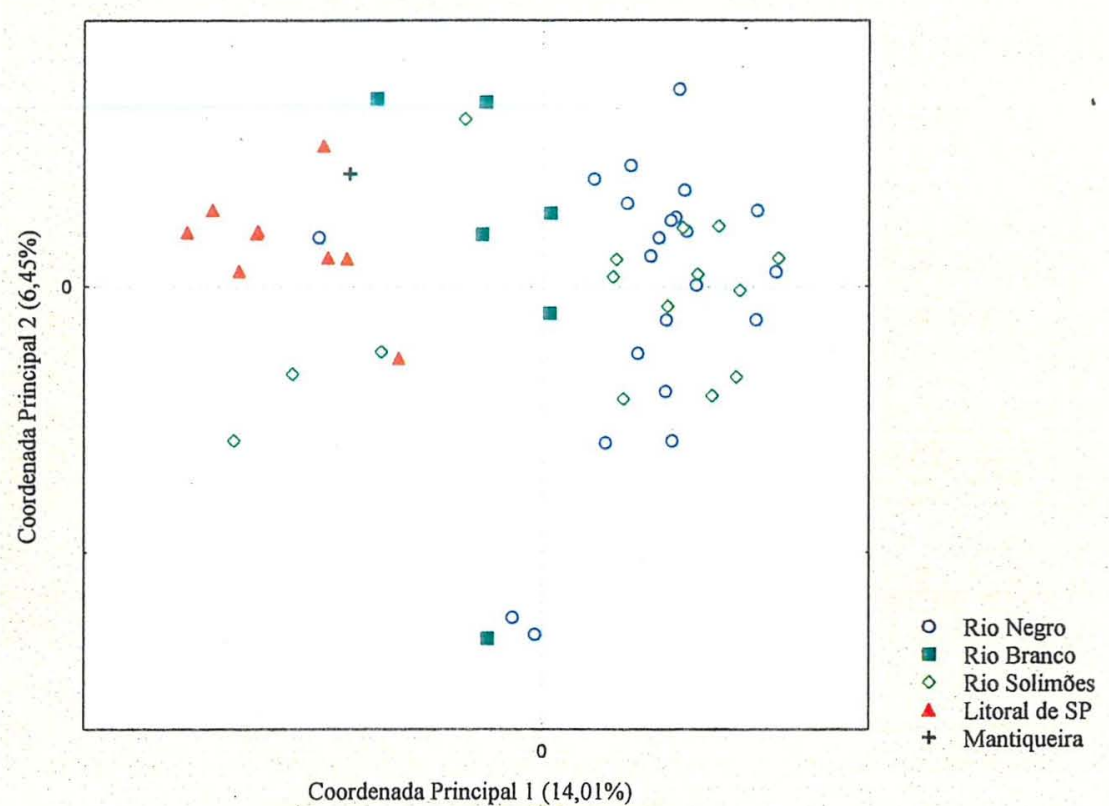

Figura 14B - Dispersão de 55 variedades de mandioca, por similaridade PCoA - A partir de 134 bandas de AFLP

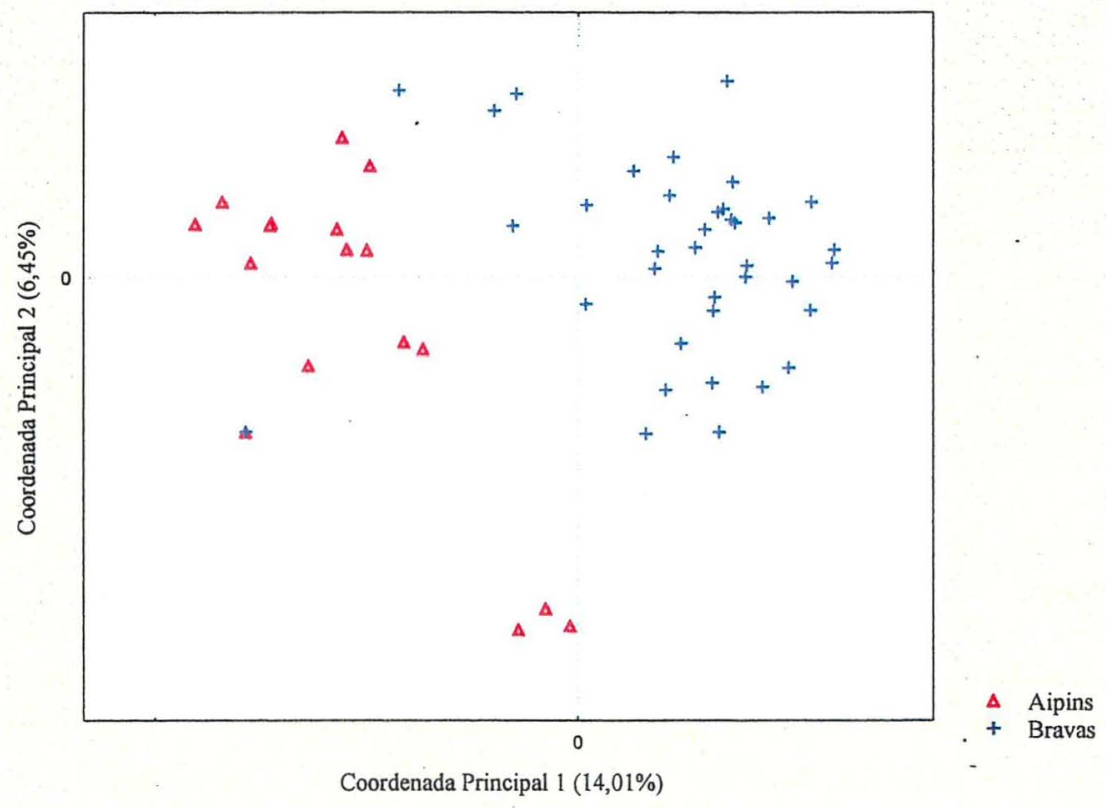


Figura 15A - Dispersão de 55 variedades de mandioca por similaridade PCoA - A partir de 49 bandas de microssatélites

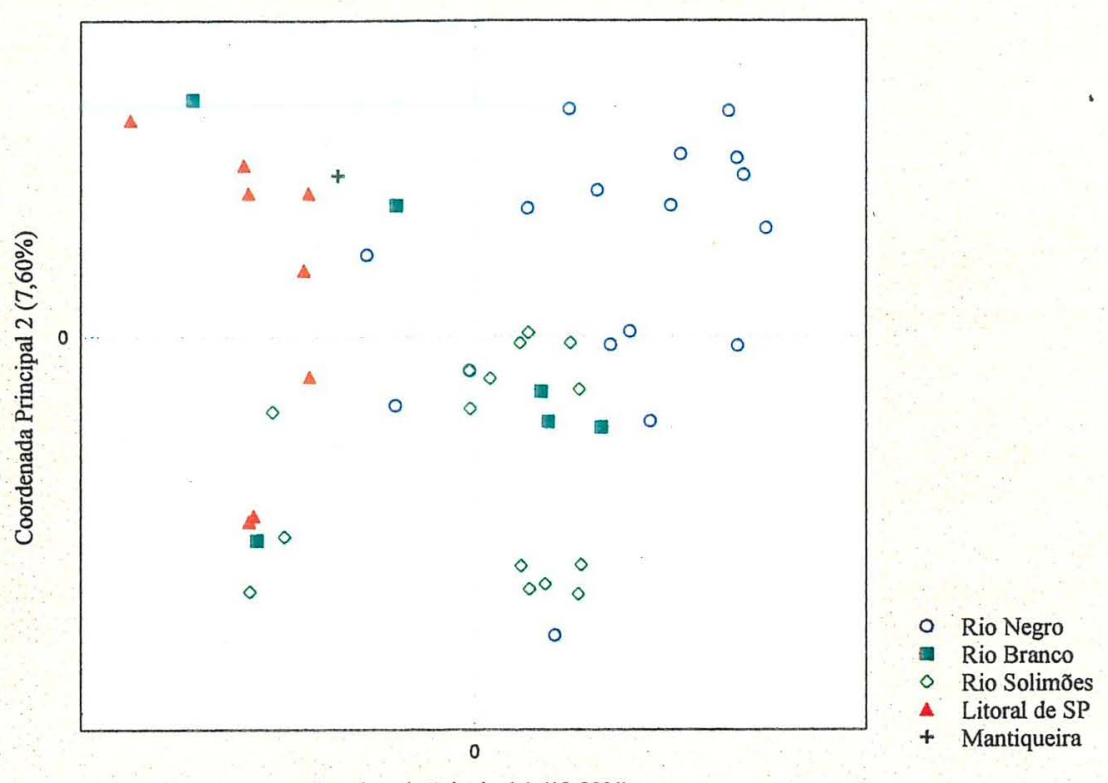

Coordenada Principal $1(13,82 \%)$

Figura 15B - Dispersão de 55 variedades de mandioca, por similaridade PCoA - A partir de 49 bandas de microssatélites

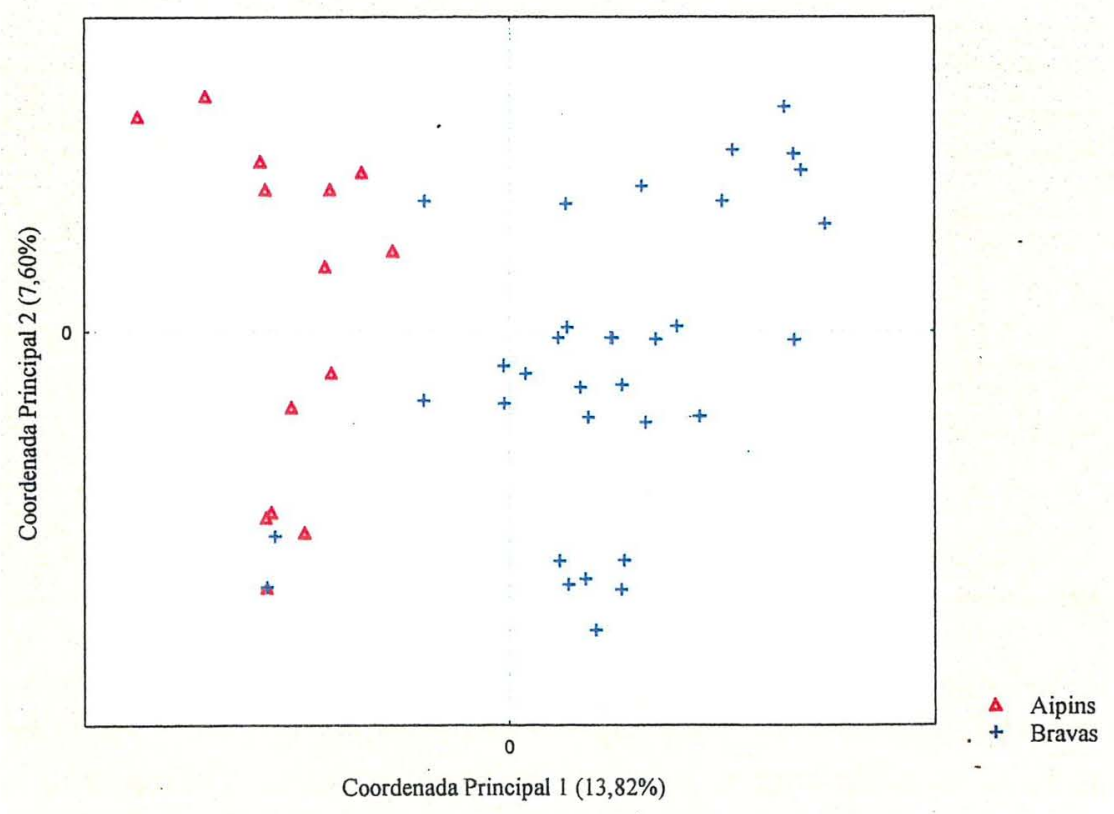


Figura 16A - Dispersão de 55 variedades de mandioca por similaridade PCoA - A partir de 339 bandas de RAPD, AFLP e microssatélites

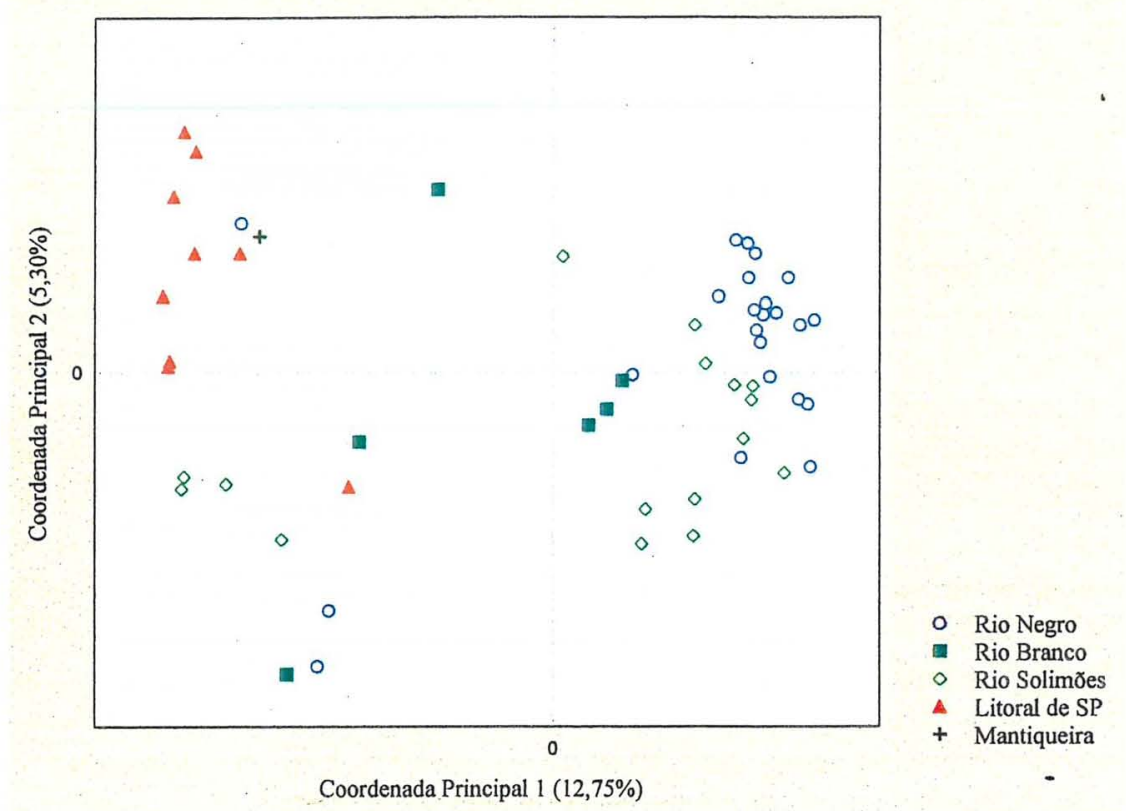

Figura 16B-Dispersão de 55 variedades de mandioca, por similaridade PCOA - A partir de 339 bandas de RAPD, AFLP e microssatélites

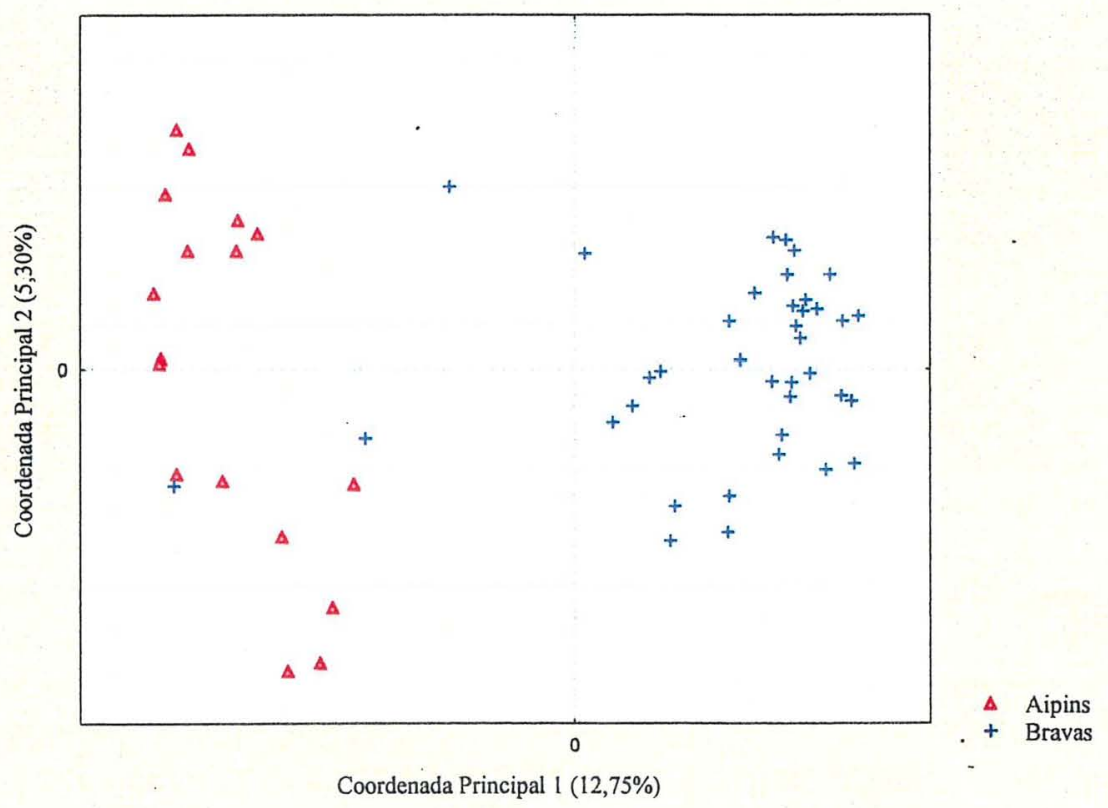


As mandiocas bravas estão divididas em dois grupos, um deles contém todas as plantas do Rio Negro, oito plantas do Rio Solimões e duas do Rio Branco. O outro grupo contém quatro plantas do Rio Solimões e duas do Rio Branco. Não foi possível encontrar nenhuma característica associada a este agrupamento, além da similaridade genética.

Nas Figuras 14A e 14B, é mostrada a dispersão das variedades em função de 134 bandas de AFLP. Aqui também, a divisão entre mandiocas bravas e aipins é visivel mas não tão definida como nos gráficos anteriores. As mandiocas bravas formam um único grupo mas bastante disperso. Os aipins formam dois grupos, um deles com apenas três variedades: DG045, DG061 e DG068. Estas plantas, em relação à coordenada principal 1, estão em posição intermediária entre o grupo de mandiocas bravas e aipins.

Nas Figuras 15A e 15B, com a dispersão baseada nas 49 bandas de microssatélites, apesar de se manterem separadas as mandiocas bravas dos aipins, em função da coordenada principal 1, os dois grupos estão bastante dispersos. Entre as mandiocas bravas, é possivel ver três agrupamentos: um, localizado na parte superior dos gráficos, inclui apenas variedades do Rio Negro; o segundo, na regiâo central, inclui plantas das três regiões amazônicas; o terceiro, na parte de baixo, contém 5 variedades do Rio Solimões e duas (sobrepostas) do Rio Negro. Não são as mesmas variedades que compõe o pequeno grupo observado nas Figuras 13A e 13B.

Finalmente, as Figuras 16A e 16B mostram a dispersão das variedades de mandioca em função do conjunto de 339 bandas obtidas com os três marcadores de DNA. Mantém-se a divisão entre mandiocas bravas e aipins, as variedades bravas do Rio Negro estão bem agrupadas e as variedades bravas do Rio Branco e Rio Solimões estão mais dispersas. Observa-se que existe uma certa separação dos aipins, em função da coordenada principal 2, concentrando-se as variedades oriundas do Litoral de São Paulo na parte superior dos gráficos e as variedades oriundas da Amazônia na parte inferior.

\subsection{Considerações finais}

\section{Quantidade de diversidade}

Considerando como quantificadores da diversidade genética a proporção de bandas polimórficas, o número de alelos de microssatélites, os próprios índices de diversi- 
dade por loco de microssatélite e os índices de similaridade, a diversidade encontrada para este conjunto de etnovariedades de mandioca pode ser considerada de média a alta, se comparada com outras plantas cultivadas (Link et al., 1995; Vierling \& Nguyen, 1992; Hormaza et al., 1994; Papa et al., 1998).

Em relação a uma amostra de 38 variedades da coleção mundial de mandioca mantida no CIAT, a diversidade, para os locos de microssatélites, é equivalente (Roa et al., no prelo). Em relação a um conjunto de 30 etnovariedades dos índios Macuxi, da Guiana Inglesa, a diversidade para os locos de microssatélites é um pouco inferior (dados não publicados de Marianne Elias - CEFE/CNRS).

\section{Distribuição da diversidade}

A distinção, por meio dos marcadores de DNA, entre aipins e mandiocas bravas, se comprovada, pode ter implicações no entendimento da origem e domesticação destes dois tipos de mandioca. Pode ser uma indicação de vias distintas de domesticação.

A existência de niveis de heterozigosidade significativamente diferentes, para os locos de microssatélites, entre mandiocas bravas e aipins, ou entre variedades da Amazônia e do Litoral Sul do Estado de São Paulo, também é um aspecto a ser explorado. Pode indicar diferenças no história evolutiva dos diferentes grupos.

Como todas as plantas oriundas do Litoral de São Paulo eram aipins, não foi possível distinguir perfeitamente o efeito região do efeito tipo, nos agrupamentos por similaridade. Seria necessário incluir variedades bravas entre as plantas do Litoral de São Paulo para uma comprovação dos resultados encontrados.

\section{Marcadores de DNA e outros marcadores}

Em vista da similaridade dos resultados obtidos com os três tipos de marcador de DNA, decorre que o uso de apenas um tipo de marcador é suficiente para avaliar a diversidade genética de variedades de mandioca, desde que o número de marcas seja adequado. 
A baixa correlação entre matrizes de similaridade geradas pelos diferentes marcadores de DNA, possivelmente se deve a três fatores: em primeiro lugar, a erros, na interpretação dos padrões de bandas de RAPD e AFLP; em segundo lugar, à estrutura genética pouco definida da amostra de plantas analisada. Numa situação como esta, seria necessário utilizar maior número de bandas para obter uma correlação maior entre os resultados obtidos com diferentes marcadores; em terceiro lugar, os diferentes marcadores podem estar amostrando diferentes regiões do genoma, levando a resultados distintos.

O fato de as correlações cofenéticas associadas aos dendrogramas não terem sido altas e o fato das porcentagens de variação acumuladas nos eixos, nas análises de componentes principais, terem sido baixas, alertam para que os resultados sejam tomados como indicativos e exploratórios e não como comprovações dos agrupamentos encontrados.

Os resultados obtidos por Cury (1998), avaliando o mesmo conjunto de variedades de mandioca, com descritores morfológicos, caracteres agronômicos e bioquímicos, não indicaram uma distinção genética entre variedades bravas e aipins (ou macaxeiras), nem agrupamentos por região de origem. Apesar desta diferença, o padrão geral de distribuição da diversidade coincidiu com os resultados obtidos no presente trabalho, no sentido de que a diversidade encontra-se concentrada dentro de grupos; o grupo que apresentou maior diversidade foi o das variedades oriundas do Rio Negro; o grupo que apresentou menor diversidade foi do Litoral de São Paulo;

A comparação detalhada dos resultados obtidos com marcadores de DNA e os obtidos com marcadores isoenzimáticos, descritores morfológicos, caracteres agronômicos e bioquímicos, para este mesmo grupo de variedades de mandioca, será apresentada em publicação conjunta com os autores das outras análises. 


\section{CONCLUSÕES}

Marcadores de DNA do tipo RAPD, AFLP e microssatélites, são ferramentas úteis na avaliação de diversidade genética de etnovariedades de mandioca.

A variabilidade dos locos de microssatélites é bastante superior à detectada por RAPD ou AFLP.

Os resultados obtidos com os três marcadores, quanto à distribuição da diversidade genética entre as etnovariedades de mandioca, foram similares, no plano geral, mas com variações.

A diversidade genética, do conjunto de variedades de mandioca estudado, está concentrada dentro de grupos.

O grupo de variedades de mandioca proveniente da região do Rio Negro foi o que apresentou maior diversidade genética.

O grupo de variedades de mandioca proveniente do Rio Branco apresentou uma expressiva amplitude de variação genética, apesar de contar com pequeno número de variedades.

O grupo de variedades de mandioca proveniente do Litoral Sul do Estado de São Paulo foi o que apresentou menor variabilidade genética, mas, ainda assim, bastante significativa.

A possível existência de uma compartimentalização do germoplasma de mandioca entre variedades bravas e aipins (ou macaxeiras), deve ser levada em consideração, no planejamento e interpretação de estudos de diversidade genética da mandioca. 


\section{REFERÊNCIAS BIBLIOGRÁFICAS}

ADAMS, R.P.; RIESEBERG, L.H. The effects of non-homology in RAPD bands on similarity and multivariate statistical ordination in Brassica and Heliantus. Theoretical and Applied Genetics, v. 97, p. 323-326, 1998.

AGRAMA, H.A.; TAREK, C.G.; HOUSSIN, S.F. Genetic linkage maps in maize based on RAPD and RFLP markers. Journal of Genetics and Breeding, v. 51, n. 3, p. 225-233, 1997.

AJMONE MARSAN, P.; CASTIGLIONI, P.; FUSARI, F.; KUIPER, M.; MOTTO, M. Genetic diversity and its relationship to hybrid performance in maize as revealed by RFLP and AFLP markers. Theoretical and Applied Genetics, v. 96, p. 219-227, 1998.

AKAGI, H.; YOKOZEKI, Y.; INAGAKI, A.; FUJIMURA, T. Origin and evolution of twin microsatellites in the genus Oryza. Heredity, v. 81, p. 187-197, 1998.

AL-JANABI, S.M; HONEYCUTT, R.J; McCLELLAND, M.; SOBRAL, B.W.S. A genetic linkage map of Saccharum spontaneum L. 'SES 208'. Genetics, v. 134, p. 1249$1260,1993$.

ALLEM, A.C. Manihot esculenta is native of the neotropics. Plant Genetic Resources News Letter, FAO/IBPGR, v. 71, p. 22-24, 1987.

ALLEM, A.C. A revision of Manihot section Quinquelobae (Euphorbiaceae). Revista Brasileira de Biologia, v. 49, n. 1, p. 1-26, 1989a.

ALLEM, A.C. Four new species of Manihot (Euphorbiacea) from Brazil. Revista Brasileira de Biologia, v. 49, n. 3, p. 649-662, 1989 b.

ALLEM, A.C. Manihot germplasm collecting priorities. In: International network for cassava genetic resources. International Crop Network Series, IPGRI, v. 10, p. 87110, 1994.

ALLEM, A.C. A new species of Manihot (Euphorbiaceae) from the Brazilian Amazon. International Journal of Plant Science, v. 160, n. 1, p. 181-187, 1999. 
ALVAREZ, M.T.; GARCIA, P.; PÉREZ de la VEGA, M. RAPD polymorphism in spanish lentil landraces and cultivars. Journal of Genetics and Breeding, v. 51, p. 9196, 1997.

AVERY, O.T.; MacLEOD, C.M.; McCARTY, M. Studies on the chemical nature of the substance inducing transformation of pneumococcal types. Induction of transformation by a desoxyribonucleic acid fraction isolated from pneumococcus type III. Journal of Experimental Medicine, v. 79, p. 137-158, 1944.

AWOLEYE, F.; DUREN, M. van; DOLEZEL, J.; NOVAK, F.J. Nuclear DNA content and in vitro induced somatic polyploidization in cassava (Manihot esculenta Crantz) breeding. Euphytica, v. 76, p. 195-202, 1994.

BARRENECHE, T.; BODENES, C.; LEXER, C.; TRONTIN, J.F.; FLUCH, S.; STREIFF, R.; PLOMION, C.; ROUSSEL, G.; STEINKELLNER, H.; BURG, K.; FAVRE, J.M.; GLOESSL, J.; KREMER, A. A genetic linkage map of Quercus robur $\mathrm{L}$. (pedunculate oak) based on $\mathrm{RAPD}, \mathrm{SCAR}$, microsatellite, minisatellite, isozyme and 5S rDNA markers. Theoretical and Applied Genetics, v. 97, n. 7, p. 1090-1103, 1998.

BARRETT, B.A.; KIDWELL, K.K. AFLP-based genetic diversity assessment among wheat cultivars from the Pacific Northwest. Crop Science, v. 38, p. 1261-1271, 1998.

BENNETT, M.D.; LEITCH, I.J. Nuclear DNA amouts in Angiosperms. Annals of Botany, v. 76, p. 113-176, 1995.

BOSTER, J. Selection for perceptual distinctiveness: Evidence from Aguaruna cultivars of Manihot esculenta. Economic Botany, v. 49, n. 3, p. 310-325, 1985.

BOSTER, J.S. Classification, cultivation, and selection of Aguaruna cultivars of Manihot esculenta (Euphorbiaceae). Advances in Economic Botany, v. 1, p. 34-47, 1984.

BRUSH, S.B. A farmer-based approach to conserving crop germplasm. Economic Botany, v. 45, n. 2, p. 153-165, 1991.

BRUSH, S.B.; CARNEY, H.J.; HUÁMAN, Z. Dynamics of Andean potato agriculture. Economic Botany, v. 35, p. 70-78, 1981. 
CARVALHO, L.J.C.B.; SCHAAL, B.A.; FUKUDA, W.M.G. Cassava (Manihot esculenta Crantz) phenetic relationships and genetic diversity revealed by morphological descriptors and RAPD markers. Revista Brasileira de Genética, v. 17 (suplemento), p. $13,1998$.

CARVALHO, L.J.C.B.; SCHAAL, B.A.; FUKUDA, W.M.G. Genetic diversity of cassava (Manihot esculenta Crantz) in germplasm collection assessed by RAPD markers. Revista Brasileira de Genética, v. 17 (suplemento), p. 13, 1998.

CARVALHO, L.J.C.B.; SCHAAL, B.A.; FUKUDA, W.M.G. Phenetic relationships and genetic diversity among cassava (Manihot esculenta Crantz) land races revealed by PCR-based markers. Revista Brasileira de Genética, v. 17 (suplemento), p. 14, 1998.

CATTAN-TOUPANCE, L.; MICHALAKIS, Y.; NEEMA, C. Genetic structure of wild bean populations in their South-Andean centre of origin. Theoretical and Applied Genetics, v. 96, p. 844-851, 1998.

CHAKRABORTY, R.; JIN, L. a unified approach to study hypervariable polymorphisms: Statistical considerations of determining relatedness and population distances. In: PENA, S.D.J.; CHAKRABORTY, R.; EPPLEN, J.T.; JEFFREYS, A.J. DNA fingerprinting: State of the science. Basel, 1993. p.153-175.

CHAKRABORTY, R.; KIMMEL, M.; STIVERS, D.N.; DAVISON, L.J.; DEKA, R. Relative mutation rates at di-, tri-, and tetranucleotide microsatellite loci. Proceedings of the National Academy of Sciences from United States of America, v. 94, p. 1041-1046, 1997.

CHALMERS, K.J.; WAUGH, R.; SPRENT, J.I.; SIMONS, A..J.; POWELL, W. Detection of genetic variation between and within populations of Gliricidia sepium and G. maculata using RAPD markers. Heredity, v. 69, p. 465-472, 1992.

CHAVARRIAGA-AGUIRRE, P.; MAYA, M.M.; BONIERBALE, M.V.; KRESOVICH, S.; FREGENE, M.A.; TOHME, J.; KOCHERT, G. Microsatellites in cassava (Manihot esculenta Crantz): discovery, inheritance and variability. Theoretical and Applied Genetics, v. 97, n. 3, p. 493-501, 1998.

CHO, Y.G.; MCCOUCH, S.R.; KUIPER, M.; KANG, M.R.; POT, J.; GROENEN, J.T.M.; EUN,M.Y. Integrated map of AFLP, SSLP and RFLP markers using a 
recombinant inbred population of rice (Oryza sativa L.). Theoretical and Applied Genetics, v. 97, n. 3, p. 370-380, 1998.

CHOWDARI, K.V.; DAVIERWALA, A.P. GUPTA, V.S.; RANJEKAR, P.K.; GOVILA, O.P. Genotype identification and assessment of genetic relationships in pearl millet [Pennisetum glaucum (L.) R. Br] using microsatellites and RAPDs. Theoretical and Applied Genetics, v. 97, p. 154-162, 1998.

CIFARELLI, R.A.; GALLITELLI, M; CELLINI, F. Random amplified hibridization microsatellites (RAHM): isolation of a new class of microsatellite-containing DNA clones. Nucleic Acids Research, v. 23, n. 18, p. 3802-3803, 1995.

CLEVELAND, D.A; SOLERI, D.; SMITH, S.E. Do folk crop varieties have a role in sustainable agriculture? BioScience, v. 44, n. 11, p. 740-751, 1994.

COLOMBO, C. Etude de la diversité génétique de maniocs américains (Manihot esculenta Crantz) par les marqueurs moléculaires (RAPD et AFLP). Montpellier, 1997. 161 p. Thèse (Doctorat) - Ecole Nationale Supérieur Agronomique de Montpellier.

COLOMBO,C.; SECOND, G.; VALLE, T.L.; CHARRIER, A. Genetic diversity characterization of cassava cultivars (Manihot esculenta Crantz). I) RAPD markers. Genetics and Molecular Biology, v. 21, n. 1, p. 105-113, 1998.

COLOMBO, C; , VALLE, T.L. AFLP e RAPD markers for study the genetic diversity of cassava (Manihot esculenta Crantz). Revista Brasileira de Genética, v. 17 (suplemento), p. 14, 1998.

CORREIA, F.A. Ácido cianídrico em algumas variedades de mandioca. Bragantia, v. VII, p. 15-22, 1947.

CRUZ, N.D. Citologia no gênero Manihot Adams. I - Determinação do número de cromossomos em algumas espécies. Anais da Academia Brasileira de Ciências, v. 40, n. 1, p. $91-95,1968$.

CURY, R. Dinâmica evolutiva e caracterização de germoplasma de mandioca (Manihot esculenta, Crantz) na agricultura autóctone. Piracicaba, 1993. 103 p. Dissertação (Mestrado) - Escola Superior de Agricultura "Luiz de Queiroz", Universidade de São Paulo. 
CURY, R. Distribuição da diversidade genética e associação de caracteres em etnovariedades de mandioca (Manihot esculenta, Crantz) provenientes da agricultura tradicional do Brasil. Piracicaba, 1998. 164 p. Tese (Doutorado) - Escola Superior de Agricultura "Luiz de Queiroz", Universidade de São Paulo.

DÁVILA, J.A.; SÁNCHEZ de la HOZ, M.P.; LOARCE, Y.; FERRER, E. The use of random amplified microsatellite polymorphic DNA and coefficients of parentage to determine genetic reationships in barley. Genome, v. 41, p. 477-486, 1998.

DELLAPORTA, S.L.; WOOD, J; HICKS, J.R. A plant DNA minipreparation: version II. Plant Molecular Biology and Reproduction, v. 1, n. 4, p. 19, 1983.

DERMITZAKIS, E.T.; CLARK, A.G.; BATARGIAS, C.; MAGOULAS, A.; ZOUROS, $E$. Negative covariance suggests mutation bias in a two-locus microsatellite system in the fish Sparus aurata. Genetics, v. 150, p. 1567-1575, 1998.

DEVOS, K.M.; GALE, M.D. The use of random amplified polymorphic DNA markers in wheat. Theoretical and Applied Genetics, v. 84, p. 567-572, 1992.

DIRLEWANGER, E.; PRONIER, V.; PARVERY, C.; GUYE, A.; MONET, R. Genetic linkage map of peach (Prunus persica (L.) Batsch) using morphological and molecular markers. Theoretical and Applied Genetics, v.97, n. 5-6, p. 888-895, 1998.

DUFOUR, D.L. Cyanide content of cassava (Manihot esculenta, Euphorbiaceae) cultivars used by Tukanoan indians in northwest Amazonia. Economic Botany, v. 42, p. 255-266, 1988.

DUFOUR, D.L.; WILSON, W.M. La douceur de l'amertume: une ré-évaluation des choix du manioc amer par les indiens Tukano d'Amazonie. In: HLADIK, C.M.; HLADIK, A.; PAGEZY, H.; LINARES, O.F.; KOPPERT, G.J.A.; FROMENT, A. (Eds.) L'alimentation en forêt tropicale. Interactions bioculturelles et perspectives de développement. 1996. Volume 11, chapitre 55, p. 875-896.

ECHT, C.L.S; ERDAHL, L.A.; McCOY, T.J. Genetic segregation of random amplified polymorphic DNA in diploid cultivated alfalfa. Genome, v. 35, p. 84-87, 1992. ECHT, C.S.; MAY-MARQUARDT, P. Survey of microsatellite DNA in pine. Genome, v. 40, p. $9-17,1997$. 
ELIAS, M.; PANAUD, O.; MCKE, D.B.; ROBERT, T. Traditional cultivation of cassava among amerindians: consequences on genetic diversity assessed with AFLP markers. Revista Brasileira de Genética, v. 17 (suplemento), p. 16, 1998.

EMPERAIRE, L.; PINTON, F.; SECOND, G. Gestion dynamique de la diversité variétale du manioc en Amazonie du Nord-Ouest. Natures Sciences Sociétés, v. 6, n. 2, p. 27$42,1998$.

FERGUSON, M.E.; ROBERTSON, L.D.; FORD-LLOYD, B.V.; NEWBURY, H.J.; MAXTED, N. Contrasting genetic variation amongst lentil landraces from different geographical origins. Euphytica, v. 102, p. 265-273, 1998.

FISHER, P.J.; RICHARDSON, T.E.; GARDNER, R.C. Characteristics of single- and multi-copy microsatellites from Pinus radiata. Theoretical and Applied Genetics, v. 96, p. 969-979, 1998.

FLAVELL, R. The molecular characterization and organization of plant chromosomal DNA sequences. Annual Review of Plant Physiology, v. 31, p. 569-596, 1980.

FREGENE, M.; ANGEL, F.; GOMEZ, R.; ROGRIGUEZ, F.; CHAVARRIAGA, P.; ROCA, W.; TOHME, J.; BONIERBALE, M. A molecular genetic map of cassava (Manihot esculenta Crantz). Theoretical and Applied Genetics, v. 95, p. 431-441, 1998.

FREGENE, M.A.; VARGAS, J.; IKEA, J.; ANGEL, F.; TOHME, J.; ASIEDU, R.A.; AKORODA, M.O.; ROCA, W.M. Variability of chloroplast DNA and nuclear ribosomal DNA in cassava (Manihot esculenta Crantz) and its wild relatives. Theoretical and Applied Genetics, v. 89, p. 719-727, 1994.

GOLDBERG, R.B.; HOSCHEK, G.; KAMALAY, J.C. Sequence complexity of nuclear and polysomal RNA in leaves of the tobacco plant. Cell, v. 14, p. 123-131, 1978.

GOODMAN, S.J. $\mathrm{R}_{\mathrm{ST}}$ Calc: a collection of computer programs for calculation estimates of genetic differentiation from microsatellite data and determining their significance. Molecular Ecology, vol. 6, p. 881-885, 1997.

HAMON, P.; TOURE, B. Characterization of traditional yam varieties belonging to the Dioscorea cayenensis-rotundata complex by their isozymic patterns. Euphytica, v. 46, p. 101-107, 1990. 
HARLAN, J.R. The possible role of weed races in the evolution of cultivated plants. Euphytica, v. 14, p. 173-176, 1965.

HARLAN, J.R. Evolutionary dynamics of plant domestication. Japanese Journal of Genetics, v. 41, suppl. 1, p. 337-343, 1969.

HARLAN, J.R. Relationships between weeds and crops. In: Biology and ecology of weeds. Holzner \& Numata (eds), p. 91-96, 1982.

HERSHEY, C.H. Manihot genetic diversity. In: International network for cassava genetic resources. International Crop Network Series, IPGRI, v. 10, p. 111-134, 1994.

HEUN, M.; MURPHY, J.P.; PHILLIPS, T.D. A comparison of RAPD and isozyme analyses for determining the genetic relationships among Avena sterilis L.. accessions. Theoretical and Applied Genetics, v. 87, p. 689-696, 1994

HITE, J.M.; ECKERT, K.A.; CHENG, K.C. Factors affecting fidelity of DNA synthesis during PCR amplification of $d(C-A)_{n}, d(G-T)_{n}$ microsatellite repeats. Nucleic Acids Research, v. 24, n. 12, p. 2429-2434, 1996.

HORMAZA, J.I.; DOLLO, L.; POLITO, V.S. Determination of relatedness and geographical movements of Pistacia vera (Pistachio; Anacardiaceae) germplasm by RAPD analysis. Economic Botany, v. 48, n. 4, p. 349-358, 1994.

KAKES, P. The function of cyanogenesis in cassava. Acta horticulturae, v. 375, p. 79$85,1994$.

KERR, W.E.; CLEMENT, C.R. Práticas agrícolas de conseqüências genéticas que possibilitaram aos indios da Amazônia uma melhor adaptação às condições ecológicas da região. Acta Amazônica, v. 10, n. 2, p. 251-261, 1980.

KIPER, M.; BARTELS, C.; HERZFELD, F.; RICHTER, G. The expression of a plant genome in hnRNA and mRNA. Nucleic Acids Research, v. 6, p. 1961-1978, 1979.

KOSTIA, S.; VARVIO, S.-L.; VAKKARI, P.; PULKKINEN, P. Microsatellite sequences in a conifer, Pinus sylvestris. Genome, v. 38, p. 1244-1248, 1995.

KRUGLYAK, S.; DURRETT, R.T.; SCHUG, M.D.; AQUADRO, C.F. Equilibrium distributions of microsatellite repeat length resulting from a balance between slippage events and point mutations. Proceedings of the National Academy of Sciences from United States of America, v. 95, p. 10774-10778, 1998. 
KRUTOVSKII, K.V.; VOLLMER, S.S; SORENSEN, F.C.; ADAMS, W.T.; KNAPP, S., J.; STRAUS, S.H. RAPD genome maps of Douglas-fir. Journal of Heredity, v. 89 , n. 3, p. 197-205, 1998.

LAGERCRANTZ, U.; ELLEGREN, H.; ANDERSON, L. The abundance of various polymorphic microsatellite motifs differs between plants and vertebrates. Nucleic Acids Research, v. 21, n. 5, p. 1111-1115, 1993.

LANHAM, P.G.; BRENNAN, R.M. Characterization of the genetic resources of redcurrant (Ribes rubrum: subf. Ribesia) using anchored microsatellite markers. Theoretical and Applied Genetics, v. 96, p. 917-921, 1998.

LAUCOU, V.; HAUROGNE, K.; ELLIS, N.; RAMEAU, C. Genetic mapping in pea 1. RAPD-based linkage map of Pisum sativum. Theoretical and Applied Genetics, v. 97, n. 5-6, p. 905-915, 1998.

LEFEVRE, F.; CHARRIER, A. Isozyme diversity within African Manihot germplasm. Euphytica, v. 66, p. 73-80, 1993.

LEFEVRE, F; CHARRIER, A. Heredity of seventeen isozyme loci in cassava (Manihot esculenta Crantz). Euphytica, v. 66, p. 171-178, 1993.

LINK, W.; DIXKENS, C.; SINGH, M.; SCHWALL, M. Genetic diversity in European and Mediterranean faba bean germ plasm revealed by RAPD markers. Theoretical and Applied Genetics, v. 90, p. 27-32, 1995.

LITT, M.; LUTY, A. A hypervariable microsatellite revealed by in vitro amplification of a dinucleotide repeat within the cardiac muscle actin gene. American Journal of Human Genetics, v. 44, p. 397-401, 1989.

LOARCE, Y.; GALLEGO, R.; FERRER, E. A comparative analysis of the genetic relationships between rye cultivars using RFLP and RAPD markers. Euphytica, v. 88 , p. 107-115, 1996.

MAGOON, M.L.; KRISHNAN, R.; BAI, K.V. Morphology of the pachytene chromosomes and meiosis in Manihot esculenta Crantz. Cytologia, v. 34, p. 612626, 1969.

MARILLIA, E.F.; SCOLES, G. The use of RAPD markers in Hordeum phylogeny. Genome, v. 33, p. 635-640, 1996. 
MARTINS, P.S. Biodiversity and agriculture: patterns of domestication of Brazilian native plants. Anais da Academia Brasileira de Ciências, v. 66, suplemento 1, p. 219-223, $1994 \mathrm{a}$.

MARTINS, P.S. Cassava collection. In: MORISHIMA, H.; MARTINS, P.S. Investigations of plant genetic resources in Amazon basin with emphasis on the genus Oryza. Mishima: Monblio International Scientific Research, 1994b. p. 58-62.

McKEY, D.; BECKERMAN, S. Chemical ecology, plant evolution and traditional manioc cultivation systems. In: HLADIK, C.M.; HLADIC, A.; LINARES, O.F.; PAGEZY, H.; SEMPLE, A.; HADLEY, M. (Eds.) Tropical forests, people and food. Biocultural interactions and applications to development. 1993. v. 13, chapter 8 , p. 85-112.

MENDEL, G. Experiments in plant hybridisation. Cambridge: Harvard University Press, 1948. $41 \mathrm{p}$.

MHAMEED, S.; SHARON, D.; KAUFMAN, D.; LAHAV, E.; HILLEL, J.; DEGANI, C.; LEVI, U. Genetic relationships within avocado (Persea americana Mill) cultivars and between Persea species. Theoretical and Applied Genetics, v. 94, p. 279-286, 1997.

MIZUKAMI, Y.; KITO, H.; KUNIMOTO, M.; KOBAYASHI, M. Effect of DNA preparation from laver (Porphyra yezoensis) thalli on reproducibility of RAPD (random amplified polymorphic DNA) patterns. Journal of Applied Phycology, v. 10, n. 1, p. 23-29, 1998.

MKUMBIRA, J.; LAGERCRANTZ, U.; CHIWONA-KARITUN, L.; ROSLING, H.; GULLBERG, U. Genotyping of cassava cultivars in farmers fields in Northern Malawi. Poster in the Fourth International Scientific Meeting of the Cassava Biotechnology Network, Salvador, 1998a.

MKUMBIRA, J.; MAHUNGU, N.M.; SALIPIRA, K.L. Distribution of hydrogen cyanide in cassava germplasm in Malawi. Revista Brasileira de Mandioca, v. 17 (suplemento), p. 75, 1998b.

MORGANTE, M.; OLIVIERI, A.M. PCR-amplified microsatellites as markers in plant genetics. The Plant Journal, v. 3, n. 1, p. 175-182, 1993. 
MOXON, R.; WILLS, C. DNA microsatellites: agents of evolution? Scientific American, p. 72-77, 1999.

NASSAR, N.M.A. Genetic resources of cassava. Chromosome number in Manihot spp. Indian Journal of Genetics and Plant Breeding, v. 38, p. 135-137, 1978.

NAUTA, M.J.; WEISSING, F.J. Constraints on allele size at microsatellite loci: implications for genetic differentiation. Genetics, v. 143, p. 1021-1032, 1996.

NEI, M. Analysis of gene diversity in subdivided populations. Proceedings of the National Academy of Sciences from the United States of America, v. 70, n. 12, p. 3321-3323, 1973.

NEI, M.; LI, W. Mathematical model for studying genetic variation in terms of restriction endonucleases. Proceedings of the National Academy of Sciences from the United States of America, v. 76, p. 5269-5273, 1979.

NORMANHA, E.S. Diferenças entre mandioca mansa e brava. O Agronômico, v. 8, p. $14,1956$.

NYE, M.M. Mis-measure of manioc (Manihot esculenta, Euphorbiaceae). Economic Botany, v. 45, n. 1, p. 47-57, 1991.

OLSEN, K.M.; SCHAAL, B.A. Evidence on the origin of cassava: Phylogeography of Manihot esculenta. Proceedings of the National Academy of Sciences from the United States of America, v. 96, p. 5586-5591, 1999.

OLUFOWOTE, J.L.; XU, Y.; CHEN, X.; PARK, W.D.; BEACHELL, H.M.; DILDAY, R.H.; GOTO, M.; McCOUCH, S.R. Comparative evaluation of within-cultivar variation of rice (Oriza sativa L.) using microsatellite em RFLP markers. Genome, v. 40, p. $370-378,1977$.

PAPA, R.; ATTENE, G.; BARCACCIA, G.; OHGATA, A.; KONISHI, T. Genetic diversity in landrace populations of Hordeum vulgare L. from Sardinia, Italy, as revealed by RAPDs, isozymes and morphophenological traits. Plant Breeding, v. 117, p. 523-530, 1998

PEMBERTON, J.M.; SLATE, J.; BANCROFT, E.R.; BARRETT, J.A. Nonamplifying alleles at microsatellite loci: a caution for parentage and population studies. Molecular Ecology, v. 4, p. 249-252, 1995. 
PEREIRA, A.S.; NERY, J.P.; IGUE, T. Seleção de novos clones de mandioca para mesa, pela toxicidade e paladar de suas raizes "in natura". Bragantia, v. 24, nota $\mathrm{n}$. 10, p. LV-LVIII, 1965.

PEREIRA, A.S.; PINTO, M.G. Determinação da toxicidade da mandioca pelo paladar das raizes "in natura". Bragantia, v. 21, nota n. 25, p. CXLV-CL, 1962.

PERONI, N. Taxonomia folk e diversidade intraespecífica de mandioca (Manihot esculenta (rantz) em roças de agricultura tradicional em áreas de Mata Atlântica do sul do Estado de São Paulo. Piracicaba, 1998. 191 p. Dissertação (Mestrado) Escola Superior de Agricultura "Luiz de Queiroz", Universidade de São Paulo.

PERRY, B.A. Chromosome number and phylogenetic relationship in the Euphorbiaceae. American Journal of Botany, v. 30, p. 527-543, 1943.

PAETKAU, D.; CALVERT, W.; STIRLING, I.; STROBECK, C. Microsatellite analysis of population structure in Canadian polar bears. Molecular Ecology, v. 4, p. 347-354, 1995.

POSEY, D.A. Os Kayapó e a natureza. Ciência Hoje, v. 2, n. 12, p. 35-41, 1984.

POWELL, W.; MORGANTE, M.; ANDRE, C.; McNICOL, J.W.; MACHRAY, G.C.; DOYLE, J.J.; TINGEY, S.V.; RAFALSKI, J.A. Hypervariable microsatellites provide a general source of polymorphic DNA markers for the chloroplast genome. Current Biology, v. 5, n. 9, p. 1023-1029, 1995.

POWELL, W:; MORGANTE, M.; DOYLE, J.J;; McNICOL, TINGEY, S.V.; RAFALSKI, A.J. Genepool varaition in genus Glycine subgenus soja revealed by polymorphic nuclear and chloroplast microsatellites. Genetics, v. 144, p. 793-803, 1996.

PROVAN, J.; POWELL, W.; WAUGH, R. Microsatellite analysis of relationships within cultivated potato (Solanum tuberosum). Theoretical and Applied Genetics, v. 92, p. 1078-1084, 1996.

QUIROS, C.F.; TRUCO, M.J.; HU, J. Sequence comparison of two codominant RAPD markers in Brassica nigra: deletion, substitutions and microsatellites. Plant Cell Reports, v. 15, p. 268-270, 1995. 
RABBANI, M.A.; IWABUCHI, A.; MURAKAMI, Y.; SUZUKI, T.; TAKAYANAGI, K. Genetic diversity in mustard (Brassica juncea L.) germplasm from Pakistan as determined by RAPDs. Euphytica, v. 103, p. 235-242, 1998.

RENVOIZE, B.S. The area of origin of Manihot esculenta as a crop plant - a review of the evidence. Economic Botany, v.26, p. 352-360, 1972.

RICHARDSON, T; CATO, S.; RAMSER, J.; KAHL, G.; WELSING, K. Hybridization of microsatellites to RAPD: a new source of polymorphic markers. Nucleic Acids Research, v. 23, n. 18, p. 3798-3799, 1995.

ROA, A.C. Estimación de la diversidad genética en Manihot spp. mediante morfología y marcadores moleculares. Cali, 1996. 222 p. Tesis (Grado)-Facultad de Ciencias, Universidad del Valle.

ROA, A.C; CHAVARRIAGA-AGUIRRE, P.; DUQUE, M.C.; MAYA, M.M.; IGLESIAS, C.; TOHME, J. Cross-species amplification of cassava (Manihot esculenta Crantz) microsatellites within the genus: allelic polymorphism and degree of relationship. (no prelo)

ROA, A.C.; MAYA, M.M.; DUQUE, M.C; TOHME, J.; ALLEM, A.C.; BONIERBALE, M.W. AFLP analysis of relationships among cassava and other Manihot species. Theoretical and Applied Genetics, v. 95, p. 741-750, 1997.

ROGERS, D.J. Some botanical and ethnological considerations of Manihot esculenta. Economic Botany, v. 19, n. 4, p. 369-377, 1965.

ROGERS, D.J.; APPAN, S.G. Manihot, Manihotoides (Euphorbiaceae). Flora Neotropica. Monografia n. 13. 1973. p.

ROGERS, D.J.; FLEMING, H.S. A monograph of Manihot esculenta Crantz. Economic Botany, v. 27, n. 1, p. 1-114.

ROHLF, F.J. NTSYS-pc: Numerical Taxonomy and Multivariate Analysis System. New York: Applied Biostatistics Inc., 1992. 237 p.

ROSLING, H. Molecular anthropology of cassava cyanogenesis. In: BWS Sobral (ed.) The impact of plant molecular genetics. Boston, 1996 . capitulo 18, p. 315-327. 
RUSSELl, J.; FULlER, J.; YOUNG, G.; THOMAS, B.; TARAMINO, G.; MACAULAY, M.; WAUGH, R.; POWELL, W. Discriminating between barley genotypes using microsatellite markers. Genome, v. 40, p. 442-450, 1997.

SAGHAI MAROOF, M.A.; BIYASHEV, R.M.; YANG, G.P.; ZHANG, Q.; ALLARD, R.W. Extraordinarily polymorphic microsatellite DNA in barley: Species diversity, chromosomal locations, and population dynamics. Proceedings of the National Academy of Sciences of the United States of America, v. 91, p. 5466-5470, 1994.

SALICK, U.; CELLINESE, N.; KNAPP, S. Indigenous diversity of cassava: generation, maintenance, use and loss among the Amuesha, Peruvian upper Amazon. Economic Botany, v. 51, n. 1, p. 6-19, 1997.

SAMADI, S.; ERARD, F.; ESTOUP, A.; JARNE, P. The influence of mutation, selection and reproductive systems on microsatellite variability: a simulation approach. Genetical Research, v. 71, p. 213-222, 1998.

SAMBATTI, J.B.M. Erosão genética e conservação de germoplasma de mandioca na agricultura autóctone em Ubatuba - SP. Piracicaba, 1998. 165 p. Dissertação (Mestrado) - Escola Superior de Agricultura "Luiz de Queiroz", Universidade de São Paulo.

SCHLÖTERRER, C.; TAUTZ, D. Slippage synthesis of simple sequence DNA. Nucleic Acids Research, v. 20, n. 2, p. 211-215, 1992.

SCHMIDT, T,; HESLOP-HARRISON, J.S. The physical and genomic organization of microsatellites in sugar beet. Proceedings of the National Academy of Sciences from the United States of America, v. 93, p. 8761-8765, 1996.

SHARON, D.; CREGAN, P.B.; MHAMEED, S.; KUSHARSKA, M.; HILLEL, J.; LAHAV, E.; LAVI, U. An integrated genetic linkage map of avocado. Theoretical and Applied Genetics, v. 95, n. 5-6, p. 911-921, 1997.

SHRIVER, M.D.; JIN, L.; CHAKRABORTY, R.; BOERWINKLE, E. VNTR allele frequency distributions under the stepwise mutation model: a computer simulation approach. Genetics, v. 134, p. 983-993, 1993.

SILVA JARDIM, J.R. Hibridação interespecifica no gênero Manihot Adams. Viçosa, 1984. 74 p. Dissertação (Mestrado) - Universidade Federal de Viçosa. 
SINHA, S.K.; NAIR, T.V.R. Studies on the variability of cyanogenic glucoside content in cassava tubers. Indian Journal of Agricultural Science, v. 38, n. 6, p. 958-963.

SLATKIN, M. A measure of population subdivision based on microsatellite allele frequencies. Genetics, v. 139, p. 457-462, 1995.

SMITH, G.P. Evolution of repeated DNA sequences by unequal crossover. Science, v. 191, p. 528-535, 1976.

SNEATH, P.H.A.; SOKAL, R.R. Numerical taxonomy. San Francisco, 1973. 573 p.

SPADA, A.; CAPORALI, E.; MARZIANI, G.; PORTALUPPI, P.; RESTIVO, F.M.; TASSI, F.; FALAVIGNA, A. A genetic map of Asparagus officinalis based on integrated RFLP, RAPD and AFLP molecular markers. Theoretical and Applied Genetics. v. 97, n. 7, p. 1083-1089, 1998.

STATSOFT INCO. Statistica for Windows: Computer Program Manual. Tulsa: StatSoft Inco., 1996. p.

STILES, J.I.; LEMME, C.; SONDUR, S.; MORSHIDI, M.B.; MANSHARDT, R. Using randomly amplified polymorphic DNA for evaluating genetic relationships among papaya cultivars. Theoretical and Applied Genetics. v. 85, p. 697-701, 1993.

STRUSS, D.; PLIESKE, J. The use of microsatellite markers for detection of genetic diversity in barley populations. Theoretical and Applied Genetics. v. 97, p. 308315,1998 .

SVITASHEV, S.; BRYNGELSSON, T.; LI, W.; WANG, R.R.-C. Genome-specific repetitive DNA and RAPD markers for genome identification in Elymus and Hordelymus. Genome, v. 41, p. 120-128, 1998.

TAUTZ, D.; RENZ, M. Simple sequences are ubiquitous repetitive components of eukaryotic genomes. Nuclei Acids Research, v. 12, p. 4127-4138, 1984.

TAUTZ, D.; TRICK, M.; DOVER, G.A. Cryptic simplicity in DNA is a major source of genetic variation. Nature, v. 322, p. 652-656, 1986.

THORMANN, C.E.; FERREIRA, M.E.; CAMARGO, L..E.A..; TIVANG, J.G.; OSBORN, T.C. Comparison of RFLP and RAPD markers to estimating genetic relationships within and among cruciferous species. Theoretical and Applied Genetics, v. 88, p. 973-980, 1994. 
TOHME, J;; GONZÁLEZ, D.O.; BEEBE, S.; DUQUE, M.C. AFLP analysis or the genetic structure between and within gene pools of the wild Phaseolus vulgaris core collection. Crop Science, v. , p. , 1996

VALDES, A.M.; SLATKIN, M.; FREIMER, N.B. Allele frequencies at microsatellite loci: the stepwise mutation model revisited. Genetics, v. 133, p. 737-749, 1993

VARSHNEY, R.K.; SHARMA, P.C.; GUPTA, P.K.; BALYAN, H.S.; RAMESH, B; ROY, J.K.; KUMAR, A.; SEN, A. Low level of polymorphism detected by SSR in bread wheat. Plant Breeding, v. 117, p. 182-184, 1998.

VIERLING, R.A.; NGUYEN, H.T. Use of RAPD markers to determine the genetic diversity of diploid, wheat genotypes. Theoretical and Applied Genetics, v. 84, p. 835$838,1992$.

VILLAND, J; SKROCH, P.W.; LAI, T; HANSON, P.; KUO, C.G.; NIENHUIS, J. Genetic Variation among tomato accessions from primary and secondary centers of diversity. Crop Science, v. 38, p. 1339-1347, 1998.

VIRK, P.S.; FORD-LLOYD, B.V.; NEWBURY, J.H. Mapping AFLP markers associated with sub-specific differentiation of Oriza sativa (rice) and an investigation of segregation distortion. Heredity, v. 81, p. 613-620, 1998.

VOS, P.; HOGERS, R.; BLEEKER, M.; Van De LEE, T.; HORNES, M.; FRIJTERS, A.; POT, J.; PELEMAN, J.; KUIPER, M.; ZABEAU, M. AFLP: a new technique for DNA fingerprinting. Nucleic Acids Research, v. 23, p. 4407-4414, 1995.

YANG, G.P.; SAGHAI MAOOF, M.A.; XY, C.G.; ZHANG, Q.; BIYASHEV, R.M. Comparative analysis of microsatellite DNA polymorphism in landraces and cultivars of rice. Molecular and General Genetics, v. 245, p. 187-194, 1994.

WANG, R.R.-C.; ZAHAN, X.-Y. Characterization of genome-specific RAPD markers in perennial Triticeae. Agronomical Abstracts, 1996.

WANG, Z; WDBER, J.L.; ZHONG, G.; TANKSLEY, S.D. Survey of plant short tandem DNA repeats. Theoretical and Applied Genetics, v. 88, p. 1-6, 1994.

WANYERA, N.M.W.; HAHN, S.K.; AKEN'OVA, M.E. Introgression of ceara rubber (Manihot glaziovii Muell-Arg) into cassava (M. esculenta Crantz): a morphological and electrophoretic evidence. In: Root crops for food security in Africa. Proceedings of 
the 5th Triennial Symposium of the International Society for Tropical Root Crops Africa Branch. Ibadan, p. 125-130, 1994.

WEBER, J.L. The informativeness of human (DC-DA)N.(DG-DT)N polymorphisms. Genomics, v. 7, p. 524-539.

WEBER, J.L; MAY, P.E. Abundant class of human DNA polymorphisms which can be typed using polymerase chain reaction. American Journal of Human Genetics, v. 44, p. 388-396, 1989.

WEIR, B.S. Genetic data analysis. Sunderland, 1990.

WELSH, J; McCLELLAND, M. Fingerprinting genomes using PCR with arbitrary primers. Nucleic Acids Research, v. 18, n. 24, p. 7213-7218, 1990.

WIERDL, M.; DOMINSKA, M.; PETES, T.D. Microsatellite instability in yeast: dependence on the length of the microsatellite. Genetics, v. 146, p. 769-779, 1997.

WILLIAMS, J.G.K.; KUBELIK, A..R.; LIVAK, K.J.; RAFALSKI, J.A..; TINGEY, S.V. DNA polymorphisms amplified by arbitrary primers are useful as genetic markers. Nucleic Acids Research, v. 18, n. 24, p. 6531-6535, 1990.

WILLIAMS, J.G.K.; RAFALSKI, J.A.; TINGEY, S.V. Genetic analysis using RAPD markers. Methods in Enzymology, v. 218, p. 706-740, 1993.

ZABEAU, M.; VOS, P. Selective restriction fragment amplification: a general method for DNA fingerprinting. European Patent Application 92402629.7 (publ. n. 0534858 A1), 1993. 
APÊNDICE 


\begin{tabular}{|c|c|c|c|c|c|c|c|c|c|c|c|}
\hline Banda & DG038 & $\begin{array}{l}\text { DG039 } \\
\end{array}$ & DG040 & DG041 & DG042 & DG043 & DG044 & DG045 & DG046 & DG047 & $\begin{array}{l}\text { DG048 } \\
\end{array}$ \\
\hline OPX09-A-01 & 0 & 0 & 0 & of & 1) & 0 & 1 & 1) & 1 & 1 & 0 \\
\hline OPX14-A-01 & 11 & 1 & $0]$ & 1 & 0 & 0 & 1 & 0) & 1 & 0 & 1 \\
\hline OPE01-A-01 & 0 & of & 0 & 0 & 0 & 0) & $1]$ & 0 & 0 & 0 & 0 \\
\hline OPE01-A-02 & 0 & 0 & 0 & 0 & 0 & 1 & 0) & 0 & 0 & 0 & 0 \\
\hline OPE03-A-01 & 0 & 0 & 1 & 11 & 0 & 1) & 1 & 0 & 0 & 0 & 1 \\
\hline OPE03-A-02 & 1 & 0 & 1 & 11 & 1 & 0 & 0 & 1 & 1 & I) & 0 \\
\hline OPE03-A-03 & 요 & 1 & 1 & 1 & 의 & 0 & 1 & 1 & 0 & 1) & 0) \\
\hline OPE05-A-01 & 11 & 1 & $?$ & ?) & 1 & 1 & 11 & 1 & 1 & 1 & 1 \\
\hline OPE05-A-02 & 11 & 1 & 1 & 1) & 1 & 1 & 1 & 1 & 1) & 1 & 1 \\
\hline OPE05-A-03 & 1 & 0 & $?$ & ? & 이 & 0 & 0 & 0 & 0 & 0 & 0 \\
\hline OPE06-A-01 & 0 & 0 & () & 0 & ()] & 0 & 11 & 1 & 0 & 1 & 1 \\
\hline OPE07-A-01 & 0 & 1 & of & of & 0 & 0 & 0 & 1 & of & 의 & 0 \\
\hline OPE07-A-02 & 1 & 0 & 1 & 1 & 1 & 0 & 0 & 0 & 1 & 1 & 1 \\
\hline OPE09-A-01 & 1 & 0 & 0 & 0 & 0 & 0 & 0] & a) & ] & 1 & 0 \\
\hline OPE09-A-02 & 0 & 0] & 0 & 0 & 0) & 0 & 0 & 0 & 0 & 1 & 0 \\
\hline OPE10-A-01 & 0 & 1 & 0 & 1 & ()) & 0 & o] & 1 & 1 & 1 & 0 \\
\hline OPE $10-A-02$ & 0 & 1) & $0 \mid$ & ()) & 이 & 0 & 0 & $1]$ & 0 & 0 & 0 \\
\hline OPE10-A-03 & 1 & 0 & 0 & 0 & 0 & 0 & 0 & 1 & 0 & 0 & 0 \\
\hline OPE10-A-04 & ol & 0 & 1 & 1 & 0 & 1 & 0 & 0 & 1 & 0 & 1 \\
\hline OPE11-A-01 & 7 & 0 & 1 & 11 & 1 & 0 & 1] & 1 & o & 1 & ] \\
\hline OPE11-A-02 & 1) & 1 & 1 & 1 & 11 & 1 & 1 & 0 & 1 & 1 & 1 \\
\hline OPE15-A-01 & $?$ & ?] & 1) & 1 & 1) & 1 & 1 & 1 & 1 & 11 & 1 \\
\hline OPE15-A-02 & $?$ & ? & 1 & 1 & 1 & 1 & 1 & a) & 1 & 1 & 1 \\
\hline OPE15-A-03 & ?) & 2 & 1 & 1 & 1 & 1 & 1 & $1)$ & 1 & 1 & 1 \\
\hline OPE16-A-01 & 0 & 1 & 1 & 1 & 1 & 1 & 1 & 1 & 1 & 11 & 1 \\
\hline OPE16-A-02 & ? & 01 & 11 & $1]$ & 1 & 0 & 1 & 0 & 0 & 1 & 1 \\
\hline OPE 17-A-01 & 1 & 1 & 1 & 1 & 1 & 1 & 1 & 1 & 1 & 1 & 1 \\
\hline OPE17-A-02 & 1) & 1 & 0 & 0 & 1 & 0 & 1 & 1 & 1 & 0 & 0 \\
\hline OPE 17 A-03 & 0 & 0 & of & 0 & 0 & 0 & 0 & 0 & 0 & 0 & 0 \\
\hline OPE 17-A-04 & 1 & 0 & 0 & of & 0 & 0 & 0 & 0 & 0 & 1 & 0 \\
\hline OPE 19-A-01 & $?$ & ?] & 1 & 1 & 0 & 0 & 01 & 1 & 0 & 1 & 0 \\
\hline OPE20-A-01 & 1 & 0) & 0 & 0 & 1 & 0 & 1) & 0 & 1 & 0 & 1 \\
\hline OPE20-A-12 & 0 & 1 & 11 & 1 & 1 & 1 & 1 & 1 & 0 & 1 & 1 \\
\hline OPX01-B-01 & 0 & 0 & 0 & 0 & 0 & 0 & 0 & 0 & 0) & 0 & 0 \\
\hline OPX01-B-02 & 0 & 0 & of & 0 & 1 & 0 & 0 & 0 & 0 & 0 & 0 \\
\hline OPX01-B-03 & 1 & 1] & 1) & 1 & 0 & 1 & 1 & 1 & 1 & 1 & $1]$ \\
\hline OPX01-B-04 & 1] & 1 & $1)$ & 1 & 11 & 1 & 1 & 1 & 1 & 1 & $1]$ \\
\hline OPX01-B-05 & 0 & 0 & 0 & 0 & 0 & 1 & 0 & 0 & 0 & 0 & 0 \\
\hline OPX01-B-06 & 0 & 0 & 0 & 0 & 11 & 0 & 0 & 0 & 0 & 0 & 0 \\
\hline OPX01-B-07 & 1 & 1 & 1 & 1 & 1 & 1 & 1 & 1 & 1 & 1 & 1 \\
\hline OPX01-B-08 & 0 & 0 & 0 & 0 & 0 & 0 & 0 & 0 & 0 & of & (0) \\
\hline OPX01-B-09 & 1 & 1 & 1 & 1 & 1 & 1 & 1 & 1 & 1 & 1 & 1 \\
\hline OPX01-B-10 & 0 & 1) & 0 & 0 & 0 & 0 & 0 & 1 & 0 & 0 & 0 \\
\hline OPX03-B-01 & 1 & 1 & 1 & 1 & 1 & 1 & 1 & 1 & 1 & 1 & 1 \\
\hline OPX03-B-02 & 1 & 1 & 1 & ] & ] & 1 & 0 & 1 & 0 & 1 & 1 \\
\hline OPX04-B-01 & 1 & 1] & $0 \mid$ & 0 & of & 0 & 0 & 1 & 1] & 1) & 1 \\
\hline OPX04-B-02 & 1 & 0 & 0 & 0 & 0 & 0 & 0 & 0 & 0 & 0 & 0 \\
\hline OPX05-B-01 & 1 & 0 & 1) & 1 & 1) & 1] & 0 & 0 & T) & 0 & 0 \\
\hline OPX05-B-02 & 1) & 1 & 0 & 0 & 1 & 1 & 1 & 1 & 1 & 1 & 0 \\
\hline OPX06-B-01 & 0 & 0 & 0 & 0 & 0 & 0 & 0 & 0 & 0 & 0 & 0 \\
\hline OPX07-B-01 & 1 & 0] & 1 & 1 & 0 & 0 & 1 & 0 & 1 & 1 & 0 \\
\hline OPX08-B-01 & of & of & of & 0 & 0 & 0 & of & 0 & 0 & 0 & 0 \\
\hline
\end{tabular}


Anexo 1 - Presença e ausência de 156 bandas de RAPD

(Continuação)

\begin{tabular}{|c|c|c|c|c|c|c|c|c|c|c|c|}
\hline Banda & DG038 & DG039 & DG040 & DGO41 & DG042 & DG043 & DG044 & DG045 & DG046 & DG047 & DG048 \\
\hline OPX08-B-02 & 1 & 1) & 1 & 1 & 0 & 1 & 1 & 1 & 1) & 1 & 1 \\
\hline OPX08-B-03 & 0 & 0 & 0 & 0 & 1 & 0 & 0 & 0 & 0 & 0 & 0 \\
\hline OPX09-B-01 & 1 & 1 & 1 & 1) & 1 & 11 & 11 & 1 & 1 & I) & 1 \\
\hline OPX11-B-01 & 0 & 0 & 1 & 1 & 0 & 0 & 0 & 0 & 0 & 1) & 1 \\
\hline OPX11-B-02 & 0 & 0 & 0 & 0 & 0 & 0 & 1 & 0 & 0 & 0 & 0 \\
\hline OPX12-B-01 & 0 & 0 & 0 & 0 & 0 & 0 & 0 & 0 & 0 & 0 & 0 \\
\hline OPX13-B-01 & 0 & 1 & 0 & 0 & 1 & 1 & 11 & 1 & 0 & 0 & 1 \\
\hline OPX14-B-01 & 0 & 0 & 0 & 0) & 1 & 0 & ? & $?$ & $?$ & $?$ & 0 \\
\hline OPX14-B-02 & 1 & 1 & 1 & 1 & 0 & 1 & ?) & 9 & $?$ & ?) & 1 \\
\hline OPX16-B-01 & 0 & 11 & 0 & 0 & 0 & 0 & ] & 1 & 1 & 1 & 0 \\
\hline OPX16-B-02 & 1 & 1 & 11 & 1 & 1 & 1 & 1 & 1 & 1 & 1 & 1 \\
\hline OPX16-B-03 & $0)$ & 1 & 1 & 11 & 0 & 1 & 11 & 1) & 0 & 0 & 0 \\
\hline OPX17-B-01 & 0 & 0 & 0 & 0 & 0 & 0 & 0 & 0 & 0 & 0 & 0 \\
\hline OPX17-B-02 & 1 & 1 & 1 & 1 & 1 & 1 & 1 & 1 & 1 & 1 & 1 \\
\hline OPX18-B-01 & 0 & 1 & 0 & 0 & 0 & 0 & 0 & 0 & 1 & 0 & 1 \\
\hline OPX19-B-01 & 1 & 0 & 1 & 11 & $1]$ & 11 & 11 & 11 & 1 & 1 & 1 \\
\hline OPX20-B-01 & 0 & 1 & 1 & 1 & 1 & 0 & 1 & 11 & 0 & 1 & 1 \\
\hline OPE07-B-01 & 1 & 0 & 1 & 1 & 1 & 0 & 0 & 0 & 1 & 1 & 1 \\
\hline OPE08-B-02 & 0 & 1 & 0 & 0 & () & 0 & 0 & 01 & 0 & 0 & 0 \\
\hline OPE 10-B-01 & 1 & 0 & 1 & 1 & 1 & 0 & 1 & 0 & 0 & 1 & 1 \\
\hline OPE10-B-02 & 0 & 0 & 0 & 0 & 1 & 0 & 0 & 0 & 0 & 0 & 1 \\
\hline OPE10-B-03 & 0 & 1) & 0 & 0 & 1 & 0) & 01 & 1 & 0 & 0 & 0 \\
\hline OPE10-B-04 & 0 & 1 & 0 & 0) & 0 & 1 & 0 & 11 & 0 & 0 & 1 \\
\hline OPE 11-B-01 & 1 & 1 & 1 & 1 & 0 & 1 & 11 & 1 & 1 & 1 & 1 \\
\hline OPE 12-B-01 & 0 & $?$ & 0 & 0 & 0 & 0 & 0 & 1 & 0 & 0 & 0 \\
\hline OPE 15-B-01 & 0 & 0 & 0 & 0 & 0 & 0 & 0 & 요 & 이 & 0 & 0 \\
\hline OPE 16-B-01 & 0 & 0 & 1 & 1 & 0 & 0 & 1 & 0 & 0 & 0 & 0 \\
\hline OPE $17-B-01$ & 1 & 0 & 0 & 0 & 0 & 1 & 0 & 1 & 1 & 0 & 1 \\
\hline OPE17-B-02 & 1 & 1 & 1 & 11 & 1 & 1 & 1 & 1 & 0 & 1 & $1]$ \\
\hline OPE $17-B-03$ & 0 & 0 & 11 & 11 & 0 & 1 & 0] & 1) & 0 & 0 & 0 \\
\hline OPE17-B-04 & 1 & 0 & 0 & 0 & 1 & 1 & 1 & 0 & 0 & 11 & 1 \\
\hline OPE19-B-01 & 1 & 1 & 0 & 0 & 1 & 0 & 1 & 1 & 1 & 0 & 0 \\
\hline OPE19-B-02 & 0 & 0 & 0 & 0 & 0 & 0 & 0 & 0 & 0 & 0 & 0 \\
\hline OPE20-B-11 & 1 & 요 & 1 & 11 & 1) & 1 & 1 & 0 & 1 & 1) & 1 \\
\hline OPE20-B-02 & 1 & 0 & 0 & 0 & 0 & 0 & 1 & 0 & 1 & 0 & 1 \\
\hline OPE01-AMI & 1 & 1 & $1]$ & 1 & 1 & 1 & 1 & 1 & 1 & $1]$ & 1 \\
\hline OPE01-AM2 & 1 & 1 & 1 & 11 & 1 & 1 & 1 & 1 & 1 & 1 & 1 \\
\hline OPE02-AM1 & 1 & 1 & 1 & 1 & 1 & 1 & 1 & 1 & 1) & 1 & 1 \\
\hline OPE03-AM1 & 1 & 1 & 1 & 1 & 1 & 1 & 1 & 1 & 1 & 1 & 1 \\
\hline OPE03-AM2 & 1 & 1) & 1 & 1 & 1 & 1 & 1 & 1 & 1 & 1 & 1 \\
\hline OPE03-AM3 & 1 & 1 & 1 & 1 & 1 & 1 & 1 & 1 & 1) & 1 & 1 \\
\hline OPE03-AM4 & 11 & 1 & 1) & 1 & 1 & 1 & 1 & 1 & 1 & 1 & 1 \\
\hline OPE04-AM1 & 1 & 1 & 1 & 1 & 1 & 1 & 1 & 1 & 1 & 1 & 1 \\
\hline OPE05-AM1 & 1 & 1 & 1 & 1 & 1 & 1 & 1 & 1 & 1 & 1 & 1 \\
\hline OPE07-AM1 & 1 & 1 & 1 & 1 & $1)$ & 1 & 1 & 1 & 1 & 1 & 1 \\
\hline OPE07-AM2 & 11 & 1 & 1 & 1 & 1 & 1 & 1 & 1 & 1 & 11 & 1 \\
\hline OPE07-AM3 & 1 & 1 & 1 & 1 & 1 & 1 & 1 & 1 & 1 & 1 & 1 \\
\hline OPE07-AM4 & 11 & 1 & 1 & 1 & 1 & 11 & 1 & 1 & 1 & 1 & 1 \\
\hline OPE 10-AMI & 1 & 1 & 1 & 1 & 1 & 1 & 1 & 1 & 1 & 11 & 1 \\
\hline OPE11-AMI & 1 & 1 & 1 & 1 & 1 & 1 & 1 & 1 & 1 & 1 & 1 \\
\hline OPX01-BM1 & 1 & 1 & 1 & 1 & 1 & 1 & 1 & 1 & 1 & $1]$ & 1 \\
\hline OPX01-BM2 & 1 & 1 & 1 & 1 & 1 & 11 & 11 & 11 & 1) & 11 & 1 \\
\hline
\end{tabular}


Anexo 1 - Presença e ausência de 156 bandas de RAPD

(Continuação)

\begin{tabular}{|c|c|c|c|c|c|c|c|c|c|c|c|}
\hline Banda & DG038 & DG039 & DG040 & DG041 & DG042 & DG043 & DG044 & DG045 & DG046 & DG047 & DG048 \\
\hline OPX01-BM3 & 1 & 1 & 1 & 1 & 1 & 1 & 1 & 1 & 1 & I & 1 \\
\hline OPX02-BM1 & 1 & 11 & 1 & 1 & 1 & 1 & 1 & 1 & 1 & 1 & 1 \\
\hline $\mathrm{OPX02- \textrm {BM } 2}$ & 11 & 1 & 1 & 1 & 1 & 1 & 1 & 1 & 1 & 1 & ] \\
\hline OPX03-BM1 & 11 & 1 & 1 & 1 & 1 & 1 & 1 & 1 & 1 & 1 & 1 \\
\hline OPX03-BM2 & 1 & 1 & 1 & 1 & 1 & 1 & 1 & 1 & 1 & 1 & 1 \\
\hline OPX03-BM3 & 1 & 1 & $1)$ & 1 & 1 & 1 & 1 & $1]$ & 1 & 1 & 1 \\
\hline OPX03-BM4 & 1 & 1 & 1 & 1 & 1 & 1 & 1 & 1 & 1 & 1 & 1 \\
\hline OPX04-BM1 & 1 & 1 & 1 & 11 & 1 & 1 & 1 & 1 & 1 & $1)$ & 1 \\
\hline OPX05-BM1 & 1 & 1 & 1 & 11 & 11 & 1 & $1)$ & 1 & 1 & 1 & 1 \\
\hline OPX05-BM2 & 1 & 1 & 1 & 1 & 1 & 1 & 1 & 1 & 1 & 11 & 1 \\
\hline OPX06-BM1 & 1 & 1 & 1 & 1 & 1 & 1 & 1 & 1 & 1 & 1 & 1 \\
\hline OPX06-BM2 & 1 & 1 & 1 & 11 & 1) & 11 & $1)$ & 1 & 1) & 1 & 1 \\
\hline OPX06-BM3 & 1 & 1 & 1 & 1 & 1 & 1 & 1 & 1 & 1 & 1 & 1 \\
\hline OPX06-BM4 & 1 & 1 & 1 & 1 & 11 & 1 & 1 & 1 & 1 & 1 & 1 \\
\hline OPX07-BM1 & 1 & I & 1 & 1 & 1 & 1 & 1 & 1) & 1 & 1 & 1 \\
\hline OPX07-BM2 & 1 & 1 & 1 & 1 & 1 & 1 & 1 & 1 & 1 & 1 & 1 \\
\hline OPX09-BM1 & 1 & 1 & 1 & 11 & 1 & 1 & 1 & 1 & $1)$ & 1 & 1 \\
\hline OPX10-BM1 & 1 & 1 & 11 & 1 & 1 & 1 & 1 & 1 & 1 & 1 & 1 \\
\hline OPX11-BM1 & 1 & 1 & 1 & 1 & 1 & 1 & 1 & 1 & 1 & 1 & 1 \\
\hline OPX11-BM2 & 1 & 1 & 1 & 1 & $1)$ & 1 & 1 & 1 & 1 & 1 & 1 \\
\hline OPX11-BM3 & 1 & 1 & 1 & 1 & 1 & 1 & 1 & 1 & 1 & 1 & 1 \\
\hline OPX11-BM4 & $1)$ & 1 & 1 & 1 & 1 & 1 & 1 & 1 & 1 & 1 & 1 \\
\hline OPX12-BM1 & 1 & 1) & 11 & 1 & 11 & 1 & 1 & 11 & 1 & 1 & 1 \\
\hline OPX12-BM2 & $1)$ & 11 & 1 & 1 & 1 & 1 & 1 & 1 & 1 & 1 & 1 \\
\hline OPX12-BM3 & 1 & 11 & 1 & 1 & 1 & 1 & 1 & 1 & 1 & 1 & 1 \\
\hline OPX12-BM4 & 1 & 1 & 11 & 1 & 11 & 1 & 11 & 1 & 1 & $1)$ & 1 \\
\hline OPX12-BM5 & 1 & 1 & 1 & 1 & 1 & 11 & 1 & 1 & 1 & 1 & 1 \\
\hline OPX12-BM6 & 1 & 1 & 1 & 1 & 1 & 1 & 11 & 1 & 1 & 1 & 1 \\
\hline OPX12-BM7 & 1 & 1 & 1 & 1 & 1 & 1 & 1 & 1 & 11 & I) & 1 \\
\hline OPX13-BM1 & 1 & 1 & 1 & 1 & 11 & 1 & 1 & 1 & 1 & 1 & 1 \\
\hline OPX14-BMI & 1 & 1 & 1 & 1 & 1 & 11 & 1 & 1 & 1 & 1 & 1 \\
\hline OPX14-BM2 & 1 & 1 & 11 & 1 & 1 & 11 & 1 & 1 & 1 & 11 & 1 \\
\hline OPX14-BM3 & 1 & 11 & 1 & 1 & 1 & 1) & 1 & 1 & 1 & $1)$ & 1 \\
\hline OPX15-BM1 & 1 & 1 & $1)$ & $1)$ & 1 & 1) & 1 & 11 & 1 & 1 & 1 \\
\hline OPX15-BM2 & 1 & 11 & 11 & 1 & 1 & 1 & 1 & 1 & 1 & 1 & 1 \\
\hline OPX15-BM3 & 11 & 1 & 1 & 1 & 1 & 1 & 1 & 1 & 1 & 1 & 1 \\
\hline OPX15-BM4 & 1 & 1 & 1 & 1 & 1 & 1 & 1 & 1 & 1 & 1 & 1 \\
\hline OPX17-BM1 & 1 & $1)$ & $1)$ & 1 & 1 & 1 & 1 & 1 & $1)$ & 1 & 1 \\
\hline OPX17-BM2 & 1 & 1 & 11 & 1) & 14 & 1 & 11 & 1 & 1 & 1 & 1 \\
\hline OPX17-BM3 & 1 & 1 & 1 & 1 & 1 & 1 & 1 & 1 & 1 & 1 & 1 \\
\hline OPX18-BM1 & 1 & 1 & 1 & 1 & 11 & 1 & 1 & $1)$ & 1 & 1 & 1 \\
\hline OPX18-BM2 & 1 & 1 & 1 & 1 & 1 & 1 & 1 & 1 & 1 & 1 & 1 \\
\hline OPX19-BMI & 1 & 11 & 11 & 1 & 11 & 1 & 11 & 1 & 1 & 1 & 1 \\
\hline OPE14-BM1 & 1 & 1 & 1 & 1 & 1 & 1 & 1 & 1 & 1 & 11 & 1 \\
\hline OPE 14-BM2 & 1 & 1 & 1 & 1 & 1 & 1 & 1 & 1 & 1 & 1 & 1 \\
\hline OPE14-BM3 & 1 & 1 & 1 & 1 & 1 & 1 & ] & 1 & 1 & 1 & 1 \\
\hline OPE17-BMI & 1 & 1 & 1 & 1 & 1 & 1 & 1 & 1 & 14 & 1 & 1 \\
\hline OPE19-BMI & 1 & 1 & 1 & 1 & 1 & 1 & $1]$ & 1 & 1 & 1 & 1 \\
\hline OPE 19-BM2 & 1 & 1 & 1 & 1) & 1 & 11 & 1 & 1 & 1 & 1 & 1 \\
\hline OPE20-BM1 & $1)$ & 1 & 1 & 1 & 1 & 1 & 1 & 1 & 1 & $1)$ & 1 \\
\hline OPE20-BM2 & $1)$ & 1 & 1 & ] & 1 & 1 & 1 & 1 & 1 & 1 & 1 \\
\hline OPE20-BM3 & 1 & 1 & 11 & 1 & 11 & 11 & 11 & 1 & 1 & 1 & 1 \\
\hline
\end{tabular}


Anexo 1 - Presença e ausência de 156 bandas de RAPD

(Continuação)

\begin{tabular}{|c|c|c|c|c|c|c|c|c|c|c|c|}
\hline Banda & DG049 & DG050 & DG051 & DG052 & DG054 & DG055 & DG056 & DG058 & DG059 & DG060 & DG061 \\
\hline OPX09-A-01 & 1 & 0 & 0 & 0 & 0 & 0 & 0 & 0 & 1 & 0 & \\
\hline OPX14-A-01 & 0 & 1 & II & 1 & 1 & 1 & 0 & 0 & 1 & 1) & 1 \\
\hline OPE01-A-01 & 0 & 0 & 0 & 0 & 0 & 0 & 0 & 1] & 0 & 0 & 0 \\
\hline OPE01-A-02 & of & 0 & 0 & 0 & 0 & 0 & 0 & 0 & 0 & 0 & 0 \\
\hline OPE03-A-01 & 0 & 0 & 1 & 1 & 1 & 1 & 0 & 0 & 0 & 1 & 0 \\
\hline OPE03-A-02 & 1 & 1 & 0 & 1 & 1 & 1 & 0 & 1 & 1 & 1 & 0 \\
\hline OPE03-A-03 & 0 & 1 & $1)$ & 0 & 1 & $1)$ & 0 & 1 & 1 & 0 & 1 \\
\hline OPE05-A-01 & 1 & 1 & 1) & 1 & 1 & 1 & 1 & 1 & 1 & 1 & 1 \\
\hline OPE05-A-02 & 1 & 1 & 1 & 1 & 1 & 1 & 1 & 1 & 1) & 1 & 1 \\
\hline OPE05-A-03 & 1 & 0 & 0 & 1 & I) & 1 & 0 & 1 & 1 & 0 & 0 \\
\hline OPE06-A-01 & 1 & 0 & 0 & 0 & 1 & 0 & 0 & 0 & 1 & o) & 0 \\
\hline OPE07-A-01 & 0 & 0 & 0 & 0 & 0 & 0 & 0 & 0 & 0 & (0) & 1 \\
\hline OPE07-A-02 & 0 & 0 & 0 & 1 & 1 & 1 & 1 & 1 & 0 & 1 & 0 \\
\hline OPE09-A-01 & 1 & ] & 0 & 0 & 0 & 1 & 1 & 1 & 1 & 0 & 0 \\
\hline OPE09-A-02 & 0 & 0 & 1 & 1 & 1 & 1 & 0 & 1 & 0 & 1 & 0 \\
\hline OPE 10-A-01 & 1) & 1 & 0 & 1 & 1 & 1 & 11 & 1 & 1 & 1 & 1 \\
\hline OPE10-A-02 & 0 & 0 & 0 & 0 & 0 & 0 & 0 & 0 & 0 & 0 & 0 \\
\hline OPE10-A-03 & (0) & 0 & 0 & 0 & 0 & 1) & 0 & 0 & 0 & 0 & 0 \\
\hline OPE 10-A-04 & 1) & 0 & 1 & 1 & 0] & 0 & 1 & 1 & 1 & 1 & 0 \\
\hline OPE11-A-01 & 1) & ? & 0 & 1 & ? & ?] & 1 & 1 & 1 & 1 & \\
\hline OPE11-A-02 & 1 & $?$ & 1 & 1 & ?. & ?] & 1 & 1 & $1]$ & 1 & 1 \\
\hline OPE15-A-01 & 1 & 1) & 1 & 1 & 1 & 1 & 1 & 1 & 1 & 1 & 1 \\
\hline OPE15-A-02 & 0 & 1 & 1 & 1 & 1 & 1 & 1 & 1 & 0 & 1 & 0 \\
\hline OPE 15-A-03 & 1 & 11 & 1 & 1 & 1 & 1 & 1 & 1 & 1 & 1 & 1 \\
\hline OPE16-A-01 & II & 1) & 1 & 1] & ? & 1 & 1) & 1 & 1 & 1 & 1 \\
\hline OPE16-A-02 & 0 & 1) & 0 & 0 & ? & ? & 0 & 0 & 0 & 1) & 0 \\
\hline OPE17-A-01 & I & $?$ & 1 & 1 & $?$ & ? & 1 & 1 & 1 & 1 & 0 \\
\hline OPE17-A-02 & 0 & ? & 0 & 1) & 7 & $?$ & 1 & 1 & 0 & 1) & 1 \\
\hline OPE17-A-03 & 0 & ग) & 0 & 0 & ? & ? & 0 & 0 & 0 & 0 & 0 \\
\hline OPE17-A-04 & 0 & ?] & 1) & 0 & ? & $?$ & 0 & $1]$ & 1 & 1) & 1 \\
\hline OPE19-A-01 & 0 & . & 0 & 0 & ?: & ?. & 1 & 0 & 0 & 0 & 0 \\
\hline OPE20-A-01 & 1 & 1 & 0 & 1 & ?] & म) & 1 & 0 & 1 & 1) & \\
\hline OPE $20-A-02$ & 1 & 1 & 1 & 1 & 7) & ? & I & 1 & 1 & 11 & 1 \\
\hline OPX01-B-01 & 0 & 0 & 0 & 0 & 0 & 0 & 0 & 0 & 0 & 0 & 0 \\
\hline $\mathrm{OPX01-B-02}$ & 0 & 0 & 0 & 0 & of & 0] & 0 & 0 & 0 & 0 & 0 \\
\hline OPX01-B-03 & 1 & 1 & 1 & 1 & 1 & 1 & 1 & 1 & 1 & 1 & \\
\hline OPX01-B-04 & 1 & 1 & 1 & 1 & 1 & 1 & I] & 1 & 1 & 1 & \\
\hline OPX01-B-05 & 1 & 1 & 1 & 0 & 0 & 0 & 0 & 0 & 0 & 0 & 0 \\
\hline OPX01-B-06 & 0 & 0 & 0 & 0 & 0 & 0 & 0 & 0 & 0 & 0 & 0 \\
\hline OPX01-B-07] & 1 & 1) & 1) & $1]$ & 1) & 1 & 1 & 1 & 1 & 1 & \\
\hline OPX01-B-08 & 0 & 0 & 0 & 0 & 0 & 0 & 0 & 0 & 0 & 0 & \\
\hline OPX01-B-09 & 1 & 1 & 1 & 1 & I] & 1 & 1 & 1 & 1 & 1 & \\
\hline OPX01-B-10 & 0 & 1 & 0 & 0 & 0 & 0 & 1 & 0 & 0 & 0 & \\
\hline OPX03-B-01 & 1 & 1 & 1 & 1 & 0 & 1 & ]1 & 1 & 1 & 1 & \\
\hline OPX03-B-02 & 1 & 1 & 1 & 1 & 0 & 0 & 1 & 1] & 1 & 1 & \\
\hline OPX04-B-01 & 1) & 1 & 0] & 1 & ]1 & 1 & 1] & 1 & 1 & 1 & \\
\hline OPX04-B-02 & 0 & 1) & 0 & 0 & 7 & 0 & 0 & 1 & 0 & 0 & $\overline{0}$ \\
\hline OPX05-B-01 & 0 & 1 & 1 & 1 & 1 & 1) & 1 & 1 & 0 & 1 & \\
\hline OPX05-B-02 & 1 & 0 & 1 & 1 & 1 & 1 & 1) & 1 & 1 & 1 & \\
\hline OPX06-B-01 & 0 & 0 & 0 & 1 & 0 & 0 & 0 & 0 & 0 & 1 & \\
\hline OPX07-B-01 & 0 & 0 & 0 & 1 & 0 & 1 & 1 & 1 & 0 & 0 & \\
\hline OPX08-B-01 & 0 & 0 & 0 & 0 & 0 & 0 & 0 & 0 & 0 & 0 & \\
\hline
\end{tabular}


Anexo 1 - Presença e ausência de 156 bandas de RAPD

(Continuação)

\begin{tabular}{|c|c|c|c|c|c|c|c|c|c|c|c|}
\hline Banda & DG049 & DG050 & DG051 & DG052 & DG054 & DG055 & DG056 & DG058 & DG059 & DG060 & DG061 \\
\hline OPX08-B-02 & 1 & 1 & 1 & 1 & 1 & 1 & I & I & 1 & 1 & 1 \\
\hline OPX08-B-03 & 0 & of & of & 0 & 0 & 0 & 0 & 0 & 0 & (1) & 0 \\
\hline OPX09-B-01 & 1 & 11 & 11 & 1 & 1 & 1 & 1 & 1 & 11 & 1 & 1 \\
\hline OPX11-B-01 & 0 & 1 & 0 & 0 & 0 & 0 & 0 & ] & 0 & 0 & 0 \\
\hline OPX11-B-02 & 0 & 0) & 0 & 요 & 0 & 0 & 1 & 0 & 0 & of & 0 \\
\hline OPX12-B-01 & 0 & 0 & 0 & 0 & 0 & 0 & 0] & 0 & 0 & 0 & 0 \\
\hline OPX13-B-01 & 1 & 0 & ]) & 0 & 0 & 0 & 0 & (0) & 1) & 11 & 0 \\
\hline OPX14-B-01 & 요 & 0 & 0 & 0 & 0 & 0) & 0 & 0 & 0 & 0 & 0 \\
\hline OPX14-B-02 & 1 & 1 & 1 & 1 & 1 & 1 & 1 & 1 & 1 & 1 & 1 \\
\hline OPX16-B-01 & 11 & 1 & 0 & 0 & 1 & 1 & 1 & 1 & 1 & 1 & 1 \\
\hline OPX16-B-02 & 1 & 1 & 1 & 1 & 11 & 0 & 1 & 1 & 1 & 1 & 1 \\
\hline OPX16-B-03 & 0 & 1 & 11 & 0 & 0 & $1]$ & 0 & 0 & 0 & 0 & 1 \\
\hline OPX17-B-01 & 0 & 0 & 0 & 0 & 0 & 0 & of & 0 & 0 & 0 & 1 \\
\hline OPX17-B-02 & 1 & 1 & 11 & 1 & 1 & 1 & 1 & 1 & 11 & 1 & 1 \\
\hline OPX18-B-01 & 1 & 0 & 0 & 0 & 0 & 0 & 0 & 0 & 1 & 11 & 1 \\
\hline OPX19-B-101 & 1 & 0 & 1 & 1 & 1 & 1 & 0) & 1 & $?$ & $?$ & 1 \\
\hline $\mathrm{OPX} 20-\mathrm{B}-01$ & ]) & 0 & 0 & 1 & 1 & 1 & 1 & 0 & 1 & 1 & 1 \\
\hline OPE07-B-01 & of & 1 & 0 & 1 & 0 & 0 & 11 & 01 & 0 & 0 & 0 \\
\hline OPE08-B-02 & 0 & 11 & 0 & 1 & 이 & of & 0) & 0 & 0 & 7 & ] \\
\hline OPE10-B-01 & 1 & 0 & 0 & 1 & 1 & 1 & 1 & 1 & 1 & $?$ & 1 \\
\hline OPE10-B-02 & 0 & 0 & 0 & 0 & 0 & 1 & 0 & 1 & 0 & 0 & 0 \\
\hline OPE 10-B-03 & 0 & 0 & of & 0 & 0) & 0 & 0 & 0] & of & 0 & 1 \\
\hline OPE10-B-04 & 0 & 1 & 1) & 0 & 1 & 1 & 0 & 1) & ?) & 1 & 1 \\
\hline OPE $11-B-01$ & 1 & 1 & 11 & 이 & 1 & 1 & 0 & 1 & 1) & 3 & 0 \\
\hline OPE12-B-01 & 0 & 1 & 요 & 0 & 요 & 0 & of & 0 & 0 & 0 & $?$ \\
\hline OPE15-B-01 & 0 & 0 & 0 & 0 & 0 & 0 & 0 & 0 & 0 & 0 & 1 \\
\hline OPE16-B-01 & 1 & 0 & 0 & 0 & $?$ & ] & 11 & 1 & 1 & 0 & 1 \\
\hline OPE 17-B-01 & 0) & 1 & 1 & 요 & 1 & 0 & 0 & 1 & 0 & 1 & 1 \\
\hline OPE17-B-02 & 11 & 1 & 1 & 1 & 0 & 1 & 1 & 1 & 1 & 1 & 1 \\
\hline OPE17-B-03 & 0 & 0 & 1 & 0 & 0 & 1 & 0 & 1 & 0 & 0) & 0 \\
\hline OPE17-B-04 & of & of & of & 0 & 1 & ()) & 1 & 1 & 요 & 0 & 0 \\
\hline OPE19-B-01 & 0 & 1 & 0 & 1 & 1 & 1 & 11 & 1 & 0 & 1 & 1 \\
\hline OPE19-B-02 & 0 & 0 & 0 & of & 0 & of & 0 & 0 & 0 & 0) & 0 \\
\hline OPE $20-B-01$ & 1 & 1 & 1 & 1 & 1 & 0 & 1 & 1 & 1 & 1 & 1 \\
\hline OPE20-B-02 & 1 & 1 & 0 & 1 & 1 & 0 & 1 & 0 & 1 & 1 & 1 \\
\hline OPE01AM1 & 1 & 1 & 1 & 1 & 1 & 1 & $1]$ & 1 & 1 & 1 & 1 \\
\hline OPEO1AM2 & 1 & 1 & 11 & 1 & 1 & 1 & 1 & 1 & 1 & 1 & 1 \\
\hline OPE02AMI & 1 & 1 & 11 & 1 & 1 & 1 & 1 & 1 & 1 & 1 & 1 \\
\hline OPE03AM1 & 1 & $1)$ & 1 & 11 & 1 & 1 & 1 & 1 & 1 & 1 & 1 \\
\hline OPE03AM2 & 1 & 1 & 1 & 1 & 1 & 1 & 1 & 1 & 1 & 1 & 1 \\
\hline OPE03AM3 & 1 & 1 & 1 & 1 & 1 & 1 & 1 & 1 & 1 & 1 & 1 \\
\hline OPEO3AM4 & 1) & 1 & 1 & 1 & 1 & 1 & 1 & 1 & 1 & 1 & 1 \\
\hline OPEO4AM1 & 1 & 1 & 1 & 1 & 1 & 1 & 1 & 1 & 1 & 11 & 1 \\
\hline OPE05AM1 & 1 & 1 & 1 & 1 & 1 & 1 & 1 & 1 & 1 & 1 & 1 \\
\hline OPE07AM1 & 1 & 1 & $1)$ & 1 & $1)$ & 1 & 1 & 1 & 1 & 1 & 1 \\
\hline OPE07AM2 & 1 & 1 & 1 & 1 & 1) & $1)$ & 1 & 1 & 11 & 11 & 1 \\
\hline OPE07AM3 & 1 & 1 & 1 & 1 & 1 & 1 & 1 & 1 & 1 & $1)$ & 1 \\
\hline OPE07AM4 & 1 & 1 & 11 & 1 & 1 & 1 & 1 & 1 & 1 & $1)$ & 1 \\
\hline OPE10AM1 & 1 & 1 & 1 & 1 & 1 & 1 & 1 & 1 & 1 & 1 & 1 \\
\hline OPE11AMI & 1 & 1 & 1) & 1 & 1 & 1 & 1 & $1)$ & 1 & 1 & 1 \\
\hline OPX01BM1 & 11 & 1 & 1 & 1 & 1 & $1)$ & 1 & 1 & $1)$ & 1 & 1 \\
\hline OPX01BM2 & 11 & 1 & 11 & 11 & 1 & 1 & 1 & 1 & 1 & 1 & 1 \\
\hline
\end{tabular}


Anexo 1 - Presença e ausência de 156 bandas de RAPD

(Continuação)

\begin{tabular}{|c|c|c|c|c|c|c|c|c|c|c|c|}
\hline Banda & DG049 & DG050 & DG051 & DG052 & DG054 & DG055 & DG056 & DG058 & DG059 & DG060 & DG061 \\
\hline OPX01BM3 & 1 & 1 & 1 & ] & 1 & 1 & 1 & 1 & 1 & 1 & 1 \\
\hline OPX02BMI & 1 & 11 & 1 & 1 & 1 & 1 & 1 & 11 & 1 & 1 & 1 \\
\hline OPX02BM2 & 1 & 1 & 1 & 1 & 1 & 1 & 1 & 11 & 1 & 1 & 1 \\
\hline OPX03BM1 & 1 & 1 & 1 & 1 & 1 & 1 & 1 & 1 & 1) & 1) & 1 \\
\hline OPX03BM2 & 1 & 1 & 11 & 1 & 1 & 1 & 1 & 1 & 1 & 1 & 1 \\
\hline OPX03BM3 & 1 & 1 & 1 & 1 & 1 & 1 & 1 & 1 & 1 & 1 & 1 \\
\hline OPX03BM4 & 1 & 1) & 1 & 1 & 11 & 1) & 1 & 1) & 1 & 1 & 1 \\
\hline OPX04BMI & 11 & 1 & 1 & 1 & 1 & 1 & 1 & 1 & 1 & 1 & 1 \\
\hline OPX05BM1 & 1 & 1) & I) & 1 & 1 & 1 & 1 & 1 & 1 & 1 & 1 \\
\hline OPX05BM2 & 1 & 1 & 1 & 1 & 1 & 1 & 11 & 1 & 1 & $1]$ & 1 \\
\hline OPX06BM1 & 1 & 1 & 1 & 1 & 1 & 1 & 1 & 1 & 1 & 1 & 1 \\
\hline OPX06BM2 & 1 & 1 & 1 & 1 & 11 & 1 & 1 & 1 & 1 & 1 & 1 \\
\hline OPX06BM3 & 1 & 1 & 1 & 1 & 1 & 1 & 1 & 1 & 1 & 1 & 1 \\
\hline OPX06BM4 & 1 & 1 & 1 & 1 & $1)$ & 1 & 1 & 1 & 1 & I) & 1 \\
\hline OPX07BM1 & 1 & 1 & 1 & 1) & 1 & 11 & 1 & 1 & 1 & 1 & 1 \\
\hline OPX07BM2 & 11 & 1 & 1 & 11 & 1 & 11 & 1 & 1 & 1 & 1 & 1 \\
\hline OPX09BM1 & 1 & 1 & 1 & 1 & 1 & 1 & 1 & 1 & 1 & 1 & 1 \\
\hline OPX10BM1 & 11 & 1 & 1 & 11 & 1 & 11 & 1) & 1 & 1) & 1 & 1 \\
\hline OPX11BM1 & 1 & 1 & 1 & 1 & 1 & 1 & 1 & 1 & 1 & 1 & 1 \\
\hline OPX11BM2 & 1 & 1 & 1 & 1 & 1 & 1 & 1 & 1 & 1 & 1 & 1 \\
\hline OPX11BM3 & 1 & 1) & 1 & 1 & 1 & 1 & 1 & 1 & ] & 1 & 1 \\
\hline OPX11BM4 & 1 & 1 & 1 & 1 & 1 & 1 & 1 & 1 & 1 & 1 & 1 \\
\hline OPX12BM1 & 1 & 1 & 1 & 1 & 1 & 1 & 1 & 1 & 1 & 1 & 1 \\
\hline OPX12BM2 & 1 & 11 & 1) & 1 & 1 & 1 & 1 & 1 & 1 & 1 & 1 \\
\hline OPX12BM3 & 1 & 1 & 1 & 1 & 1 & 1 & 11 & 1 & 1 & 1 & 1 \\
\hline OPX12BM4 & 1 & 1 & 1 & 1 & 1 & 1 & 1 & 1 & 1 & 1 & 1 \\
\hline OPX12BMS & 1 & 1 & 1 & 1 & 1 & 1 & 1 & 1 & 1) & 1 & 1 \\
\hline OPX12BM6 & 1 & 1 & 1 & 1 & 11 & 1 & 1 & 1 & $1]$ & 1 & 1 \\
\hline OPX12BM7 & 1) & 1 & 1 & 1 & 1 & 1 & 11 & 1 & 1 & 1 & 1 \\
\hline OPX13BM1 & 1 & 1 & 1 & 1 & 1 & 1 & 1 & 1 & 1 & 1 & 1 \\
\hline OPX14BM1 & 1 & 11 & 1 & 1 & 1 & 1 & 11 & 1 & 1 & 1 & 1 \\
\hline OPX14BM2 & 1 & 1 & 11 & 1 & 1 & 1 & 1 & 1 & 1 & 1 & 1 \\
\hline OPX14BM3 & 1 & 1 & 1 & 1) & 1 & 1 & 1 & 1 & 1 & 1 & 1 \\
\hline OPX15BM1 & 1 & 1 & 1 & 1 & 1 & 1 & 1 & 1 & 1 & 1 & 1 \\
\hline OPX15BM2 & 11 & 1 & 1 & 1 & 1 & 1 & 1 & 1 & 1 & 1 & 1 \\
\hline OPX15BM3 & 1 & 1 & 1 & 1 & 1 & 1 & 1 & 1 & 1 & 1 & 1 \\
\hline OPX15BM4 & 1 & 1) & 1 & 1 & 1 & 1 & 1) & 1 & 1 & 1 & 1 \\
\hline OPX17BM1 & 1 & 1 & 1 & 1 & 1 & 1 & 1 & 1 & 1 & 1 & 1 \\
\hline OPX17BM2 & 1 & 1 & 1 & 1 & 1 & 1 & 1 & 1 & 1 & 1 & 1 \\
\hline OРX17BM3 & 1 & 1 & $1)$ & 1 & 1 & 1 & 1 & 1 & 1 & 1 & 1 \\
\hline OPX18BMI & 1 & 1 & 1 & 1 & 1 & 1 & 1 & 1 & 1 & 1 & 1 \\
\hline OPX18BM2 & 1 & 1 & 11 & 1 & 1 & 1 & 1 & 1 & 1 & 1 & 1 \\
\hline OPX19BM1 & 1 & 1 & 1 & 1 & 11 & 1 & 1 & 1 & 1 & 1 & 1 \\
\hline OPE14BM1 & 1 & 1 & 1 & 1 & 1) & 1 & 1 & 1 & 1 & 1 & 1 \\
\hline OPE 14BM2 & 1 & 1 & 1 & 1 & 1 & 1 & 1 & 1 & 1 & 1 & 1 \\
\hline OPE14BM3 & 1 & 1 & 1 & 11 & 1 & 11 & 1 & 1 & 1) & 1 & 1 \\
\hline OPE17BM1 & 1 & 1 & 1 & 1 & 1 & 1 & 1 & 1 & 1 & 1 & 1 \\
\hline OPE19BM1 & 1 & 1 & 1 & 1 & 1 & 1 & 1 & 1 & 1 & 1 & 1 \\
\hline OPE19BM2 & 1 & 11 & 1 & 1 & 1 & 1 & 1 & 1 & 1 & 1 & 1 \\
\hline OPE20BMI & 1 & 1 & 1 & 1 & 1 & 1 & 1 & 1 & 1 & 1 & 1 \\
\hline OPE20BM2 & 1 & 1 & 1 & 1 & 1 & 1 & 1 & 1 & 1 & 1 & 1 \\
\hline OPE20BM3 & 1 & 11 & 1 & 1 & 1 & 1 & 1 & 1 & 1 & 1 & 1 \\
\hline
\end{tabular}


Anexo 1 - Presença e ausência de 156 bandas de RAPD

(Continuação)

\begin{tabular}{|c|c|c|c|c|c|c|c|c|c|c|c|}
\hline Banda & \begin{tabular}{|l|l|} 
DG062 \\
\end{tabular} & DG065 & DG067 & DG068 & DG069 & DG070 & DG073 & DG111 & DG112 & DG113 & DG114 \\
\hline OPX09-A-01 & 0 & 1) & 1 & 1 & 0 & 0 & 0 & of & 0 & 1 & 0 \\
\hline OPX14-A-01 & 1 & 1 & 1 & 11 & 1 & 0 & 0 & 1 & 1 & 1 & \\
\hline OPE01-A-01 & 1 & 1 & 0 & 0 & 0 & 0 & 1 & 0 & 0 & 1 & 1 \\
\hline OPE01-A-02 & 0 & 1 & 0 & 0 & 0 & 1 & 0 & 0 & 0 & 0 & 0 \\
\hline OPE03-A-01 & 0 & 9 & of & 0 & 1 & 9 & 요 & 0 & 0 & 1 & 3 \\
\hline OPE03-A-02 & of & 1 & of & $1)$ & 0 & 0 & 11 & $1]$ & 1 & $1]$ & \\
\hline OPE03-A-03 & 1 & 1 & 1 & 1 & 1 & 2 & 0 & 1 & 0 & 0 & \\
\hline OPE05-A-01 & 1 & 1 & I) & 11 & 0 & ?. & 1 & 1) & 11 & 1 & 0 \\
\hline OPE05-A-02 & 1 & 1 & 1 & 1 & 1 & 0 & 1 & 1 & 1 & 1 & 1 \\
\hline OPE05-A-03 & 1 & 0 & 0 & 0 & 0 & $?$ & 0 & 0 & 1 & 0 & 0 \\
\hline OPE06-A-01 & 0 & 0 & 0 & $1)$ & 0 & 0 & 1 & 0 & 0 & 0 & 0 \\
\hline OPE07-A-01 & 0 & 0 & 1 & 1 & 0 & $?$ & 1 & 0 & 0 & 0 & 1 \\
\hline OPE $07-\mathrm{A}-02$ & 1 & 1 & 0 & 0 & 1 & 2) & 1 & 1 & 1 & 1 & \\
\hline OPE09-A-01 & 1 & 1 & 0 & 0 & 0 & $?$ & 0 & 0 & 1 & 1 & 0 \\
\hline OPE09-A-102 & 1 & 0 & 0 & 0 & 1 & 3 & 0 & () & 0 & 0 & \\
\hline OPE10-A-01 & 1 & 1) & 1 & 1 & 1] & ?] & 1 & 7 & 0 & 1 & \\
\hline OPE10-A-02 & 0 & 0 & 0 & 1 & 0 & 21 & 0 & ?. & 0 & 0) & \\
\hline OPE10-A-03 & 1 & 0 & 0 & 1 & 0 & $?$ & 0] & 2 & 1 & 0 & 1 \\
\hline OPE 10-A-04 & 1 & 0 & 0 & 0 & 0 & 2 & 1 & ? & 0 & 0 & 0 \\
\hline OPE11-A-01 & 1 & I) & 1 & $1]$ & 1 & 1 & 1 & 1 & 1 & 1 & 1 \\
\hline OPE11-A-02 & 1 & 1 & 1) & 0 & 1 & 1 & 1) & 1) & 1 & ]) & 1 \\
\hline OPE15-A-01 & 1 & 1 & 1 & 1 & 1 & 0 & 0 & 1 & 0 & 1 & 1 \\
\hline OPE15-A-02 & 1 & 1 & 0 & of & 1 & 11 & 1 & 1 & 1 & 1 & 1 \\
\hline OPE15-A-03 & 1 & 1 & 1 & 1 & 1 & 1 & 0 & 1) & 1 & 1 & 1 \\
\hline OPE16-A-01 & 1) & 1 & 11 & 1 & 1 & 1 & 1 & 0 & 0 & 1 & \\
\hline OPE16-A-02 & 0 & 1 & 0 & 0 & 0 & 1 & 0 & 1 & 0 & 1 & 0 \\
\hline OPE17-A-01 & 1 & 0 & 0 & 0 & of & 0 & 1 & 1 & 1 & 1 & \\
\hline OPE17-A-02 & 1 & 11 & 1 & 1 & 1 & 1 & 1 & 1 & 1 & 1 & 1 \\
\hline OPE17-A-103 & 0 & 0 & 0 & 0 & 0 & of & of & 0 & 0 & 1 & 0 \\
\hline OPE17-A-04 & 0 & 1) & 1 & 1 & 1 & 11 & 1 & 1] & 1) & 1 & 0 \\
\hline OPE19-A-01 & 0 & 11 & 0 & 1 & 1 & 1 & 1 & 1 & 0 & 0 & \\
\hline OPE20-A-01 & 0 & 1 & 1 & 0 & 1 & 0 & 0 & 0 & 0 & 0 & 0 \\
\hline OPE20-A-02 & 1 & 1 & 1) & 11 & 1 & 1 & 1 & 1 & 1) & 1 & \\
\hline OPX01-B-01 & 0 & 0 & 0 & 0 & 1 & 1 & 0 & 0 & 0 & 0 & 1 \\
\hline OPX01-B-02 & 0 & 0 & 0 & 0 & 0 & 0 & 0 & 0 & 0 & of & 0 \\
\hline OPX01-B-03 & 1 & 1 & 1 & 1 & 0 & 0 & 1 & 1 & 1 & 1 & 0 \\
\hline OPX01-B-04 & 1 & 11 & 1 & 11 & 1 & 1 & 1 & 1 & 1 & 1 & \\
\hline OPX01-B-05 & 0 & 0 & 0 & 0 & 0 & 0 & 0 & 0 & 0 & 0 & 0 \\
\hline OPX01-B-06 & of & 0 & 0 & 0 & 1 & 1 & 0 & 0 & 0 & 0 & \\
\hline OPX01-B-07 & 1 & 1 & $1)$ & 1 & 1 & 1 & 1 & 1 & 1 & ] & \\
\hline OPX01-B-08 & of & 1 & 1 & 0 & 1 & 0 & 0 & 이 & 0 & 0 & \\
\hline OPX01-B-09 & $1]$ & 1 & 0 & 1 & 1 & 1 & 1 & 1 & 1 & 1 & \\
\hline OPX01-B-10 & 0 & 0 & 1 & 1 & 0 & 0 & 0 & 0 & 0 & 0 & \\
\hline OPX03-B-01 & 1 & 1 & 1 & 1 & 1 & 1] & 1 & 1 & 1 & 1 & \\
\hline OPX03-B-02 & 1 & 1 & 1 & ] & 1 & ]) & I) & 1 & 0 & 1 & \\
\hline OPX04-B-01 & 1 & 11 & 1 & 1 & 1 & 0 & 1 & 1 & 1 & 1 & \\
\hline OPX04-B-02 & 1 & 0 & 0 & 0 & 0 & 1 & 0 & 1 & 1 & 1 & \\
\hline OPX05-B-01 & 1 & 0 & 1 & 0 & 0 & 0 & 1 & 1 & 1 & 1 & \\
\hline OPX05-B-02 & 1 & 1 & 1 & 1 & 1 & 1 & 1 & 1 & 1 & 1 & \\
\hline OPX06-B-01 & 0 & 0 & 0 & 0 & 0 & 0 & 0 & 0 & 0 & 0 & \\
\hline OPX07-B-01 & 1 & 0 & 0 & 0 & 0 & 1 & 1 & 1 & 1 & 1 & \\
\hline OPX08-B-01] & 0 & 이 & 01 & 01 & 1] & 1 & 이 & 의 & 0 & 01 & \\
\hline
\end{tabular}


Anexo 1 - Presença e ausência de 156 bandas de RAPD

(Continuação)

\begin{tabular}{|c|c|c|c|c|c|c|c|c|c|c|c|}
\hline Banda & DG062 & DG065 & DG067 & DG068 & DG069 & DG070 & DG073 & DG111 & DG112 & DG113 & DG114 \\
\hline OPX08-B-02 & 1 & 1 & I & 1 & 0 & 0 & 1 & 1 & 1 & 1 & 0 \\
\hline OPX08-B-03 & 0 & 0 & 0 & 0 & 0 & 0 & 0 & 0 & 0 & 0 & 0 \\
\hline OPX09-B-01 & 1 & 1 & 1 & 1 & 0 & 0 & 1 & 1 & 1 & 1 & 0 \\
\hline OPX11-B-01 & 1 & 0 & 0 & 0 & 0 & 0 & 0 & 0 & 0 & 0 & 0 \\
\hline OPX11-B-02 & 0 & 0 & 0 & 0 & 1 & 1 & 1 & 0 & 0 & 0 & 0 \\
\hline OPX12-B-01 & 0 & 0 & 0 & 0 & 1 & 1 & 0 & 0 & 0 & 0 & ] \\
\hline OPX13-B-01 & 0 & 1 & 0 & 1 & 1) & 0 & 1 & 1 & 0 & 0 & 0 \\
\hline OPX14-B-01 & 0 & 0 & 0 & 1 & 1 & 0 & 0 & 0 & 0 & 0 & 1 \\
\hline OPX14-B-02 & 1 & 1 & 1 & 0 & 0 & 1 & 1 & 1 & 1 & 1 & 0 \\
\hline OPX16-B-01 & 1 & 1 & 1 & 1 & 1 & 1 & 1 & 0 & 0 & 0 & 0 \\
\hline OPX16-B-02 & 1 & 1 & 1 & 1 & 1] & 0 & 1 & 1 & 1] & 11 & 0 \\
\hline OPX16-B-03 & 0 & 1 & 1 & 1 & 1] & 0 & 7 & 1 & 0 & 1) & 1 \\
\hline OPX17-B-01 & 0 & 0 & 1 & 0 & 0 & 0 & 0 & 0 & 0 & 0 & 0 \\
\hline OPX17-B-02 & 1 & 1 & 1 & 1 & 1 & 1) & 1 & 1 & 1 & 1] & 1 \\
\hline OPX18-B-01 & 0 & 1 & 1 & 0 & 0 & 0 & 1 & 0 & 0 & 0 & 0 \\
\hline OPX19-B-01 & 1 & 0 & 1 & 1 & 1 & 1 & 0 & 1 & 1. & 1 & 1 \\
\hline OPX20-B-01 & 0 & 1 & 1 & 1 & 1 & ] & 1 & 0 & 0 & 1 & 0 \\
\hline OPE07-B-01 & 0 & 0 & 0 & a) & 1 & of & 0 & I & 0 & 0 & 1 \\
\hline OPE08-B-02 & 0 & 1 & 0 & 0 & 0 & ? & ? & 1 & $?$ & 1 & 0 \\
\hline OPE10-B-01 & 1 & 2 & 1 & 0 & 1 & $?$ & 1 & 1 & 0 & 1 & 0 \\
\hline OPE10-B-02 & 1 & 0 & (1) & 0 & 0 & 0 & 0 & 0 & 0 & 0 & 0 \\
\hline OPE10-B-03 & 0 & 0 & 1 & 1 & 0 & 0 & 0 & 0 & 0 & 0 & 1 \\
\hline 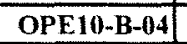 & 1 & 7 & 1 & $\pi$ & 0 & $?$ & 0 & 0 & $?$ & 0 & 0 \\
\hline OPE11-B-01 & 1 & 1 & 0 & 1 & 1 & $?$ & 1 & 1 & 1 & 1 & 1 \\
\hline OPE12-B-01 & 0 & 0 & 0 & 1 & 0 & 0 & 1 & 0 & $?$ & 0 & $?$ \\
\hline OPE15-B-01 & 0 & 0 & 1 & 0 & 1 & 0 & 0 & 0 & 0 & 0 & 0 \\
\hline OPE16-B-01 & 0 & 0 & 1 & 0 & 0 & 1 & 0 & 1 & $?$ & 0 & 1 \\
\hline OPE17-B-01 & 1 & 1 & 1] & 1 & 0 & 1 & 1. & 0 & 1 & 1 & 1 \\
\hline OPE17-B-102 & 0 & 1) & 1 & 1 & 1 & 1) & ] & ]1] & 7 & 1 & $\overline{0}$ \\
\hline OPE17-B-03 & 1 & 0 & 0 & ]1 & 1 & 0 & 0 & 1 & 0 & 1 & 0 \\
\hline OPE17-B-04 & 1 & 0 & 0 & 0 & 1 & 0 & 0 & 0 & 1 & 0 & 0 \\
\hline OPE19-B-01 & 1 & 1 & 1 & 1 & 1 & 1 & 1 & 1 & 1 & 1 & 1 \\
\hline OPE 19-B-02 & 0 & 0 & 0 & 0 & 0 & 0 & 0 & 0 & 0 & 0 & 0 \\
\hline OPE20-B-01 & 1 & 1 & ] & 0 & 0 & 1 & 1 & 0 & 1 & 1 & \\
\hline OPE20-B-02 & 0 & 1 & I & 0 & 1 & 0 & 0 & 0 & 1 & 0 & 0 \\
\hline OPE01AM1 & 1 & 1 & 1 & 1 & 1 & 1 & 1 & 1 & 1 & 1 & 1 \\
\hline OPE01AM2 & 1 & 1 & 1 & 1 & 1 & 1 & 1 & 1 & 1 & 1 & 1 \\
\hline OPE02AM1 & 1 & 1 & 1 & 1 & 1 & 1 & 1 & 1 & 1 & 1 & 1 \\
\hline OPE03AM1 & 1 & 1 & 1 & 1 & 1 & 1 & 1 & 1 & 1 & 1 & 1 \\
\hline OPE03AM2 & 1 & 1 & 1 & 1 & 1 & 1 & 1 & 1 & 1 & 1 & 1 \\
\hline OPE03AM3 & 1 & 1 & 1 & 1 & 1 & 1 & 1 & $1]$ & 1 & 1 & 1 \\
\hline OPE03AM4 & 1 & 1 & 1 & 1 & 1 & 1 & 1 & 1 & 1 & 1 & 1 \\
\hline OPE04AM1 & 1 & 1 & 1 & 1 & 1 & 1 & 1 & 1 & 1 & 1 & 1 \\
\hline OPE05AM1 & $\pi$ & I & 1 & 1 & 1 & 1 & 1 & 1 & 1 & ] & 1 \\
\hline OPE07AM1 & 7 & 1) & 1 & 1 & 1 & 1) & 1 & 1 & 1 & 1 & \\
\hline OPE07AM2 & 1 & 1 & 1 & 1 & 1 & 1 & 7 & 1 & 1 & 1 & \\
\hline OPE07AM3 & 1 & 1 & 1 & 1 & 1 & 1 & 1 & 1 & 1 & 1 & \\
\hline OPE07AM4 & 1 & 1 & 1 & 1 & 1 & 1 & 1) & 1 & 1 & 1 & \\
\hline OPE10AM1 & 1 & 1 & 1 & 1 & 1 & 1 & 1 & 1 & 1 & 1 & \\
\hline OPE11AM1 & 1 & 1 & 1 & 1 & 1 & 1 & 1 & 1 & 1 & 1 & \\
\hline OPX01BM1 & 1 & 1 & 1 & 1 & 1) & 1 & 1 & 1 & 1 & 1 & \\
\hline OPX01BM2 & 1 & 1 & 1 & 1 & 1 & 1 & 1 & 1 & 1 & 1 & \\
\hline
\end{tabular}


Anexo 1 - Presença e ausência de 156 bandas de RAPD

(Continuação)

\begin{tabular}{|c|c|c|c|c|c|c|c|c|c|c|c|}
\hline \begin{tabular}{c|} 
Banda \\
\end{tabular} & DG062 & DG065 & $\begin{array}{l}\text { DG067 } \\
\end{array}$ & $\begin{array}{l}\text { DG068 } \\
\end{array}$ & DG069 & DG070 & DG073 & DG111 & DG112 & DG113 & DG114 \\
\hline OPX01BM3 & 1 & & & 1) & I & I & 1 & 1 & 1 & 1 & \\
\hline OPX02BMI & 1] & $\pi$ & 1) & 1) & 1 & 1 & 1 & 1 & 1 & 1 & 1 \\
\hline OPX02BM2 & 1) & 1 & 1 & 1 & 1] & 1 & 1 & 1 & $1]$ & 1 & 1 \\
\hline OPX03BMI & 1 & 1 & 1 & 11 & 1 & 1 & 1 & 1 & 1 & $1)$ & 1 \\
\hline OPX03BM2 & 1) & 1 & 1 & 1 & 1 & 1 & 1 & 1 & 1 & 1 & 1 \\
\hline OPX03BM3 & 1 & 1 & 1 & 1) & 1 & 1 & 1 & 1. & 1 & 1 & 1 \\
\hline OPX03ВM4 & $1)$ & 11 & 1 & 11 & $1)$ & 1 & 1. & 1 & 1 & 1 & 1 \\
\hline OPX04BM1 & 1 & 1 & 1 & 1 & 1 & 1 & 1 & $1]$ & 1 & 1 & 1 \\
\hline OPX05BM1 & 1 & 1 & 1 & 1 & 1) & 1 & 1 & 1 & 1 & 1 & 1 \\
\hline OPX05BM2 & 1 & 1 & 1 & 1 & 1 & 1 & 1 & 1 & 1 & ] & 1 \\
\hline OPX06BM1 & 1 & 1) & 1 & ] & 1 & 1 & 1 & 1 & 1 & 1 & 1 \\
\hline OPX06BM2 & 1 & 1 & 1 & 11 & 11 & 1 & 1 & 1 & 1 & 1 & 1 \\
\hline OPX06BM3 & 1 & 1 & $1]$ & 1 & 1 & 11 & i) & 1 & 1 & 1 & \\
\hline OPX06BM4 & 1 & 1 & 1) & 1 & 1 & I) & 1 & 1 & 1 & 1 & \\
\hline OPX07BM1 & 1 & 1 & 1 & 1 & 1 & 1 & 1 & 1 & 1 & 1 & \\
\hline OPX07BM2 & 1 & 1 & 1 & 1 & 1 & 1) & 1 & 1 & 1 & 1 & \\
\hline OPX09BM1 & 1 & 1 & 1) & 1 & 1) & 1 & 1 & 1 & $1]$ & 1 & \\
\hline OPX10BM1 & 11 & 1 & $1)$ & 11 & $1)$ & 1) & 1) & 1 & 1 & 1 & \\
\hline OPX11BM1 & 1 & 1 & 1 & 1 & 1 & 1 & 1 & 1 & 1 & 1 & \\
\hline OPX11 BM2 & 1 & 1 & 1 & 11 & 1 & 1 & 1 & 1 & 1 & 1 & \\
\hline OPX11BM3 & 11 & 1 & 1 & $1]$ & 1 & 1 & 1 & 1 & 1 & 11 & \\
\hline OPX11BM4 & 1] & 1 & 1 & 1 & 1 & 1 & 1 & 1 & 1 & 1 & \\
\hline OPX12BM1 & 1 & 1 & 1 & 1 & 1 & 1 & 1 & 11 & 1 & 1 & \\
\hline $\mathrm{OPX} 12 \mathrm{BM} 2$ & 1 & 1 & 1 & 1 & 1 & 1 & 1 & 1 & 1 & 1 & \\
\hline OPX12BM3 & ] & 1) & 1 & 1 & 1 & 1 & 1 & 1 & 1 & 1 & \\
\hline OPX12BM4 & 1 & 11 & 1 & 1) & 1 & 1 & 1 & 1 & 1 & 1 & 1 \\
\hline OPX12BM5 & 1 & 1 & 1 & 1 & 1 & 1 & 1 & 1 & 1 & 1 & 1 \\
\hline OPX12BM6 & 1 & 1 & 1 & 1 & 1 & 1 & 1 & 1 & 1 & 1 & \\
\hline OPX12BM7 & 1 & 1 & ]) & 1) & 1) & 1) & 1 & ] & II & 1 & \\
\hline OPX13BM1 & 1 & 1) & 1) & l) & 1 & 1 & 1 & 1 & 1 & 1 & \\
\hline OPX14BM1 & 1 & 1 & 1 & 1 & 1 & 1 & 1 & 1 & 1 & 1) & \\
\hline OPX14BM2 & 1 & 1 & 1 & 1 & 1) & $1]$ & 1 & 1 & 1) & 1 & \\
\hline OPX14BM3 & 1 & 1 & 1 & 1 & 1 & 1 & 1 & 1 & 1] & 1 & \\
\hline OPX15BM1 & 1 & 1 & 1 & 1 & 1 & 1 & 1 & 1 & ] & 1 & 1 \\
\hline OPX15BM2 & 1 & 1 & 1 & 1 & 1 & 1 & 1 & 1 & 1 & 1 & 1 \\
\hline OPX15BM3 & 1 & 1 & 1 & 1 & 1 & 1 & 1 & 1 & 1 & 1 & 1 \\
\hline OPX15BM4 & 1 & 1 & 1 & $1)$ & 1 & 1 & 1 & 1 & 1) & 1 & 1 \\
\hline OPX17BM1 & 1 & 1 & 1 & 1 & 1 & 1 & 1 & 1 & 1 & 1 & 1 \\
\hline OPX17BM2 & $\mathrm{I}$ & 1 & 1 & 1 & 1 & $1]$ & 1 & 1 & 1 & 1 & \\
\hline OPX17BM3 & 1 & $1]$ & 1 & 1 & 1 & 1 & 1 & 1 & 1 & 1 & \\
\hline OPX18BM1 & 1 & 1 & 1 & 1 & 1 & 1 & 1 & 1 & 1 & I) & \\
\hline OPX18BM2 & 1 & 1 & 1 & 1 & 1 & 1 & 1 & 1 & 1 & 1 & 1 \\
\hline OPX19BM1 & 1 & 1 & I) & 1 & 1 & 1 & 1 & 1 & 1 & 1 & \\
\hline OPE 14BM1 & 1 & 1 & 1 & 1 & 1 & 1 & 1 & 1 & 1 & 1) & \\
\hline OPE14BM2 & 1 & $1]$ & 1 & 1 & 1) & 1) & 1) & 1 & 1] & 1 & \\
\hline OPE14BM3 & 1 & 1 & 1 & 1 & 1 & 1 & 1 & 1 & 1 & 1 & 1 \\
\hline OPE17BM1 & 1 & 1 & 1 & 1 & 1) & $1)$ & 1 & 1 & 1 & 1 & \\
\hline OPE19BMI & 1 & 1 & 1 & 1 & 11 & 1) & 1 & 1 & 1] & 1 & \\
\hline OPE 19BM2 & 1 & 1 & 1 & 11 & 1 & 1 & 1 & 1 & 1 & 1 & \\
\hline OPE20BM1 & 1 & 1 & 1 & 1 & 1 & 1 & 1 & 1 & 1 & 1 & \\
\hline OPE20BM2 & 1 & 1 & 1 & 1 & 1 & 1 & 1 & 1 & 1 & 1 & \\
\hline OPE 20BM3 & 1 & $1]$ & 1 & $1]$ & 1 & 1 & $1]$ & 1] & 1] & 1 & \\
\hline
\end{tabular}


Anexo 1 - Presença e ausência de 156 bandas de RAPD

(Continuação)

\begin{tabular}{|c|c|c|c|c|c|c|c|c|c|c|c|}
\hline Banda & DG115 & DG116 & DG118 & DG138 & DG117 & DG119 & DG120 & DG121 & DG122 & DG123 & DG124 \\
\hline OPX09-A-01 & 0 & 0 & 0 & 0 & 0 & 0 & 0 & 0 & 0 & 0 & 0 \\
\hline OPX14-A-01 & 1 & 1 & 의 & 0 & 1 & 1 & 1 & 1 & 1 & 0 & 1 \\
\hline OPE01-A-01 & 1 & 0 & 0 & 1 & 0 & 0 & 1 & 0 & 1 & 1 & 0 \\
\hline OPE01-A-02 & 0 & I & 1 & 0 & 0 & 0 & 1 & 1 & 1 & 0 & 0 \\
\hline OPE03-A-01 & 1) & 1 & 0 & 0 & 0 & 0 & $?$ & 0 & 1) & 0 & 0 \\
\hline OPE03-A-02 & 1 & 1 & 1 & 1 & 1 & 0 & 1 & 0 & 0 & 1 & 1 \\
\hline OPE03-A-03 & 1 & 1 & 1 & 1 & 1 & 1 & 1 & 1 & 0 & 0 & 1 \\
\hline OPE05-A-01 & 1 & 0 & 1 & 1 & 1 & 1 & 1 & 1 & 1) & 0 & 1 \\
\hline OPE05-A-02 & 1 & 11 & 1 & 1 & 1 & 1 & 1 & 1 & 1 & 1 & 1 \\
\hline OPE05-A-03 & 1 & 1 & 0 & 0 & 0 & 0 & 0 & 0 & 0 & 0 & 0 \\
\hline OPE06-A-01 & 0 & 0 & 0 & 1 & 0 & 0 & 1 & 0 & 11 & $1]$ & 0 \\
\hline OPE07-A-01 & 0) & 0) & 1 & 0) & 11 & 11 & 0 & 0 & 0 & 0 & 1 \\
\hline OPE07-A-02 & 1 & 1 & 1 & 1 & 1 & 0 & ] & 0 & 1 & 1 & 0 \\
\hline OPE09-A-01 & 1 & 0 & 0 & 0 & 0 & of & 1 & a) & 0 & 0 & 0 \\
\hline OPE09-A-02 & 0 & 0 & 1 & 0 & 1 & 0 & 0 & 1 & 1 & 1 & 0 \\
\hline OPE 10-A-01 & 1 & 1 & 0 & 1) & ()) & 1 & 1 & 1 & 1 & 1 & 0 \\
\hline OPE10-A-02 & 0 & 0 & 0 & 0 & 0 & 1 & 0 & 0 & 0 & 0 & 0 \\
\hline OPE 10-A-03 & 0 & 0 & 1 & 0 & 1 & 0 & 0 & 1 & 1 & 0 & 1 \\
\hline OPE10-A-04 & 1 & 0 & 1 & 0 & 1 & 1 & 요 & 0 & 0 & 1 & 1 \\
\hline OPE11-A-01 & 1 & 1 & 1 & 1 & 1 & 1 & 1 & 1 & 0 & 0 & 0 \\
\hline OPE 11-A-02 & 1 & 1 & 0 & 1 & 0 & 0 & 1 & 1 & 1 & 1 & 0 \\
\hline OPE15-A-01 & 1 & 0 & 1 & 0 & 1 & 1 & 0 & 1 & 0 & 1 & 1 \\
\hline OPE15-A-02 & 1 & 1) & 0 & 1 & 0 & 0 & 1 & 1 & 0) & 1 & 0 \\
\hline OPE15-A-(03) & 1 & 1 & 1 & 1 & 1 & 0 & 1 & 1 & 11 & 1 & 1 \\
\hline OPE16-A-01 & 1 & 1) & 1 & 0 & 1 & 1 & 0 & 1 & 1 & 1 & 1 \\
\hline OPE16-A-02 & 1 & 0 & 0 & 1 & 0 & 0 & 1 & 0 & 1 & 0 & 0 \\
\hline OPE17-A-01 & 0 & 1 & 0 & 1 & 0 & 11 & 1 & 1 & 1 & 1 & 1 \\
\hline OPE17-A-02 & 1 & 1 & 1 & 1 & 1 & 1 & 1 & 1 & 1 & 1 & 1 \\
\hline OPE 17-A-03 & 0 & 0 & 0 & 0 & 0) & 0 & 0 & 0 & 0 & 0 & 0 \\
\hline OPE 17-A-04 & 0 & 1 & 1 & 1 & 1 & 0 & 1 & 11 & 0 & 0 & $?$ \\
\hline OPE19-A-01 & 0 & 1 & 1 & 0 & 0 & 0 & 0 & 1 & 0 & 1 & 0 \\
\hline OPE20-A-01 & 0 & 0 & 0 & 1 & 0 & 1 & 1 & 0 & 1 & 0 & 0 \\
\hline OPE20-A-02 & 1 & 1 & 1 & 1 & 1 & 1 & 1 & 1 & 1 & 1 & 1 \\
\hline OPX01-B-01 & 0 & 1 & 0 & 0 & 0 & 0 & 0 & 0 & 0 & 1 & 0 \\
\hline OPX01-B-02 & 0 & 0 & 0 & 0 & 0 & 0 & 0 & 0 & 0 & 0 & 0 \\
\hline OPX01-B-03 & 1 & 0 & 1 & 1 & 1 & 1 & 1 & 1 & 1 & 0 & 0 \\
\hline OPX01-B-04 & 0 & 1 & 1 & 1 & 1 & 1 & 1 & 1 & 1 & 1 & 1 \\
\hline OPX01-B-05 & 0 & 0 & 0 & 1 & 0 & 0 & 1 & 0 & 0 & 0 & 0 \\
\hline OPX01-B-06 & 0 & 1 & 0 & 0 & 요 & 0 & 0 & 0 & 0 & 1 & 0 \\
\hline OPX01-B-07 & 1 & 1 & 1 & 1 & 1 & 1 & 1 & 1 & 1 & 1 & 0 \\
\hline OPX01-B-08 & 1 & 0 & 0 & 1 & 0 & ] & 1 & 0 & 1 & 0 & 1 \\
\hline OPX01-B-09 & 1 & 1 & 1 & 1 & 1 & 1 & 1 & 1 & 1 & 1 & 1 \\
\hline OPX01-B-10 & 0 & 0 & 1) & 0 & 1 & 1 & 0 & 0 & 이 & 0 & 1 \\
\hline OPX03-B-01 & 1 & 1 & 1 & 1 & 0 & 1 & 1 & 1 & 1 & 0 & 0 \\
\hline OPX03-B-02 & 1 & 1 & 0 & 0 & 0 & 1 & 1 & 1 & 1 & 0 & 1 \\
\hline OPX04-B-01 & 0 & 1 & 1 & 0 & 1 & 1 & 0 & 1 & 1 & 1) & 1 \\
\hline OPX04-B-02 & 1 & 1 & 0 & 0 & 0 & 0 & 0 & 0 & 1) & 0 & 0 \\
\hline OPX05-B-01 & 1 & 1 & 0 & 1) & 0 & 0 & 1 & 0 & 0 & 1 & 0 \\
\hline OPX05-B-02 & 1 & 11 & 1 & 1 & 1 & 1 & 11 & 0 & 0 & 1 & 1 \\
\hline OPX06-B-01 & 0 & 0 & 0 & 0 & 0 & 0 & 0 & 0 & 0 & 0 & 0 \\
\hline OPX07-B-01 & 0 & 0 & 0 & 0 & 0 & 0 & 0 & 0 & 1 & 1 & 0 \\
\hline OPX08-B-01 & 0 & 1 & 0 & 0 & 0 & 0 & 0 & 0 & 0 & 1 & 0 \\
\hline
\end{tabular}


Anexo 1 - Presença e ausência de 156 bandas de RAPD

(Continuação)

\begin{tabular}{|c|c|c|c|c|c|c|c|c|c|c|c|}
\hline Banda & DG115 & DG116 & DG118 & \begin{tabular}{|l|} 
DG138 \\
\end{tabular} & DG117 & DG119 & DG120 & DG121 & DG122 & DG123 & DG124 \\
\hline OPX08-B-02 & 1) & 0 & 1 & 1 & 1 & 1 & 1 & 1 & 1 & 0 & 1 \\
\hline OPX08-B-03 & 0 & 0 & 0 & 0 & (0) & 0 & 0 & 0 & 0 & 0 & 0 \\
\hline OPX09-B-01 & 1 & 0 & 1 & 1 & 1 & 1 & 1 & 1 & 1 & 0 & 0 \\
\hline OPX11-B-01 & 0 & 0 & 0 & 0 & 0 & 0 & 0 & 0 & 0 & 0 & 0 \\
\hline OPX11-B-02 & 0 & 0 & 0 & 1 & 0 & 0 & 1 & 0 & 0 & 0 & 0 \\
\hline OPX12-B-01 & 0 & 1 & 0 & 0 & 0 & 0 & 0 & 0 & 0 & 1 & 0 \\
\hline OPX13-B-01 & 1 & 이 & 0 & 0 & of & 0 & 0 & 1] & 1 & 0 & 0 \\
\hline OPX14-B-01 & 0 & 1) & 0 & 0 & 0 & 0 & 0 & 0 & 0 & 1 & 0 \\
\hline OPX14-B-02 & 1 & 0 & 1 & 1] & 1 & 1 & 1 & 1 & 1 & 0 & 1 \\
\hline OPX16-B-01 & 1 & 1 & 1 & 1 & 1) & 1 & 1 & 1 & 1 & 1 & 1 \\
\hline OPX16-B-02 & 1 & 1 & 1 & 1 & 1] & 1 & 1) & I) & 0 & 1 & 1 \\
\hline OPX16-B-03 & 0 & 0 & 1 & 0 & 1 & II & 0 & 0 & 0 & 0 & 1 \\
\hline OPX17-B-01 & 0 & 0 & 0 & 0 & 0 & 1) & 0 & 0 & 0 & 0 & 0 \\
\hline OPX17-B-02 & 1) & 1 & 1 & 1 & 1 & 1 & 1 & ] & ] & 1 & \\
\hline OPX18-B-01 & 0 & 0 & 1 & 0 & 1) & 0 & () & 0 & 0 & 0 & 0 \\
\hline OPX19-B-01 & 1) & 0 & 0 & 1 & 0 & ] & 1 & 1 & 0 & 1 & \\
\hline OPX20-B-01 & 1 & 0 & 0 & I) & 0 & 0 & 1 & 1 & 1 & 0 & 0 \\
\hline OPE07-B-01 & 1 & 1 & 1) & 0 & 1 & 0 & 0 & 0 & 0) & 0 & \\
\hline OPE08-B-02 & 0 & 0 & 0 & 1 & 0 & 0 & 1 & 0) & $?$ & 0 & 0 \\
\hline OPE10-B-01 & 1 & 1 & 0 & 1 & 0 & ] & 1 & 1 & 1 & 1 & 1 \\
\hline OPE10-B-02 & 0 & 01 & 0 & 0 & 0 & 0 & 0 & 0 & 0 & 0 & 0 \\
\hline OPE10-B-03 & 0 & 1 & 1 & 0 & 1 & 0 & 0 & 0 & 1 & 1 & 1 \\
\hline OPE10-B-04 & 0 & 0 & 0 & 0 & 0 & 1 & 0 & 0 & 0 & 0 & 1 \\
\hline OPE11-B-01 & 1 & 0 & 1) & 1 & 1 & 1 & 1 & 1 & 1 & ? & 1 \\
\hline OPE12-B-01 & 0 & 0 & 1 & 0 & 1 & 1 & 0 & 0 & 0 & $?$ & 0 \\
\hline OPE15-B-01 & 0 & ?) & 0 & 0 & 1 & 1 & 0 & 0 & 0 & 1 & \\
\hline OPE16-B-01 & 0 & ?) & 0 & 0 & $?$ & 0 & 0 & 1 & 1 & 0 & \\
\hline OPE17-B-01 & 0 & 1 & 1 & 1 & 1 & 1 & 1 & 1 & 0 & 1] & 1 \\
\hline OPE17-B-02 & 1 & 1 & 1) & 1 & 1 & 1) & 1 & 1) & 1 & 1 & \\
\hline OPE17-B-03 & 0 & 0 & 1 & 0 & 1 & 0 & 0 & 0 & 0 & 0 & 0 \\
\hline OPE17-B-04 & 1 & 0 & 0 & 0 & 0 & 0 & 0 & 0 & 0 & 0 & 0 \\
\hline OPE19-B-01 & 1 & 1 & 1) & 1 & 1 & 1 & 1 & 1 & 1 & 1 & \\
\hline OPE19-B-02 & 0 & 0 & 0 & 0 & 0 & 0 & 0 & 0 & 0 & 0 & 0 \\
\hline OPE20-B-01 & 1) & ? & 0 & 1 & 0 & 1 & 1 & 1 & 1 & 1 & \\
\hline OPE20-B-02 & 0 & 0 & 0 & 0 & 0 & 0 & 0 & 0 & 0 & 0 & 0 \\
\hline OPE01AM1 & 1 & 1 & 1 & 1 & 1 & 1 & 1 & 1 & 1 & 1 & \\
\hline OPE01AM2 & 1 & 11 & 1) & 1 & 1 & 1 & 1 & 1 & 1 & 1 & \\
\hline OPE02AM1 & & 1 & 1] & 1 & 1 & 1 & 1] & 1 & 1) & 1 & \\
\hline OPE03AM1 & & 1 & 1 & 1 & 1] & 1 & 1 & 1 & 1 & 1) & \\
\hline OPE03AM2 & 1] & 1 & 11 & 1) & 1) & 1 & 1] & 1 & 1 & $\pi$ & \\
\hline OPE03AM3 & 1 & 1 & 1 & 1 & 1 & 1 & $1]$ & 1 & 1 & $1]$ & \\
\hline OPE03AM4 & 1 & 1 & 1 & 1 & 1 & 1 & 1 & 1 & 1 & 1 & \\
\hline OPE04AM1 & 1 & ] & 1) & 1 & 1 & 1 & 1 & 1 & 1 & 1 & \\
\hline OPE05AM1 & 1 & 1 & 1 & 1 & 1 & 1 & $1]$ & $1]$ & 1 & 1 & \\
\hline OPE07AM1 & 1 & 1 & 1 & 1 & 1 & 1 & 1 & 1 & 1 & 1 & \\
\hline OPE07AM2 & 1 & 1 & 1 & 1 & 1 & 1 & 1 & 1 & 1 & 1 & \\
\hline OPE07AM3 & 1 & 1 & 1) & 1 & 1 & 1 & 1 & 1 & 1 & 1 & \\
\hline OPE07AM4 & 1 & 1 & 1) & 1) & 1 & 1 & 1 & 1 & 1 & 1 & \\
\hline OPE10AMI & 1) & 1 & 1 & 1 & 1 & 1 & 1 & 1 & 1 & 1 & \\
\hline OPE11AMI & 1 & 1 & 1 & 1 & 1 & 1 & 1 & 1 & 1 & 1 & \\
\hline OPX01BM1 & 1 & 1 & 1 & 1 & 1 & 1 & 1 & 1 & 1 & 1 & \\
\hline OPX01BM2 & 1 & 1 & 1 & 1] & 1 & 1 & 1] & 1 & 1 & 1 & \\
\hline
\end{tabular}


Anexo 1 - Presença e ausência de 156 bandas de RAPD

(Continuação)

\begin{tabular}{|c|c|c|c|c|c|c|c|c|c|c|c|}
\hline Banda & DG115 & DG116 & DG118 & DG138 & DG117 & DG119 & DG120 & DG121 & DG122 & DG123 & DG124 \\
\hline OPX01BM3 & 1 & 1 & 1 & 1] & 1 & 1 & 1) & 1 & 1 & 1 & 1 \\
\hline OPX02BMI & 1 & 1 & 1 & 1 & 1 & 1 & 1 & 1 & 1 & 1 & 1 \\
\hline OPX02BM2 & 1 & 1 & 1 & 1 & 1) & 1 & 1 & 1 & 1 & 1 & 1 \\
\hline OPX03BM1 & 1 & $1)$ & 1 & 1 & 1 & 1 & 1 & 1 & 1 & 1 & 1 \\
\hline OPX03BM2 & 1 & 1 & 1 & 11 & 1 & 1 & 1 & 1 & 1 & 1 & 1 \\
\hline OPX03BM3 & 1 & 1 & 1 & 1 & 1 & $1)$ & 11 & 1 & 1 & 1 & 1 \\
\hline OPX03BM4 & 1 & 1 & 1 & $1)$ & 1 & 1 & 1 & 1 & 1 & 1 & 1 \\
\hline OPX04BM1 & 1 & 1 & 1 & 1 & 1 & 1 & 1 & 1 & 1 & 1 & 1 \\
\hline OPX05BM1 & 1 & 1 & 1 & 1 & 1) & $1)$ & 1 & 1 & 1 & 1 & 1 \\
\hline OPX05BM2 & 1 & 1 & 1 & 1 & 1 & 1 & 1 & 1 & 1 & 1 & 1 \\
\hline OPX06BM1 & 1 & 1 & 1 & 1 & 1 & 1 & 1 & 1 & 1 & 1 & 1 \\
\hline OPX06BM2 & 1 & 1 & 1 & 1 & 1 & 1 & 1 & 1 & 1 & 1 & 1 \\
\hline OРX06вM3 & 1 & 1 & 1 & 1 & 1 & 1 & 1 & 1 & 1 & 1 & 1 \\
\hline OPX06BM4 & 1 & 1) & 1) & 1] & 1 & 1) & 1) & 1 & 1 & 1) & 1 \\
\hline OPX07BM1 & 1 & 1 & 1 & 11 & 1 & 1 & 1 & 1 & 1 & 1 & 1 \\
\hline OPX07BM2 & 1 & 1 & 1 & 1 & 1 & 1 & 1 & 1 & 1 & 1 & I \\
\hline OPX09BM1 & 1 & 1 & 1 & 1 & 1 & 1 & 11 & 1 & 1 & 1 & 1 \\
\hline OPX10BM1 & 1 & 1 & 1 & 1 & 1 & 1 & 1 & 1 & 1 & 1 & 1 \\
\hline OPX11BM1 & 1 & 1 & 1 & 1 & 11 & 1 & 1 & 1 & 1 & 1 & \\
\hline OPX11BM2 & 1) & 1 & $1)$ & 1 & 1 & 1 & 1 & 1) & 1 & 1 & \\
\hline OPX11BM3 & 1 & 1 & 1 & 1 & 1 & 1 & 1 & 1 & 1 & 1 & \\
\hline OPX11BM4 & 1 & 1 & 1 & 1 & 1 & 1 & 1 & 1 & 1 & 1 & 1 \\
\hline OPX12BM1 & 1 & 1 & 1 & 1 & 1 & 1 & 1 & 1 & 1 & 1 & 1 \\
\hline OPX12BM2 & 1 & 1 & 1 & 1) & 1 & 1 & 1 & 1 & 1 & 1 & \\
\hline OPX12BM3 & 1 & 1 & 1 & 1 & 1 & 1 & 1 & 1 & 1 & 1 & 1 \\
\hline OPX12BM4 & 1 & 1 & 1 & 1 & 1 & 1 & 1 & 1 & 1 & 1 & 1 \\
\hline OPX12BM5 & 1 & 1 & 1 & 1) & 1 & 1 & 1 & 1 & 1 & 1 & 1 \\
\hline OPX12BM6 & 1 & 1 & $1)$ & 1 & 1 & 1 & 1 & 1 & 1 & 1 & \\
\hline OPX12BM7 & 1 & 1 & 1 & 1 & 1 & 1 & 1 & 1 & 1 & 1 & \\
\hline OPX13BM1 & 1 & 1 & 1 & 1 & 1 & 1 & 1 & 1 & 1 & 1 & 1 \\
\hline OPX14BM1 & 1 & 1 & 1 & 1 & 1 & 1 & 1 & 1 & 1 & 1 & 1 \\
\hline OPX14BM2 & 1 & 1 & 1 & 1 & 1 & 1 & $1]$ & 1 & 1 & 1 & 1 \\
\hline OPX14BM3 & $1]$ & ] & 1 & 1 & 1 & 1 & 1 & 1 & I] & 1 & 1 \\
\hline OPX15BM1 & 1 & 1] & 1 & 1 & 1 & 1 & 1 & 1 & 11 & 1 & 1 \\
\hline OPX15BM2 & 1 & 1 & 1 & 1 & 1 & 1 & 1 & 1 & 1 & 1 & \\
\hline OPX15BM3 & 1 & 1 & 1 & 1 & 1 & 1 & 1 & 11 & 1 & 1 & 1 \\
\hline OPX15BM4 & 1 & 1 & 1 & 1 & 1) & 1 & 1 & 11 & 1 & 1 & \\
\hline OPX17BM1 & 1 & 1 & 1 & 1) & 1 & 1 & 1 & 1) & 1) & 1 & \\
\hline OPX17BM2 & 1 & 1 & 1 & 1 & 1 & 1 & 11 & 1 & 1 & 1 & \\
\hline OPX17BM3 & 1] & 1] & 1 & 1 & 1 & 1 & 1 & 1 & 1 & 1 & \\
\hline OPX18BMI & 1 & 1 & 1 & 1 & 1 & 1 & 1 & 1 & 1 & 1 & \\
\hline OPX18BM2 & 1 & 1 & 1 & 1 & 1 & 1 & 1 & 1 & 1 & 1 & \\
\hline OPX19BM1 & 1 & ] & 1 & 1 & 1 & 1 & 1 & 1 & 1 & 1 & \\
\hline OPE14BMI & 1 & 1 & 1 & 1 & 1 & 1 & 1 & 1 & 1 & 1 & \\
\hline OPE14BM2 & 1 & 1 & 1 & 1 & 1 & 1 & 1 & 1 & 1 & 1 & \\
\hline OPE14BM3 & 1 & 1 & 1 & 1 & 1 & 1 & 1 & 1 & 1 & 1 & \\
\hline OPE17BM1 & 1 & 1 & 1 & 1 & 1 & 1 & 1 & 1 & 1 & 1 & \\
\hline OPE19BM1 & 1 & 1 & 1 & 1 & 1 & 1 & 1 & 1 & 1 & 1 & \\
\hline OPE19BM2 & 1 & 1 & 1 & 1 & 1 & 1 & 1 & 1 & 1 & 1 & \\
\hline OPE20BM1 & 1 & 1 & 1 & 1 & 1 & 1 & 1 & 1 & 1 & 1 & 1 \\
\hline OPE20BM2 & 1 & 1 & 1 & 1 & 1 & 1 & 1 & 1 & 1 & 1 & \\
\hline OPE20BM3 & 1 & I & 1 & 1 & 1 & 1 & ] & 1 & 1 & 1) & 1 \\
\hline
\end{tabular}


Anexo 1 - Presença e ausência de 156 bandas de RAPD

(Continuação)

\begin{tabular}{|c|c|c|c|c|c|c|c|c|c|c|c|}
\hline Banda & DG125 & DG126 & DG127 & DG128 & DG129 & DG130 & DG131 & DG132 & DG133 & DG134 & DG137 \\
\hline OPX09-A-01 & 0 & 1) & 0 & 0 & 0 & 0 & 0 & of & 0 & 0 & 0 \\
\hline OPX14-A-01 & 1 & 01 & 1 & 1 & of & 0 & 1 & 11 & 0 & 1 & 0 \\
\hline OPE01-A-01 & 1 & 0 & 0 & 0 & 1 & 0 & 1 & 0 & 0 & 0 & 0 \\
\hline OPE01-A-02 & 0 & of & 1 & 0 & 1 & 1 & of & 0 & 1 & 0 & of \\
\hline OPE03-A-01 & 0 & 0 & 0 & 0 & 0 & 0 & 0 & 0 & 0 & 0 & 0 \\
\hline 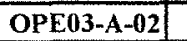 & II & 1 & 0 & 0 & 0 & 0 & 0 & 0 & 0 & 1 & 0 \\
\hline OPE03-A-03 & 0 & 0 & 0 & 1 & 0 & 0 & 1 & 0 & 1 & 1 & 1 \\
\hline OPE05-A-01 & 0 & 1 & 1 & 1 & 1 & 1 & 1) & 1 & of & 1 & 1 \\
\hline OPE05-A-02 & 11 & 1 & 11 & 1 & 1 & 1 & 1 & 1 & 0 & 1 & 1 \\
\hline OPE05-A-03 & 0 & 0 & 0 & 0 & 0 & of & 0 & 0 & 0 & 0 & 0 \\
\hline OPE06-A-01 & 1] & 0 & 0 & ? & 0 & 0 & 0 & 0 & 0 & 0 & 0 \\
\hline OPE07-A-01 & 0 & 1 & 1) & 11 & ? & 1 & 1 & 1 & $1]$ & $1]$ & 1 \\
\hline OPE07-A-02 & 0 & 1 & 1 & 0 & 可 & 1 & (0) & ] & 0 & 1 & 0 \\
\hline OPE09-A-01 & 0 & 0 & 0 & 0 & 0 & of & 0 & 0 & 0 & 1 & 0 \\
\hline OPE09-A-02 & 1) & 0 & 11 & 0 & 01 & 0 & ] & 0 & 2 & 01 & 0 \\
\hline OPE 10-A-101 & 1 & 0 & 1 & 11 & 11 & 11 & 1 & 1 & 3 & 1 & \\
\hline OPE10-A-02 & 0 & 1 & 0 & 0 & 11 & 0 & 0 & 0 & ?] & 0 & \\
\hline OPE 10-A-03 & 0 & of & 0 & of & 0 & 0 & 0 & 0 & ?) & of & 0 \\
\hline OPE 10-A-04 & 11 & 0 & 1 & 0 & 0 & 0 & 1 & 0 & ? & 0 & 0 \\
\hline OPE11-A-01 & ()) & $?$ & 1 & 1 & 1 & 1 & 0 & 1 & 1 & 1 & 1 \\
\hline OPE11-A-02 & 1 & & 1 & 1 & 1 & 1 & 1 & 1 & 1 & 0 & \\
\hline OPE15-A-01 & 1 & 2 & 0 & 0 & 0 & 0 & 0 & 0 & 0 & 1 & 1 \\
\hline OPE15-A-02 & 1) & ? & 0 & 1 & 0 & of & 1 & 0 & 0 & 0 & 0 \\
\hline OPE15-A-03 & 1 & $?$ & 1 & 1 & 1) & 1 & 1 & 1 & 0 & 1 & 1 \\
\hline OPE16-A-01 & 1 & 1] & 1 & 1 & 11 & 1 & 11 & 1 & 1 & 1 & 1 \\
\hline OPE 16-A-02 & of & ?) & 0 & 0 & 0 & 0 & 0 & 0 . & 0 & 0 & 0 \\
\hline OPE17-A-01 & 1 & 21 & 1 & 1 & 1 & 1) & 1 & 1 & 1 & 1 & 0 \\
\hline OPE17-A-02 & 1 & ? & 1 & 1 & 1 & 1) & ] & 1) & 1 & 11 & \\
\hline OPE17-A-03 & of & 7 & 0 & 11 & 0 & 0) & 1 & 0 & 0 & 0 & \\
\hline OPE:17-A-04 & 0 & $?$ & 0 & 0 & 1 & 1 & ता & 1) & 0 & 0 & \\
\hline OPE19-A-01] & 1 & $?$ & 0 & ? & 0 & 0 & (1) & o) & 0 & ? & 0 \\
\hline OPE20-A-01 & 0 & $?$ & 0 & 1 & 1 & 0 & 1 & 0 & 0 & 0 & 0 \\
\hline OPE 20-A-02 & 1 & ?. & 1 & 1 & 1 & 1 & 1 & 1 & 1 & 1) & \\
\hline OPX01-B-01 & 1 & of & 이 & 0 & 0 & 0 & 0 & of & 0 & of & \\
\hline OPX01-B-02 & 0 & 0 & 0 & 0 & 0 & 0 & 0 & 0) & 0 & 1 & 0 \\
\hline OPX01-B-03 & 0 & 1 & 1 & 1 & 1 & 1 & 1 & 11 & 1 & 0 & \\
\hline OPX01-B-04 & 1] & 1) & 1 & 0 & 1 & 1 & 1) & II & 1 & 1 & \\
\hline OPX01-B-05 & 0 & 1 & 0 & 0 & 0 & 0 & 0] & 0 & 0 & 0 & \\
\hline OPX01-B-06 & 1 & of & 0 & 0 & of & 0 & 0] & 0 & 0 & 11 & \\
\hline OPX01-B-07 & 1 & 1 & 1 & 1 & 1 & 1 & 1 & 1 & 1 & 1 & \\
\hline OPX01-B-08 & 1 & 1 & 0 & 0 & 1 & 1 & 1 & 1 & 1 & 1 & \\
\hline OPX01-B-09 & 1 & 1 & 1 & 1 & 1 & 1 & 1 & 1 & 1 & 1 & \\
\hline OPX01-B-10 & 0 & 1 & 0 & 0 & 1 & ] & 0 & 1 & 0 & 0 & \\
\hline OPX03-B-01 & 1 & 1 & 1 & 1 & 1 & 1 & 1 & I & 1 & 1 & \\
\hline OPX03-B-02 & 1 & 0 & 1) & 1 & 1 & 1 & 1 & 1 & 0 & 1 & \\
\hline OPX04-B-01 & 1) & 1 & 1 & 1] & 1 & 1 & 1 & 1 & 1 & 1 & \\
\hline OPX04-B-02 & 0 & 0 & 0 & 0 & 0 & 0 & 0 & 0 & 0 & 0 & \\
\hline OPX05-B-01 & 1 & 0 & 0 & 0 & $1)$ & 11 & 0 & 0 & 0 & 0 & \\
\hline OPX05-B-02 & 11 & 1 & 1 & 1 & 1 & 1 & $1]$ & 1 & 1 & 1 & \\
\hline OPX06-B-01 & 0 & 0 & of & of & 0 & 0 & 0 & 0 & 0 & 0 & \\
\hline OPX07-B-01 & 1 & 0 & 0 & of & 0 & 0 & 0 & of & 0 & 0 & \\
\hline OPX08-B-01] & 1] & 0 & 0 & 0 & 0 & 0 & ol & 01 & 01 & of & \\
\hline
\end{tabular}


Anexo 1 - Presença e ausência de 156 bandas de RAPD

(Continuação)

\begin{tabular}{|c|c|c|c|c|c|c|c|c|c|c|c|}
\hline Banda & DG125 & DG126 & DG127 & DG128 & DG129 & DG130 & DG131 & DG132 & DG133 & DG134 & DG137 \\
\hline OPX08-B-02 & 0 & 1 & 1 & 1) & 1) & 1 & 1 & 1 & 1 & 0 & 1 \\
\hline OPX08-B-03 & 0 & 0 & 0 & 0 & 0 & 0 & 0 & 0 & 0 & 1 & 0 \\
\hline OPX09-B-01 & 0 & 1 & 0 & 1 & 1 & 1 & 1 & 1 & 1 & 0 & 1 \\
\hline OPX11-B-01 & 0 & 0 & 0 & 0 & 0 & 0 & 0 & 0 & 0 & 0 & 0 \\
\hline OPX11-B-102 & 0 & 0 & 0 & 0 & 0 & 0 & 0 & 0 & 0 & 0 & 0 \\
\hline OPX12-B-01 & 1 & 0 & 0 & 0 & 0 & 0 & 0 & 0 & 0 & 0 & 0 \\
\hline OPX13-B-01 & 0 & 0 & 1 & 0 & 0 & 0 & 0 & 0 & 0 & 0 & 0 \\
\hline OPX14-B-01 & 1 & 0 & 0 & 0 & 0 & 0 & 0 & 0 & 0 & 1 & 0 \\
\hline OPX14-B-02 & 0 & 1) & 1 & 1 & 1 & 1 & 1) & 1 & 1) & 0 & $1)$ \\
\hline OPX16-B-01 & 1 & 1 & 1 & $1)$ & 1 & 1) & 1) & 1 & 1 & 1 & 1 \\
\hline OPX16-B-02 & 1 & 1 & 0 & 1 & 1 & 1 & 1 & 1 & 1 & 0 & 1 \\
\hline OPX16-B-03 & 0 & 1 & 0 & 0 & 1 & 1 & 0 & 1 & 0 & 1 & 1 \\
\hline OPX17-B-01 & 0 & 0 & 0 & 0 & 0 & 0 & 0 & 0 & 0 & 0 & 0 \\
\hline $\mathrm{OPX} 17-\mathrm{B}-02$ & 1 & 1 & 0 & 1 & 0 & 1 & 1 & 0 & 1 & 1 & 1 \\
\hline OPX18-B-01 & () & 0 & 1 & 0 & 1 & 1 & ()) & 1 & 0 & 1 & 1 \\
\hline OPX19-B-11 & 1 & 1 & $1)$ & 1 & 1 & 11 & 1 & 11 & 1) & 1 & 0 \\
\hline OPX20-B-01 & 1 & 0 & 0 & 1 & $?$ & 0 & 1 & 0 & a) & 1 & 1 \\
\hline OPE07-B-01 & 0 & 0 & 1 & 0 & 1 & 0 & 0 & 0 & 1 & & 0 \\
\hline OPE08-B-02 & 0 & 1 & 0 & 0 & 0 & 1 & 0 & 1 & 0 & 1 & 0 \\
\hline OPE 10-B-01 & 1) & 0 & 0 & 0 & 0 & 0 & 0 & 0 & 0 & 0 & 0 \\
\hline OPE10-B-02 & 0 & 0 & 0 & 0 & 0 & 0 & 0 & 0 & 0 & 0 & 0 \\
\hline OPE10-B-03 & 1 & 1 & 1 & 1 & 1 & 1 & 1 & 1 & 1 & 0 & 0 \\
\hline OPE10-B-04 & 0 & 1 & 1 & 1 & 1 & 1 & 1] & 1 & 1 & 1 & 1 \\
\hline OPE11-B-01 & 1 & 1 & ? & 1 & 1 & 1 & I) & 1 & 1 & 1) & 1 \\
\hline OPE12-B-01 & ?] & 0 & 0 & 0 & 0 & 0 & 0 & o) & 0 & of & \\
\hline OPE15-B-01 & 1 & 1 & 0 & 0 & 0 & 0 & 0 & 0 & 0 & 0 & 0 \\
\hline OPE16-B-01 & 요 & 0 & 0 & 0 & ?) & 0 & 0 & 0 & 0 & ? & 0 \\
\hline OPE17-B-01 & 1 & 0 & 1 & 0 & 1 & 1 & 0 & 1 & 0 & 1 & 0 \\
\hline OPE17-B-02 & 11 & 1 & 1 & 1 & 0 & 1 & 1 & 1 & 1 & 1 & 1 \\
\hline OPE17-B-03 & 0 & 0 & 1 & 0 & 1 & 0 & 0 & 0 & 0 & 1 & 0 \\
\hline OPE17-B-04 & 0 & 0 & 0 & 0 & 0 & 요 & 0 & o) & 0 & 0 & 0 \\
\hline OPE19-B-101 & 11 & 1 & 3 & 1 & 1 & 1 & 11 & 1 & 1 & 1 & 1 \\
\hline OPE19-B-02 & 0 & 0 & 0 & 1 & 0 & 0 & 1 & 0 & 0 & 0 & 0 \\
\hline OPE20-B-01 & 1 & 0 & 0 & 0 & 0 & 0 & of & 0 & 0 & 1 & 1 \\
\hline OPE 20-B-02 & 0 & 0 & 0 & 0 & 0 & 0 & 0 & 0 & 0 & 0 & 0 \\
\hline OPE01AM1 & 1 & 1 & 1 & 1 & 1 & 1 & 1 & 1 & 1 & 1 & 1 \\
\hline OPE01AM2 & 1 & 1 & 1 & 1 & 1 & 1 & 1 & 1 & 1 & $1]$ & \\
\hline OPE02AM1 & 1 & 1 & 1 & 1 & 1 & 1 & 1) & 1 & 1 & 1 & \\
\hline OPE03AM1 & 1 & 1 & 1 & 1 & 1 & 1 & 1 & 1 & 1 & 1 & \\
\hline OPE03AM2 & 1 & 1 & 1 & 1 & 1 & 1 & 1 & 1 & 1 & 1 & \\
\hline OPE03AM3 & 1 & 1 & 1 & 1 & $1]$ & 1 & 1 & 1 & 1 & 1 & 1 \\
\hline OPE03AM4 & $1]$ & 1 & 1 & 1 & $1]$ & 1 & 1 & 1 & 1 & 1) & 1 \\
\hline OPE04AM1 & 1 & 1 & 1 & 1 & 1 & 1 & 11 & 1 & 1 & 1 & \\
\hline OPE05AM1 & 1 & 1 & 1 & 1 & 1 & 1 & 1) & 1 & 1 & 1 & 1 \\
\hline OPE07AM1 & 1 & 1 & 1 & 1 & 1 & 1 & 1 & 1 & 1 & 1 & \\
\hline OPE07AM2 & 1 & 1 & 1 & 1 & 1 & 1 & 1 & 1 & 1 & 1 & \\
\hline OPE07AM3 & 1 & 1 & 1 & 1 & 1 & 1 & 1 & 1 & 1 & 1 & \\
\hline OPE07AM4 & 1 & 1 & 1 & 1 & 1 & 1 & 1 & 1 & 1 & 1 & \\
\hline OPE10AM1 & 1 & 1 & 1 & 1 & 1 & 1 & 1 & 11 & 1 & 1 & \\
\hline OPE11AM1 & 1 & 1 & 1 & 1 & 1 & 1 & 1 & 1 & 1 & 1 & \\
\hline OPX01BM1 & 1 & 1 & 1 & 1 & 1 & 1 & 1 & 1 & 1 & 1 & \\
\hline OPX01BM2 & 1 & 1 & 1 & 1 & 1 & 1 & 1 & 1 & 1 & 1 & 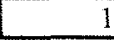 \\
\hline
\end{tabular}


Anexo 1 - Presença e ausência de 156 bandas de RAPD

(Continuação)

\begin{tabular}{|c|c|c|c|c|c|c|c|c|c|c|c|}
\hline Banda) & DG125 & DG126 & DG127 & DG128 & DG129 & DG130 & DG131 & DG132 & DG133 & DG134 & DG137 \\
\hline OPX01BM3 & 1 & 1 & 1 & 1 & 1 & 1 & 1 & 1 & 1 & 1] & 1 \\
\hline OPX02BM1 & 1 & 1 & 1 & 1 & 1 & 11 & 1 & 1 & 1 & ] & 1 \\
\hline OPX02BM2 & 1 & 1 & 1 & 1 & ] & 1 & 1 & 1 & 1 & 1 & \\
\hline OPX03BMI & 1 & 1 & 1 & $1]$ & 1 & 1 & 1 & 1 & 1 & 1 & \\
\hline OPХ03ВM2 & 1 & 1 & 1 & 1 & 1 & 1 & 1 & 1 & 1 & 1 & 11 \\
\hline OPX03BM3 & 1 & 1 & 1 & 1 & 1 & 1 & 1 & 1 & 1 & 1 & 1 \\
\hline OPX03BM4 & 1 & 1 & 1 & 1) & 1 & 1) & $1)$ & 1 & $1)$ & 1 & \\
\hline OPX04BM1 & 1) & 1 & 1 & 11 & 1 & 1 & 1 & 1 & 1 & 1 & \\
\hline OPX05BM1 & 1 & 1 & 1 & 1 & 1 & 1 & 1 & 1 & 1 & 1 & \\
\hline OPX05BM2 & 1 & 1 & 1 & 1 & 1 & 1 & 1 & 1 & 1 & 1 & \\
\hline OPX06BM1 & 1 & 1 & 1 & i) & 1 & 1 & 1 & 1 & 1 & 1 & \\
\hline OPX06BM2 & 1 & 1 & 1 & 1 & 1 & 1 & 1 & 1 & 1 & 11 & 1 \\
\hline OPX06BM3 & 1 & 1 & 1 & 1 & 1 & 1 & 1 & 1 & ]1) & 1 & 1 \\
\hline OPX06BM4 & 1 & 1 & 1 & 1 & 1 & 1 & 11 & 1 & 1 & 1 & 1 \\
\hline OPX07BM1] & 1 & 1 & 1 & 1 & 1) & ] & 1 & 1 & 1] & I) & 1 \\
\hline OPX07BM2 & 1. & 1 & 1) & 1 & 1 & 1 & $1)$ & 1 & 1 & 1) & 1 \\
\hline OPX09BM1 & 1 & 1 & 11 & 1 & 1] & 11 & 1 & 1 & 1 & 1 & 11 \\
\hline OPX10BM1 & 1] & 7 & 1] & 1 & 1 & 1 & $1]$ & 1 & 1 & 1 & 1 \\
\hline OPX11BM1 & 1 & 1 & 1 & 1 & 1 & 1 & 1 & 1 & 1 & $1]$ & 1 \\
\hline OPX11BM2 & 1 & 1 & 1 & 1 & 1 & 1 & 1 & 1 & 1 & 1) & 1 \\
\hline OPX11BM3 & 1 & 1 & 1 & 1 & 1 & 1 & 1 & 1 & 1 & 1 & 1 \\
\hline OPX11BM4 & 1 & 1 & 1 & 1 & 11 & 1 & 11 & 1 & 1 & 1 & 1 \\
\hline OPX12BM1 & 1 & 1 & 1 & 1 & 1 & 1 & 1 & 1 & 1 & 1 & 1 \\
\hline OPX12BM2 & 1 & 1 & 1 & 11 & 1 & 1 & 1 & 1 & 1 & 1 & 1 \\
\hline OPX12BM3 & 1 & 1 & 1) & 1 & 1 & 1 & 1 & 1 & 1 & 1 & 1 \\
\hline OPX12BM4 & 1 & 1 & 1 & 1 & 1 & 1 & 1 & 1 & 1 & 1 & \\
\hline OPX12BM5 & 1 & 1 & 1 & 1 & 1 & 1 & 1 & 1 & 14 & 1 & \\
\hline OPX12BM6 & 1 & ] & 1 & 1 & 1 & 1 & 1 & 1 & 1 & 1 & \\
\hline OPX12BM7 & 1 & 1 & 1 & 1 & 1 & 1 & 1 & 1 & 1 & 1 & \\
\hline OPX13BMI & 1 & 1 & 1 & 1 & 1 & 1 & 1 & 1 & 1 & 1 & \\
\hline OPX14BM1 & 1] & $1]$ & 1 & 1] & 1) & 11 & 1) & 1) & 1 & 1 & 1 \\
\hline OPX14BM2 & 1 & 1 & 1 & 1 & 1) & 11 & 1 & 1 & 1 & 1 & 1 \\
\hline OPX14BM3 & 1) & 1 & 1 & I) & 1) & 11 & 1 & 1) & 1 & 1 & 1 \\
\hline OPX15BM1 & 1] & 11 & 1 & 1 & 1 & 1 & 1 & 11 & 1 & 1 & 1 \\
\hline OPX15BM2 & 1 & 1 & 1 & 1 & 1 & 1 & 1 & 1) & 1 & 1 & 1 \\
\hline OPX15BM3 & 1 & 1 & 1 & 1 & 1 & 1 & 1 & 1 & 1 & 1 & 1 \\
\hline OPX15BM4 & 1 & 1 & 1 & 1 & 1 & 1 & 1 & 1 & 1 & $1]$ & 1 \\
\hline OPX17BM1 & 1 & $1]$ & 1 & $1)$ & 1 & $1)$ & 1 & 1 & 1 & 1 & 1 \\
\hline OPX17BM2 & 1 & 1 & 1 & 1 & 1. & 1 & 1 & 1 & I) & 1 & 1 \\
\hline OPX17BM3 & 1 & 1 & 1 & 1 & 1 & 1) & 1 & $1]$ & 1 & 1 & \\
\hline OPX18BM1 & 1 & 1 & 1 & 1 & 1 & 1 & 1 & 1 & 1 & 1 & \\
\hline OPX18BM2 & 1 & 1 & 1 & 1 & 1 & 1 & 1 & 1 & 1 & 1 & \\
\hline OPX19BM1 & 1 & 1 & 1 & 1 & 1 & 1 & 1 & 1 & 1 & 1 & \\
\hline OPE14BM1 & 1 & 1 & 1 & 1 & 1 & 1 & 1 & 1 & 1 & 1 & \\
\hline OPE14BM2 & 1 & 1 & 1 & 1) & 1 & 1 & 1) & I) & 1 & 1) & \\
\hline OPE14BM3 & 1 & 1 & 1 & 1 & 1 & 1 & 1 & 1 & 1 & 1 & \\
\hline OPE17BM1 & 1 & 1 & 1 & 1 & 1 & 1 & 1 & 1 & 1 & 1 & \\
\hline OPE19BM1 & 1 & 1 & 1 & 1 & 1 & 1 & 1 & 1 & 1 & 1 & 1 \\
\hline OPE 19BM2 & 1 & 1 & 1 & 1 & 1 & 1 & 1 & 1 & 1 & 1 & 1 \\
\hline OPE20BM1 & 1 & 1 & 1 & 1 & 1 & 1 & 1 & 1 & 1 & 1 & 1 \\
\hline OPE20BM2 & 1 & 1 & 1 & 1 & 1 & 1 & 1 & 1 & 1 & 11 & \\
\hline OPE20BM3 & e & $1]$ & I] & 1 & 1 & 1 & 1 & 1 & 1 & 1 & . \\
\hline
\end{tabular}


Anexo 2 - Presença e ausência de 134 bandas de AFLP

\begin{tabular}{|c|c|c|c|c|c|c|c|c|c|c|c|}
\hline Banda & DG038 & DG039 & DG040 & DG041 & $\mid \mathrm{DG} 042$ & DG043 & DGQ44 & DG045 & DG046 & DG047 & DG048 \\
\hline $\mathrm{ACA} / \mathrm{CAG}-051$ & 0 & 0 & 1 & 0 & 0 & 0 & 0 & 1 & 0 & 1 & 0 \\
\hline $\mathrm{ACA} / \mathrm{CAG}-052$ & 0 & 0 & 0 & 0 & 0 & 0 & 0 & 0 & 0 & 0 & 0 \\
\hline $\mathrm{ACA} / \mathrm{CAG}-056$ & 1 & 1 & 1 & 1 & 1 & 1 & 1 & 1 & 1 & 1 & 1 \\
\hline $\mathrm{ACA} / \mathrm{CAG}-058$ & 0 & 0 & 0 & 0 & 0 & 1 & 0 & 0 & 0 & 0 & 1 \\
\hline $\mathrm{ACA} / \mathrm{CAG}-060$ & 1 & 1 & 1 & 1 & 1 & 1 & 1) & 1 & 1 & 1 & 1 \\
\hline $\mathrm{ACA} / \mathrm{CAG}-063$ & 1 & 1 & 1 & 1 & 1 & 1) & 1 & 1) & 1 & 0 & 1 \\
\hline $\mathrm{ACA} / \mathrm{CAG}-066$ & $1)$ & 1 & 1 & 1 & 0 & 1) & 1 & 1 & ]) & 1) & 0 \\
\hline ACA/CAG-069 & 1 & 1 & 1 & 1 & 1 & 1 & 1) & 1 & 1 & 1 & 11 \\
\hline ACA/CAG-071 & 1) & 1 & 1 & 1 & 0 & 1 & 1) & 1] & 1 & 1 & 1 \\
\hline ACA/CAG-074 & 1 & 1 & 1 & 1 & 1 & 1 & 1 & 1 & 1 & 1 & 1 \\
\hline ACA/CAG-075 & 1) & 1 & 1 & 1] & 1 & $1]$ & 1] & 1 & 1 & 1] & 1 \\
\hline ACA/CAG-079 & 1 & 1 & 1 & 1 & 1 & 1 & 1 & 1) & 0 & 1 & 0 \\
\hline ACA/CAG-082 & 1 & 1 & 1 & 1 & 1] & 1 & 1 & 1 & I & 1 & 1 \\
\hline ACA/CAG- -085 & 1 & 1 & 1 & 1 & 1. & 1 & 1) & 1 & 1. & 1 & 1 \\
\hline ACA/CAG-089 & 1 & 1 & 1 & 0 & 1) & 1 & 요 & 1 & 1 & 0 & 0 \\
\hline ACA/CAG-094 & 1) & 1 & 1 & 1 & 1 & 1 & 1) & 1 & 1 & 1] & 1 \\
\hline ACA/CAG-095 & 1 & 0 & 1 & 1 & 0 & ] & 1 & 1 & 1 & 0 & 1 \\
\hline ACA/CAG-110 & 1 & 1 & 1 & 1 & 1 & 1 & 1) & 1 & 1) & 1 & 1 \\
\hline ACA/CAG-113 & 1 & 1 & 1 & 1 & 1 & 1 & 1 & 1 & 1 & 1 & I \\
\hline $\mathrm{ACA} / \mathrm{CAG}-143$ & 1 & 1 & 0 & 0 & 1 & 1 & 0 & 0 & of & 1 & I \\
\hline ACA/CAG-156 & 0 & 0 & 0 & 0 & 1 & 1 & 1 & 0 & 0 & 0 & 1 \\
\hline ACA/CAG-159 & 1 & 1 & 1 & 1 & 1 & 1 & 0 & 0 & 0 & 1 & 1 \\
\hline ACA/CAG-187 & 1) & 1 & 1 & 1 & 1 & 1 & 1 & 1) & 1) & 1 & 1 \\
\hline ACA/CAG-190 & 1 & 1 & 1 & 1 & 1 & 1 & ] & 1 & 1 & 1 & 1 \\
\hline ACA/CAG-206 & 1 & 1 & 1 & 1 & 0 & 1 & 1 & 0 & 0 & 1 & 1 \\
\hline ACA/CAG-211 & 1 & 1 & 1 & 1 & 1 & 1 & 1 & 1 & 1 & 1 & 1 \\
\hline ACA/CAG-250 & 1 & 1 & 1 & 1 & 1 & 1 & 1 & 1 & 1 & 1 & 1 \\
\hline \begin{tabular}{|l|l|} 
ACA/CAG-274 \\
\end{tabular} & 1 & 1 & 0 & 0 & 0 & 0 & 1 & 0 & 0 & 1 & 1 \\
\hline ACA/CAG-286 & 1 & 1 & 1] & 1 & 1 & $1]$ & 1) & 1 & 1] & 1 & 1 \\
\hline ACA/CAG-295 & 1) & 1 & 1 & 1 & 1 & 1 & 1 & 1] & (1) & 1 & 1 \\
\hline ACA/CAG-301 & 1 & 1 & 1 & 1 & 1 & 1 & 1 & 1) & 1) & 1 & 1 \\
\hline ACA/CAG-304 & 1 & 1 & 1 & 1 & 1 & 1 & 1. & 0 & 1 & 7 & 1 \\
\hline ACA/CAG-331 & 0 & 1 & 1 & 1 & 1 & 0 & 0 & 0 & 0 & 1 & 1 \\
\hline ACA/CTC-058 & 1) & 1 & 1 & 1 & 1 & 1 & 1 & 1 & 1 & 1 & 1 \\
\hline ACA/CTC-063 & 0 & 1 & 0 & 0 & 1 & 0 & 0 & 0 & 0 & 0 & 0 \\
\hline ACA/CTC-065 & 1 & 1 & 1 & 0 & 1 & 1 & 1 & 1 & 1 & 0 & 1 \\
\hline ACA/CTC-1667 & 0 & 0 & 0 & 0 & 0 & 0 & 0 & 0 & 0 & 0 & 0 \\
\hline ACA/CTC- -10 & I] & 1 & 1 & 0 & 1 & 1 & I) & 1 & 1 & 1 & 1 \\
\hline ACA/CTC-076 & 0 & 0 & 0 & 0 & of & 0 & 1] & 0 & 1 & 0 & 0 \\
\hline ACA/CTC-098 & 0 & 0 & 0 & 0 & 0 & 0 & 0 & 0 & 0 & 1 & 0 \\
\hline ACA/CTC-100 & 1 & 1 & 1 & 0 & 1 & 0 & 1 & 1) & 1 & 1 & 1 \\
\hline ACA/CTC-102 & 1 & 1 & 1 & 1 & 1 & 1 & 1 & 1 & 1 & 1 & 1 \\
\hline ACA/CTC-106 & 1 & 0 & 1 & 0 & 1 & 1 & 1 & 1 & 1 & 1 & 1 \\
\hline ACA/CTC-107 & 1 & 0 & 0 & 0 & 0 & 0 & 1 & 1 & 0 & 1 & 0 \\
\hline ACA/CTC-112 & 1 & 1 & 1 & 1 & 1 & 0 & 0 & 1 & 0 & 1 & 1 \\
\hline ACA/CTC-113 & 1 & 1 & 0 & 0 & 0 & 0 & $1]$ & 0 & 0 & 1 & 0 \\
\hline ACA/CTC-115 & 1) & 1 & 1 & 1 & ]) & 1 & 1 & 1 & 1 & 1 & 1 \\
\hline ACA/CTC-116 & 0 & 1 & 1 & 1 & 1 & 1 & 0 & 1 & 0 & 1 & 1 \\
\hline ACA/CTC-133 & 1 & 1 & 1 & 1 & 1 & 1 & 1 & 1 & 1 & 1 & $\mathrm{l}$ \\
\hline ACA/CTC-140 & 1 & 1 & 1 & 0 & 1 & 1 & 1 & 1 & 1 & 1 & 1 \\
\hline ACA/CTC-156 & 0 & 1 & 0 & 0 & 0 & 0 & 0 & 0 & 0 & 0 & 0 \\
\hline ACA/CTC-164 & 0 & 1 & 1 & 0 & 0 & 0 & 0 & 1 & 0 & 0 & 1 \\
\hline
\end{tabular}


Anexo 2 - Presença e ausência de 134 bandas de AFLP

(Continuaçãa)

\begin{tabular}{|c|c|c|c|c|c|c|c|c|c|c|c|}
\hline Banda & DG038 & DG039 & DGA40 & DG0.41 & DG042 & $\mathrm{DG} 043$ & DG044 & DG045 & DG046 & DG047 & DG048 \\
\hline ACA/CTC-171 & 0 & 0 & 0 & 0 & 0 & 1 & 0 & 1 & 0 & 1 & 0 \\
\hline $\mathrm{ACA} / \mathrm{CTC}-187$ & 1 & 0 & $1)$ & 0 & 1 & 1 & 0 & 0 & 1 & 1 & 0 \\
\hline ACA/CTC-192 & 1 & 1 & 1 & 1 & 11 & 1 & 1 & 1 & 1 & 1 & 1 \\
\hline $\mathrm{ACA} / \mathrm{CTC}-201$ & 1 & 1 & 1 & 1 & 1 & 1 & 1 & 1 & 1 & 1 & 1 \\
\hline $\mathrm{ACA} / \mathrm{CTC}-210$ & 1 & 1 & $1)$ & 1 & $1)$ & 1 & 1 & 0 & 1 & 1 & 1 \\
\hline $\mathrm{ACA} / \mathrm{CTC}-212$ & 0 & 0 & 1 & 1 & 0) & 0 & 0 & 0 & 0 & 0 & 0 \\
\hline ACA/CTC-226 & 0 & 0 & 0 & 0 & 0 & 0 & 요 & 0 & 1 & 0 & 0 \\
\hline $\mathrm{ACA} / \mathrm{CTC}-227$ & 0 & 0 & 0 & 0 & 0 & 0 & 0) & 1 & 0 & 0 & 0 \\
\hline $\mathrm{ACA} / \mathrm{CTC}-230$ & 0 & 0 & 0 & 0 & 1 & 0 & 0 & 1 & 0 & 0 & 0 \\
\hline $\mathrm{ACA} / \mathrm{CTC}-244$ & 1 & 0 & 1 & 1 & 0 & 0 & 1 & 0 & 0 & 0 & 0 \\
\hline $\mathrm{ACA} / \mathrm{CTC}-269$ & 1 & 0 & 1 & 1 & 1 & 1 & 1 & 11 & 1 & 1 & 1 \\
\hline $\mathrm{ACA} / \mathrm{CTC}-270$ & 1 & 0 & 1 & 1 & 1 & 1 & 1 & 1 & 1 & 1 & 1 \\
\hline $\mathrm{ACA} / \mathrm{CTC}-287$ & 1 & 1 & 11 & 1 & $1)$ & 1 & 11 & 1 & 1 & 1 & 1 \\
\hline $\mathrm{ACA} / \mathrm{CTC}-293$ & 11 & 0 & 1 & 0 & 1 & 14 & 1 & 0 & 0 & 0 & 0 \\
\hline $\mathrm{ACA} / \mathrm{CTC}-296$ & 1 & 1 & 1 & 1 & 0 & I) & 1 & 1 & 1 & 1) & 0 \\
\hline $\mathrm{ACA} / \mathrm{CTC}-309$ & 0 & 0 & $1)$ & 1 & 0 & 0) & 0 & (0) & 1 & 0 & 1 \\
\hline $\mathrm{ACA} / \mathrm{CTC}-322$ & 1 & 1 & 1 & 0 & 1 & 1 & 1 & 1 & 11 & 1 & 1 \\
\hline $\mathrm{ACT} / \mathrm{CAC}-062$ & 1 & 1 & 1 & 1 & 1 & 1 & 1 & 1 & 11 & 1 & 1 \\
\hline $\mathrm{ACT} / \mathrm{CAC}-064$ & 0 & 0 & 0 & 0 & 0 & 0 & 0 & 0 & 0 & 0 & 0 \\
\hline $\mathrm{ACT} / \mathrm{CAC}-081$ & 0 & 1 & 0 & 0 & 0 & of & 0 & 1 & 0 & 0 & 0 \\
\hline $\mathrm{ACT} / \mathrm{CAC}-084$ & 1 & 1 & 1 & 1 & 1 & 1 & 1 & 1 & 11 & 1 & 1 \\
\hline $\mathrm{ACT} / \mathrm{CAC}-089$ & 0 & 1 & 0 & 0 & 0 & 0 & 0 & 0 & 0 & 0 & 0 \\
\hline ACT/CAC-091 & 1 & 0 & 0 & 0 & 1 & 1 & 0 & 1 & 1 & 1 & 1 \\
\hline $\mathrm{ACT} / \mathrm{CAC}-108$ & 0 & 1 & 1 & 0 & 0 & 0 & 0 & 0 & 0 & 0 & 0 \\
\hline ACT/CAC-110 & 1 & 1 & 1 & 1 & 0 & 1 & 1 & 1 & 1 & 1 & 0 \\
\hline ACT/CAC-116 & 1 & 0 & 1 & 1 & 0 & 0 & 1 & 0 & 1 & 1 & 0 \\
\hline $\mathrm{ACT} / \mathrm{CAC}-118$ & 0 & 0 & 11 & 11 & 요 & 1 & 1 & 0 & 1 & 0 & 0 \\
\hline ACT/CAC-120 & 11 & 11 & I & 1 & 1 & 1 & 1 & 1 & 1 & 1 & 1 \\
\hline $\mathrm{ACT} / \mathrm{CAC}-124$ & 1 & 0 & 0 & 0 & 0 & 1 & 1 & 11 & 1 & 0 & 0 \\
\hline $\mathrm{ACT} / \mathrm{CAC}-127$ & 0 & 1 & 0 & 0 & 0 & 0 & 0 & 0 & 0 & 0 & 0 \\
\hline $\mathrm{ACT} / \mathrm{CAC}-140$ & 1 & 0 & 1 & 1 & 1 & 11 & 1 & 0 & 1 & 1 & 1 \\
\hline $\mathrm{ACT} / \mathrm{CAC}-143$ & 0 & 0 & 0 & 0 & 0 & 1 & 0 & 0 & 1 & 1 & 0 \\
\hline ACT/CAC-164 & 0 & 1 & 1 & 1 & 1 & 1 & 1 & 1 & 1 & 1 & 1 \\
\hline $\mathrm{ACT} / \mathrm{CAC}-167$ & 1 & 1 & 1 & 1 & 1 & 1 & 14 & 1 & 11 & $1)$ & 1 \\
\hline ACT/CAC-175 & 요 & 1 & 1 & 1 & of & 1 & 1 & 1 & 0 & 1 & 0 \\
\hline $\mathrm{ACT} / \mathrm{CAC}-188$ & 0 & 0 & 0 & 0 & 0 & 0 & 1 & 0 & 0 & 0 & 0 \\
\hline ACT/CAC-189 & 요 & 1 & 1 & 11 & 1 & 11 & 1 & 1 & 1 & 0 & 1 \\
\hline $\mathrm{ACT} / \mathrm{CAC}-201$ & 1 & 0 & 0 & 0 & 1 & 1 & 0 & 0 & 0 & 0 & 0 \\
\hline ACT/CAC-214 & 11 & of & 1 & 1 & 1 & 0 & 0 & 0 & 1 & 1 & 0 \\
\hline $\mathrm{ACT} / \mathrm{CAC}-226$ & 1 & 요 & 1 & 1 & 1 & 1 & 1 & 1 & 1 & 0 & 1 \\
\hline $\mathrm{ACT} / \mathrm{CAC}-230$ & 0 & 11 & 0 & 0 & 0 & 1 & 1 & 0 & 0 & 1 & 1 \\
\hline $\mathrm{ACT} / \mathrm{CAC}-234$ & 1 & 1 & 1 & 1 & 1 & 1 & 1 & 1 & 1 & 1 & 1 \\
\hline ACT/CAC-276 & 1 & 14 & 11 & 11 & 1 & 1 & 1 & 1 & 1 & 1 & 1 \\
\hline $\mathrm{ACT} / \mathrm{CAC}-310$ & 1 & 1 & 1 & 1 & 1 & 1 & 1 & 1 & 1 & 1 & 1 \\
\hline $\mathrm{ACT} / \mathrm{CAC}-340$ & 0 & 0 & 0 & 0 & 0 & 0 & 0 & 0 & of & 0 & 0 \\
\hline AGG/CAA-054 & 1 & 0 & 1 & 1 & 1 & 1 & 1 & 1 & 1 & 1 & 1 \\
\hline AGG/CAA-056 & 0 & 1 & 0 & 0 & 0 & 0 & 1 & 0 & 0 & 0 & 0 \\
\hline AGG/CAA-057 & 1 & 1 & 0 & 0 & 1 & 1 & 요 & 0 & 1 & 1 & 1 \\
\hline AGG/CAA-060 & $1]$ & 1 & 1 & 1 & 1 & 1 & 1 & 1 & 1 & 1 & 1 \\
\hline AGG/CAA-065 & 0 & 0 & 0) & 0 & 0 & 0 & 0 & 0 & 1 & 0 & 0 \\
\hline AGG/CAA-070 & 11 & 1 & 1 & 1 & 1 & 1 & 1 & 14 & 1 & 1 & 1 \\
\hline AGG/CAA-071 & 1 & 0 & 1 & 1 & 11 & 0 & 11 & 0 & 0 & 01 & 1 \\
\hline
\end{tabular}


Anexo 2 - Presença e ausêneia de 134 bandas de AFLP

(Continuạ̧ão)

\begin{tabular}{|c|c|c|c|c|c|c|c|c|c|c|c|}
\hline Banda & DG038 & DG039 & DG040 & DG041 & DG042 & DG043 & DG044 & DG045 & DG046 & DG047 & DG048 \\
\hline AGG/CAA-072 & 1 & 1 & 1 & 1 & 1 & 1 & 1 & 1 & 1 & 1 & 1 \\
\hline AGG/CAA-075 & 1 & 1 & 1 & 1 & 1 & 1 & 1 & 1 & 1 & 1 & 1 \\
\hline AGG/CAA-078 & 1 & 1 & 1 & 1 & 1 & 1 & 1 & 1 & 11 & 1 & 1 \\
\hline AGG/CAA-079 & 1 & 0 & 1 & 0 & 1 & 1 & 1 & 0 & 1 & 0 & 1 \\
\hline AGG/CAA-080 & 1 & 1 & 1 & 1 & 1 & ] & 1 & 1 & 1 & 1 & 1 \\
\hline AGG/CAA-1083 & 0 & 0 & 1 & 0 & 0 & 1 & 0 & (1) & 0 & 0 & 0 \\
\hline AGG/CAA-093 & 1 & 1 & 1 & 1 & 1 & 1 & 1 & 1) & 1 & 1 & 1 \\
\hline AGG/CAA-103 & 1 & 1 & 1. & 1 & 1 & 1 & 1 & 1 & 1 & 1 & 1 \\
\hline AGG/CAA-109 & 0 & 0 & 0 & 0 & 0 & 0 & 0 & 0 & 0 & 0 & 0 \\
\hline AGG/CAA-125 & 1 & 1 & 1 & 1 & 1 & 1 & 1 & 1 & 1 & 1 & 1 \\
\hline AGG/CAA-131 & 1 & 0 & 1 & 0 & 0 & 0 & 0 & 0 & 0 & 0 & 0 \\
\hline AGG/CAA-134 & 0 & 1 & 1 & 0 & 1 & 1 & 1 & 1 & 1 & 1 & 1 \\
\hline AGG/CAA-141 & 0 & 0 & 1 & 0 & 0 & 0 & 1 & 0 & 1 & 1 & 0 \\
\hline AGG/CAA-142 & 0 & 0 & 0 & 0 & 0 & 0 & 0 & 0 & 0 & 0 & 0 \\
\hline AGG/CAA-146 & 1 & 1 & 1 & 1) & 1 & 1 & 1 & 1 & 1 & 1) & I \\
\hline AGG/CAA-149 & 1 & 1 & 1 & 1 & 1 & 1 & 1 & 1 & 1 & 1 & 1 \\
\hline $\mathrm{AGG} / \mathrm{CAA}-152$ & 1 & 1 & 1 & 1 & 1 & 1 & 1 & 1 & 11 & 1 & 1 \\
\hline AGG/CAA-163 & 0 & 0 & 0 & 0 & 0 & 0 & 0 & 0 & 0 & 0 & 0 \\
\hline AGG/CAA-173 & 1 & 1 & 1 & 1 & 1 & 1 & 1 & 1 & 1 & 1 & 1 \\
\hline AGG/CAA-181 & 1 & 0 & 1 & 1 & 1 & 1 & 1 & 1 & 1 & 0 & 0 \\
\hline AGG/CAA-203 & 1 & 1 & 1 & 1 & 1 & 1 & 1 & 1 & 1 & 1 & 1 \\
\hline AGG/CAA-205 & 0 & 0 & 0 & 0 & 0 & 0 & 0 & 0 & 0 & 0 & 0 \\
\hline AGG/CAA-209 & 1 & 0 & 1 & 0 & 1 & 1 & 1 & 1 & 0 & 1 & 0 \\
\hline AGG/CAA-210 & 1 & 1 & 1 & 1 & 1) & 1 & 1 & 1 & 1 & 1 & 1 \\
\hline AGG/CAA-216 & 0 & 1 & 0 & 0 & 0 & 1 & 0 & 0 & 0 & 1 & 0 \\
\hline AGG/CAA-265 & 0 & 0 & 0 & 1 & 0 & 0 & 0 & 11 & 1 & 0 & 1 \\
\hline AGG/CAA-285 & 1 & 1 & 1 & 1 & 1 & 1 & 11 & 1 & 1 & 1 & 1 \\
\hline AGG/CAA-315 & 0 & 0 & 1 & 0 & 1 & 0 & 0 & 0 & 1 & 1 & 0 \\
\hline AGG/CAA-327 & 1 & 1 & 1 & 1 & 1 & 1 & 1 & 1 & 1 & $\mathrm{I}$ & 1 \\
\hline AGG/CAA-347 & 1 & 1 & 1 & 1 & 1 & 1 & 1 & 1 & 1 & 1 & 1 \\
\hline
\end{tabular}


Anexo 2 - Presença e ausência de 134 bandas de AFLP

(Continuacão)

\begin{tabular}{|c|c|c|c|c|c|c|c|c|c|c|c|}
\hline Banda & DG049 & DG050 & DG051 & DG052 & DG054 & DG055 & DG056 & DG058 & DG059 & DG060 & DG061 \\
\hline $\mathrm{ACA} / \mathrm{CAG}-151$ & 1 & 0 & 1 & 0 & 0 & 0 & 0 & 0 & 0 & 0 & 1 \\
\hline ACA/CAG-052 & 0 & 0 & 0 & 1 & 0 & 0 & 1 & 1 & 0 & 0 & 0 \\
\hline $\mathrm{ACA} / \mathrm{CAG}-056$ & 1 & 1 & 1 & 1 & 1 & $1)$ & 1 & 1 & 1 & 1 & 1 \\
\hline $\mathrm{ACA} / \mathrm{CAG}-058$ & 0 & 0 & 1 & 0 & 0 & of & 0 & 1 & 0 & 0 & 0 \\
\hline $\mathrm{ACA} / \mathrm{CAG}-060$ & 1 & 1 & 1 & 1) & 1 & 1 & 1 & 1 & 1 & 1 & 1 \\
\hline $\mathrm{ACA} / \mathrm{CAG}-063$ & 1 & 1 & 1 & 1 & 1 & I) & 1 & 1 & 1 & 11 & ] \\
\hline $\mathrm{ACA} / \mathrm{CAG}-066$ & 1 & 1 & 1 & 1 & 1 & I) & 0 & 1 & 1 & $1)$ & 1 \\
\hline $\mathrm{ACA} / \mathrm{CAG}-069$ & 1 & 1 & 1 & 1 & 1 & 11 & 1 & 1 & 1 & 1 & 1 \\
\hline $\mathrm{ACA} / \mathrm{CAG}-071$ & 11 & 1 & 1 & 1 & 1 & 1 & 1 & 1 & 11 & 1 & 1 \\
\hline $\mathrm{ACA} / \mathrm{CAG}-074$ & 11 & 1 & 11 & 1 & 1 & 1 & 1 & 1 & 1 & 1 & 1 \\
\hline ACA/CAG-075 & 1 & 1 & 1 & 1 & 1 & 1 & 1 & 1 & 11 & 1 & 1 \\
\hline $\mathrm{ACA} / \mathrm{CAG}-079$ & 0 & 0 & 1 & 1 & 1 & 1 & 0 & 1 & 0 & 0 & 1 \\
\hline $\mathrm{ACA} / \mathrm{CAG}-082$ & 1 & 1 & 1 & 1 & 1 & 1 & 1 & 1 & 1 & 1 & 1 \\
\hline $\mathrm{ACA} / \mathrm{CAG}-085$ & 1 & 1 & 1 & 11 & 1 & 1 & 1 & 1 & 1 & 1 & 1 \\
\hline ACA/CAG-089 & 1 & 1 & $1)$ & 0 & 0 & 1 & 0 & 1 & 11 & 1 & 1 \\
\hline $\mathrm{ACA} / \mathrm{CAG}-094$ & 1 & 1 & 1 & 1 & 1 & 1 & 1 & 0 & 1 & 1 & 1 \\
\hline $\mathrm{ACA} / \mathrm{CAG}-095$ & 1 & 1 & 1 & 0 & 1 & 1 & 1 & 1 & 1 & 1 & 1 \\
\hline ACA/CAG-110 & 1 & 1 & 1 & 1 & 1 & 1 & 1 & 1 & 1 & 1 & 1 \\
\hline ACA/CAG-113 & 1 & 1 & 1 & 1 & 1 & 1 & 1 & 1 & 1 & 1 & 1 \\
\hline $\mathrm{ACA} / \mathrm{CAG}-143$ & 1 & ()) & 1 & 0 & 1 & 11 & 1 & 1 & 1 & 0 & 1 \\
\hline $\mathrm{ACA} / \mathrm{CAG}-156$ & 1 & 0 & 1 & 0 & 0 & 0 & 1 & 0 & 1 & 0 & 0 \\
\hline $\mathrm{ACA} / \mathrm{CAG}-159$ & 1 & 1 & 1 & 1 & 1 & 1 & 1 & 1 & 1 & 1 & 1 \\
\hline $\mathrm{ACA} / \mathrm{CAG}-187$ & 1 & 1 & 1 & 11 & 1 & 11 & 11 & 1 & 1 & $1)$ & 1 \\
\hline $\mathrm{ACA} / \mathrm{CAG}-190$ & 1 & 1 & 1 & 1 & 1 & 1 & 11 & 1 & 1 & 1 & 1 \\
\hline ACA/CAG-206 & 1 & 1 & 1 & 1 & 1 & 0 & 1 & 1 & 1 & 1 & 0 \\
\hline $\mathrm{ACA} / \mathrm{CAG}-211$ & 11 & 1 & 1 & 1 & 11 & 1 & 1 & 1 & 1 & 1 & 1 \\
\hline $\mathrm{ACA} / \mathrm{CAG}-250$ & 1 & 1 & $1)$ & 1 & 1 & 1 & 1 & 1 & 1 & $1)$ & 1 \\
\hline $\mathrm{ACA} / \mathrm{CAG}-274$ & 1 & 1 & 1 & 1 & 1 & 1 & 1 & 1 & 1 & 1 & 1 \\
\hline ACA/CAG-286 & 14 & 1 & 1 & 1 & 1 & 11 & 1 & 1 & 14 & 1 & 1 \\
\hline ACA/CAG-295 & 1 & 1 & 1 & 11 & 1 & 1 & 1 & 1 & 1 & 1) & 1 \\
\hline $\mathrm{ACA} / \mathrm{CAG}-301$ & 1 & 14 & 1 & 1 & 1 & 1 & 1. & 1 & 1 & 1 & 1 \\
\hline $\mathrm{ACA} / \mathrm{CAG}-304$ & $1)$ & 1 & 1 & 0 & $1)$ & 14 & 1 & 1 & 1 & 1 & 0 \\
\hline $\mathrm{ACA} / \mathrm{CAG}-331$ & 1 & 0 & of & 1 & 1 & 1 & 0 & 1 & 1 & 1 & 0 \\
\hline $\mathrm{ACA} / \mathrm{CTC}-058$ & 1 & 1 & 1 & 1 & 1 & 1 & 11 & 1 & 11 & 1 & 1 \\
\hline $\mathrm{ACA} / \mathrm{CTC}-063$ & 0 & 0 & 0 & 0 & 0 & of & 0 & 0 & 0 & 0 & 0 \\
\hline $\mathrm{ACA} / \mathrm{CTC}-065$ & 0 & 0 & 1 & 1 & 0 & 1 & 1 & 1 & 0 & 1 & 1 \\
\hline $\mathrm{ACA} / \mathrm{CTC}-067$ & 0 & 0 & 0 & 0 & 0 & 0 & 0 & 0 & 0 & 0 & 0 \\
\hline ACA/CTC-070 & 1 & 1 & 1 & 1 & 1 & 1 & 1 & 1 & 1 & 1 & 1 \\
\hline ACA/CTC-076 & 0 & 1 & 0 & 1 & 0 & 0 & 0 & 0 & 0 & 1 & 0 \\
\hline ACA/CTC-098 & 0 & 0 & 0 & 0 & 0 & of & 0 & 0 & of & 0 & $\underline{0}$ \\
\hline $\mathrm{ACA} / \mathrm{CTC}-100$ & 1 & 1 & 1 & 1 & 1 & 0 & 1 & 0 & 1 & 1 & 1 \\
\hline ACA/CTC-102 & 1 & 1 & 1 & 1 & 1 & 1 & 1 & 1 & 1 & 1 & 1 \\
\hline ACA/CTC-106 & 1 & 1 & 1 & 1 & 1 & 0 & 1 & 1 & 1 & 1 & 1 \\
\hline ACA/CTC-107 & 0 & 0 & 0 & 0 & 0 & 1 & 0 & 1 & 0 & 0 & 1 \\
\hline $\mathrm{ACA} / \mathrm{CTC}-112$ & 1 & 1 & 1 & 0 & 1 & 1 & I & 0 & 1 & 0 & 1 \\
\hline $\mathrm{ACA} / \mathrm{CTC}-113$ & 1 & 1 & 0 & 0 & 0 & 0 & 0 & 0 & 1 & 0 & 0 \\
\hline $\mathrm{ACA} / \mathrm{CTC}-115$ & 1 & 1 & 1 & 1 & 1 & 1 & 1 & 1 & 1 & 1 & 1 \\
\hline $\mathrm{ACA} / \mathrm{CTC}-116$ & 1 & 1 & 1 & 1 & 1 & 1 & 1 & 1 & 1 & 1 & 1 \\
\hline $\mathrm{ACA} / \mathrm{CTC}-133$ & 1 & 1 & 1 & 1 & 1 & 1 & 14 & 1 & 1 & 1 & 1 \\
\hline ACA/CTC-140 & 1. & 1 & 1 & 1 & 1 & 1 & 1 & 1 & 1 & 1 & 1 \\
\hline $\mathrm{ACA} / \mathrm{CTC}-156$ & 0 & 0 & 0 & 0 & of & 0 & 0 & 0 & 0 & of & 0 \\
\hline $\mathrm{ACA} / \mathrm{CTC}-164$ & 0 & 1 & 0 & 0 & 01 & 0 & 0 & 0 & 0 & 01 & 1 \\
\hline
\end{tabular}


Anexo 2 - Presença e ausência de 134 bandas de AFLP

(Continuação)

\begin{tabular}{|c|c|c|c|c|c|c|c|c|c|c|c|}
\hline Banda & DG049 & \begin{tabular}{|l|} 
DG050 \\
\end{tabular} & \begin{tabular}{|l|} 
DG051 \\
\end{tabular} & DG052 & \begin{tabular}{|l|} 
DG054 \\
\end{tabular} & DG055 & \begin{tabular}{|l|l} 
DG056 \\
\end{tabular} & DG058 & DG059 & DG060 & DG061 \\
\hline ACA/CTC-171 & 0 & $\begin{array}{l}0 \\
\end{array}$ & 1 & 0 & 1 & $\begin{array}{r}0 \\
\end{array}$ & 1 & 0 & 0 & 0 & 1 \\
\hline ACA/CTC-187 & 1 & 1 & 1 & 1 & 0 & 0 & 0 & (0) & 1 & 1 & 0 \\
\hline $\mathrm{ACA} / \mathrm{CTC}-192$ & 1 & 1 & 1 & 11 & 1 & 1 & 1 & 1 & 1 & 1 & 1 \\
\hline ACA/CTC-201 & 1 & 1 & 1 & 1 & 1 & 1 & 1 & 1 & 1 & 1 & 1 \\
\hline ACA/CTC-210 & 1 & 11 & 0 & $\mathrm{I}$ & 1 & 0 & 11 & 1 & 1 & 1 & 1 \\
\hline ACA/CTC-212 & 0 & 1 & 0 & 0 & 1 & 0 & 1 & 0 & 0 & 0 & 0 \\
\hline $\mathrm{ACA} / \mathrm{CTC}-226$ & 0 & 0 & 0 & 1 & 0 & 0 & 0 & 0 & 0 & (1) & 0 \\
\hline $\mathrm{ACA} / \mathrm{CTC}-227$ & 0 & 0 & 0 & 0 & 0 & 0 & 0 & 0 & 0 & 0 & 1 \\
\hline ACA/CTC-230 & 1 & 0 & 0 & 1 & 1 & ] & 0 & 1 & 1 & of & 1 \\
\hline $\mathrm{ACA} / \mathrm{CTC}-244$ & 0 & 0 & 0 & 0 & 1 & 1 & 1 & 1 & 0 & 1 & 0 \\
\hline ACA/CTC-269 & 1 & 1 & 1 & 1 & 0 & 1 & 0 & 1 & 11 & 0 & 1 \\
\hline $\mathrm{ACA} / \mathrm{CTC}-270$ & 1 & 1 & 1 & 1 & 1 & 1 & 1 & 1 & 1 & 0 & 1 \\
\hline $\mathrm{ACA} / \mathrm{CTC}-287$ & 1 & 1 & 1 & 1 & 1 & 1 & 1 & 1 & 1 & 1 & 1 \\
\hline ACA/CTC-293 & 1 & 0 & 0 & 0 & 0 & 0 & 0 & 0 & 0 & 0 & 0 \\
\hline ACA/CTC-296 & 1 & 1) & 1 & 1 & 1 & 11 & 1 & 1 & 1 & 1 & 1 \\
\hline ACA/CTC-309 & 0 & 0) & 0 & 9 & 0 & of & 0 & 0 & 0 & 0 & 0 \\
\hline $\mathrm{ACA} / \mathrm{CTC}-322$ & 1 & 1 & 1 & 1 & 1 & 1 & 1 & 1 & 1 & 1 & 1 \\
\hline $\mathrm{ACT} / \mathrm{CAC}-062$ & 1) & 1 & 1) & 1 & 1) & 1 & 11 & 1 & 1) & 1 & 1 \\
\hline $\mathrm{ACT} / \mathrm{CAC}-064$ & 0 & 0 & 0 & 0 & 0 & 0 & 0 & 0 & 0 & 0 & 0 \\
\hline ACT/CAC-081 & 0 & 0 & 0 & 0 & 0 & 0 & 0 & 0 & 0 & 0 & 1 \\
\hline ACT/CAC-084 & 1 & 1 & 11 & 1 & 1 & 1 & 1 & 1 & 1 & 1 & 1 \\
\hline $\mathrm{ACT} / \mathrm{CAC}-089$ & 0 & 0 & 0 & 0 & 0 & 0 & 0 & 0 & 0 & 0 & 0 \\
\hline $\mathrm{ACT} / \mathrm{CAC}-091$ & 1 & 1 & 1 & 1 & 1 & 1) & 0 & 1 & 1 & 1 & 1 \\
\hline ACT/CAC-108 & 0 & 0 & 0 & 0 & 0 & 1 & 0 & 1 & 0 & 0 & 0 \\
\hline $\mathrm{ACT} / \mathrm{CAC}-110$ & 1 & 0 & 1 & 1 & 1 & 0 & 1 & 1 & 1 & 0 & 1 \\
\hline $\mathrm{ACT} / \mathrm{CAC}-116$ & 0 & 0 & 0 & 1 & 1 & 0 & 0 & 1 & 0 & 1 & 0 \\
\hline ACT/CAC-118 & 0 & 1 & 1 & 0 & 0 & 1 & 0 & 0 & 0 & 1 & 0 \\
\hline $\mathrm{ACT} / \mathrm{CAC}-120$ & 1 & 11 & 1 & 1 & 1 & 1 & 1 & 1 & 1 & 1 & 1 \\
\hline ACT/CAC-124 & 1 & 1) & 1 & 0 & 0 & 0 & 0 & 1 & 1 & 1 & 1 \\
\hline $\mathrm{ACT} / \mathrm{CAC}-127$ & 0 & 0 & 0 & 0 & 0 & 0 & 0 & 0 & 0 & 0 & 0 \\
\hline $\mathrm{ACT} / \mathrm{CAC}-140$ & 1 & 1 & 1 & 1 & 1 & 0 & 1 & 0 & 1 & 1 & 0 \\
\hline $\mathrm{ACT} / \mathrm{CAC}-143$ & 1 & 0 & 1 & 1 & 1 & 0 & 0 & 0 & 1 & 1 & 0 \\
\hline ACT/CAC-164 & 1 & 1 & 1 & 1 & 11 & 1 & 11 & 1 & 1 & 0 & 1 \\
\hline $\mathrm{ACT} / \mathrm{CAC}-167$ & 1 & 1 & 1 & 1 & 1) & 1 & 1 & 1 & 1 & 1 & 1 \\
\hline $\mathrm{ACT} / \mathrm{CAC}-175$ & 1 & 1 & 1 & 1 & 1 & 1 & $1]$ & 0 & 1 & 0 & 1 \\
\hline $\mathrm{ACT} / \mathrm{CAC}-188$ & 0 & 0 & 0 & 0 & 0 & 0 & 0 & 0 & 0 & 0 & 0 \\
\hline ACT/CAC-189 & 1 & 1 & 1 & 1 & 1 & 1 & 0 & 1 & 1 & 0 & 1 \\
\hline ACT/CAC-201 & 0 & 0 & 1 & 0 & 1 & 1] & 0 & 0 & 0 & 0 & 0 \\
\hline ACT/CAC-214 & 0 & 1 & 0 & 11 & 0 & $0]$ & 1 & 0 & 0 & 1 & 0 \\
\hline ACT/CAC-226 & 1 & 1 & 1 & 1 & 1 & 1 & 1 & 0 & 1 & 1) & 1 \\
\hline ACT/CAC-230 & 0 & 0 & 1 & 0 & 0 & 0 & 0 & 0 & 0 & 1 & 0 \\
\hline $\mathrm{ACT} / \mathrm{CAC}-234$ & 1 & 1 & 1 & 1 & 1 & 1 & 1 & 1 & 1 & 1 & 1 \\
\hline ACT/CAC-276 & 1 & 11 & 1 & 1 & 1 & 1 & 1 & 1 & 1 & 1 & 1 \\
\hline ACT/CAC-310 & 1 & 1 & 1 & 1 & 1 & 1 & 1 & 1 & 1 & 1 & 1 \\
\hline ACT/CAC-340 & 0 & 1 & 0 & 0 & 0 & 0 & 1 & 0 & 0 & 0 & 0 \\
\hline AGG/CAA-054 & 1 & 1 & 1 & 11 & 1 & 1 & 11 & 1 & 1 & 1 & 1 \\
\hline AGG/CAA-056 & 0 & 1 & 0 & 0 & 0 & 0 & 0 & 0 & 0 & 0 & 0 \\
\hline AGG/CAA-057 & 1 & 0 & 1 & 1 & 1 & 1 & 1 & 1 & 1 & 1 & 0 \\
\hline $\mathrm{AGG} / \mathrm{CAA}-060$ & 1 & 1 & 1 & 1 & 1 & 1 & 1 & II & 1 & 1 & 1 \\
\hline $\mathrm{AGG} / \mathrm{CAA}-065$ & 0 & 0 & 0 & 1 & 1 & 0 & 0 & 0 & 0 & 1 & 0 \\
\hline AGG/CAA-070 & 1 & 1 & 1 & 1 & 1 & 1 & 1 & 1) & 1 & 1 & 1 \\
\hline AGG/CAA-071 & 1 & & 0 & 0 & 1 & 0 & 0 & 1 & 1 & 1 & 0 \\
\hline
\end{tabular}


Anexo 2 - Presença e ausência de 134 bandas de AFLP

(Continuação)

\begin{tabular}{|c|c|c|c|c|c|c|c|c|c|c|c|}
\hline Banda & DG049 & DG050 & DG051 & DG052 & DG0154 & DG055 & DG056 & DG058 & DG059 & DG060 & DG061 \\
\hline AGG/CAA-072 & 1 & 1 & 1 & 1 & $\begin{array}{r}1 \\
\end{array}$ & 1 & 1 & 1 & 1 & 1 & 1 \\
\hline $\mathrm{AGG} / \mathrm{CAA}-075$ & 1 & 1 & 1 & 1 & 1 & 1 & 1 & 1 & 1 & 1 & 1 \\
\hline $\mathrm{AGG} / \mathrm{CAA-078}$ & 1 & 1 & 1 & 1 & 1 & 1 & 1 & 1 & 1 & 1 & 1 \\
\hline AGG/CAA-079 & 1 & 1 & 1. & 1 & 1 & 1 & 0 & 1 & 1 & 0 & 0 \\
\hline AGG/CAA-080 & 1 & 11 & 1 & 1 & 1 & 1 & 1 & 1 & 1 & 1 & 1 \\
\hline AGG/CAA-083 & 0 & 0 & 1 & 1 & 1 & 0 & 1 & 0 & 0 & 0 & 0 \\
\hline AGG/CAA-093 & 1 & 1 & 1 & 1 & 1 & 1 & 1 & 1 & 1 & 1 & 1 \\
\hline AGG/CAA-103 & 1 & 1 & 1 & 1 & 1 & 1 & 1 & 1 & 1 & 1 & 1 \\
\hline AGG/CAA-109 & 1 & 1 & 0 & 0 & 0 & 0 & 0 & 0 & 1 & 0 & 0 \\
\hline AGG/CAA-125 & 1 & 1 & 1 & 1 & 1 & 1 & 1 & 1 & 1 & 1 & 1 \\
\hline AGG/CAA-131 & 0 & of & 0 & 0 & 0 & 1 & 0 & 0 & 0 & 0 & 0 \\
\hline $\mathrm{AGG} / \mathrm{CAA}-134$ & 1 & 1 & 1 & 1 & 1 & 1 & 1 & 1 & 1 & 1 & 1 \\
\hline AGG/CAA-141 & 0 & 0 & 0 & 11 & 1 & 0 & 1 & 0 & 0 & 1 & 0 \\
\hline AGG/CAA-142 & 0 & 0 & 0 & 0 & 0 & 0 & 0 & 0 & 0 & 0 & 0 \\
\hline $\mathrm{AGG} / \mathrm{CAA}-146$ & 1 & 1 & 1 & 1 & 1 & 1 & 1 & 1 & 1 & 1 & 1 \\
\hline $\mathrm{AGG} / \mathrm{CAA}-149$ & 1 & 1 & i) & 1 & 1 & 1 & 1 & 1 & 1 & 1 & 1 \\
\hline AGG/CAA-152 & 1 & 1 & 1 & 1 & 1 & 1 & 1 & 1 & 1 & 1 & 1 \\
\hline AGG/CAA-163 & 0 & 0 & 0 & 0 & 0 & 0 & 0 & 0 & 0 & 0 & 0 \\
\hline AGG/CAA-173 & 1 & 1 & 1 & 1 & 1 & 1 & 1 & 1 & 1 & 1 & 1 \\
\hline AGG/CAA-181 & 1 & 0 & 1 & 0 & 0 & 1 & 1 & 1 & 1 & 1 & 1 \\
\hline $\mathrm{AGG} / \mathrm{CAA}-203$ & 1 & 1 & 1 & 1 & 1 & 1 & 1 & 1 & 1 & 1 & 1 \\
\hline AGG/CAA-205 & 0 & 0 & 0 & 1 & 0 & 0 & 0 & 0 & 0 & 0 & 0 \\
\hline AGG/CAA-209 & 1 & 1 & 1 & 1 & 1 & 1 & 1 & 1 & 1 & 1 & 1 \\
\hline AGG/CAA-210 & 1 & 1 & 1 & 1 & 1 & 1 & 1 & 1 & 1 & 1 & 1 \\
\hline AGG/CAA-216 & 1 & 1 & 1 & 1 & 0 & 1 & 0 & 1 & 1 & 0 & 0 \\
\hline AGG/CAA-265 & 0 & 0 & 0 & 0 & 1 & 0 & 0 & 0 & 0 & 1 & 1 \\
\hline AGG/CAA-285 & 1 & 1 & 1 & 1 & 1 & 1 & 1 & 1 & 1 & 1 & 1 \\
\hline AGG/CAA-315 & 0 & 0 & 0 & 0 & 1 & $\mathrm{I}$ & 1 & 1 & 0 & 1 & 0 \\
\hline $\mathrm{AGG} / \mathrm{CAA}-327$ & 1 & 1 & 1 & 1 & 1 & 1 & 1 & 1 & 1 & 1 & 1 \\
\hline $\mathrm{AGG} / \mathrm{CAA}-347$ & 1 & 1 & 1 & 1 & 1 & 1 & 1 & 1 & 1 & 1 & 1 \\
\hline
\end{tabular}


Anexo 2 - Presença e ausência de 134 bandas de AFLP

(Continuação)

\begin{tabular}{|c|c|c|c|c|c|c|c|c|c|c|c|}
\hline Banda & DG062 & DG065 & DG067 & DG068 & DG069 I & DG070 & $\mathrm{DG} 073$ & DG111 & DG112 & DG113 I & DG114 \\
\hline $\mathrm{ACA} / \mathrm{CAG}-051$ & 0 & 1 & 1 & 1 & 1 & 1 & 0 & 0 & 1 & 1 & 1 \\
\hline $\mathrm{ACA} / \mathrm{CAG}-052$ & 1 & 0 & 11 & 0 & 0 & 0 & 0 & 0 & 0 & 0 & 0 \\
\hline $\mathrm{ACA} / \mathrm{CAG}-056$ & 1 & 1 & 1 & 11 & 1 & 1 & 1 & 1 & 1 & 1 & 1 \\
\hline $\mathrm{ACA} / \mathrm{CAG}-058$ & 1 & of & 0 & 0 & 0] & of & 0 & 0) & 0 & 0 & 0 \\
\hline $\mathrm{ACA} / \mathrm{CAG}-060$ & 1 & 1 & 1 & 1 & 1 & 1 & 1) & 11 & 1 & 11 & 1 \\
\hline ACA/CAG-063 & 1 & 11 & 1 & 1 & 1 & 1 & 1 & 1 & 1 & 11 & 1 \\
\hline $\mathrm{ACA} / \mathrm{CAG}-066$ & 1 & 0 & 1 & 1 & 1 & 1 & 1 & of & 1 & 0 & 1 \\
\hline $\mathrm{ACA} / \mathrm{CAG}-069$ & 1 & 1 & 1 & 1 & 1 & 1 & 1 & 1 & 1 & 11 & 0 \\
\hline $\mathrm{ACA} / \mathrm{CAG}-071$ & 1 & 1 & 1 & $1)$ & of & 1 & 1 & $1]$ & 1 & $1)$ & 0 \\
\hline $\mathrm{ACA} / \mathrm{CAG}-074$ & 1 & 1 & 1 & 1 & 1 & 1 & 1 & 1 & 1 & 11 & 1 \\
\hline $\mathrm{ACA} / \mathrm{CAG}-075$ & 1 & 1 & 11 & 1 & 1 & 1 & 1 & 1 & 1 & 1 & 1 \\
\hline ACA/CAG-079 & 1 & 1 & 1 & 1 & 1 & $1)$ & 0 & 1 & 1 & $1)$ & 요 \\
\hline $\mathrm{ACA} / \mathrm{CAG}-082$ & 1 & 11 & 1 & 1 & 1 & 1 & 1 & 1 & 1 & 1 & 1 \\
\hline $\mathrm{ACA} / \mathrm{CAG} 085$ & 1 & 1 & 1 & 1 & $1)$ & ] & 1 & 1 & 1 & 1 & 1 \\
\hline ACA/CAG-089 & 1 & 1 & 1 & 1 & 1 & 11 & 1 & of & of & 요 & 1 \\
\hline ACA/CAG-094 & 0 & 1 & 1 & 1 & 11 & 1 & 1 & 1 & 1 & 1 & 1 \\
\hline $\mathrm{ACA} / \mathrm{CAG}-095$ & 14 & of & $1)$ & 1 & 0 & 1 & 0 & 요 & 1 & 1 & 1 \\
\hline $\mathrm{ACA} / \mathrm{CAG}-110$ & 1 & 1 & 1 & 1 & 1 & 1 & 1 & 1 & 1 & 1 & 1 \\
\hline $\mathrm{ACA} / \mathrm{CAG}-113$ & 1 & 1 & 1 & 11 & 11 & 1 & 1 & 1 & 1 & 1 & 1 \\
\hline $\mathrm{ACA} / \mathrm{CAG}-143$ & 1 & 1 & 1 & 1 & 0) & 1 & 1 & 0 & 1 & of & 1 \\
\hline $\mathrm{ACA} / \mathrm{CAG}-156$ & 요 & 0 & of & 0 & 1 & of & of & 0 & of & 0 & 0 \\
\hline $\mathrm{ACA} / \mathrm{CAG}-159$ & 1 & 1 & 1 & 1 & 0 & 1 & 1 & 11 & 1 & 1 & 1 \\
\hline $\mathrm{ACA} / \mathrm{CAG}-187$ & 1 & $1)$ & 1) & 1) & 1 & 11 & 1 & 1 & of & 1 & 1 \\
\hline $\mathrm{ACA} / \mathrm{CAG}-190$ & 1 & 1 & 1 & 1 & 1 & 11 & 1 & 1 & 1 & 1 & 1 \\
\hline ACA/CAG-206 & 0 & 1 & 0 & 이 & 1 & 1 & 1 & 1 & 1 & 1 & 1 \\
\hline ACA/CAG-211 & 1 & 1 & 1 & 1 & 1 & 1 & 1 & 1 & 1 & 1 & 1 \\
\hline ACA/CAG-250 & 1 & 11 & 1 & 1 & 1 & 1 & 1 & 1 & 1 & 1 & 1 \\
\hline $\mathrm{ACA} / \mathrm{CAG}-274$ & (1) & 1 & 1 & 1 & 1 & 1 & 1 & 1 & 1 & 1 & 1 \\
\hline $\mathrm{ACA} / \mathrm{CAG}-286$ & 1 & 1 & 1 & 1 & 1 & 1 & 1 & $1)$ & 1 & $1)$ & 1 \\
\hline $\mathrm{ACA} / \mathrm{CAG}-295$ & 0 & 1 & 1 & 1 & 1 & 1 & 1 & 1 & 1 & 1 & 1 \\
\hline ACA/CAG-301 & 1 & 1 & 1 & 1 & 1 & 1 & 1 & 1 & 1 & 1 & 1 \\
\hline $\mathrm{ACA} / \mathrm{CAG}-304$ & 1 & 1 & 1 & 0 & 1 & 1 & 1 & 1 & 1) & 1 & 1 \\
\hline $\mathrm{ACA} / \mathrm{CAG}-331$ & 0 & 0 & 1 & 0 & 1 & 11 & 요 & 1 & 1 & 1 & 1 \\
\hline ACA/CTC- 058 & 1 & 1 & 1 & 1 & 11 & 11 & $1)$ & 1 & 1 & 1 & 1 \\
\hline $\mathrm{ACA} / \mathrm{CTC}-063$ & 0 & 0 & 0 & 0) & 요 & 요 & 1 & 0 & 0 & 이 & 0 \\
\hline $\mathrm{ACA} / \mathrm{CTC}-065$ & 0 & 0 & 1 & 1 & 요 & 0 & 0 & 1 & 1 & 1 & 1 \\
\hline $\mathrm{ACA} / \mathrm{CTC}-067$ & 1 & 0 & 0 & 요 & 0 & 0 & 요 & 0 & 0 & of & 0 \\
\hline ACA/CTC-070 & 1 & 11 & 11 & 1 & 1 & 1 & 1 & 1 & 1 & 1 & 1 \\
\hline ACA/CTC-076 & 0 & 1 & 0 & 요 & 이 & 0 & 요 & 0) & 0 & 아 & 0 \\
\hline ACA/CTC-098 & 0 & 요 & 0 & 요 & of & 0 & 요 & of & 요 & 0 & 0 \\
\hline ACA/CTC-100 & 0 & 1 & 1 & $1)$ & 11 & 1 & 1 & 11 & 1 & 1 & 1 \\
\hline ACA/CTC-102 & 1 & 1 & 1 & 1 & 1 & 1 & 1 & 1) & 1 & 1 & 1 \\
\hline $\mathrm{ACA} / \mathrm{CTC}-106$ & 1 & 1) & 1 & 1 & 1 & 1 & 1 & 1 & 1 & 1 & 1 \\
\hline ACA/CTC-107 & 1 & 1 & 1 & 1 & 요 & 1 & 1 & 1 & 1 & 1 & 1 \\
\hline $\mathrm{ACA} / \mathrm{CTC}-112$ & 0 & 0 & 1) & 1 & of & 1) & 1 & 1 & $1)$ & 1 & 0 \\
\hline $\mathrm{ACA} / \mathrm{CTC}-113$ & 0 & 1 & 1 & 0 & 1 & 0 & of & of & 1 & 0 & 1 \\
\hline ACA/CTC-115 & 1 & 1 & 1 & 1 & 1 & 1 & 1 & 1 & 1 & 1 & 1 \\
\hline ACA/CTC-116 & 1 & 1 & 1 & 1 & of & 1 & 1 & of & 0 & 1 & 1 \\
\hline $\mathrm{ACA} / \mathrm{CTC}-133$ & 1 & 1 & 1 & 1 & 1 & 1 & 1 & 1 & 1 & 1 & 1 \\
\hline ACA/CTC -140 & 아 & $1]$ & 1 & 1 & 1 & 1 & 1 & 1 & 1 & 1 & 1 \\
\hline ACA/CTC-156 & 이 & $1)$ & 0 & 0 & 1 & 0 & 1 & 0 & 0 & 요 & 0 \\
\hline $\mathrm{ACA} / \mathrm{CTC}-164$ & 이 & 11 & 0 & 1 & 1) & 0 & 1) & 0 & 1 & 11 & 0 \\
\hline
\end{tabular}


Anexo 2 - Presença e ausência de 134 bandas de AFLP

(Continuação)

\begin{tabular}{|c|c|c|c|c|c|c|c|c|c|c|c|}
\hline Banda & DG062 & DG065 & \begin{tabular}{|l|} 
DG067 \\
\end{tabular} & \begin{tabular}{|l|}
$\mathrm{DG} 068$ \\
\end{tabular} & \begin{tabular}{|l|} 
DG069 \\
\end{tabular} & DG070 & DG073 & DG111 & DG112 & DG113 & DG114 \\
\hline ACA/CTC-171 & 0 & 0 & 0 & 1 & 0 & 0 & 0 & 1 & 0 & 0 & 0 \\
\hline ACA/CTC-187 & 0 & 0 & 1 & 0 & 0 & 0 & 0 & 0 & 1 & 1 & 1 \\
\hline ACA/CTC-192 & 1 & 1 & 1 & 1 & 1 & 1 & 1 & 1 & 1 & 1 & 1 \\
\hline ACA/CTC-201 & 1) & 1 & 1) & 1 & 1 & 1 & 1 & 1 & ] & 1) & 1 \\
\hline ACA/CTC-210 & 1 & 1 & 1 & 0 & 1 & 1 & 1 & 1 & 1 & 1 & 1 \\
\hline ACA/CTC-212 & 0 & 1 & 0 & 0 & 0 & 0 & 0 & 0 & 0 & 0 & 0 \\
\hline $\mathrm{ACA} / \mathrm{CTC}-226$ & 0 & 0 & 0 & 0 & 0 & 0 & 1 & 0 & 0 & 0 & 0 \\
\hline $\mathrm{ACA} / \mathrm{CTC}-227$ & 0 & 0 & 0 & 1 & 0 & 0 & 0 & 0 & 0 & 0 & 0 \\
\hline ACA/CTC-230 & 1 & 0 & 0 & I) & 0 & 0 & 0 & 0 & 0 & 0 & 0 \\
\hline ACA/CTC-244 & 1 & 1 & 1 & 0 & 0 & 0 & 1) & 1 & 1 & 1 & 1 \\
\hline ACA/CTC-269 & 1) & 0 & 0 & 1 & 0 & 1 & 1) & 1 & 1 & 1 & 1 \\
\hline ACA/CTC-270 & I] & 0 & 0 & 0 & 1 & 1 & 1 & 1 & 1 & 1 & 1 \\
\hline ACA/CTC-287 & 1 & 1 & 1 & 1 & 1 & 1 & 1 & 11 & 1 & 1 & 1 \\
\hline ACA/CTC-293 & 0 & 0 & 0 & 0 & 1 & 1 & 0 & 0 & 1 & 0 & 1 \\
\hline ACA/CTC-296 & 1 & 1 & 1 & 1 & 1 & 1 & 0 & 1 & 1 & 1 & 1 \\
\hline ACA/CTC-309 & 0 & 0 & 0 & 0 & 0 & 0 & 0 & 0 & 0 & 0 & 1 \\
\hline ACA/CTC-322 & 1 & 1 & 1 & 1 & 1 & 1 & 1 & 1 & 1 & 1 & 1 \\
\hline $\mathrm{ACT} / \mathrm{CAC}-062$ & 1 & 1 & 1 & 1 & 1 & 1 & 1 & 1 & 1 & 1 & 1 \\
\hline ACT/CAC-064 & 11 & 0 & 0 & 0 & 0 & 0 & 0 & 0 & 0 & 0 & 0 \\
\hline ACT/CAC-081 & 0 & 0 & 0 & 1 & 0 & 0 & 0 & 0 & 0 & 0 & 1 \\
\hline ACT/CAC-084 & 1 & 1 & 1 & 1 & 1 & 1 & 1 & 1 & 1 & 1 & 1 \\
\hline ACT/CAC-089 & 0 & 0 & 0 & 0 & 0 & 0 & 0 & 0 & 0 & 0 & 0 \\
\hline $\mathrm{ACT} / \mathrm{CAC}-091$ & 1 & 0 & 0 & 1 & 0 & 0 & 1 & 1 & 1 & 0 & 1 \\
\hline ACT/CAC-108 & 1 & 1 & 1 & 0 & 1 & 0 & 0 & 1 & 0 & 1 & 0 \\
\hline $\mathrm{ACT} / \mathrm{CAC}-110$ & 1 & 1 & 1 & 1 & 1 & 1 & 11 & 1 & 1 & 1 & 0 \\
\hline $\mathrm{ACT} / \mathrm{CAC}-116$ & 0 & 0 & 0 & 0 & 0 & 0 & 0 & 1 & 1 & 1 & 1 \\
\hline ACT/CAC-118 & 0 & 0 & 0 & 0 & 1 & 1 & 1 & 0 & 0 & 0 & 0 \\
\hline$A C T / C A C-120$ & 1 & 1 & 1 & 1 & 1 & 1 & 1 & 1 & 1 & 1 & 1 \\
\hline $\mathrm{ACT} / \mathrm{CAC}-124$ & 1 & 1 & 1 & 1 & 1 & 0 & 0 & 1 & 1 & 0 & 0 \\
\hline ACT/CAC-127 & 0 & 1 & 0 & 0 & 0 & 0 & 0 & 0 & 0 & 0 & 0 \\
\hline $\mathrm{ACT} / \mathrm{CAC}-140$ & 0 & 1 & 1 & 0 & 1 & 1 & 1 & 1 & 1 & 1 & 1 \\
\hline $\mathrm{ACT} / \mathrm{CAC}-143$ & 0 & 1 & 0 & 0 & 0 & 1 & 0 & 0 & 0 & 0 & 1 \\
\hline ACT/CAC-164 & 1 & 1 & 1 & 1 & 1 & 0 & 1 & 0 & 0 & 1 & 1 \\
\hline ACT/CAC-167 & 1 & 1) & 1 & 1 & 1 & 1 & 1 & 1 & 1 & 1 & 1 \\
\hline ACT/CAC-175 & 1 & 1) & 1 & 11 & 1 & 1 & 1 & 0 & 0 & 0 & 0 \\
\hline $\mathrm{ACT} / \mathrm{CAC}-188$ & 0 & 1 & 1 & 0 & 11 & 0 & 1 & 0 & 0 & 0 & 0 \\
\hline ACT/CAC-189 & 1 & 1 & 0 & 1) & 1) & 1 & 1 & 1 & 0 & 1 & 1 \\
\hline $\mathrm{ACT} / \mathrm{CAC}-201$ & 0 & 0 & 0 & 0 & 0 & 0 & 0 & 1 & 1 & 1 & 0 \\
\hline $\mathrm{ACT} / \mathrm{CAC}-214$ & 0 & 0 & 0 & 0 & 1 & 0 & 0 & 1 & 1 & 0 & 1 \\
\hline $\mathrm{ACT} / \mathrm{CAC}-226$ & 0 & 0 & 1 & 1 & 1 & 1 & 1 & 1 & 1 & 0 & 1 \\
\hline ACT/CAC-230 & 0 & 1 & 1 & 0 & 1 & 0 & 0 & 0 & 0 & 0 & 0 \\
\hline ACT/CAC-234 & 1 & 1 & 1 & 1 & 1 & 1 & 1 & 1 & 1 & 1 & 1 \\
\hline ACT/CAC-276 & 1 & 1 & 1 & 1 & 1 & 1 & 1 & 1 & 1 & 1 & 1 \\
\hline ACT/CAC-310 & 1 & 1 & 1 & 1 & 1 & 1 & 1 & 1 & 1 & 1 & 1 \\
\hline ACT/CAC-340 & 0 & 0 & 0 & 0 & 0 & 0 & 0 & 0 & 0 & 0 & 0 \\
\hline AGG/CAA-054 & 1 & I) & 1 & 1 & 1 & 1 & 1 & 1 & 1 & 1 & 1 \\
\hline AGG/CAA-056 & 0 & 0 & 0 & 0 & 0 & 0 & 0 & 0 & 0 & 0 & 0 \\
\hline AGG/CAA-057 & 1 & 1 & 0 & 0 & 0 & 0 & 0 & 1 & 1 & 1 & 1 \\
\hline $\mathrm{AGG} / \mathrm{CAA}-060$ & 1 & 1 & 1 & 1 & 1 & 1 & 1 & 1 & 1 & 1 & 1 \\
\hline AGG/CAA-065 & 0 & 1 & 0 & 0 & 0 & 0 & 0 & 0 & 0 & 0 & 0 \\
\hline AGG/CAA-070 & 1) & 1 & 1 & 11 & 1 & 11 & 1 & 1 & 1 & 1 & 1 \\
\hline AGG/CAA-071 & 1 & 1 & 0 & 0 & 0 & 1 & 0 & 0 & 1 & 1 & 0 \\
\hline
\end{tabular}


Anexo 2 - Presença e ausência de 134 bandas de AFLP

(Continuação)

\begin{tabular}{|c|c|c|c|c|c|c|c|c|c|c|c|}
\hline Banda & DG062 & DG065 & DG067 & DG068 & DG069 & DG070 & DG073 & DG111 & DG112 & DG113 & DG114 \\
\hline $\mathrm{AGG} / \mathrm{CAA}-072$ & 1 & 1 & 1 & 1 & 1 & 11 & 1 & 1 & 1 & $1]$ & 1 \\
\hline $\mathrm{AGG} / \mathrm{CAA}-075$ & 1 & 11 & 1 & 1 & 1 & 1 & 1 & $1]$ & 1 & 11 & 1 \\
\hline $\mathrm{AGG} / \mathrm{CAA}-078$ & 1 & 1 & 1 & 1 & 1 & 1 & 1 & 1 & 1 & 1 & 1 \\
\hline AGG/CAA-079 & 1 & 0 & 1 & 0 & 이 & 0 & 0 & 1 & 1 & $1)$ & 1 \\
\hline $\mathrm{AGG} / \mathrm{CAA}-080$ & 1 & 1) & 1 & 1 & 1 & 1 & 1 & 11 & I) & 1 & 1 \\
\hline AGG/CAA-083 & 0 & 0 & 이 & 0 & 0 & 0 & 0 & 0 & 0 & 0 & 0 \\
\hline $\mathrm{AGG} / \mathrm{CAA}-093$ & 1 & 1 & 1 & 1 & 1 & 1 & 1 & 1 & 1 & 1 & 1 \\
\hline $\mathrm{AGG} / \mathrm{CAA}-103$ & 1 & 1 & 1 & 1 & 1 & 1 & 1 & 1 & 1 & 1 & 1 \\
\hline $\mathrm{AGG} / \mathrm{CAA}-109$ & 0 & 1 & 1 & 0 & 요 & 1 & 0 & 0 & 0 & 1 & 0 \\
\hline $\mathrm{AGG} / \mathrm{CAA}-125$ & 1 & 1 & 1 & 1 & 1 & 1 & 1 & 1 & 1 & 1 & 1 \\
\hline AGG/CAA-131 & 0 & 0 & 0 & 0 & 0 & 0 & 0 & 0 & 1 & 0 & 0 \\
\hline $\mathrm{AGG} / \mathrm{CAA}-134$ & 1. & 1 & 1 & 1 & 1 & 1 & 1 & 1 & 0 & 1 & 1 \\
\hline $\mathrm{AGG} / \mathrm{CAA}-141$ & 요 & 1 & 1 & 0 & 1 & 1 & 0 & 0 & 0 & of & 1 \\
\hline AGG/CAA-142 & 0 & of & 1 & 0 & 1 & 0 & 0 & 0 & 0 & 1 & 0 \\
\hline AGG/CAA-146 & 1 & 1 & 1 & 1 & 1 & 1 & 1 & 1 & 1 & 1 & 1 \\
\hline AGG/CAA-149 & 1 & 1 & $1)$ & 1 & 1 & 1 & 1 & 1 & 1 & 1 & 1 \\
\hline AGG/CAA-152 & 1 & 1 & 1 & 1 & 1 & 1 & 1 & 1 & 1 & 1 & 1 \\
\hline $\mathrm{AGG} / \mathrm{CAA}-163$ & 0 & 0 & 0 & 0 & 0 & 0 & 0 & 0 & 0 & 0 & 0 \\
\hline AGG/CAA-173 & 1 & 1 & 1 & 1) & 1 & 1 & 1 & 1 & 1 & 1 & 1 \\
\hline AGG/CAA-181 & 1 & 1 & 이 & 1 & 1 & 0 & 0 & 1 & 1 & 1 & 1 \\
\hline AGG/CAA-203 & 1 & 1 & 1 & 1 & 1 & 1 & 1 & 1 & 1 & 1 & 1 \\
\hline AGG/CAA-205 & 0 & 0 & 0 & 0 & 0 & 1 & 0 & 0 & 0 & 0 & 0 \\
\hline $\mathrm{AGG} / \mathrm{CAA}-209$ & 0 & 1 & 1 & 1 & 1 & 1 & 1 & 1 & 1 & 1 & 1 \\
\hline AGG/CAA-210 & 1 & 1 & 1 & 1 & 1 & 1 & 1 & 1 & 1 & 1 & 1 \\
\hline AGG/CAA-216 & 1 & 1 & 1 & 0 & 1 & 1 & 0 & 0 & 0 & 1 & 1 \\
\hline AGG/CAA-265 & 0 & 0 & 1 & 1 & of & 0 & 0 & 0 & 0 & 1 & 1 \\
\hline AGG/CAA-285 & 1 & 1 & 1 & 1 & 1 & 1 & 1 & 1 & 1 & 1 & 1 \\
\hline AGG/CAA-315 & 0 & 0 & 0 & 0 & 1 & 1 & 1 & 0 & 0 & 1 & 1 \\
\hline AGG/CAA-327 & 1 & 1 & 1 & 1 & 1 & 1 & 1 & 1 & 1 & 1 & 1 \\
\hline AGG/CAA-347 & 1 & 1 & 1 & 1 & 1 & 1 & 1 & 1 & 1 & 1 & 1 \\
\hline
\end{tabular}


Anexo 2 - Presença e ausência de 134 bandas de AFLP

(Continuação)

\begin{tabular}{|c|c|c|c|c|c|c|c|c|c|c|c|}
\hline Banda & \begin{tabular}{|l|} 
DG115 \\
\end{tabular} & \begin{tabular}{|l|l} 
DG116 \\
\end{tabular} & \begin{tabular}{|l|} 
DG118 \\
\end{tabular} & DG138 & DG117 & \begin{tabular}{|l|} 
DG119 \\
\end{tabular} & \begin{tabular}{|l|l|} 
DG120 I \\
\end{tabular} & DG121 & DG122 & DG123 & DG124 \\
\hline $\mathrm{ACA} / \mathrm{CAG}-051$ & 0 & 1 & 1) & 1 & 1 & 1 & 1 & 1 & 0 & 0 & 0 \\
\hline $\mathrm{ACA} / \mathrm{CAG}-052$ & 1 & 0 & 1 & 0 & 1 & 0 & 0 & 0 & 1 & 0 & 0 \\
\hline $\mathrm{ACA} / \mathrm{CAG}-056$ & 1 & 1 & 1) & 1 & 1 & 1 & 1) & 1 & 1 & 1] & 1 \\
\hline ACA/CAG-058 & 0 & 0 & 0 & 0 & 0 & 0 & 0 & 0 & 0 & 0 & 0 \\
\hline $\mathrm{ACA} / \mathrm{CAG}-060$ & 1 & 1 & 1 & 1 & 1) & 1 & 1 & 1 & 1 & 1 & $1]$ \\
\hline $\mathrm{ACA} / \mathrm{CAG}-063$ & 1 & 1 & 1 & 1 & 1 & 1 & 1 & 1 & 1 & 11 & 1 \\
\hline ACA/CAG-066 & 0 & 1 & 1 & 1 & 1 & 1 & 1 & 1 & 1) & 1 & 1 \\
\hline ACA/CAG-069 & 1 & 11 & 1 & 11 & 1 & 1 & 1 & 1 & 1 & 1 & 0 \\
\hline $\mathrm{ACA} / \mathrm{CAG}-071$ & 1 & 1 & 1 & 1 & 1 & 1 & 1 & 1 & 1 & 11 & 1 \\
\hline $\mathrm{ACA} / \mathrm{CAG}-074$ & 1 & 1 & 1 & 1 & 1 & 1 & 1 & 1 & 1) & 1 & 1 \\
\hline ACA/CAG-075 & 1 & 1 & 1 & 1 & 1 & 1 & 1 & 1 & 1 & 1 & 1 \\
\hline $\mathrm{ACA} / \mathrm{CAG}-079$ & 1 & 1 & 1 & 1 & 1 & 1 & 1 & 1 & 0 & 1 & 1 \\
\hline $\mathrm{ACA} / \mathrm{CAG}-082$ & 1 & 1 & 1 & 1 & 1 & 1 & 1 & 1 & 1 & 1 & 1 \\
\hline ACA/CAG-085 & 1 & 1 & 1 & 1 & 1 & 1 & 1 & 1 & 1 & 1 & 1 \\
\hline ACA/CAG-089 & 0 & 0 & 1 & 1 & 1 & 1 & 1 & 0 & 1 & 0 & 1 \\
\hline $\mathrm{ACA} / \mathrm{CAG}-094$ & 11 & 1 & 1 & 1 & 1 & 1 & 1 & 1 & 1 & 1 & 1 \\
\hline $\mathrm{ACA} / \mathrm{CAG}-095$ & 0 & 1 & 0 & 1) & 0 & 0 & 1 & 0 & 0 & 0 & 0 \\
\hline $\mathrm{ACA} / \mathrm{CAG}-110$ & 1 & 1 & 1 & 1 & 1 & 1 & 1 & 11 & 1 & 1 & 1 \\
\hline $\mathrm{ACA} / \mathrm{CAG}-113$ & 1) & 1 & 1 & 1 & 1 & 1 & 1 & 1 & 1 & 11 & 1 \\
\hline $\mathrm{ACA} / \mathrm{CAG}-143$ & 0 & 1 & 1 & 1) & 1 & 1 & 1 & 11 & 1 & 1 & 1 \\
\hline ACA/CAG-156 & 1 & 0 & 0 & 0 & 0 & 0 & 0 & 0 & 1 & 1 & 0 \\
\hline ACA/CAG-159 & 1 & 1 & 1 & 1 & 1 & 1 & 1 & 1 & 1 & 1 & 1 \\
\hline ACA/CAG-187 & 0 & 0 & 1 & 1 & 1) & 1 & 1) & 1 & 1) & 1 & 1 \\
\hline $\mathrm{ACA} / \mathrm{CAG}-190$ & 1 & 1 & 1 & 1 & 1 & 1 & 1 & 1 & 1 & 1 & 1 \\
\hline ACA/CAG-206 & 1 & 1 & 1 & 1 & 1 & 1 & 1 & 1 & 0 & 1 & 1 \\
\hline ACA/CAG-211 & 1 & 1 & 1 & 1 & 1 & 1 & 1 & 1 & 1) & 1 & 1 \\
\hline $\mathrm{ACA} / \mathrm{CAG}-250$ & 1 & 1 & 1 & 1 & 1 & 1 & 1 & 1 & 1 & 1 & 1 \\
\hline $\mathrm{ACA} / \mathrm{CAG}-274$ & 1 & 1 & 1 & 1 & 1 & 1 & 1 & 1 & 1 & 0 & 1 \\
\hline ACA/CAG-286 & 1 & 1 & 1 & 1 & 1 & 1 & 1 & 1 & 1 & 1 & 1 \\
\hline $\mathrm{ACA} / \mathrm{CAG}-295$ & 1 & 1 & 1 & 1 & 1 & 1 & 1 & 1 & 1 & 1 & 1 \\
\hline $\mathrm{ACA} / \mathrm{CAG}-301$ & 1 & 1 & 1 & 1 & 1 & 1 & 1 & 1 & 1 & 1 & 1 \\
\hline $\mathrm{ACA} / \mathrm{CAG}-304$ & 1 & 0 & 0 & 1 & 0 & 0 & 1 & 11 & 1 & 1 & 0 \\
\hline $\mathrm{ACA} / \mathrm{CAG}-331$ & 1 & 1 & 0 & 1 & 0) & 0 & 1 & 1 & 1 & 1 & 1 \\
\hline $\mathrm{ACA} / \mathrm{CTC}-058$ & 1 & 1 & 1 & 1] & 11 & 1 & 1 & 1) & 1 & 1 & 1 \\
\hline $\mathrm{ACA} / \mathrm{CTC}-063$ & 0 & 0 & 1 & 0 & 1 & 1 & 0 & 0 & 0 & 0 & 1 \\
\hline ACA/CTC -065 & 1 & 0 & 1 & 1) & 1 & 1 & 1 & 0 & 0 & 0 & 0 \\
\hline $\mathrm{ACA} / \mathrm{CTC}-067$ & 0 & 0 & 0 & 0 & 0 & 0 & 0 & 0 & 0 & 0 & 0 \\
\hline ACA/CTC-070 & 1 & 1 & 1 & 1 & 11 & 1 & 1 & 1 & 1 & 1 & 1 \\
\hline $\mathrm{ACA} / \mathrm{CTC}-076$ & 0 & 0 & 0 & 0 & 0 & 0 & 0 & 0 & 0 & 0 & 0 \\
\hline ACA/CTC-098 & 0 & 0 & 0 & 0 & of & 0 & 0 & 0 & 0 & 0 & 0 \\
\hline ACA/CTC-100 & 1 & 1 & 0 & 1 & 0 & 1 & 1 & 1 & 1 & 1 & 1 \\
\hline ACA/CTC-102 & 1 & 1 & 1 & 1 & 1 & 1 & 1 & 1 & 1 & 1 & 1 \\
\hline ACA/CTC-106 & 1 & 1 & 0 & 1 & 0 & 1 & 1 & 1 & 1 & 1 & 1 \\
\hline $\mathrm{ACA} / \mathrm{CTC}-107$ & 1 & 0 & 1 & 0 & 1 & 1 & 0 & 0 & 0 & 1 & 1 \\
\hline $\mathrm{ACA} / \mathrm{CTC}-112$ & 1 & 1 & 1 & 1) & 1 & 1 & 1) & 1 & 1) & 0 & 1 \\
\hline ACA/CTC-113 & 0 & 0 & 0 & 0 & of & 1 & 0 & 1 & 11 & 1 & 1 \\
\hline $\mathrm{ACA} / \mathrm{CTC}-115$ & 1 & 1 & 1 & 1 & 1 & 1 & 1 & 1 & 1 & 1 & \\
\hline $\mathrm{ACA} / \mathrm{CTC}-116$ & 1 & 0 & 1 & 1 & 1 & 1 & 1 & 1 & 0 & 0 & 1 \\
\hline ACA/CTC-133 & 1 & 1 & 1 & 1 & 1 & 1 & 1 & 1 & 1 & 1 & 1 \\
\hline ACA/CTC-140 & 1 & 1 & 1 & 1 & 1 & 1 & 1 & 1 & 1 & 1 & 1 \\
\hline $\mathrm{ACA} / \mathrm{CTC}-156$ & 1 & 0 & 1 & 0 & 1 & 1 & 0 & 1 & 0 & 1) & 0 \\
\hline ACA/CTC-164 & 11 & 1 & 0 & 0 & 0 & 1 & 0 & 0 & 1 & 1) & 1 \\
\hline
\end{tabular}


Anexo 2 - Presença e ausência de 134 bandas de AFLP

(Continuação)

\begin{tabular}{|c|c|c|c|c|c|c|c|c|c|c|c|}
\hline Banda & DG115 & DG116 & DG118 & DG138 & DG117 & DG119 I & DG120 & DG121 & DG122 & DG123 & DG124 \\
\hline $\mathrm{ACA} / \mathrm{CTC}-171$ & 0 & 1 & 1 & 0 & 1 & 0 & 0 & 0 & 0 & 1 & 1 \\
\hline ACA/CTC-187 & 0 & 1 & 0 & 0 & 0 & 0 & 0 & 0 & 0 & 0 & 0 \\
\hline $\mathrm{ACA} / \mathrm{CTC}-192$ & 1 & 1 & 1 & 1 & 1 & 1 & 1 & 1 & 1 & 1 & 1 \\
\hline $\mathrm{ACA} / \mathrm{CTC}-201$ & 1 & 1 & 1 & 1 & 1 & I) & 1 & 1 & 1 & 1) & 1 \\
\hline $\mathrm{ACA} / \mathrm{CTC}-210$ & 1 & 요 & 1 & 1 & 1 & 1 & 0 & 1 & 1 & 1 & 1 \\
\hline $\mathrm{ACA} / \mathrm{CTC}-212$ & 0 & 0 & 0 & 0 & 0 & 0 & 0 & 0 & 0 & 0 & 0 \\
\hline $\mathrm{ACA} / \mathrm{CTC}-226$ & 0 & 0 & 0 & 0 & 0 & 0 & 0 & of & 0 & 0 & 1 \\
\hline $\mathrm{ACA} / \mathrm{CTC}-227$ & 0 & 0 & 0 & 0 & 0 & 0) & 0 & 0 & 0 & 0 & 0 \\
\hline $\mathrm{ACA} / \mathrm{CTC}-230$ & 0 & 요 & 0 & 1 & 0 & 0 & 1 & 0 & 0 & 1 & 0 \\
\hline $\mathrm{ACA} / \mathrm{CTC}-244$ & 0 & 0 & 0 & 0 & 0 & 0 & 0 & 이 & 0 & 0 & 0 \\
\hline $\mathrm{ACA} / \mathrm{CTC}-269$ & 1 & 1 & 1 & 1 & 1 & 요 & 1 & of & 0 & 1 & 1 \\
\hline $\mathrm{ACA} / \mathrm{CTC}-270$ & 0 & 0 & 0 & 1 & 0) & 0 & 0 & 0 & 0 & 요 & 0 \\
\hline $\mathrm{ACA} / \mathrm{CTC}-287$ & 1 & 1 & 1 & 1 & 1 & 1 & 1 & 1 & 1 & 1 & 1 \\
\hline $\mathrm{ACA} / \mathrm{CTC}-293$ & 0 & 0 & 0] & 0 & 0 & 이 & 0 & 0 & 0 & of & 0 \\
\hline ACA/CTC-296 & 요 & 요 & 0 & 0 & 0 & 0 & 0 & 1 & 0 & of & 1 \\
\hline ACA/CTC-309 & of & 0 & o) & 0 & 0 & 0 & 0 & 0 & 0 & 0 & 0 \\
\hline $\mathrm{ACA} / \mathrm{C} \mathrm{TC}-322$ & 1 & 1 & 1 & 1 & 1 & 1 & 1 & 1 & 1 & 1 & 11 \\
\hline $\mathrm{ACT} / \mathrm{CAC}-062$ & 1 & 1 & 1) & 1 & 1 & 1 & $1]$ & 1 & 1 & 1 & 1 \\
\hline $\mathrm{ACT} / \mathrm{CAC}-064$ & 0 & 0) & 0 & 0 & 0 & 0 & 0 & 0 & 0 & 0 & 0 \\
\hline $\mathrm{ACT} / \mathrm{CAC}-081$ & 0 & 0 & 1 & 0 & 1 & 1 & 0 & 0 & 0 & 0 & 1 \\
\hline $\mathrm{ACT} / \mathrm{CAC}-084$ & 1 & 1 & 1 & 1 & 1 & 1 & 1 & 1 & 1 & 1 & 1 \\
\hline ACT/CAC-089 & 아 & 0 & 0 & 0 & 요 & 0 & 0 & 0 & 0 & 0 & 0 \\
\hline $\mathrm{ACT} / \mathrm{CAC}-091$ & 1 & 1 & 0 & 1 & 0 & 0 & 1 & 0 & 1 & 1 & 0 \\
\hline $\mathrm{ACT} / \mathrm{CAC}-108$ & 이 & 이 & I) & 0 & 1 & 0 & 0 & 0 & 0 & 0 & 0 \\
\hline $\mathrm{ACT} / \mathrm{CAC}-110$ & 1 & 요 & 1 & 1 & 1 & 1 & 1 & 1 & 0 & 1 & 1 \\
\hline $\mathrm{ACT} / \mathrm{CAC}-116$ & 1 & 1 & 요 & 1 & 0 & 0 & 1 & 0 & 0 & 요 & 0 \\
\hline $\mathrm{ACT} / \mathrm{CAC}-118$ & 1 & 0 & 0 & 0 & 0 & 0 & 0 & 0 & 0 & 0 & 0 \\
\hline $\mathrm{ACT} / \mathrm{CAC}-120$ & 1 & 1 & 1 & 1 & 1 & 1 & 1 & 1 & 1 & 1 & 1 \\
\hline $\mathrm{ACT} / \mathrm{CAC}-124$ & 1 & 1 & 1 & 0 & 1 & 1 & 0 & 0 & 0 & 0 & 1 \\
\hline $\mathrm{ACT} / \mathrm{CAC}-127$ & 0 & 0 & 0 & 0 & 0 & 0 & 0 & 0 & 0 & 0 & 0 \\
\hline ACT/CAC-140 & 1 & 1 & 0 & 1 & 0 & 0 & 1 & 1 & 1 & 1 & 0 \\
\hline $\mathrm{ACT} / \mathrm{CAC}-143$ & 1 & 0 & 1 & 0 & 1 & 0 & 0 & 1 & 요 & of & 1 \\
\hline $\mathrm{ACT} / \mathrm{CAC}-164$ & 1 & 11 & 1 & 1 & 1 & 1 & 1 & 0 & 0 & 1 & 1 \\
\hline ACT/CAC-167 & 1 & i) & 1 & 1 & 1 & 1 & 1 & 1 & 1 & 1 & 1 \\
\hline $\mathrm{ACT} / \mathrm{CAC}-175$ & 0 & 0 & 1 & 0 & 1 & 1 & 0 & 1 & 0 & 0 & 0 \\
\hline ACT/CAC-188 & 0 & 0 & 요 & 0 & 0 & 1 & 0 & 0 & 0 & of & 1 \\
\hline ACT/CAC-189 & 1 & 1 & 1 & 1 & 1 & 1 & 1 & 1 & 1 & 1 & 1 \\
\hline $\mathrm{ACT} / \mathrm{CAC}-201$ & 0 & 0 & 0 & 1 & 0 & 0 & 1 & 0 & 1 & 1 & 0 \\
\hline $\mathrm{ACT} / \mathrm{CAC}-214$ & 1 & 0 & 0 & 0 & 0 & 0 & 요 & 0 & 0 & 1 & 0 \\
\hline $\mathrm{ACT} / \mathrm{CAC}-226$ & 1 & 0 & 1 & 1 & 1 & 1 & 1 & 1 & 1 & 1 & 1 \\
\hline $\mathrm{ACT} / \mathrm{CAC}-230$ & 0 & 0 & 0 & 0 & 0 & 0 & 0 & 0 & 0 & 0 & 0 \\
\hline $\mathrm{ACT} / \mathrm{CAC}-234$ & 1 & 1 & 0 & 1 & 요 & 1 & 1 & 1 & 1 & 1 & 1 \\
\hline ACT/CAC-276 & 1 & 1 & 1 & 1 & 1 & 1 & 1 & 1 & 1 & 1 & 1 \\
\hline $\mathrm{ACT} / \mathrm{CAC}-310$ & 1 & 1 & 1 & ]) & 1 & 1 & 1 & 1 & 1 & 1 & 1 \\
\hline $\mathrm{ACT} / \mathrm{CAC}-340$ & 0 & 0 & 0 & 1 & 0 & 0 & 1 & 0 & 0 & 0 & 0 \\
\hline $\mathrm{AGG} / \mathrm{CAA}-054$ & 1 & 1 & 1 & 1 & 1 & 1 & 1 & 1 & 1 & 1 & 1 \\
\hline $\mathrm{AGG} / \mathrm{CAA}-056$ & 0 & 0 & 0 & 0 & 0 & 0 & 0 & 1 & 0 & 0 & 0 \\
\hline AGG/CAA-057 & 0 & 0 & 0 & 1 & 0 & 0 & 1 & of & 1 & 1 & 0 \\
\hline AGG/CAA-060 & 1 & 1 & 1 & 1 & 1 & 1 & 1 & 1 & 1 & 1 & 1 \\
\hline AGG/CAA-065 & 0 & 0 & 0 & 요 & of & 0 & 0 & 14 & 1 & 0 & 0 \\
\hline AGG/CAA-070 & 14 & 1 & 1 & 1 & 1 & 1 & 1 & 14 & 1 & 1 & 1 \\
\hline $\mathrm{AGG} / \mathrm{CAA}-071$ & 1 & 1 & 11 & 0 & I & 1 & 0 & 0 & 0 & 0 & 0 \\
\hline
\end{tabular}


Anexo 2 - Presença e ausência de 134 bandas de AFLP

(Continuação)

\begin{tabular}{|c|c|c|c|c|c|c|c|c|c|c|c|}
\hline Banda & DG115 & DG116 & DG118 & DG138 & DG117 & DG119 & DG120 & DG121 I & DG122 & DG123 & DG124 \\
\hline AGG/CAA-072 & 1 & 1 & $\begin{array}{r}0 \\
\end{array}$ & 1 & 0 & 1 & 1 & 1 & 1 & I & 1 \\
\hline AGG/CAA-075 & 1 & 1 & 1 & 1 & 1 & 1 & $1]$ & 1 & 1 & 0 & 1 \\
\hline AGG/CAA-078 & 1 & 1 & 1 & 1 & 1 & 1 & 1 & 1 & 1 & 1 & 1 \\
\hline $\mathrm{AGG} / \mathrm{CAA}-079$ & 0 & 1 & 0 & 1 & 0 & 0 & 1 & 1 & 1 & 11 & 0 \\
\hline AGG/CAA-080 & 1 & 11 & 1 & 1 & 1 & 1 & 1 & 11 & 1 & 1 & 1 \\
\hline AGG/CAA-083 & 1 & 0 & of & 0 & 0 & 0 & 0 & 0 & 0 & 0 & 0 \\
\hline AGG/CAA-093 & 1 & 11 & 1 & 1 & 1 & 1 & 1 & 1 & 1 & 1 & 1 \\
\hline AGG/CAA-103 & 1 & 1 & 1 & ] & 1 & 1 & 1 & 1 & 1 & 1 & 1 \\
\hline AGG/CAA-109 & 0 & 0 & 0 & 1 & of & 0 & 1 & 1 & 1 & 0 & 0 \\
\hline AGG/CAA-125 & 1 & 1 & 1 & 1 & 1 & 1 & 1 & 11 & 1 & 1 & 1 \\
\hline AGG/CAA-131 & 0 & 0 & 0 & 0 & 0 & 0 & 0 & 0 & 0 & 0 & 0 \\
\hline AGG/CAA-134 & 1. & 0 & 0 & 1 & 0 & 1 & 1 & 1 & 1 & 1 & 1 \\
\hline AGG/CAA-141 & 0) & 0 & $1]$ & 0 & 1 & 1 & 0 & 1 & 0 & of & 1 \\
\hline AGG/CAA-142 & 0 & 0 & 1 & 0 & 1 & 1 & 0 & 0 & 0 & 0 & 0 \\
\hline $\mathrm{AGG} / \mathrm{CAA}-146$ & 11 & 1 & 1 & 1 & 1 & 1 & 1 & 1 & 1 & 1 & 1 \\
\hline AGG/CAA-149 & 1 & 1 & 1 & 1 & 1 & 1 & 1 & 1 & 1 & 1 & 1 \\
\hline AGG/CAA-152 & 1 & 1 & 1 & 1 & 1 & 1 & 1 & 1 & 1 & 1 & 1 \\
\hline AGG/CAA-163 & 0 & 0 & 0 & 0 & 0 & 0 & 0 & 0 & 이 & 0 & 0 \\
\hline AGG/CAA-173 & 1 & 1 & 1 & 1 & 1 & 1 & 1 & 1 & 1 & 1 & 1 \\
\hline AGG/CAA-181 & 1 & 0 & 0 & 0 & 0 & 1 & 0 & 0 & 0 & 0 & 0 \\
\hline AGG/CAA-203 & 1 & 1 & 1 & 1 & 1 & 1 & 1 & 1 & 1 & 1 & 1 \\
\hline AGG/CAA-205 & 0 & 0 & 0 & 0 & 0 & 0 & 0 & 0 & 0 & 0 & 0 \\
\hline AGG/CAA-209 & 1 & 1 & 1 & 1 & 1 & 1 & 1 & 1 & 1 & 1 & 1 \\
\hline AGG/CAA-210 & 1 & 1 & 1 & 1 & 1 & 1 & 1 & 1 & 1 & 1 & 1 \\
\hline AGG/CAA-216 & 0 & 1 & 1 & 1 & 1 & 1 & 1 & 0 & 요 & 0 & 0 \\
\hline AGG/CAA-265 & 1 & 1 & 0 & 1 & 0 & 1 & 1 & 0 & 0 & 0 & 1 \\
\hline AGG/CAA-285 & 1 & 1 & 1 & 1 & 1 & 1 & 1 & 1 & 1 & 1 & 1 \\
\hline AGG/CAA-315 & 1 & 0 & 0 & 1 & 0 & 0 & 1 & 0 & 1 & 0 & 1 \\
\hline AGG/CAA-327 & 1 & 1 & 1 & 1 & 1 & 1 & 1 & 1 & 1 & 1 & 1 \\
\hline $\mathrm{AGG} / \mathrm{CAA}-347$ & 1 & 1 & 1 & 1 & 1 & 1 & 1 & 1 & 1 & 11 & 1 \\
\hline
\end{tabular}


Anexo 2 - Presença e ausência de 134 bandas de AFLP (Continuação)

\begin{tabular}{|c|c|c|c|c|c|c|c|c|c|c|c|}
\hline Banda & DG125 & DG126 & DG127 & DG128 & DG129 & DG130 & DG131 & DG132 & DG133 & DG134 & DG137 \\
\hline ACA/CAG-051 & 0 & 0 & 1 & 0 & 1 & 0 & 0 & 0 & 1 & 1 & 1 \\
\hline $\mathrm{ACA} / \mathrm{CAG}-052$ & 0 & 0 & 0 & 0 & 0 & 0 & 0 & 0 & 0 & 0 & 0 \\
\hline $\mathrm{ACA} / \mathrm{CAG}-056$ & 1 & 0 & 1 & 1 & 0 & 1 & 1 & 1 & 1 & 1 & 1 \\
\hline $\mathrm{ACA} / \mathrm{CAG}-058$ & 0 & 0 & 0 & 1 & 0 & 1 & 1 & 1 & 0 & 0 & 0 \\
\hline $\mathrm{ACA} / \mathrm{CAG}-060$ & 11 & 1 & 1 & 1) & 1 & 1 & 1 & I & 1 & 1 & 1 \\
\hline $\mathrm{ACA} / \mathrm{CAG}-063$ & 1 & 1 & 1 & 1 & 1 & 1 & 1 & 1 & 14 & 1 & 1 \\
\hline ACA/CAG-066 & $1]$ & 1 & 1 & 1) & 1 & 1 & 1 & 1 & 0 & 1) & 0 \\
\hline $\mathrm{ACA} / \mathrm{CAG} 069$ & 1 & 1 & I & 1 & 1 & 1 & 1 & 1 & 1 & 1 & 1 \\
\hline $\mathrm{ACA} / \mathrm{CAG}-071$ & 0 & 1 & 1 & 1 & 1 & 1 & 1 & 1 & 1 & 1 & 1 \\
\hline $\mathrm{ACA} / \mathrm{CAG}-074$ & 1 & 1 & 1 & 1 & 1 & 1 & 1 & 1 & 1 & 11 & 1 \\
\hline $\mathrm{ACA} / \mathrm{CAG}-075$ & 1 & 1 & 1 & 1 & 1 & 1 & 1 & 1 & 1 & 1 & 1 \\
\hline $\mathrm{ACA} / \mathrm{CAG}-079$ & 1 & 1) & 1 & 1 & 1 & 1 & 1 & $1)$ & 1 & 1 & 1 \\
\hline $\mathrm{ACA} / \mathrm{CAG}-082$ & 1 & 1 & 1 & 1 & 1 & 1 & 1 & 1 & 1 & 1 & 1 \\
\hline $\mathrm{ACA} / \mathrm{CAG}-085$ & 1 & 1 & 1 & 1 & 1 & 1 & 1 & 1 & 1 & 1 & 1 \\
\hline $\mathrm{ACA} / \mathrm{CAG}-089$ & of & 1 & 1 & 1 & 1 & 1 & 1 & 1 & 1 & 1 & 1 \\
\hline $\mathrm{ACA} / \mathrm{CAG}=094$ & 1 & 1) & 1 & 1 & 1 & 1 & 1 & 1 & 1 & 1 & 1 \\
\hline $\mathrm{ACA} / \mathrm{CAG}-095$ & 1 & 0 & 이 & 요 & of & 0 & of & 0 & of & 0 & 0 \\
\hline $\mathrm{ACA} / \mathrm{CAG}-110$ & 1 & 1 & 1 & 1 & 1 & 1 & 1 & 1 & $1)$ & 1 & 1 \\
\hline $\mathrm{ACA} / \mathrm{CAG}-113$ & 1 & 1 & 1 & 11 & 1 & 1 & 1 & 1 & 1 & 1 & 1 \\
\hline $\mathrm{ACA} / \mathrm{CAG}-143$ & 0 & 1 & 1 & 1 & 1 & 1 & 1 & 1 & 1 & 1 & 1 \\
\hline ACA/CAG-156 & 1 & 0 & 0 & 0 & 0 & 0 & 0 & 0 & 0 & 1 & 0 \\
\hline $\mathrm{ACA} / \mathrm{CAG}-159$ & 1 & 1 & 1 & 1 & 1 & 1 & 11 & 1 & 1 & 1 & 1 \\
\hline $\mathrm{ACA} / \mathrm{CAG}-187$ & 1 & 1 & 1 & 1 & 1 & 1 & 1 & 1 & 1 & 1 & 1 \\
\hline $\mathrm{ACA} / \mathrm{CAG}-190$ & 1 & 1 & 1 & 1) & 1 & 1 & 1 & 1 & 1 & 1 & 1 \\
\hline $\mathrm{ACA} / \mathrm{CAG}-206$ & 11 & 1 & 1 & 1 & 1 & 1 & 1 & 1 & 1 & 1 & 1 \\
\hline $\mathrm{ACA} / \mathrm{CAG}-211$ & 1 & 1 & 1 & 1 & 1 & 1 & 1 & 1 & 1 & 1 & 1 \\
\hline $\mathrm{ACA} / \mathrm{CAG}-250$ & 1 & 1 & 1 & 1 & 1 & 1 & 1 & 1 & 1 & 1 & 1 \\
\hline $\mathrm{ACA} / \mathrm{CAG}-274$ & 1 & 1 & 1. & 11 & 1 & 14 & 1 & $1]$ & 1 & 1 & 1 \\
\hline $\mathrm{ACA} / \mathrm{CAG}-286$ & 1 & 1 & 1 & 1 & 1 & 1 & $1]$ & 1 & 1 & 1 & 1 \\
\hline $\mathrm{ACA} / \mathrm{CAG}-295$ & 1 & 1 & 1 & 1 & 1 & 1 & 1 & 1 & 1 & 1 & 1 \\
\hline $\mathrm{ACA} / \mathrm{CAG}-301$ & 1 & 1 & 1 & 1 & 1 & 1 & 1 & 1 & 1 & 1 & 1 \\
\hline ACA/CAG-304 & 0 & 1 & 1 & 요 & 1 & 1 & 0 & 1 & of & 11 & 1 \\
\hline $\mathrm{ACA} / \mathrm{CAG}-331$ & 0 & 의 & 1 & 1 & 1 & 1 & I) & 1 & 0 & 0 & 1 \\
\hline ACA/CTC-058 & 1 & 1 & 1 & 1 & 1 & 1 & 1 & 1 & $1)$ & 1 & 1 \\
\hline $\mathrm{ACA} / \mathrm{CTC}-063$ & 0 & 1 & 0 & 1 & 1 & 1 & 1 & 1 & 1 & 1 & 0 \\
\hline ACA/CTC-065 & 0 & 요 & 0 & 0 & 1 & 요 & 0 & 0 & 1 & of & 0 \\
\hline ACA/CTC-067 & 0 & 0 & 0 & 0 & 0 & 0 & 0 & of & 0 & 0 & 0 \\
\hline ACA/CTC- -070 & I & 1 & 1 & 1 & 1 & 1 & 1 & 1 & 1 & 1 & 1 \\
\hline ACA/CTC-076 & 1 & 요 & 0 & 0 & 0 & 0 & 0 & 0 & 1 & 1 & 1 \\
\hline ACA/CTC- 098 & 0 & 0 & 1 & 0 & 0 & 1 & 0 & 1 & 0 & 0 & 0 \\
\hline ACA/CTC 100 & 1 & 1 & 1 & 1 & 1 & 1 & 0 & 1 & 1 & 1 & 1 \\
\hline $\mathrm{ACA} / \mathrm{CTC}-102$ & 1 & 1 & 1 & 1 & 1 & 1 & 1 & 1 & 1 & 1 & 1 \\
\hline $\mathrm{ACA} / \mathrm{CTC}-106$ & 1 & 1 & 1 & 0 & 1 & 1 & 0 & 1 & 0 & 0 & 1 \\
\hline $\mathrm{ACA} / \mathrm{CTC}-107$ & 1 & of & 1 & 0 & 0 & 1 & 0 & 1 & 0 & 1 & 1 \\
\hline $\mathrm{ACA} / \mathrm{CTC}-112$ & 1) & 1) & 1 & 1 & 1 & 1 & 1 & 1 & 1 & 1 & 1 \\
\hline ACA/CTC-113 & 0 & 0 & 0 & 1 & 0 & 0 & 1 & 0 & 0 & 0 & 1 \\
\hline $\mathrm{ACA} / \mathrm{CTC}-115$ & 1) & 1 & 1) & 1 & 1) & 1 & 1 & 1 & 1 & 1 & 1 \\
\hline ACA/CTC-116 & 1 & 1 & 1 & 1 & 1 & 1 & 1 & 1 & 1 & 1 & 1 \\
\hline $\mathrm{ACA} / \mathrm{CTC}-133$ & 11 & 1 & 1 & 1) & 1 & 1 & 1 & 1 & 1 & 1 & 1 \\
\hline ACA/CTC-140 & 1 & 1 & 1 & 1 & 1 & 1 & 1 & 1 & 1 & 1 & 1 \\
\hline ACA/CTC-156 & 0 & 1 & 1 & 1 & 1 & 0 & 1 & 0 & 1 & 0 & 1 \\
\hline ACA/CTC-164 & 01 & 1 & 1 & 0 & 0 & 1 & 0 & 11 & 0 & 1 & 1 \\
\hline
\end{tabular}


Anexo 2 - Presença e ausência de 134 bandas de AFLP

(Continuacão)

\begin{tabular}{|c|c|c|c|c|c|c|c|c|c|c|c|}
\hline Banda & $D G 125$ & DG126 & $\mathrm{DG} 127$ & DG128 & DG129 & DG130 & DG131 & DG132 & DG133 & DG134 & DG137 \\
\hline ACA/CTC-171 & 0 & 0 & 0 & 1 & 11 & 0 & 1 & 0 & 0 & 0 & 0 \\
\hline ACA/CTC-187 & 0 & 0 & 0 & 0 & 0 & 1 & 0 & 1 & 0 & 0 & 0 \\
\hline $\mathrm{ACA} / \mathrm{CTC}-192$ & 1 & 1 & 1 & 11 & 1 & 1 & 1 & 1 & 1 & 1 & 1 \\
\hline $\mathrm{ACA} / \mathrm{CTC}-201$ & $1)$ & 1 & 1 & 1 & 1 & 1 & 1 & 1 & 1 & 1 & 1 \\
\hline $\mathrm{ACA} / \mathrm{CTC}-210$ & 1 & 1 & 1 & 1 & 0 & 1 & 1 & 1 & 1 & 1 & 1 \\
\hline $\mathrm{ACA} / \mathrm{CTC}-212$ & 0 & 0 & 0 & 0 & 0 & 0 & 0 & 0 & 0 & 1 & 0 \\
\hline $\mathrm{ACA} / \mathrm{C} T \mathrm{C}-226$ & 0 & 0 & 0 & 0 & 0 & 0 & 0 & 0 & 0 & 1 & 1 \\
\hline $\mathrm{ACA} / \mathrm{CTC}-227$ & 0 & 0 & 0 & 0 & 0 & 0 & 0 & 0 & 0 & 0 & 0 \\
\hline ACA/CTC-230 & 0 & 0 & 0 & 0 & 0 & 0 & 0 & 0 & 1 & 0 & 0 \\
\hline АCA/CTC-244 & 0 & 0 & 0 & 0 & 0 & 0 & 0 & 0 & 0 & 0 & 0 \\
\hline ACA/CTC-269 & 1 & 1 & 0 & 0 & 0 & 0 & 0 & 0 & 0 & 1 & 0 \\
\hline $\mathrm{ACA} / \mathrm{CTC}-270$ & 0 & 0 & 0 & 0 & 0 & 0 & 0 & 0 & 0 & 0 & 1 \\
\hline ACA/CTC-287 & $1)$ & 1 & 1 & 1 & 1 & 1 & 1 & 1 & 1 & 1 & 1 \\
\hline $\mathrm{ACA} / \mathrm{CTC}-293$ & 0 & 0 & 0 & 0 & 0 & 0 & 0 & 0 & 0 & 0 & 0 \\
\hline ACA/CTC-296 & 0 & 1 & 1 & 1 & 0 & 1 & 1 & 1 & 1 & 1 & 1 \\
\hline $\mathrm{ACA} / \mathrm{CTC}-309$ & 0 & 1 & 0 & 1 & 0 & 0 & 0 & 0 & 0 & 0 & 0 \\
\hline $\mathrm{ACA} / \mathrm{CTC}-322$ & 11 & 1 & 1 & 1 & 1 & 1 & 1 & 1 & 1 & 1 & 1 \\
\hline $\mathrm{ACT} / \mathrm{CAC}-062$ & 1 & 1 & 1 & 1 & 1 & 1 & 1 & 1 & 11 & 1 & 1 \\
\hline $\mathrm{ACT} / \mathrm{CAC}-064$ & 0 & 0 & 0 & 0 & 0 & 0 & 0 & 0 & 0 & 0 & 0 \\
\hline $\mathrm{ACT} / \mathrm{CAC}-081$ & 0 & $1]$ & 0 & 1 & 1 & 1 & 1 & 1 & 1 & 1 & 0 \\
\hline ACT/CAC-084 & 1 & 1 & 1 & 1 & 1 & 1 & 1 & 1 & I & 1 & 1 \\
\hline $\mathrm{ACT} / \mathrm{CAC}-089$ & 0 & 0 & 0 & 0 & 0 & 0 & 0 & 0 & 0 & 0 & 0 \\
\hline ACT/CAC-091 & 1 & 0 & 0 & 0 & 0 & 0 & 0 & 0 & 0 & 1 & 1 \\
\hline ACT/CAC-108 & 1 & 1 & 1 & 1 & 1 & 1 & 1 & 1 & 1 & 0 & 1 \\
\hline ACT/CAC-110 & 1 & 1 & II & 1 & 1 & 1 & 1 & 1 & 1 & 0 & 1 \\
\hline ACT/CAC-116 & 1 & 0 & 0 & 0 & 0 & 0 & 0 & 0 & 0 & 0 & 0 \\
\hline ACT/CAC-118 & 1 & 0 & 1 & 0 & 0 & 1 & 0 & 1 & 0 & 1 & 0 \\
\hline ACT/CAC-120 & 1 & 1 & 1 & 1 & 1 & 1 & 1 & 1 & 1 & 1 & 1 \\
\hline $\mathrm{ACT} / \mathrm{CAC}-124$ & 1 & 1 & 1 & 1 & 1 & 1 & 1 & 1 & 1 & 1 & 1 \\
\hline ACT/CAC-127 & 0 & 0 & 1 & 1 & 1 & 0 & 1 & 0 & 1 & 0 & 1 \\
\hline ACT/CAC-140 & 1 & 0 & 0 & 0 & 0 & 0 & 0 & 0 & 0 & 0 & 0 \\
\hline $\mathrm{ACT} / \mathrm{CAC}-143$ & 1 & 1 & 1 & 11 & 1 & 1 & 1 & 1 & 1 & 1 & 1 \\
\hline ACT/CAC-164 & 1 & 1 & 1 & 1 & 1 & 1 & 1 & 1. & 1 & 1 & 1 \\
\hline ACT/CAC-167 & 1 & 1 & 1 & 1 & 1 & 1 & 1 & 1 & 1 & 1) & 1 \\
\hline ACT/CAC-175 & 0 & $1)$ & 1 & 1 & 1 & 1 & 1 & 1 & 11 & 1 & 1 \\
\hline ACT/CAC-188 & 0 & 0 & 0 & 0 & 0 & 0 & 0 & 0 & 0 & 1 & 1 \\
\hline ACT/CAC-189 & 1 & 0 & 0 & 1 & 1 & 1 & 1 & 1 & 1 & 1 & 1 \\
\hline ACT/CAC-201 & 0 & 0 & 0 & 0 & 0 & 0 & 0 & 0 & 0 & 0 & 0 \\
\hline ACT/CAC-214 & 0 & 0 & 1 & 0 & 1 & 0 & 0 & 0 & 0 & 0 & 0 \\
\hline ACT/CAC-226 & 1 & 1 & 1 & 1 & 1 & 1 & 1 & 1 & 0 & 0 & 1 \\
\hline ACT/CAC-230 & 0 & 1 & 1 & 1 & 1 & 1 & 1 & 1 & 1 & 0 & 1 \\
\hline ACT/CAC-234 & 1 & 1 & 1 & 1 & 1 & 1 & 1 & 1 & 1 & 1 & 1 \\
\hline ACT/CAC-276 & 1 & 1 & 1 & 1 & 1 & 1 & 11 & 1 & 1 & 1 & 1 \\
\hline $\mathrm{ACT} / \mathrm{CAC}-310$ & 1 & 1 & 1 & 1 & 1 & 1 & 1 & 1 & 1 & 1 & 1 \\
\hline $\mathrm{ACT} / \mathrm{CAC}-340$ & 0 & 0 & 0 & 0 & 0 & 0 & 0 & 0 & 0 & 0 & 0 \\
\hline AGG/CAA-054 & 1 & 1 & 1 & 1 & 1 & 1 & 1 & 1 & 1 & 1 & 1 \\
\hline AGG/CAA 056 & 0 & 1 & 0 & 1 & 1 & 0 & 1 & 0 & 1 & 0 & 0 \\
\hline AGG/CAA-057 & 1 & 0 & 0 & 0 & 0 & 0 & 0 & 0 & 0 & 0 & 1 \\
\hline AGG/CAA-060 & 1 & 1 & 1 & 1 & 1 & 1 & 1 & 1 & 1 & 1 & 1 \\
\hline AGG/CAA-065 & 0 & 0 & 0 & 0 & 1 & 0 & 0 & 0 & 0 & 0 & 0 \\
\hline AGG/CAA-070 & 1 & 1 & 1 & $1)$ & 1 & 1 & 1 & 1 & 1 & 1 & 1 \\
\hline AGG/CAA-071 & 11 & 1 & 1 & 1 & 1 & 1 & 1 & 1 & 1 & 0 & 1 \\
\hline
\end{tabular}


Anexo 2 - Presença e ausência de 134 bandas de AFLP

(Continuação)

\begin{tabular}{|c|c|c|c|c|c|c|c|c|c|c|c|}
\hline Banda & DG125 & DG126 & DG127 & DG128 & DG129 & DG130 & DG131 & DG132 & DG133 & DG134 & DG137 \\
\hline AGG/CAA-072 & 1 & 0 & 1 & 1 & $\begin{array}{r}0 \\
\end{array}$ & 0 & 0 & 11 & 0 & I & 0 \\
\hline AGG/CAA-075 & 0 & 1 & 0 & 0 & 1 & 1 & 1 & 1 & 1 & 1 & 1 \\
\hline AGG/CAA-078 & 1 & 1 & 1 & 1 & 1 & 1 & 1 & 1 & 1 & 1 & 1 \\
\hline $\mathrm{AGG} / \mathrm{CAA}-079$ & 0 & 0 & 0 & 0 & 0 & 1 & 0 & 1 & 1 & 0 & 0 \\
\hline AGG/CAA-080 & 1 & 1 & 1 & 1 & 1 & 1 & 1 & 1 & 1 & 1 & 1 \\
\hline AGG/CAA-083 & 1 & 0 & 0 & 0 & 0 & 0 & 0 & 0 & 0 & 1) & 0 \\
\hline AGG/CAA-093 & 1 & 1) & 1 & 1 & 11 & 1 & 1 & 1 & 1 & 1 & 1 \\
\hline $\mathrm{AGG} / \mathrm{CAA}-103$ & 1 & 1) & 1 & 1 & 1 & 1 & 11 & 1 & 1 & 1 & 1 \\
\hline AGG/CAA-109 & 0 & 1 & 1 & 0 & 0 & 0 & 0 & 0 & 1 & 0 & 1 \\
\hline AGG/CAA-125 & 1 & 1 & 1 & 1 & 1 & 1 & 1 & 1 & 1 & 1 & 1 \\
\hline AGG/CAA-131 & 0 & 0 & 0 & 0 & 0 & 0 & 0 & 0 & 0 & 0 & 0 \\
\hline $\mathrm{AGG} / \mathrm{CAA}-134$ & 1 & 1 & 1) & 1 & 1 & 1 & 1 & 1 & 1 & 1 & 1 \\
\hline AGG/CAA-141 & 0 & 1] & 1 & 1 & 1 & 0 & 1 & 0 & 1 & 0 & 1 \\
\hline AGG/CAA-142 & 0 & 0 & 0 & 0 & 0 & 0 & 0 & 0 & 0 & 1 & 1 \\
\hline AGG/CAA-146 & 1 & 1 & 1 & 1 & 1 & 1 & 1 & 1 & 1 & 1 & 1 \\
\hline AGG/CAA-149 & 1 & 1 & 1 & 1 & 1 & 1 & 1 & 1 & 1 & 1 & 1 \\
\hline AGG/CAA-152 & 1 & 1 & 1 & 1 & 1 & 1 & 1 & 1) & 1 & 1 & 1 \\
\hline AGG/CAA-163 & 0 & 0 & 0 & 1 & 0 & 0 & 1 & 0 & 0 & 0 & 0 \\
\hline AGG/CAA-173 & 1 & 1 & 1 & 1 & 1 & 1 & 1 & 1 & 1 & 1 & 1 \\
\hline AGG/CAA-181 & 0 & 1 & 0 & 1 & 0 & 0 & 1 & 0 & 1 & 0 & 1 \\
\hline AGG/CAA-203 & 1 & 1 & 1 & 1 & 1 & 1 & 1 & 1 & 1 & 1 & 1 \\
\hline AGG/CAA-205 & 0 & 0 & 요 & 0 & 0 & 0 & 0 & 0 & 0 & 0 & 0 \\
\hline AGG/CAA-209 & 1 & 1 & of & 1 & 1 & 1 & 1 & 1 & 1 & 1 & 1 \\
\hline AGG/CAA-210 & 1 & 1 & 1 & 1 & 1 & 1 & 1 & 1 & 1 & 1 & 1 \\
\hline AGG/CAA-216 & 1 & 1 & 0 & 1 & 우 & 1 & 1 & 1 & 1 & 1 & 1 \\
\hline AGG/CAA-265 & 0 & 1 & 1 & 0 & 0 & 1 & 0 & 1 & 1 & 0 & 1 \\
\hline AGG/CAA-285 & 1 & 1 & 1 & 1 & 1 & 1 & 1 & 1 & 1 & 1 & 1 \\
\hline AGG/CAA-315 & 1 & 0 & 0 & 0 & 0 & 0 & 0 & 0 & 이 & 0 & 0 \\
\hline $\mathrm{AGG} / \mathrm{CAA}-327$ & 1 & 1 & 1 & 1 & 1 & 1 & 1 & 1 & 1 & 1 & \\
\hline $\mathrm{AGG} / \mathrm{CAA}-347$ & 1 & 1 & 1 & 1 & 1 & 11 & 1 & 1 & 1 & 11 & \\
\hline
\end{tabular}


Anexo 3 - Presença e ausência de 49 bandas de 11 microssatélites

\begin{tabular}{|c|c|c|c|c|c|c|c|c|c|c|c|}
\hline Banda & DG038 & DG039 & DG040 & DG0+1 & DG042 & DG043 II & DG044 & DG045 & DG046 & DG047 & DG048 \\
\hline GA136-144 & 0 & 0 & 0 & 0 & 0 & 1] & 0 & 0 & 0 & 0 & 0 \\
\hline GA136-150 & 0 & 1 & 0 & 0 & 1 & 0 & 1 & 1 & 1 & 0 & 0 \\
\hline GA136-152 & 0 & 0 & 0 & 0 & 0 & 0 & 0 & 0 & 0 & 0 & 0 \\
\hline GA136-154 & 1 & 1 & 0 & 0 & 0 & 0 & 0 & 0 & 0 & 0 & 0 \\
\hline GA136-156 & 0 & 0 & 0 & 0 & 1 & 의 & 0 & 0 & 11 & 1) & 1 \\
\hline GA136-158 & 1 & 0 & 1 & 1 & 0 & 1 & 0 & ] & 0 & 1 & 1 \\
\hline GA126-182 & 1 & 0 & 11 & I) & 0 & 0 & 1 & 1 & 1 & 1 & 1 \\
\hline GA126-184 & 0 & of & 0 & 0 & of & 0 & 0 & 1 & 0 & 0 & 0 \\
\hline GA126-188 & 0 & 1 & 0) & 0 & 0 & 0 & 1 & 0 & 0 & 1 & 1 \\
\hline GA126-190 & 0 & 0 & 0 & 0 & 0 & 0 & 0 & 0 & 0 & 이 & 0 \\
\hline GA126-212 & 1 & 0 & 0 & 0 & 1 & 1 & 0 & 0 & 0 & 0 & 0 \\
\hline GA126-219 & 0 & 1 & 0 & 0 & 1 & 0 & 0 & 0 & 0 & 0 & 0 \\
\hline GA012-137 & 0 & 11 & 1 & 1 & 1 & 1 & 1 & 1 & 1 & 1 & 1 \\
\hline GA012-145 & 1 & 1 & 0 & 0 & 0 & 0 & 0 & 0 & 0 & 1 & 0 \\
\hline GA012-147 & 0 & 0 & 0 & 0 & 0 & 1 & 0 & ] & 1 & 0 & 0 \\
\hline GA131-096 & 1 & of & 이 & 0 & 0) & 0 & 0 & 1 & 0 & 0 & 0 \\
\hline GA131-100 & 0 & 0 & 0 & 0 & 0 & 0 & 0 & 0 & 0 & 0 & 0 \\
\hline GA131-102 & 0 & 0 & 1 & 1) & 1 & 0 & 1 & 0 & 0 & 0 & 1 \\
\hline GA131-104 & 0 & 0 & 0 & 0 & 0 & 0 & 0 & 0 & 1 & 0 & 0 \\
\hline GA131-106 & 0 & 0 & 0 & 0 & 0 & 0 & 0 & 11 & 0 & 0 & 0 \\
\hline GA131-112 & 0 & 0 & 0 & 0 & 0 & 0 & 0 & 0 & 0 & of & 0 \\
\hline GA131-114 & 1 & 0 & 1 & 1 & 1 & 1 & 1 & 0 & 0 & 1 & 0 \\
\hline GA131-116 & 0 & 1 & 0 & 0 & o & 1 & 0 & 0 & 1 & 1 & 1 \\
\hline GA134-309 & 0 & 1 & 0 & 0 & 1 & 0 & 0 & 1 & 1 & 1 & 1 \\
\hline GA134-317 & 1 & 1 & 1 & 1 & 1 & 1 & 1 & 1 & 1 & 1 & 0 \\
\hline GA134-326 & 0 & 0 & 1 & 1 & 0 & 0 & 0 & 0 & 0 & 0 & 0 \\
\hline GA013-136 & 0 & 0 & 0 & 0 & 이 & 0 & 1 & 0 & 0 & 0 & 0 \\
\hline GA013-138 & 1 & 1 & 1 & 1 & 1 & 1 & 1 & 1 & 1 & 1 & 1 \\
\hline GA140-148 & 0 & 1 & 0 & 0 & 0 & 0 & 0 & 0 & 0 & 0 & 0 \\
\hline GA140-158 & 0 & 0 & of & 0 & 0 & 0 & 1 & 1 & 0 & 1 & 0 \\
\hline GA140-162 & 1 & 0 & 1 & 1 & 1 & 0 & 0 & 1 & 1 & 0 & 0 \\
\hline GA140-166 & 0 & 0 & 1 & 1 & 1 & 1 & 0 & 0 & 0 & 0 & 1 \\
\hline GA140-168 & 0 & 0 & 0 & 0 & 0 & 0 & 0 & 0 & 0 & 0 & 0 \\
\hline GA140-172 & 11 & 0 & 0 & 0 & 0 & 11 & 1 & 0 & 1 & 1 & 1 \\
\hline GA021-106 & 0 & 0 & 0 & 0 & 0 & 0 & 0 & 0 & 0 & 0 & 0 \\
\hline GA021-109 & 0 & 0 & 0 & 0 & 0 & 0 & 0 & 0 & 0 & 0 & 0 \\
\hline GA021-110 & 0 & 0 & 0 & 0 & 0 & 0 & 0 & 0 & 1 & 0 & 0 \\
\hline GA021-112 & 1 & 1 & 0 & 0 & 1 & 0 & 0 & 1 & 0 & 0 & 1 \\
\hline GA021-114 & 1 & 1 & 1 & 1 & 0 & 1 & 1 & 1 & 11 & 1 & 1 \\
\hline GA021-116 & 0 & 0 & 0 & 0 & 0 & 0 & 0 & 0 & 0 & 0 & 0 \\
\hline GAGG5-117 & 0 & 0 & 1 & 1 & 0 & 1 & 1 & 0 & 1 & 1 & 1 \\
\hline GAGG5-119 & 1 & 0 & 0 & 0 & 1 & 0 & 1 & 1 & 1 & 1 & 0 \\
\hline GAGG5-127 & 1 & 1 & 1 & 1 & 1 & 0 & 0 & 1) & 0 & 0 & 0 \\
\hline GA057.161 & 0 & 0 & 1 & 1 & 1 & 0 & 1 & 0 & 0 & 0 & 1 \\
\hline GA057-180 & 1 & 1 & 1 & 1 & 0 & 11 & 1 & 1 & 1 & 1 & 1 \\
\hline GA057-182 & 0 & 0 & 0 & 0 & 0 & 0 & 0 & 0 & 0 & 0 & 0 \\
\hline GA057-184 & 0 & 1 & 0 & 0 & 0 & 0 & 0 & 1 & 1 & 0 & 0 \\
\hline GA016-104 & 1 & 1 & 1 & 1 & 1 & 1 & 1 & 1) & II & 1 & \\
\hline GA016-114 & 0 & 0 & 01 & 0 & 0 & 01 & 1) & 11 & 0 & 0 & \\
\hline
\end{tabular}


Anexo 3 - Presença e ausência de 49 bandas de 11 microssatélites

(Continuação)

\begin{tabular}{|c|c|c|c|c|c|c|c|c|c|c|c|}
\hline Banda & DG049 & DG050 & DG051 & DG052 & DG054 & DG055 & DG056 & DG058 & DG059 & DG060 & DG061 \\
\hline GA136-144 & 0 & 0 & 1 & 1 & 0 & 0 & 0 & 0 & 0 & 0 & 0 \\
\hline GA136-150 & 0) & 1 & 0 & 0 & 0 & 0 & 1 & 0 & 0 & 1 & 1 \\
\hline GA136-152 & 0 & () & 0 & 0 & 0 & 0 & 0 & 0 & 0 & 0 & 0 \\
\hline GA136-154 & 1 & 0 & 0 & of & 0 & 1 & 0 & 0 & 11 & 0 & 0 \\
\hline GA136-156 & 1 & 0 & 0 & 0 & 1 & 1 & 0 & 1 & 1 & 1 & 0 \\
\hline GA136-158 & 0 & 1 & 1 & 1 & 1 & 0 & 1 & 1) & 0 & 0 & 1 \\
\hline GA126-182 & 1 & 1 & 0 & 1 & 0 & 0 & 1 & 1 & 1 & 1 & 1 \\
\hline GA126-184 & 0 & 0 & 0 & 0 & 0 & 0 & 0 & 0 & 0 & 0 & 1 \\
\hline GA126-188 & 0 & 0 & 0 & 0 & 1 & 1 & 1 & 0 & 0 & 0 & 0 \\
\hline GA126-190 & 0 & 0 & 0 & 0 & 0 & 0 & 0 & 0 & 0 & 0 & 0 \\
\hline GA126-212 & 1 & 1 & 1 & 1 & 1 & 1 & 0 & 0 & 1 & 0 & 0 \\
\hline GA126-219 & 0 & 0 & 0 & 0 & 0 & 0 & 0 & 0 & 0 & 0 & 0 \\
\hline GA012-137 & 1 & 1 & 1 & 1 & 1 & 1 & 1 & 1 & 1 & 1 & 1 \\
\hline GAO12-145 & 0 & 0 & 0 & 0 & 0 & 1 & 0 & 1 & 0 & 1 & 0 \\
\hline GA012-147 & 0 & 0 & 1 & 1 & 1 & 0 & 1 & 0 & 0 & 0 & 1 \\
\hline GA131-096 & 0 & 0 & 0 & 0 & 0 & 0 & 0 & 0 & 0 & 0 & 1 \\
\hline GA131-100 & 0 & 0 & 0 & 0 & 1 & - & 0 & 0 & 0 & 0 & 0 \\
\hline GA131-102 & 0 & 0 & 0 & 0 & 0 & 0 & 0 & 0 & 0 & 1 & 0 \\
\hline GA131-104 & 0 & 0 & 0 & 1 & 0 & 0 & 1 & 0 & 0 & 0 & 0 \\
\hline GA131-106 & 0 & 0 & 0 & 0 & 0 & 0 & 0 & 0 & o & 0 & 1 \\
\hline GA131-112 & 0 & 0 & 0 & 0 & 0 & 0 & 0 & 0 & 0 & 0 & 0 \\
\hline GA131-114 & 1 & 1 & 1 & 0 & 0 & 1 & 0 & 1 & 1 & 0 & 0 \\
\hline GA131-116 & 1 & 0 & 1 & 1 & 1 & 1 & 1 & 1 & 1 & 1 & 0 \\
\hline GA134-309 & 1 & 1 & 0 & 1 & 0 & 0 & 1 & 0 & 1 & 0 & 1 \\
\hline GA134-317 & 0 & 1 & 1 & 1 & 1 & 1 & 1 & 1 & 0 & 1 & 1 \\
\hline GA134-326 & 0 & 0 & 0 & 0 & 1 & 0 & 0 & 0 & 0 & 0 & 0 \\
\hline GA013-136 & 0 & 0 & 0 & 0 & 0 & 0 & 0 & 0 & 0 & 0 & 0 \\
\hline GA013-138 & 1 & 11 & 1 & 1 & 1 & 1 & 1 & 1 & 1 & 1 & 1 \\
\hline GA140-148 & 0 & 0 & 0 & 0 & 0 & 0 & 0 & 0 & 0 & 0 & 0 \\
\hline GA140-158 & 1 & 1 & 0 & 0 & 0 & 1 & 0 & 1 & 1 & 1 & 1 \\
\hline GA140-162 & 0 & 1 & 0 & 0 & 0 & 0 & 0 & 0 & 0 & 0 & 1 \\
\hline GA140-166 & 0 & 0 & 1 & 0 & 1 & 0 & 0 & 0 & 0 & 0 & 0 \\
\hline GA140-168 & 0 & 0 & 0 & 0 & 0 & 0 & 0 & 0 & 0 & 0 & 0 \\
\hline GA140-172 & $1)$ & 0 & 1 & 1) & o) & 1 & 1 & 1 & 1 & 1 & 0 \\
\hline GA021-106 & 0 & 0 & 0 & 0 & 0 & 0 & 0 & 0 & 0 & 0 & 0 \\
\hline GA021-109 & 0 & 0 & 0 & 0 & 0 & 1 & 0 & 0 & 0 & 0 & 0 \\
\hline GA021-110 & 0 & 0 & 0 & 1 & 0 & 0 & 0 & 0 & 0 & 1 & 0 \\
\hline GA021-112 & 0 & 0 & 0 & 0 & 1 & 0 & 0 & 0 & 0 & 0 & 1 \\
\hline GA021-114 & 1 & 1 & 1 & 1 & 1 & 1) & 1 & 1 & 1 & 1 & 1 \\
\hline GA021-116 & 0 & 0 & 0 & 0 & 0) & 0 & 0 & 0 & 0 & 0 & 0 \\
\hline GAGG5-117 & 1 & 1 & 1 & 1 & 1 & 1 & 0 & 1) & 1 & 1) & 0 \\
\hline GAGG5-119 & 0 & 0 & 0 & 1 & 0 & 0 & 1 & 0 & 0 & 1 & 1 \\
\hline GAGG5-127 & 0 & 0 & 0 & 0 & 0 & 0 & 0 & 0 & 0 & 0 & 1 \\
\hline GA057-161 & 0 & 0 & 0 & 0 & 0 & 0 & 0 & 0 & 0 & 0 & 0 \\
\hline GA057-180 & 1) & 1 & 1 & 1 & 1 & 1 & 1 & 1 & 1 & 1 & 1 \\
\hline GA057-182 & 0 & 0 & 0 & 0 & 0 & 0 & 0 & 1 & 0 & 0 & 0 \\
\hline GA057-184 & 0 & 0 & 0 & 0 & 0 & 0 & 0 & 0 & 0 & 0 & 1 \\
\hline GA016-104 & 1 & 1 & 1 & 1 & 1) & 1 & 1 & 1 & 1 & 1 & 1 \\
\hline GA016-114 & 1 & 11 & 0 & 0 & 0 & 0 & 0 & 0 & 1 & 0 & 1 \\
\hline
\end{tabular}


Anexo 3 - Presença e ausência de 49 bandas de 11 microssatélites

(Continuação)

\begin{tabular}{|c|c|c|c|c|c|c|c|c|c|c|c|}
\hline Banda & DG062 & DG065 & DG067 & DG068 & DG069 & DG070 & DG073 & DG111 & DG112 & DG113 & DG114 \\
\hline GA136-144 & 0 & 0 & 0 & 0 & 0 & 0 & 0 & 0 & 0 & 0 & 0 \\
\hline GA136-150 & 0 & 1 & 0 & 1 & 0 & 1 & 0 & 1 & 0 & 1 & 1 \\
\hline GA136-152 & 0 & 0 & 0 & 0 & 0) & 0 & 0 & 0 & 0 & 0 & 0 \\
\hline GA136-154 & 0 & 1 & 1 & 0 & 1 & 0 & 0 & 0 & 1 & 0 & 0 \\
\hline GA136-156 & 1 & 0 & 0 & 0 & 0 & 0 & 0 & 0 & 0 & 0 & 0 \\
\hline GA136-158 & 1 & 0 & 1 & 1 & 1 & 1 & 1 & 1 & 1 & 1 & 1 \\
\hline GA126-182 & 1 & 1 & 1 & 1 & 11 & 1 & 1 & 1 & 1 & 1 & 1 \\
\hline GA126-184 & 0 & 0 & 0 & 1 & 0 & 0 & 0 & 0 & 0 & 0 & 0 \\
\hline GA126-188 & 0 & 1 & 0 & 0 & 0 & 0 & 0 & 0 & 0 & 0 & 1 \\
\hline GA126-190 & 0 & 0 & 0 & 0 & 0 & 0 & 0 & 0 & 0 & 0 & 0 \\
\hline GA126-212 & 0 & 0 & 0 & 0 & 0 & 0 & 0 & 0 & 1 & 0 & 0 \\
\hline GA126-219 & 0 & 0 & 1 & 0 & 0 & 0 & 0 & 0 & 0 & 0 & 0 \\
\hline GA012-137 & 11 & 0 & 0 & 1 & 1 & 1 & 0 & 1 & 0 & 1 & 1 \\
\hline GA012-145 & 1 & 1 & 0 & 0 & 0 & 1 & 1 & 1 & 1 & 1 & 0 \\
\hline GA012-147 & 0 & 0 & 1 & 1 & 0 & 0 & 1 & 0 & 0 & 0 & 0 \\
\hline GA131-096 & 0 & 0 & 1 & 1 & 0 & 1 & 0 & 0 & 1 & 1 & 0 \\
\hline GA131-100 & 0 & 0 & 0 & 0 & 0 & 0 & 0 & 0 & 0 & 0 & 0 \\
\hline GA131-102 & 0 & 0 & 0 & 0 & 0 & 0 & 0 & 1 & 0 & 0 & 1 \\
\hline GA131-104 & 0 & 0 & 0 & 0 & 0 & 0 & 0 & 0 & 0 & 0 & 0 \\
\hline GA131-106 & 0 & 1 & 0 & 1 & 0 & 0 & 0 & 0 & 0 & 0 & 0 \\
\hline GA131-112 & 0 & 0 & 0 & 0 & 1 & 0 & 0 & 0 & 0 & 0 & 0 \\
\hline GA131-114 & 1 & 0 & 0 & 0 & 1 & 0 & 1 & 1 & 1 & 1 & 0 \\
\hline GA131-116 & 1 & 1 & 0 & 0 & 0 & 1 & 1 & 0 & 0 & 0 & 1 \\
\hline GA134-309 & 0 & 0 & 1 & 1 & 0 & 0 & 1 & 0 & 0 & 0 & 0 \\
\hline GA134-317 & 1 & 1 & 1 & 1 & 1 & 1 & 1 & 1 & 1 & 1 & 1 \\
\hline GA134-326 & 0 & 0 & 0 & 0 & 0 & 0 & 0 & 0 & 0 & 0 & 0 \\
\hline GA013-136 & 0 & 0 & 0 & 0 & 0 & 0 & 0 & 0 & 0 & 0 & 0 \\
\hline GA013-138 & 1 & 1 & 1 & 1 & 1 & 1 & 1 & 1 & 1 & 1 & 1 \\
\hline GA140-148 & 0 & 1 & 0 & 0 & 0 & 0 & 0 & 0 & 0 & 0 & 0 \\
\hline GA140-158 & 1 & 0 & 0 & 1 & 0 & 1 & 0 & 0 & 0 & 0 & 0 \\
\hline GA140-162 & 0 & 0 & 1 & 1 & 1 & 0 & 0 & 1 & 1 & 1 & 1 \\
\hline GA140-166 & 0 & 0 & 1 & 0 & 0 & 0 & 0 & 0 & 0 & 0 & 0 \\
\hline GA140-168 & 0 & 0 & 0 & 0 & 1 & 0 & 1 & 0 & 0 & 0 & 0 \\
\hline GA140-172 & 1 & 0 & 0 & 0 & 0 & 0 & 0 & 1 & 1 & 1) & 1 \\
\hline GA021-106 & 0 & 0 & 0 & 0 & 1 & 1 & 1 & 0 & 0 & 0 & 0 \\
\hline GA021-109 & 0 & 0 & 0 & 0 & 0 & 0 & 0 & 0 & 0 & 0 & 0 \\
\hline GA021-110 & 0 & 0 & 0 & 0 & 0 & 0 & 0 & 0 & 0 & 0 & 0 \\
\hline GA021-112 & 0 & 0 & 1 & 1 & 0 & 0 & 0 & 1 & 1 & 0 & 0 \\
\hline GA021-114 & 1 & 0 & 0 & 1 & 1 & 1 & 1 & 0 & 1 & 1 & 1 \\
\hline GA021-116 & 0 & 1 & 0 & 0 & 0 & 0 & 0 & 0 & 0 & 0 & 0 \\
\hline GAGG5-117 & 1 & 1 & 1 & 0 & 1 & 1 & 1 & 1 & 0 & 1 & 1 \\
\hline GAGG5-119 & 0 & 0 & 0 & 1 & 1 & 0 & 0 & 0 & 1 & 요 & 0 \\
\hline GAGG5-127 & 0 & 0 & 1 & 1 & 0 & 0 & 0 & 0 & 1 & 0 & 0 \\
\hline GA057-161 & 0 & 0 & 1 & 0 & 0 & 1 & 1 & 0 & 0 & 0 & 0 \\
\hline GA057-180 & 1 & 0 & 0 & 1 & 1 & 1 & 1 & 1 & 1 & 1 & 1 \\
\hline GA057-182 & 1 & 0 & 0 & 0 & 0 & 0 & 0 & 0 & 0 & 0 & 0 \\
\hline GA057-184 & 0 & 1 & 1 & 1 & 0 & 0 & 0 & 0 & 0 & 1 & 0 \\
\hline GA016-104 & 11 & 1 & 0 & 1 & 1 & 1 & 1 & 1 & 1 & 1 & 1 \\
\hline GA016-114 & 0 & 0 & 1 & 1) & 1 & 0 & 0 & 1 & 0 & 0 & \\
\hline
\end{tabular}


Anexo 3 - Presença e ausência de $\$ 9$ bandas de 11 microssatélites

(Continuação)

\begin{tabular}{|c|c|c|c|c|c|c|c|c|c|c|c|}
\hline Banda & DG115 & DG116 & DG118 & DG138 & DG117 & DG119 & $\mathrm{DG} 120$ & $\mathrm{DG} 121$ & DG122 & DG123 & DG124 \\
\hline GA136-144 & of & 0 & 0 & 0 & 0 & 0 & 0 & 1 & 0 & 1 & 0 \\
\hline GA136-150 & 0 & 0 & 1 & 0 & 1 & 0 & 0 & 0 & 1 & 0 & 0 \\
\hline GA136-152 & 1 & 0 & 0 & 0 & 0 & 0 & 0 & 0) & 0 & 0 & 0 \\
\hline GA136-154 & 0 & 1 & 0 & 11 & 0 & 1 & 1 & 0 & I) & 1 & 1 \\
\hline GA136-156 & 0 & 0) & 0 & 0 & 0 & 0 & 0 & 0 & 0 & 0 & 0 \\
\hline GA136-158 & 1 & 0 & 1 & 1 & 1 & 1 & 1 & 1 & 0 & 0 & 1 \\
\hline GA126-182 & 1 & 1 & 1 & 1 & 1 & 1 & 1 & 1 & 1 & 1 & 1 \\
\hline GA126-184 & 0 & 0 & 0 & of & of & 0 & 0 & 0 & 0 & 0 & 1 \\
\hline GA126-188 & 0 & 0 & 0 & 1 & 0 & 0 & 1 & 0 & 1 & 0 & 0 \\
\hline GA126-190 & 0 & 0 & 0 & 0 & 0 & 0 & 0 & 0 & 0 & 0 & 0 \\
\hline GA126-212 & 0 & 0 & 0 & 0 & 0 & 0 & 0 & 0 & 0 & 0 & 0 \\
\hline GA126-219 & 1 & 0 & 1 & 0 & 1 & 1 & 0) & 1 & 0 & 1 & 0 \\
\hline GA012-137 & 1 & 1 & 1 & 1 & 1 & 1 & 1 & 1 & 1 & 요 & 1 \\
\hline GA012-145 & 1 & 1 & 0 & 0 & 0 & 0 & 0 & 1 & 0 & 0 & 0 \\
\hline GA012-147 & 0 & 0 & 0 & 0 & 0 & 1 & 0 & 0 & 1 & 1 & 1 \\
\hline GA131-096 & 1 & 1 & 1 & 1 & 1 & 1 & 1 & 1 & 0 & 0 & 0 \\
\hline GA131-100 & 0 & 0 & 0 & 0 & 0 & 0 & 0 & 0 & 0 & 0 & 0 \\
\hline GA131-102 & 0 & 0 & 0 & 1 & 0 & 0 & 1 & 0 & 0 & 0 & 0 \\
\hline GA131-104 & 0 & 0 & 0 & 0 & 0 & 0 & 0 & 0 & 0 & 0 & 0 \\
\hline GA131-106 & 0 & 이 & 0 & 0 & 0 & 1 & 0 & 0 & 0 & 0 & 1 \\
\hline GA131-112 & 0 & 0 & 0 & 0 & 0 & 0 & 0 & 0 & 0 & 0 & 0 \\
\hline GA131-114 & 0 & 0 & 0 & 0 & 0 & 0 & 0 & 0 & 1 & 1 & 0 \\
\hline GA131-116 & 1 & 1 & 1 & 0 & 1 & 0 & 0 & 1 & 0 & 11 & 0 \\
\hline GA134-309 & 0 & 0 & 0 & 0 & 0 & 1 & 0 & 0 & 0 & 0 & 0 \\
\hline GA134-317 & 1 & 1 & 1 & 1 & 1 & 1 & 1 & 1 & 1 & 1 & 1 \\
\hline GA134-326 & 0 & 0 & 0 & 0 & 0 & 0 & 0 & 0 & 0 & 0 & 0 \\
\hline GA013-136 & 0 & 0 & 0 & 0 & 0 & 0 & 0 & 0 & 0 & 0 & 0 \\
\hline GA013-138 & 1 & 1 & 1 & 1 & 1 & 1 & 1 & 1 & 1 & 1 & 1 \\
\hline GA140-148 & 요 & of & 0 & 0 & 0 & 0 & 0 & 0 & 0 & 0 & 0 \\
\hline GA140-158 & 0 & 1 & of & 0 & o) & 0 & 0 & 0 & 요 & 이 & 0 \\
\hline GA140-162 & 0 & o & 1 & 1 & 1 & 1 & 1 & 0 & 1 & 0 & 1 \\
\hline GA140-166 & 0 & 1 & 0 & 0 & of & 0 & 0 & 0 & 0 & 1 & 0 \\
\hline GA140-168 & 1 & 0 & 1 & 0 & 1 & 1 & 0 & 1 & 0 & 1 & 0 \\
\hline GA140-172 & 1 & 0 & 0 & 1 & 0 & 0 & 1 & 1 & 0 & 0 & 0 \\
\hline GA021-106 & 0 & 0 & 0 & 0 & 0 & 0 & 0 & 0 & 0 & 0 & 0 \\
\hline GA021-109 & 0 & 0 & 의 & 0 & 0 & 0 & 0 & 0 & 요 & 0 & 0 \\
\hline GA021-110 & 0 & 0 & 이 & 0 & 0 & 0 & 0 & 0 & 0 & 0 & 0 \\
\hline GA021-112 & 0 & 0 & 1 & 0 & 1 & 1 & 0 & 0 & 0 & 1 & 1 \\
\hline GA021-114 & 1 & 1 & 이 & 1 & o & 1 & 1 & 1 & 1 & 1 & 0 \\
\hline GA021-116 & 0 & 0 & 0 & 0 & 0 & 0 & 0 & 0 & 0 & 0 & 0 \\
\hline GAGG5-117 & 1 & 0 & of & 1 & 0 & 1 & 1 & 1 & 1 & 1 & 1 \\
\hline GAGG5-119 & 0) & 0 & 요 & 0 & 0 & 0 & 0 & 0 & 0 & 0 & 0 \\
\hline GAGG5-127 & 1 & 1 & 1 & 0 & 1 & 1 & 0 & 0 & 0 & 1 & 1 \\
\hline GA057-161 & 1 & 0 & 1 & 1 & 1 & 11 & 1 & 1 & 0 & 1 & 1 \\
\hline GA057-180 & 1 & $1)$ & 1 & 1 & 1 & 0 & 1 & 0 & 1 & 1 & 0 \\
\hline GA057-182 & 0 & 0 & 0 & 0 & 0 & 0 & 0 & 1 & 0 & 0 & 0 \\
\hline GA057-184 & 0 & 0 & 이 & 0 & 0 & 0 & 0 & 0 & 0 & of & 1 \\
\hline GA016-104 & 1 & 1 & 1 & 1 & 1 & 1 & 1 & 1 & 1 & 1 & 1 \\
\hline GA016-114 & 0 & 0 & 11 & 0 & 1 & 1 & 1 & 0 & 0 & 01 & 0 \\
\hline
\end{tabular}


Anexo 3 - Presença e ausência de 49 bandas de 11 microssatélites

(Continuação)

\begin{tabular}{|c|c|c|c|c|c|c|c|c|c|c|c|}
\hline Banda & DG125 & DG126 & DG127 & DG128 & DG129 & DG130 & DG131 & DG132 & DG133 & DG134 & DG137 \\
\hline GA136-144 & 0 & of & 0 & 0 & 0 & 0 & 0 & 0 & 0 & 0 & 0 \\
\hline GA136-150 & 0 & 1 & 1 & 1 & 1 & 11 & $1)$ & 1 & 1 & 1 & 1 \\
\hline GA136-152 & of & 이 & 0 & 0 & of & 0 & 0 & 0 & 0 & 이 & 0 \\
\hline GA136-154 & 0 & 0 & 0 & 요 & 1 & 0 & 0 & 0 & 0 & 0 & 1 \\
\hline GA136-156 & 0 & 0 & 0 & 0 & 0 & 0 & 0 & 0 & 0 & 0 & 0 \\
\hline GA136-158 & 1 & 1 & 0 & 1 & 0 & 1 & 1 & 1 & 1) & 1 & 0 \\
\hline GA126-182 & 1 & 0 & 0 & 0 & o & 1 & 0 & 11 & 0 & 1 & 1 \\
\hline GA126-184 & 0 & 1 & 1 & 요 & 1 & 1 & 의 & 1 & 1 & 0 & 0 \\
\hline GA126-188 & of & 0 & 0 & 1 & 요 & 요 & 1 & 0 & 1 & 0 & 0 \\
\hline GA126-190 & 1 & 0 & 0 & 0 & 0 & 0 & 0 & 0 & 0 & 0 & 0 \\
\hline GA126-212 & 0 & 1 & 1 & 0 & 1 & 0 & 0 & 0 & 요 & of & 1 \\
\hline GA126-219 & 0 & 0 & 요 & 1 & 0 & of & 1 & 요 & 0 & 0 & 0 \\
\hline GA012-137 & 0 & 0 & 요 & 1 & 1 & 1 & 1 & 1 & 1 & 1 & 1 \\
\hline GA012-145 & 1 & 1 & 1 & 1 & 1 & 1 & 1 & 1 & 1 & 0 & 1 \\
\hline GA012-147 & 0 & 0 & 0 & 0 & 0 & 0 & 0 & 0 & 0 & 1 & 0 \\
\hline GA131-096 & 0 & 이 & 0 & 11 & 1 & 11 & 1 & 1 & 1 & 0 & 0 \\
\hline GA131-100 & 0 & 0 & 0 & 0 & 0 & 0 & of & of & 0 & 0 & 0 \\
\hline GA131-102 & 0 & 0 & 0 & 0 & 0 & 0 & 0 & 0 & 0 & 0 & 0 \\
\hline GA131-104 & 0 & 0 & 요 & 0 & 0 & 0 & 0 & 0 & 0 & 0 & 0 \\
\hline GA131-106 & 1 & 1 & 1 & 이 & 요 & 1 & 요 & 1 & 0 & 1 & 1 \\
\hline GA131-112 & 0 & 0 & 의 & 0 & o & 0 & 0 & 0 & 0 & 0 & 0 \\
\hline GA131-114 & 0 & 0 & 0 & 요 & 0 & 0 & 0 & 0 & 0 & 0 & 0 \\
\hline GA131-116 & 1 & 1 & 1 & 1 & 1 & 0 & 1 & 아 & 1 & 1 & 1 \\
\hline GA134-309 & 0 & 1 & 0 & 0 & 0 & 1 & 0 & 1 & 1 & 1 & 0 \\
\hline GA134-317 & 1 & 1 & 1 & 1 & 1 & 1 & 1 & 1 & 1 & 1 & 1. \\
\hline GA134-326 & 0 & 0 & 0 & 0 & 0 & 0 & 0 & 0) & 0 & 요 & 0 \\
\hline GA013-136 & 0 & 0 & 0 & 0 & 0 & 0 & 0 & 0 & 0 & 0 & 0 \\
\hline GA013-138 & 1 & 1 & 1 & 1 & 1 & 1 & 1 & 1 & 1 & 1 & 1 \\
\hline GA140-148 & 0 & 1 & 0 & 1 & 0 & 0 & 1 & 이 & 1 & 0 & 1 \\
\hline GA140-158 & 1 & 0 & 0 & 이 & 0 & 1 & 0 & 1 & 0 & 1 & 0 \\
\hline GA140-162 & 0 & 1 & 1 & 1 & 1 & 1 & 1 & 1 & 1 & 1 & 1 \\
\hline GA140-166 & 1 & 0 & 0 & 0 & 0 & 0 & 0 & 0 & 0 & 0 & 0 \\
\hline GA140-168 & 0 & 0 & 11 & 0 & 1 & 0 & 0 & 0 & 요 & 0 & 0 \\
\hline GA140-172 & 이 & 0 & 이 & 0 & of & 0 & 0 & 0 & 0 & 0 & 0 \\
\hline GA021-106 & 요 & 0 & 0 & 0 & 0 & 요 & 의 & 0 & 0 & 0 & 0 \\
\hline GA021-109 & 요 & 0 & 0 & 0 & 0 & of & 0 & 0 & 0 & 0 & 0 \\
\hline GA021-110 & 0 & 0 & 0 & 0 & 0 & 0 & 0 & 0 & 0 & 0 & 0 \\
\hline GA021-112 & 요 & 1 & 1 & 1 & 0 & 1 & 1 & 1) & 0 & 1 & 1 \\
\hline GA021-114 & 1 & 1 & 0) & 요 & 1 & of & 0 & 이 & 1 & 0 & 0 \\
\hline GA021-116 & 0 & 요 & 1 & 11 & 1 & 1 & 1 & 1 & 1 & 1 & 1 \\
\hline GAGG5-117 & 0 & 1 & 1 & 1 & 1 & 0 & 1 & 0 & 1 & 1 & 1 \\
\hline GAGG5-119 & 0) & 요 & 요 & 0 & 요 & 0 & 요 & of & 요 & 0 & 0 \\
\hline GAGG5-127 & 1 & 1 & 1) & 1 & 1 & 1 & 1 & 1 & 1 & 1 & 0 \\
\hline GA057-161 & 1 & 0 & 0 & 1 & 0 & 0 & 1 & of & 1 & 0 & 0 \\
\hline GA057-180 & 의 & 0 & 1 & 1 & 0 & 1 & 1 & 1 & 1 & 1 & 1 \\
\hline GA057-182 & 0 & 0 & 0 & 0 & 0 & 0 & 0 & 0 & 0 & 0 & 0 \\
\hline GA057-184 & 0 & 1 & 1 & 0 & 1 & 1 & of & 1 & 0 & 0 & 1 \\
\hline GA016-104 & 1 & 1 & 1 & 1 & 1 & 1 & 0 & 1 & 11 & 1 & 1 \\
\hline GA016-114 & 0 & 1 & 0 & 1) & 1 & 11 & 11 & 1) & 11 & of & 0 \\
\hline
\end{tabular}


Anexo 4 - Freqüência de bandas de RAPD, por grupo de variedades de mandioca (em \%)

\begin{tabular}{|c|c|c|c|c|c|c|c|c|}
\hline \begin{tabular}{|l|l} 
Banda & I \\
\end{tabular} & R. Negro & R. Branco & R. Solimões & AMAZÓNIA & Litoral SP & TOTAL & Aipins & Bravas \\
\hline OPX09-A-01 & \begin{tabular}{|r|}
34,78 \\
\end{tabular} & 50,00 & 6.25 & 26.67 & 11.11 & 23,64 & 23.53 & 23,68 \\
\hline OPX14-A-01 & 65,22 & 66,67 & 81.25 & 71,11 & 55,56 & 67,27 & 58,82 & 71,05 \\
\hline OPE01-A-01 & 13,04 & 33,33 & 50.00 & 28.89 & 22.22 & 27,27 & 11,76 & 34,21 \\
\hline OPE01-A-02 & 4,35 & 33,33 & 31,25 & 17,78 & 44,44 & 21,82 & 29,41 & 18,42 \\
\hline OPE03-A-01 & 43,48 & 16,67 & 25,00 & 33,33 & 0,00 & 27,27 & 0,00 & 86,84 \\
\hline OPE03-A-02 & 65,22 & 50,00 & 75,00 & 66.67 & 22.22 & 58,18 & 35,29 & 68,42 \\
\hline OPE03-A-03 & 60.87 & 66,67 & 62,50 & 62,22 & 44,44 & 60,00 & 70,59 & 55,26 \\
\hline OPE05-A-01 & 91,30 & 66,67 & 75,00 & 82,22 & 88.89 & 83,64 & 94,12 & 78,95 \\
\hline OPE05-A-02 & 100,00 & 83,33 & 100,00 & 97,78 & 88,89 & 96,36 & 94,12 & 97,37 \\
\hline OPE05-A-03 & 34,78 & 0,00 & 18.75 & 24.44 & 0,00 & 20,00 & 0,00 & 28,95 \\
\hline OPE06-A-01 & 30,43 & 33,33 & 31,25 & 31,11 & 0,00 & 25,45 & 11,76 & 31,58 \\
\hline OPE07-A-01 & 13,04 & 50,00 & 31,25 & 24,44 & 88,89 & 36,36 & 94,12 & 10,53 \\
\hline OPE07-A-02 & 60.87 & 50,00 & 75,00 & 64,44 & 55,56 & 61,82 & 35,29 & 73,68 \\
\hline OPE09-A-01 & 43,48 & 16,67 & 25,00 & 33,33 & 11,11 & 29,09 & 5.88 & 39,47 \\
\hline OPE09-A-02 & 34,78 & 16,67 & 43,75 & 35,56 & 22,22 & 32,73 & 17.65 & 39,47 \\
\hline OPE10-A-01 & 69.57 & 83,33 & 68,75 & 71,11 & 77,78 & 72,73 & 76,47 & 71,05 \\
\hline OPE10-A-02 & 8.70 & 16,67 & 6,25 & 8,89 & 22,22 & 10,91 & 35,29 & 0,00 \\
\hline OPE10-A-03 & 17,39 & 16,67 & 43,75 & 26.67 & 0,00 & 21,82 & 23,53 & 21,05 \\
\hline OPE $10-A-04$ & 56,52 & 16,67 & 43,75 & 46,67 & 22,22 & 41,82 & 29,41 & 47,37 \\
\hline OPE11-A-01 & 65,22 & 100,00 & 75,00 & 73,33 & 77,78 & 74,55 & 76,47 & 73,68 \\
\hline OPE11-A-02 & 82,61 & 83,33 & 75,00 & 80,00 & 77,78 & 80,00 & 58,82 & 89,47 \\
\hline OPE $15-A-01$ & 91,30 & 66,67 & 68,75 & 80,00 & 11,11 & 69,09 & 47,06 & 78,95 \\
\hline OPE15-A-02 & 73,91 & 66,67 & 68,75 & 71,11 & 22,22 & 61,82 & 11,76 & 84,21 \\
\hline OPE15-A-03 & 91,30 & 83,33 & 93,75 & 91,11 & 77,78 & 89,09 & 76,47 & 94,74 \\
\hline OPE16-A-A1 & 91,30 & 100,00 & 75,00 & 86.67 & 100,00 & 89,09 & 100,00 & 84,21 \\
\hline OPE 16-A-02 & 34,78 & 33,33 & 37,50 & 35,56 & 0,00 & 29,09 & 0,00 & 42,11 \\
\hline OPE17-A-01 & 82,61 & 16,67 & 81,25 & 73,33 & 88,89 & 74,55 & 70,59 & 76,32 \\
\hline OPE17-A-02 & 52,17 & 100,00 & 100,00 & 75,56 & 88,89 & 78,18 & 94,12 & 71,05 \\
\hline OPE 17-A-03 & 0,00 & 0,00 & 6,25 & 2,22 & 22.22 & 5,45 & 11,76 & 2,63 \\
\hline OPE17-A-04 & 30,43 & 100,00 & 56,25 & 48,89 & 33,33 & 47,27 & 41,18 & 50,00 \\
\hline OPE 19-A-01 & 21,74 & 83,33 & 43,75 & 37,78 & 0,00 & 30,91 & 17,65 & 36,84 \\
\hline OPE20-A-01 & 52,17 & 50,00 & 25,00 & 42,22 & 33,33 & 40,00 & 29.41 & 44,74 \\
\hline OPE20-A-02 & 82.61 & 100,00 & 100,00 & 91,11 & 88,89 & 90,91 & 94,12 & 89,47 \\
\hline OPX01-B-01 & 0.00 & 33,33 & 25,00 & 13,33 & 0.00 & 10,91 & 0,00 & 15,79 \\
\hline OPX01-B-02 & 4,35 & 0,00 & 0,00 & 2,22 & 11,11 & 3,64 & 5,88 & 2,63 \\
\hline OPX01-B-03 & 95,65 & 66,67 & 68,75 & 82,22 & 88,89 & 83,64 & 88,24 & 81,58 \\
\hline OPX01-B-04 & 100,00 & 100,00 & 93,75 & 97,78 & 88,89 & 96,36 & 94,12 & 97,37 \\
\hline OPX01-B-05 & 17,39 & 0,00 & 12.50 & 13,33 & 11,11 & 12,73 & 5,88 & 15,79 \\
\hline OPX01-B-06 & 4,35 & 33,33 & 25,00 & 15,56 & 11,11 & 14,55 & 5,88 & 18,42 \\
\hline OPX01-B-07 & 100,00 & 100,00 & 93,75 & 97,78 & 100,00 & 98,18 & 94,12 & 100,00 \\
\hline OPX01-B-08 & 4,35 & 50,00 & 43,75 & 24,44 & 77,78 & 34,55 & 64,71 & 21,05 \\
\hline OPX01-B-09 & 95,65 & 83,33 & 100,00 & 95,56 & 100,00 & 96,36 & 94,12 & 97,37 \\
\hline OPX01-B-10 & 21,74 & 33,33 & 31,25 & 26,67 & 44,44 & 29,09 & 64,71 & 13,16 \\
\hline OPX03-B-01 & 91,30 & 100,00 & 81,25 & 88,89 & 100,00 & 89,09 & 82,35 & 92,11 \\
\hline OPX03-B-02 & 82,61 & 100,00 & 68,75 & 80,00 & 77,78 & 78,18 & 76,47 & 78,95 \\
\hline OPX04-B-01 & 73,91 & 83,33 & 81,25 & 77,78 & 100,00 & 81,82 & 100,00 & 73,68 \\
\hline OPX04-B-02 & 21,74 & 16,67 & 43,75 & 28,89 & 0,00 & 23,64 & 0,00 & 34,21 \\
\hline OPX05-B-01 & 69.57 & 33,33 & 62,50 & 62,22 & 22,22 & 54,55 & 17,65 & 71,05 \\
\hline OPX05-B-02 & 82,61 & 100,00 & 87,50 & 86.67 & 100,00 & 89,09 & 100,00 & 84,21 \\
\hline OPX06-B-01 & 8,70 & 0,00 & 0,00 & 4.44 & 0,00 & 3,64 & 0,00 & 5,26 \\
\hline OPX07-B-01 & 47,83 & 33,33 & 43,75 & 44,44 & 0,00 & 36,36 & 0.00 & 52,63 \\
\hline OPX08-B-01 & 0,00 & 33,33 & 25,00 & 13,33 & 0,00 & 10,91 & 0,00 & 15,79 \\
\hline OPX08-B-02 & 95,65 & 66,67 & 75,00 & 84,44 & 88,89 & 85,45 & 94,12 & 81,58 \\
\hline OPX08-B-03 & 4,35 & 0,00 & 0,00 & 2,22 & 11,11 & 3,64 & 5.88 & 2,63 \\
\hline OPX09-B-01 & 100,00 & 66,67 & 68,75 & 84,44 & 77.78 & 83,64 & 82,35 & 84,21 \\
\hline
\end{tabular}


Anexo \& - Freqüência de bandas de RAPD, por grupo de variedades de mandioca

(Continuação)

\begin{tabular}{|c|c|c|c|c|c|c|c|c|}
\hline Banda & R. Negro & R. Branco & R. Solimães & AMAZÓNIA & Litoral SP & TOTAL & Aipins & Bravas \\
\hline OPX11-B-01 & \begin{tabular}{|r|}
30.43 \\
\end{tabular} & 0,00 & 0.00 & $\begin{array}{r}5.56 \\
\end{array}$ & 0.00 & \begin{tabular}{|l|}
12,73 \\
\end{tabular} & 0.00 & 18.42 \\
\hline OPX11-B-02 & 8.70 & 50.00 & 12.50 & 15.56 & 0,00 & 12,73 & 0,00 & 18.42 \\
\hline OPX12-B-01 & 0.00 & 33,33 & 25.00 & 13,33 & 0,00 & 10,91 & 0.001 & 15,79 \\
\hline OPX13-B-01 & 43.48 & 66.67 & 25,00 & 40,00 & 11,11 & 34,55 & 23,53 & 39,47 \\
\hline $\mathrm{OPX} 14-\mathrm{B}-01$ & 4.35 & 33.33 & 25,00 & 15,56 & 11,11 & 14,55 & 11.76 & 15,79 \\
\hline OPX14-B-02 & 78,26 & 66,67 & 75.00 & 75.56 & 88,89 & 78,18 & 82,35 & 76,32 \\
\hline OPX16-B-01 & 65,22 & 100,00 & 75,00 & 73.33 & 100,00 & 78,18 & 100,00 & 68,42 \\
\hline $\mathrm{OPX} 16-\mathrm{B}-02$ & 95,65 & 83.33 & 87,50 & 91,11 & 77,78 & 89,09 & 88,24 & 89,47 \\
\hline OPX16-B-03 & 43,48 & 83,33 & 43,75 & 48.89 & 55,56 & 50,91 & 76.47 & 39,47 \\
\hline OPX17-B-01 & 4.35 & 16,67 & 6,25 & 6,67 & 0,00 & 5,45 & 11,76 & 2,63 \\
\hline OPX17-B-02 & 100,00 & 100,00 & 100,00 & 100,00 & 66,67 & 94,55 & 82,35 & 100,00 \\
\hline OPX18-B-01 & 30,43 & 50,00 & 12.50 & 26.67 & 55,56 & 32,73 & 52,94 & 23,68 \\
\hline OPX19-B-01 & 78,26 & 66,67 & 75,00 & 75.56 & 100.00 & 78,18 & 82,35 & 76,32 \\
\hline OPX20-B-01 & 69,57 & 100,00 & 43,75 & 64.44 & 33,33 & 60,00 & 47,06 & 65,79 \\
\hline OPE07-B-01 & 43,48 & 16,67 & 37.50 & 37.78 & 33,33 & 36,36 & 23,53 & 42,11 \\
\hline OPE08-B-02 & 17.39 & 16.67 & 25,00 & 20.00 & 44,44 & 23,64 & 35,29 & 18,42 \\
\hline OPE10-B-01 & 69,57 & 50.00 & 75.00 & 68,89 & 0,00 & 56,36 & 17.65 & 73,68 \\
\hline OPE10-B-02 & 21,74 & 0,00 & 0,00 & 11,11 & 0.00 & 9,09 & 0,00 & 13,16 \\
\hline OPE10-B-03 & 17,39 & 33,33 & 50,00 & 31,11 & 88,89 & 40,00 & 82,35 & 21,05 \\
\hline OPE10-B-04 & 52,17 & 33,33 & 12,50 & 35,56 & 100,00 & 47,27 & 94,12 & 26,32 \\
\hline OPE11-B-01 & 78,26 & 66,67 & 87,50 & 80,00 & 88,89 & 81,82 & 88,24 & 78,95 \\
\hline OPE12-B-01 & 8,70 & 33,33 & 18,75 & 15.56 & 0,00 & 12,73 & 23,53 & 7.89 \\
\hline OPE15-B-01 & 4,35 & 33,33 & 31,25 & 17.78 & 11,11 & 16,36 & 23,53 & 13,16 \\
\hline OPE16-B-01 & 39,13 & 33,33 & 25,00 & 33,33 & 0,00 & 27,27 & 5,88 & 36,84 \\
\hline OPE $17-B-01$ & 52,17 & 83,33 & 81,25 & 66.67 & 55,56 & 63,64 & 64,71 & 63,16 \\
\hline OPE17-B-02 & 86,96 & 100,00 & 93,75 & 91,11 & 88,89 & 90,91 & 94,12 & 89,47 \\
\hline OPE17-B-03 & 34,78 & 33,33 & 25,00 & 31,11 & 33,33 & 30,91 & 35,29 & 28,95 \\
\hline OPE17-B-04 & 43,48 & 16,67 & 12,50 & 28.89 & 0,00 & 23,64 & 0,00 & 34,21 \\
\hline OPE 19-B-01 & 65,22 & 100,00 & 100,00 & 82,22 & 100,00 & 85,45 & 100,00 & 78,95 \\
\hline OPE19-B-02 & 0,00 & 0,00 & 0,00 & 0,00 & 22,22 & 3,64 & 11,76 & 0,00 \\
\hline OPE20-B-01 & 86,96 & 66,67 & 68,75 & 77,78 & 11,11 & 67,27 & 29,41 & 84,21 \\
\hline OPE20-B-02 & 52,17 & 50,00 & 6,25 & 35.56 & 0,00 & 29,09 & 5,88 & 39,47 \\
\hline OPE01-AM1 & 100.00 & 100,00 & 100,00 & 100,00 & 100,00 & 100,00 & 100,00 & 100,00 \\
\hline OPE01-AM2 & 100,00 & 100,00 & 100,00 & 100,00 & 100,00 & 100,00 & 100,00 & 100,00 \\
\hline OPE02-AM1 & 100,00 & 100,00 & 100,00 & 100,00 & 100,00 & 100,00 & 100,00 & 100,00 \\
\hline OPE03-AMI & 100,00 & 100,00 & 100,00 & 100,00 & 100,00 & 100,00 & 100,00 & 100,00 \\
\hline OPE03-AM2 & 100,00 & 100,00 & 100,00 & 100,00 & 100,00 & 100,00 & 100,00 & 100,00 \\
\hline OPEO3-AM3 & 100,00 & 100,00 & 100,00 & 100,00 & 100,00 & 100,00 & 100,00 & 100,00 \\
\hline OPE03-AMA & 100,00 & 100,00 & 100,00 & 100,00 & 100,00 & 100,00 & 100,00 & 100,00 \\
\hline OPE04-AM1 & 100,00 & 100,00 & 100,00 & 100,00 & 100,00 & 100,00 & 100,00 & 100,00 \\
\hline OPEO5-AM1 & 100,00 & 100,00 & 100,00 & 100,00 & 100,00 & 100,00 & 100,00 & 100,00 \\
\hline OPE07-AM1 & 100,00 & 100,00 & 100,00 & 100,00 & 100,00 & 100,00 & 100,00 & 100,00 \\
\hline OPE07-AM2 & 100,00 & 100,00 & 100,00 & 100,00 & 100,00 & 100,00 & 100,00 & 100,00 \\
\hline OPE07-AM3 & 100,00 & 100,00 & 100,00 & 100,00 & 100,00 & 100,00 & 100,00 & 100,00 \\
\hline OPE07-AM4 & 100,00 & 100,00 & 100,00 & 100,00 & 100,00 & 100,00 & 100,00 & 100,00 \\
\hline OPE10-AM1 & 100,00 & 100,00 & 100.00 & 100,00 & 100,00 & 100,00 & 100,00 & 100,00 \\
\hline OPE11-AM1 & 100,00 & 100,00 & 100,00 & 100,00 & 100,00 & 100,00 & 100,00 & 100,00 \\
\hline OPX01-BM1 & 100.00 & 100,00 & 100,00 & 100.00 & 100,00 & 100,00 & 100,00 & 100,00 \\
\hline OPX01-BM2 & 100,00 & 100,00 & 100,00 & 100,00 & 100,00 & 100,00 & 100,00 & 100,00 \\
\hline OPX01-BM3 & 100,00 & 100,00 & 100,00 & 100,00 & 100,00 & 100,00 & 100,00 & 100,00 \\
\hline OPX02-BM1 & 100,00 & 100,00 & 100,00 & 100,00 & 100,00 & 100,00 & 100,00 & 100,00 \\
\hline OPX02-BM2 & 100,00 & 100,00 & 100,00 & 100,00 & 100,00 & 100,00 & 100,00 & 100,00 \\
\hline OPX03-BM1 & 100,00 & 100,00 & 100,00 & 100,00 & 100,00 & 100,00 & 100,00 & 100,00 \\
\hline OPX03-BM2 & 100,00 & 100,00 & 100,00 & 100,00 & 100,00 & 100,00 & 100,00 & 100,00 \\
\hline OPX03-BM3 & 100,00 & 100,00 & 100,00 & 100,00 & 100,00 & 100,00 & 100,00 & 100,00 \\
\hline
\end{tabular}


Anexo 4 - Frequência de bandas de RAPD, por grupo (Continuação)

\begin{tabular}{|c|c|c|c|c|c|c|c|c|}
\hline Banda & R. Negro & R. Branco & R. Solimões & AMAZÓNIA & Litoral SP & TOTAL & Aipins & Bravias \\
\hline OPX03-BM4 & 100,00 & 100,00 & \begin{tabular}{|l|}
100,00 \\
\end{tabular} & 100,00 & 100.00 & \begin{tabular}{|l|}
100,00 \\
\end{tabular} & 100,00 & 100,00 \\
\hline OPX04-BM1 & 100,00 & 100,00 & 100,00 & 100,00 & 100,00 & 100,00 & 100,00 & 100,00 \\
\hline OPX05-BM1 & 100,00 & 100,00 & 100,00 & 100,00 & 100,00 & 100,00 & 100,00 & 100,00 \\
\hline OPX05-BM2 & 100,00 & 100,00 & 100,00 & 100,00 & 100,00 & 100,00 & 100,00 & 100,00 \\
\hline OPX06-BMI & 100,00 & 100,00 & 100,00 & 100,00 & 100,00 & 100,00 & 100.00 & 100,00 \\
\hline OPX06-BM2 & 100,00 & 100,00 & 100,00 & 100.00 & 100,00 & 100,00 & 100,00 & 100,00 \\
\hline OPX06-BM3 & 100,00 & 100,00 & 100.00 & 100,00 & 100,00 & 100,00 & 100,00 & 100,00 \\
\hline OPX06-BM4 & 100,00 & 100,00 & 100,00 & 100,00 & 100,00 & 100,00 & 100,00 & 100,00 \\
\hline OPX07-BM1 & 100,00 & 100,00 & 100,00 & 100,00 & 100,00 & 100,00 & 100,00 & 100,00 \\
\hline OPX07-BM2 & 100,00 & 100,00 & 100,00 & 100,00 & 100,00 & 100,00 & 100,00 & 100,00 \\
\hline OPX09-BM1 & 100,00 & 100,00 & 100.00 & 100,00 & 100,00 & 100,00 & 100,00 & 100,00 \\
\hline OPX10-BM1 & 100,00 & 100,00 & 100,00 & 100,00 & 100,00 & 100,00 & 100,00 & 100,00 \\
\hline OPX11-BM1 & 100,00 & 100,00 & 100,00 & 100,00 & 100,00 & 100,00 & 100,00 & 100,00 \\
\hline OPX11-BM2 & 100,00 & 100,00 & 100,00 & 100.00 & 100,00 & 100,00 & 100,00 & 100,00 \\
\hline OPX11-BM3 & 100,00 & 100.00 & 100,00 & 100,00 & 100,00 & 100,00 & 100,00 & 100,00 \\
\hline OPX11-BM4 & 100,00 & 100.00 & 100,00 & 100,00 & 100,00 & 100,00 & 100,00 & 100,00 \\
\hline OPX12-BM1 & 100,00 & 100,00 & 100,00 & 100.00 & 100,00 & 100,00 & 100,00 & 100,00 \\
\hline OPX12-BM2 & 100,00 & 100,00 & 100,00 & 100,00 & 100,00 & 100,00 & 100,00 & 100,00 \\
\hline OPX12-BM3 & 100,00 & 100,00 & 100,00 & 100,00 & 100,00 & 100,00 & 100,00 & 100,00 \\
\hline OPX12-BM4 & 100,00 & 100,00 & 100,00 & 100,00 & 100,00 & 100,00 & 100.00 & 100,00 \\
\hline OPX12-BM5 & 100,00 & 100,00 & 100,00 & 100,00 & 100,00 & 100,00 & 100,00 & 100,00 \\
\hline OPX12-BM6 & 100,00 & 100,00 & 100,00 & 100,00 & 100,00 & 100,00 & 100,00 & 100,00 \\
\hline OPX12-BM7 & 100,00 & 100,00 & 100,00 & 100,00 & 100,00 & 100,00 & 100,00 & 100,00 \\
\hline OPX13-BM1 & 100,00 & 100,00 & 100,00 & 100.00 & 100,00 & 100,00 & 100,00 & 100,00 \\
\hline OPX14-BMI & 100,00 & 100,00 & 100,00 & 100,00 & 100,00 & 100,00 & 100,00 & 100,00 \\
\hline OPX14-BM2 & 100,00 & 100,00 & 100,00 & 100,00 & 100,00 & 100,00 & 100,00 & 100,00 \\
\hline OPX14-BM3 & 100,00 & 100,00 & 100,00 & 100,00 & 100,00 & 100,00 & 100,00 & 100,00 \\
\hline OPX15-BM1 & 100,00 & 100,00 & 100,00 & 100.00 & 100,00 & 100,00 & 100,00 & 100,00 \\
\hline OPX15-BM2 & 100,00 & 100,00 & 100,00 & 100,00 & 100,00 & 100,00 & 100,00 & 100,00 \\
\hline OPX15-BM3 & 100,00 & 100,00 & 100,00 & 100,00 & 100,00 & 100,00 & 100,00 & 100,00 \\
\hline OPX15-BM4 & 100,00 & 100,00 & 100,00 & 100,00 & 100,00 & 100,00 & 100,00 & 100,00 \\
\hline OPX17-BM1 & 100,00 & 100,00 & 100,00 & 100,00 & 100,00 & 100,00 & 100,00 & 100,00 \\
\hline OPX17-BM2 & 100,00 & 100,00 & 100,00 & 100,00 & 100,00 & 100,00 & 100,00 & 100,00 \\
\hline OPX17-BM3 & 100,00 & 100,00 & 100,00 & 100,00 & 100,00 & 100,00 & 100,00 & 100,00 \\
\hline OPX18-BM1 & 100,00 & 100,00 & 100,00 & 100,00 & 100,00 & 100,00 & 100,00 & 100,00 \\
\hline OPX18-BM2 & 100,00 & 100,00 & 100,00 & 100,00 & 100,00 & 100,00 & 100,00 & 100,00 \\
\hline OPX19-BM1 & 100,00 & 100,00 & 100,00 & 100,00 & 100,00 & 100,00 & 100,00 & 100,00 \\
\hline OPE14-BM1 & 100,00 & 100,00 & 100,00 & 100,00 & 100,00 & 100,00 & 100,00 & 100,00 \\
\hline OPE14-BM2 & 100,00 & 100,00 & 100,00 & 100,00 & 100,00 & 100,00 & 100,00 & 100,00 \\
\hline OPE14-BM3 & 100,00 & 100,00 & 100,00 & 100,00 & 100,00 & 100,00 & 100,00 & 100,00 \\
\hline OPE17-BM1] & 100,00 & 100,00 & 100,00 & 100,00 & 100,00 & 100,00 & 100,00 & 100,00 \\
\hline OPE19-BM1 & 100,00 & 100,00 & 100,00 & 100,00 & 100,00 & 100,00 & 100,00 & 100,00 \\
\hline OPE19-BM2 & 100,00 & 100,00 & 100,00 & 100,00 & 100,00 & 100,00 & 100,00 & 100,00 \\
\hline OPE20-BMI & 100,00 & 100,00 & 100,00 & 100,00 & 100,00 & 100,00 & 100,00 & 100,00 \\
\hline OPE20-BM2 & 100,00 & 100,00 & 100,00 & 100,00 & 100,00 & 100,00 & 100,00 & 100,00 \\
\hline OPE20-BM3 & 100,00 & 100,00 & 100,00 & 100,00 & 100,00 & 100,00 & 100,00 & 100,00 \\
\hline
\end{tabular}


Anexo 5 - Freqüencia de bandas de AFLP, por grupo de variedades de mandioca (em \%)

\begin{tabular}{|c|c|c|c|c|c|c|c|c|}
\hline Banda & R. Negro & R. Brance & R. Solimões & AMAZÔNIA & Litoral SP & TOTAL & Aipins & Bravas \\
\hline $\mathrm{ACA} / \mathrm{CAG}-051$ & 26,09 & 83,33 & 62.50 & 46.67 & 44.44 & 47,27 & 58,82 & 42,11 \\
\hline $\mathrm{ACA} / \mathrm{CAG}-052$ & 17,39 & 16,67 & 25,00 & 20.00 & 0.00 & 16,36 & 5,88 & 21,05 \\
\hline $\mathrm{ACA} / \mathrm{CAG}-056$ & 100,00 & 100,00 & 100,00 & 100.00 & 77.78 & 96,36 & 88,24 & 100,00 \\
\hline $\mathrm{ACA} / \mathrm{CAG}-058$ & 21,74 & 0,00 & 0.00 & 11,11 & 44.44 & 16,36 & 23,53 & 13,16 \\
\hline $\mathrm{ACA} / \mathrm{CAG}-060$ & 100,00 & 100,00 & 100,00 & 100.00 & 100.00 & 100,00 & 100,00 & 100,00 \\
\hline $\mathrm{ACA} / \mathrm{CAG}-063$ & 95,65 & 100,00 & 100,00 & 97,78 & 100.00 & 98,18 & 100,00 & 97,37 \\
\hline ACA/CAG-066 & 86,96 & 83,33 & 81,25 & 84,44 & 88.89 & 83,64 & 88,24 & 81,58 \\
\hline $\mathrm{ACA} / \mathrm{CAG}-069$ & 100,00 & 100,00 & 87,50 & 95.56 & 100.00 & 96,36 & 94,12 & 97,37 \\
\hline $\mathrm{ACA} / \mathrm{CAG}-071$ & 95,65 & 83,33 & 87,50 & 91,11 & 100.00 & 92,73 & 100,00 & 89,47 \\
\hline ACA/CAG-074 & 100,00 & 100,00 & 100,00 & 100,00 & 100,00 & 100,00 & 100,00 & 100,00 \\
\hline $\mathrm{ACA} / \mathrm{CAG}-075$ & 100,00 & 100,00 & 100,00 & 100,00 & 100.00 & 100,00 & 100,00 & 100,00 \\
\hline $\mathrm{ACA} / \mathrm{CAG}-079$ & 69,57 & 83,33 & 87,50 & 77.78 & 100.00 & 81,82 & 100,00 & 73,68 \\
\hline $\mathrm{ACA} / \mathrm{CAG}-082$ & 100.00 & 100,00 & 100,00 & 100.00 & 100,00 & 100,00 & 100,00 & 100,00 \\
\hline $\mathrm{ACA} / \mathrm{CAG}-085$ & 100,00 & 100,00 & 100.00 & 100,00 & 100.00 & 100,00 & 100,00 & 100,00 \\
\hline ACA/CAG-089 & 69,57 & 100,00 & 50,00 & 66,67 & 100,00 & 72,73 & 100,00 & 60,53 \\
\hline ACA/CAG-094 & 91.30 & 100,00 & 100,00 & 95.56 & 100.00 & 96,36 & 100,00 & 94,74 \\
\hline $\mathrm{ACA} / \mathrm{CAG}-095$ & 82,61 & 50,00 & 43,75 & 64,44 & 0.00 & 52,73 & 17,65 & 68,42 \\
\hline $\mathrm{ACA} / \mathrm{CAG}-110$ & 100,00 & 100,00 & 100,00 & 100,00 & 100.00 & 100,00 & 100,00 & 100,00 \\
\hline ACA/CAG-113 & 100,00 & 100,00 & 100,00 & 100,00 & 100,00 & 100,00 & 100,00 & 100,00 \\
\hline $\mathrm{ACA} / \mathrm{CAG}-143$ & 65,22 & 83,33 & 75,00 & 71,11 & 100.00 & 76,36 & 94,12 & 68,42 \\
\hline $\mathrm{ACA} / \mathrm{CAG}-156$ & 34,78 & 16,67 & 25,00 & 28,89 & 11,11 & 25,45 & 5,88 & 34,21 \\
\hline ACA/CAG-159 & 86,96 & 83,33 & 100,00 & 91,11 & 100,00 & 92,73 & 94,12 & 92.11 \\
\hline $\mathrm{ACA} / \mathrm{CAG}-187$ & 100,00 & 100,00 & 81,25 & 93,33 & 100,00 & 94,55 & 100,00 & 92,11 \\
\hline $\mathrm{ACA} / \mathrm{CAG}-190$ & 100,00 & 100,00 & 100,00 & 100,00 & 100,00 & 100,00 & 100,00 & 100,00 \\
\hline ACA/CAG-206 & 73,91 & 66,67 & 93,75 & 80,00 & 100.00 & 83,64 & 82,35 & 84,21 \\
\hline $\mathrm{ACA} / \mathrm{CAG}-211$ & 100,00 & 100,00 & 100,00 & 100,00 & 100,00 & 100,00 & 100,00 & 100,00 \\
\hline $\mathrm{ACA} / \mathrm{CAG}-250$ & 100,00 & 100,00 & 100,00 & 100,00 & 100,00 & 100,00 & 100,00 & 100,00 \\
\hline $\mathrm{ACA} / \mathrm{CAG}-274$ & 69,57 & 100,00 & 93,75 & 82,22 & 100,00 & 85,45 & 94,12 & 81,58 \\
\hline $\mathrm{ACA} / \mathrm{CAG}-286$ & 100,00 & 100,00 & 100,00 & 100,00 & 100,00 & 100,00 & 100,00 & 100,00 \\
\hline $\mathrm{ACA} / \mathrm{CAG}-295$ & 95,65 & 100,00 & 100,00 & 97,78 & 100.00 & 98,18 & 100,00 & 97,37 \\
\hline $\mathrm{ACA} / \mathrm{CAG}-301$ & 100,00 & 100,00 & 100,00 & 100,00 & 100,00 & 100,00 & 100,00 & 100,00 \\
\hline $\mathrm{ACA} / \mathrm{CAG}-304$ & 86,96 & 83,33 & 62,50 & 77,78 & 66,67 & 76,36 & 47,06 & 89,47 \\
\hline $\mathrm{ACA} / \mathrm{CAG}-331$ & 56,52 & 50,00 & 75,00 & 62,22 & 66,67 & 63,64 & 52,94 & 68,42 \\
\hline ACA/CTC-058 & 100,00 & 100,00 & 100,00 & 100,00 & 100,00 & 100,00 & 100,00 & 100,00 \\
\hline $\mathrm{ACA} / \mathrm{CTC}-063$ & 8,70 & 16,67 & 25,00 & 15,56 & 88.89 & 27,27 & 70,59 & $\begin{array}{r}7,89 \\
\end{array}$ \\
\hline ACA/CTC-065 & 69,57 & 33,33 & 62,50 & 62,22 & 22,22 & 54,55 & 47,06 & 57,89 \\
\hline $\mathrm{ACA} / \mathrm{CTC}-067$ & 4,35 & 0,00 & 0,00 & 2,22 & 0.00 & 1,82 & 0,00 & 2,63 \\
\hline $\mathrm{ACA} / \mathrm{CTC}-070$ & 95,65 & 100,00 & 100,00 & 97,78 & 100.00 & 98,18 & 100,00 & 97,37 \\
\hline ACA/CTC-076 & 21,74 & 16,67 & 6,25 & 15,56 & 22,22 & 18,18 & 17,65 & 18,42 \\
\hline ACA/CTC-098 & 4,35 & 0,00 & 0,00 & 2,22 & 33,33 & 7,27 & 17,65 & 2,63 \\
\hline $\mathrm{ACA} / \mathrm{CTC}-100$ & 78,26 & 100,00 & 87,50 & 84,44 & 88,89 & 85,45 & 88,24 & 84,21 \\
\hline $\mathrm{ACA} / \mathrm{CTC}-102$ & 100,00 & 100,00 & 100,00 & 100,00 & 100,00 & 100,00 & 100,00 & 100,00 \\
\hline $\mathrm{ACA} / \mathrm{CTC}-106$ & 86,96 & 100,00 & 87,50 & 88,89 & 55,56 & 83,64 & 64,71 & 92,11 \\
\hline $\mathrm{ACA} / \mathrm{CTC}-107$ & 34,78 & 83,33 & 68,75 & 53,33 & 44,44 & 52,73 & 64,71 & 47,37 \\
\hline $\mathrm{ACA} / \mathrm{CTC}-112$ & 69,57 & 66,67 & 87,50 & 75,56 & 100,00 & 80,00 & 100,00 & 71,05 \\
\hline $\mathrm{ACA} / \mathrm{CTC}-113$ & 30,43 & 50,00 & 43,75 & 37,78 & 22.22 & 36,36 & 35,29 & 36,84 \\
\hline ACA/CTC-115 & 100,00 & 100,00 & 100,00 & 100,00 & 100.00 & 100,00 & 100,00 & 100,00 \\
\hline $\mathrm{ACA} / \mathrm{CTC}-116$ & 86,96 & 83,33 & 68,75 & 80,00 & 100.00 & 83,64 & 100,00 & 76,32 \\
\hline $\mathrm{ACA} / \mathrm{CTC}-133$ & 100,00 & 100,00 & 100,00 & 100,00 & 100,00 & 100,00 & 100,00 & 100,00 \\
\hline ACA/CTC-140 & 91,30 & 100,00 & 100,00 & 95,56 & 100,00 & 96,36 & 100,00 & 94,74 \\
\hline ACA/CTC-156 & 4,35 & 50,00 & 37,50 & 22,22 & 66,67 & 30,91 & 58,82 & 18,42 \\
\hline ACA/CTC-164 & 26,09 & 66.67 & 50,00 & 40,00 & 55.56 & 43,64 & 70,59 & 31,58 \\
\hline
\end{tabular}


Anexo 5 - Freqüência de bandas de AFLP, por grapo de variedades de mandioca (Continuação)

\begin{tabular}{|c|c|c|c|c|c|c|c|c|}
\hline Banda & R. Negro & R. Branco & R. Solimões & AMAZÔNIA & Litoral SP & TOTAL & Aipins & Bravas \\
\hline $\mathrm{ACA} / \mathrm{CTC}-171$ & 30.43 & 16.67 & $\begin{array}{r}37.50 \\
\end{array}$ & 31,11 & $\begin{array}{r}33.33 \\
\end{array}$ & 30,91 & 47,06 & 23.68 \\
\hline $\mathrm{ACA} / \mathrm{CTC}-187$ & 52,17 & 16.67 & 25.00 & 37.78 & 22.22 & 34,55 & 11.76 & 44.74 \\
\hline ACA/CTC-192 & 100.00 & 100,00 & 100.00 & 100,00 & 100,00 & 100,00 & 100,00 & 100,00 \\
\hline ACA/CTC-201 & 100.00 & 100,00 & 100,00 & 100,00 & 100.00 & 100,00 & 100,00 & 100,00 \\
\hline $\mathrm{ACA} / \mathrm{CTC}-210$ & 86,96 & 83,33 & 87.50 & 86,67 & 88.89 & 87,27 & 82,35 & 89.47 \\
\hline $\mathrm{ACA} / \mathrm{CTC}-212$ & 21.74 & 16,67 & 0,00 & 13,33 & 11,11 & 12,73 & 5.88 & 15,79 \\
\hline ACA/CTC-226 & 8.70 & 16.67 & 6.25 & 8,89 & 11,11 & 10,91 & 17.65 & 7,89 \\
\hline ACA/CTC-227 & 8,70 & 16,67 & 0,00 & 6,67 & 0,00 & 5,45 & 17,65 & 0,00 \\
\hline $\mathrm{ACA} / \mathrm{CTC}-230$ & 43,48 & 16.67 & 18,75 & 31,11 & 11,11 & 27,27 & 23,53 & 28,95 \\
\hline $\mathrm{ACA} / \mathrm{CTC}-244$ & 43,48 & 50,00 & 25,00 & 37,78 & 0,00 & 30,91 & 0,00 & 44,74 \\
\hline $\mathrm{ACA} / \mathrm{CTC}-269$ & 82,61 & 50,00 & 81.25 & 77,78 & 22,22 & 67,27 & 41,18 & 78,95 \\
\hline ACA/CTC-270 & 91,30 & 50,00 & 31,25 & 64,44 & 0,00 & 54,55 & 17,65 & 71,05 \\
\hline $\mathrm{ACA} / \mathrm{CTC}-287$ & 100.00 & 100,00 & 100,00 & 100,00 & 100,00 & 100,00 & 100,00 & 100,00 \\
\hline $\mathrm{ACA} / \mathrm{CTC}-293$ & 26,09 & 33,33 & 12.50 & 22,22 & 0,00 & 18,18 & 0,00 & 26,32 \\
\hline $\mathrm{ACA} / \mathrm{CTC}-296$ & 91,30 & 83,33 & 37,50 & 71,11 & 88,89 & 74,55 & 82,35 & 71.05 \\
\hline $\mathrm{ACA} / \mathrm{CTC}-309$ & 17,39 & 0,00 & 6.25 & 11,11 & 22,22 & 12,73 & 11,76 & 13,16 \\
\hline $\mathrm{ACA} / \mathrm{CTC}-322$ & 95.65 & 100.00 & 100,00 & 97,78 & 100,00 & 98,18 & 100,00 & 97,37 \\
\hline $\mathrm{ACT} / \mathrm{CAC}-062$ & 100,00 & 100,00 & 100,00 & 100,00 & 100,00 & 100,00 & 100,00 & 100,00 \\
\hline $\mathrm{ACT} / \mathrm{CAC}-064$ & 4.35 & 0,00 & 0,00 & 2,22 & 0,00 & 1,82 & 0,00 & 2,63 \\
\hline ACT/CAC-081 & 13,04 & 16,67 & 31,25 & 20,00 & 88.89 & 30,91 & 88,24 & 5,26 \\
\hline ACT/CAC-084 & 100,00 & 100,00 & 100,00 & 100,00 & 100,00 & 100,00 & 100,00 & 100,00 \\
\hline $\mathrm{ACT} / \mathrm{CAC}-089$ & 4,35 & 0,00 & 0,00 & 2,22 & 0,00 & 1,82 & 5.88 & 0,00 \\
\hline $\mathrm{ACT} / \mathrm{CAC}-091$ & 78,26 & 33,33 & 62,50 & 66,67 & 11,11 & 58,18 & 29,41 & 71,05 \\
\hline ACT/CAC-108 & 21.74 & 50,00 & 31,25 & 28,89 & 88,89 & 40,00 & 64,71 & 28,95 \\
\hline $\mathrm{ACT} / \mathrm{CAC}-110$ & 78,26 & 100,00 & 81,25 & 82,22 & 88,89 & 83,64 & 94,12 & 78,95 \\
\hline ACT/CAC-116 & 43,48 & 0,00 & 56,25 & 42,22 & 0,00 & 34,55 & 0,00 & 50,00 \\
\hline ACT/CAC-118 & 39,13 & 50,00 & 12,50 & 31,11 & 44,44 & 32,73 & 23,53 & 36,84 \\
\hline $\mathrm{ACT} / \mathrm{CAC}-120$ & 100,00 & 100,00 & 100,00 & 100,00 & 100,00 & 100,00 & 100,00 & 100,00 \\
\hline $\mathrm{ACT} / \mathrm{CAC}-124$ & 56.52 & 66,67 & 56.25 & 57,78 & 100,00 & 65,45 & 94.12 & 52.63 \\
\hline $\mathrm{ACT} / \mathrm{CAC}-127$ & 4,35 & 16,67 & 0,00 & 4,44 & 55,56 & 14,55 & 41,18 & 2,63 \\
\hline $\mathrm{ACT} / \mathrm{CAC}-140$ & 73,91 & 83,33 & 75,00 & 75,56 & 0,00 & 61,82 & 0,00 & 89,47 \\
\hline $\mathrm{ACT} / \mathrm{CAC}-143$ & 39,13 & 33,33 & 43,75 & 40,00 & 100,00 & 50,91 & 70,59 & 42,11 \\
\hline $\mathrm{ACT} / \mathrm{CAC}-164$ & 91,30 & 83.33 & 75,00 & 84,44 & 100.00 & 87,27 & 100,00 & 81,58 \\
\hline ACT/CAC-167 & 100,00 & 100,00 & 100,00 & 100,00 & 100,00 & 100,00 & 100,00 & 100,00 \\
\hline $\mathrm{ACT} / \mathrm{CAC}-175$ & 73,91 & 100,00 & 25,00 & 60,00 & 100,00 & 67,27 & 94,12 & 55,26 \\
\hline $\mathrm{ACT} / \mathrm{CAC}-188$ & 4,35 & 66,67 & 12,50 & 15,56 & 11,11 & 16,36 & 23,53 & 13,16 \\
\hline ACT/CAC-189 & 82,61 & 83,33 & 93,75 & 86,67 & 77,78 & 85,45 & 88,24 & 84,21 \\
\hline ACT/CAC-201 & 26,09 & 0,00 & 43,75 & 28.89 & 0,00 & 23,64 & 0,00 & 34,21 \\
\hline ACT/CAC-214 & 43,48 & 16,67 & 31,25 & 35,56 & 22,22 & 32,73 & 11,76 & 42,11 \\
\hline $\mathrm{ACT} / \mathrm{CAC}-226$ & 82.61 & 83,33 & 87,50 & 84,44 & 77,78 & 83,64 & 82,35 & 84,21 \\
\hline $\mathrm{ACT} / \mathrm{CAC}-230$ & 30,43 & 50,00 & 0,00 & 22,22 & 88,89 & 34,55 & 58,82 & 23,68 \\
\hline $\mathrm{ACT} / \mathrm{CAC}-234$ & 100.00 & 100,00 & 87,50 & 95,56 & 100,00 & 96,36 & 94,12 & 97,37 \\
\hline $\mathrm{ACT} / \mathrm{CAC}-276$ & 100,00 & 100,00 & 100,00 & 100,00 & 100,00 & 100,00 & 100,00 & 100,00 \\
\hline $\mathrm{ACT} / \mathrm{CAC}-310$ & 100,00 & 100,00 & 100,00 & 100,00 & 100,00 & 100,00 & 100,00 & 100,00 \\
\hline $\mathrm{ACT} / \mathrm{CAC}-340$ & 8.70 & 0,00 & 12,50 & 8,89 & 0,00 & 7,27 & 0,00 & 10,53 \\
\hline AGG/CAA-054 & 95.65 & 100,00 & 100,00 & 97,78 & 100,00 & 98,18 & 94,12 & 100,00 \\
\hline AGG/CAA-056 & 13,04 & 0,00 & 6,25 & 8.89 & 55.56 & 16,36 & 35,29 & 7,89 \\
\hline $\mathrm{AGG} / \mathrm{CAA}-057$ & 73,91 & 16,67 & 56,25 & 60,00 & 0,00 & 50,91 & 11,76 & 68,42 \\
\hline AGG/CAA-060 & 100,00 & 100,00 & 100,00 & 100,00 & 100.00 & 100,00 & 100,00 & 100,00 \\
\hline AGG/CAA-065 & 17,39 & 16.67 & 12,50 & 15,56 & 11,11 & 14,55 & 5,88 & 18,42 \\
\hline AGG/CAA-070 & 100,00 & 100,00 & 100,00 & 100.00 & 100,00 & 100,00 & 100.00 & 100,00 \\
\hline AGG/CAA-071 & 56,52 & 33,33 & 50,00 & 51,11 & 88.89 & 58,18 & 64,71 & 55,26 \\
\hline
\end{tabular}


Anexo 5 - Freqüência de bandas de AFLP, por grupo de variedades de mandioca

(Continuação)

\begin{tabular}{|c|c|c|c|c|c|c|c|c|}
\hline Banda & R. Negro & R. Branco & R. Solimōes & AMAZÓNIA & Litoral SP & TOTAL & Aipins & Bravas \\
\hline AGG/CAA-072 & 100,00 & 100,00 & 87,50 & 95.56 & 44.44 & 85,45 & 58,82 & 97,37 \\
\hline AGG/CAA-075 & 100,00 & 100,00 & 87.50 & 95.56 & 77.78 & 92,73 & 88,24 & 94,74 \\
\hline AGG/CAA-078 & 100,00 & 100,00 & 100,00 & 100.00 & 100,00 & 100,00 & 100,00 & 100,00 \\
\hline AGG/CAA-079 & 69,57 & 16,67 & 62,50 & 60.00 & 33.33 & 54,55 & 17.65 & 71,05 \\
\hline AGG/CAA-080 & 100,00 & 100.00 & 100.00 & 100,00 & 100.00 & 100,00 & 100,00 & 100,00 \\
\hline AGG/CAA-083 & 26,09 & 0,00 & 12,50 & 17,78 & 11,11 & 16,36 & 5,88 & 21,05 \\
\hline $\mathrm{AGG/CAA-093}$ & 100,00 & 100,00 & 100,00 & 100,00 & 100.00 & 100,00 & 100,00 & 100,00 \\
\hline AGG/CAA-103 & 100,00 & 100,00 & 100,00 & 100.00 & 100,00 & 100,00 & 100,00 & 100,00 \\
\hline AGG/CAA-109 & 13.04 & 50,00 & 31,25 & 24,44 & 33,33 & 27,27 & 23,53 & 28,95 \\
\hline AGG/CAA-125 & 100,00 & 100,00 & 100,00 & 100,00 & 100,00 & 100,00 & 100,00 & 100,00 \\
\hline AGG/CAA-131 & 13,04 & 0,00 & 6,25 & 8.89 & 0,00 & 7,27 & 0,00 & 10,53 \\
\hline AGG/CAA-134 & 91,30 & 100,00 & 75,00 & 86.67 & 100.00 & 89,09 & 94.12 & 86,84 \\
\hline AGG/CAA-141 & 34,78 & 66,67 & 37.50 & 40,00 & 66,67 & 45,45 & 58,82 & 39.47 \\
\hline AGG/CAA-142 & 0,00 & 33,33 & 25,00 & 13,33 & 11,11 & 14,55 & 23,53 & 10,53 \\
\hline AGG/CAA-146 & 100,00 & 100,00 & 100,00 & 100,00 & 100.00 & 100,00 & 100,00 & 100,00 \\
\hline $\mathrm{AGG} / \mathrm{CAA}-149$ & 100,00 & 100,00 & 100.00 & 100.00 & 100.00 & 100,00 & 100,00 & 100,00 \\
\hline AGG/CAA-152 & 100,00 & 100,00 & 100,00 & 100.00 & 100.00 & 100,00 & 100,00 & 100,00 \\
\hline AGG/CAA-163 & 0,00 & 0,00 & 0,00 & 0,00 & 22,22 & 3,64 & 11,76 & 0,00 \\
\hline $\mathrm{AGG} / \mathrm{CAA}-173$ & 100,00 & 100,00 & 100,00 & 100,00 & 100,00 & 100,00 & 100,00 & 100,00 \\
\hline AGG/CAA-181 & 73,91 & 50,00 & 37,50 & 57.78 & 44,44 & 56,36 & 52,94 & 57,89 \\
\hline AGG/CAA-203 & 100,00 & 100,00 & 100,00 & 100.00 & 100,00 & 100,00 & 100,00 & 100,00 \\
\hline AGG/CAA-205 & 4.35 & 16.67 & 0,00 & 4,44 & 0,00 & 3,64 & 0,00 & 5,26 \\
\hline AGG/CAA-209 & 78,26 & 100,00 & 100,00 & 88.89 & 88.89 & 89,09 & 88,24 & 89,47 \\
\hline AGG/CAA-210 & 100,00 & 100,00 & 100,00 & 100.00 & 100,00 & 100,00 & 100,00 & 100,00 \\
\hline AGG/CAA-216 & 47,83 & 66,67 & 56,25 & 53,33 & 77,78 & 58,18 & 64,71 & 55,26 \\
\hline AGG/CAA-265 & 30,43 & 33,33 & 50,00 & 37,78 & 55,56 & 41,82 & 64,71 & 31,58 \\
\hline AGG/CAA-285 & 100,00 & 100,00 & 100,00 & 100,00 & 100,00 & 100,00 & 100,00 & 100,00 \\
\hline AGG/CAA-315 & 39,13 & 50,00 & 50,00 & 44.44 & 0,00 & 36,36 & 5,88 & 50,00 \\
\hline AGG/CAA-327 & 100,00 & 100,00 & 100,00 & 100,00 & 100,00 & 100,00 & 100.00 & 100,00 \\
\hline AGG/CAA-347 & 100,00 & 100,00 & 100,00 & 100,00 & 100.00 & 100,00 & 100,00 & 100,00 \\
\hline
\end{tabular}


Anexo 6 - Freqüência de bandas de 11 microssatẻlites, por grupo de variedades de mandioca

\begin{tabular}{|c|c|c|c|c|c|c|c|c|}
\hline Banda & R. Negro & R. Branco & R. Solimōes & AMAZÓNIA & Litoral SP & TOTAL & Aipins & Bravas \\
\hline GA136-144 & 13,04 & 0,00 & 12.50 & 11,11 & 0,00 & $\begin{array}{r}9,09 \\
\end{array}$ & 0.00 & 13,16 \\
\hline GA136-150 & 39,13 & 50,00 & 37,50 & 40,00 & 100,00 & 50,91 & 92.44 & 34,21 \\
\hline GA136-152 & 0.00 & 0,00 & 6.25 & 2.22 & 0,00 & 1,82 & 0,00 & 2,63 \\
\hline GA136-154 & 21,74 & 50,00 & 50.00 & 35.56 & 11,11 & 32,73 & 31,93 & 34,21 \\
\hline GA136-156 & 47,83 & 0,00 & 0.00 & 24,44 & 0,00 & 20,00 & 0.00 & 28,95 \\
\hline GA136-158 & 65,22 & 83,33 & 81.25 & 73,33 & 77,78 & 72,73 & 81,51 & 71,05 \\
\hline GA126-182 & 73,91 & 100,00 & 100.00 & 86,67 & 33,33 & 78,18 & 63,87 & 86,84 \\
\hline GA126-184 & 8,70 & 16,67 & 6,25 & 8,89 & 66,67 & 18,18 & 62.18 & 0,00 \\
\hline GA126-188 & 30.43 & 16,67 & 25,00 & 26.67 & 33.33 & 27,27 & 24,37 & 28,95 \\
\hline GA126-190 & 0,00 & 0,00 & 6,25 & 2,22 & 0,00 & 1,82 & 0,00 & 2,63 \\
\hline GA126-212 & 43,48 & 0,00 & 6,25 & 24,44 & 33,33 & 27,27 & 23,53 & 28,95 \\
\hline GA126-219 & 8,70 & 16,67 & 37,50 & 20,00 & 22.22 & 20,00 & 31,93 & 15,79 \\
\hline GA012-137 & 95,65 & 50,00 & 81.25 & 84,44 & 77,78 & 83,64 & 94.12 & 81,58 \\
\hline GA012-145 & 30,43 & 50,00 & 43.75 & 37,78 & 88,89 & 47,27 & 59.66 & 42,11 \\
\hline GA012-147 & 34,78 & 50,00 & 25,00 & 33,33 & 11,11 & 29,09 & 39,50 & 26,32 \\
\hline GA131-096 & 13,04 & 50,00 & 62,50 & 35.56 & 66,67 & 40,00 & 68,91 & 28,95 \\
\hline GA131-100 & 4,35 & 0,00 & 0.00 & 2,22 & 0,00 & 1,82 & 0.00 & 2,63 \\
\hline GA131-102 & 26,09 & 0,00 & 25,00 & 22,22 & 0,00 & 18,18 & 0,00 & 26.32 \\
\hline GA131-104 & 13,04 & 0,00 & 0,00 & 6,67 & 0,00 & 5,45 & 0,00 & 7,89 \\
\hline GA131-106 & 8,70 & 33,33 & 18,75 & 15,56 & 55,56 & 23,64 & 68,91 & 5,26 \\
\hline GA131-112 & 0,00 & 16,67 & 0,00 & 2,22 & 0,00 & 1,82 & 0,00 & 2,63 \\
\hline GA131-114 & 60,87 & 33,33 & 31,25 & 46,67 & 0,00 & 38,18 & 0,00 & 55,26 \\
\hline GA131-116 & 65,22 & 50,00 & 50,00 & 57,78 & 77,78 & 61,82 & 60,50 & 63,16 \\
\hline GA134-309 & 52,17 & 50,00 & 6,25 & 35,56 & 55,56 & 38,18 & 63,03 & 28,95 \\
\hline GA134-317 & 86,96 & 100,00 & 100,00 & 93,33 & 100,00 & 94,55 & 105,88 & 92,11 \\
\hline GA134-326 & 13,04 & 0,00 & 0,00 & 6,67 & 0,00 & 5,45 & 0,00 & 7,89 \\
\hline GA013-136 & 4,35 & 0,00 & 0,00 & 2,22 & 0,00 & 1,82 & 0,00 & 2,63 \\
\hline GA013-138 & 100,00 & 100,00 & 100,00 & 100,00 & 100,00 & 100,00 & 105,88 & 100,00 \\
\hline GA140-148 & 4,35 & 16,67 & 0,00 & 4,44 & 44,44 & 12,73 & 36,13 & 2,63 \\
\hline GA140-158 & 47,83 & 33,33 & 12,50 & 33,33 & 33,33 & 32,73 & 37,82 & 31,58 \\
\hline GA140-162 & 34,78 & 50,00 & 68,75 & 48,89 & 100,00 & 58,18 & 99,16 & 42.11 \\
\hline GA140-166 & 30,43 & 16,67 & 18,75 & 24,44 & 0,00 & 20,00 & 0,00 & 28,95 \\
\hline GA140-168 & 0,00 & 33,33 & 37,50 & 17,78 & 22.22 & 18,18 & 25,21 & 15,79 \\
\hline GA140-172 & 65.22 & 0,00 & 50,00 & 51,11 & 0,00 & 41,82 & 0,00 & 60,53 \\
\hline GA021-106 & 0,00 & 50,00 & 0,00 & 6.67 & 0,00 & 5,45 & 0,00 & 7,89 \\
\hline GA021-109 & 4,35 & 0,00 & 0,00 & 2,22 & 0,00 & 1,82 & 0,00 & 2,63 \\
\hline GA021-110 & 13,04 & 0,00 & 0,00 & 6,67 & 0,00 & 5,45 & 0,00 & 7,89 \\
\hline GA021-112 & 30.43 & 33,33 & 43,75 & 35,56 & 77,78 & 43,64 & 94,12 & 23,68 \\
\hline GA021-114 & 95,65 & 66,67 & 75,00 & 84,44 & 33,33 & 74,55 & 51.26 & 86,84 \\
\hline GA021-116 & 0,00 & 16,67 & 0,00 & 2,22 & 88,89 & 18,18 & 52,94 & 2,63 \\
\hline GAGG5-117 & 73,91 & 83,33 & 68,75 & 73,33 & 77,78 & 74,55 & 60,50 & 81,58 \\
\hline GAGG5-119 & 43,48 & 33,33 & 6,25 & 28,89 & 0,00 & 23,64 & 20,17 & 26,32 \\
\hline GAGG5-127 & 30,43 & 33,33 & 56,25 & 40,00 & 100,00 & 49,09 & 100,00 & 28,95 \\
\hline GA057-161 & 21,74 & 50,00 & 62,50 & 40,00 & 33,33 & 38,18 & 37,82 & 39,47 \\
\hline GA057-180 & 95,65 & 66,67 & 75,00 & 84,44 & 77.78 & 83,64 & 80.67 & 86,84 \\
\hline GA057-182 & 8,70 & 0,00 & 6,25 & 6,67 & 0,00 & 5,45 & 0,00 & 7,89 \\
\hline GA057-184 & 17,39 & 50,00 & 12,50 & 20,00 & 55,56 & 27,27 & 68.91 & 10,53 \\
\hline GA016-104 & 100,00 & 83,33 & 100,00 & 97,78 & 88.89 & 96,36 & 100,00 & 97,37 \\
\hline GA016-114 & 26,09 & 50,00 & 37,50 & 33,33 & 77.78 & 40,00 & 74.79 & 26,32 \\
\hline
\end{tabular}


Anexo 7 - Genótipo de cadà variedade de mandioca em 11 locos de microssatélites

\begin{tabular}{|c|c|c|c|c|c|c|c|c|c|c|c|}
\hline Microssatélite & DG038 & DG039 & DG040 & DG041 & DG0 12 & DG043 & DG044 & \begin{tabular}{|l|l}
$\mathrm{DGO} 45$ \\
\end{tabular} & \begin{tabular}{|l|}
$\mathrm{DG} 046$ \\
\end{tabular} & \begin{tabular}{|l|l|} 
DG047 & 1 \\
\end{tabular} & DG048 \\
\hline \multirow[t]{2}{*}{ GA136 } & \begin{tabular}{r|}
154 \\
\end{tabular} & 150 & $\begin{array}{r}158 \\
\end{array}$ & 158 & 150 & 144 & 150 & 150 & 150 & 156 & 156 \\
\hline & 158 & 154 & 158 & 158 & 156 & 158 & 150 & 158 & 156 & 158 & 158 \\
\hline \multirow[t]{2}{*}{ GA126 } & 182 & 188 & 182 & 182 & 212 & 212 & 182 & 182 & 182 & 182 & 182 \\
\hline & 212 & 219 & 182 & 182 & 219 & 212 & 188 & 184 & 182 & 188 & 188 \\
\hline \multirow[t]{2}{*}{ GA012 } & 145 & 137 & 137 & 137 & 137 & 137 & 137 & 137 & 137 & 137 & 137 \\
\hline & 145 & 145 & 137 & 137 & 137 & 147 & 137 & 147 & 147 & 145 & 137 \\
\hline \multirow[t]{2}{*}{ GA131 } & 96 & 116 & 102 & 102 & 102 & 114 & 102 & 96 & 104 & 114 & 102 \\
\hline & 114 & 116 & 114 & 114 & 114 & 116 & 114 & 106 & 116 & 116 & 116 \\
\hline \multirow[t]{2}{*}{ GA134 } & 317 & 309 & 317 & 317 & 309 & 317 & 317 & 309 & 309 & 309 & 309 \\
\hline & 317 & 317 & 326 & 326 & 317 & 317 & 317 & 317 & 317 & 317 & 309 \\
\hline \multirow[t]{2}{*}{ GA013 } & 138 & 138 & 138 & 138 & 138 & 138 & 136 & 138 & 138 & 138 & 138 \\
\hline & 138 & 138 & 138 & 138 & 138 & 138 & 138 & 138 & 138 & 138 & 138 \\
\hline \multirow[t]{2}{*}{ GA140 } & 162 & 148 & 162 & 162 & 162 & 166 & 158 & 158 & 162 & 158 & 166 \\
\hline & 172 & 148 & 166 & 166 & 166 & 172 & 172 & 162 & 172 & 172 & 172 \\
\hline \multirow[t]{2}{*}{ GA021 } & 112 & 112 & 114 & 114 & 112 & 114 & 114 & 112 & 110 & 114 & 112 \\
\hline & 114 & 114 & 114 & 114 & 112 & 114 & 114 & 114 & 114 & 114 & 114 \\
\hline \multirow[t]{2}{*}{ GAGG5 } & 119 & 127 & 117 & 117 & 119 & 117 & 117 & 119 & 117 & 117 & 117 \\
\hline & 127 & 127 & 127 & 127 & 127 & 117 & 119 & 127 & 119 & 119 & 117 \\
\hline \multirow[t]{2}{*}{ GA057 } & 180 & 180 & 161 & 161 & 161 & 180 & 161 & 180 & 180 & 180 & 161 \\
\hline & 180 & 184 & 180 & 180 & 161 & 180 & 180 & 184 & 184 & 180 & 180 \\
\hline \multirow[t]{2}{*}{ GA016 } & 104 & 104 & 104 & 104 & 104 & 104 & 104 & 104 & 104 & 104 & 104 \\
\hline & 104 & 104 & 104 & 104 & 104 & 104 & 114 & 114 & 104 & 104 & 104 \\
\hline
\end{tabular}

Anexo 7 - Genótipo de cada variedade de mandioca em 11 locos de microssatélites

(Continuaçāo)

\begin{tabular}{|c|c|c|c|c|c|c|c|c|c|c|c|}
\hline Microsatélite & DG049 & DG050 & DG051 & DG052 & DG054 & DG055 & DG056 & DG058 & DG059 & DG060 & DG061 \\
\hline \multirow[t]{2}{*}{ GA136 } & 154 & 150 & 144 & 144 & 156 & 154 & 150 & 156 & 154 & 150 & 150 \\
\hline & 156 & 158 & 158 & 158 & 158 & 156 & 158 & 158 & 156 & 156 & 158 \\
\hline \multirow[t]{2}{*}{ GA126 } & 182 & 182 & 212 & 182 & 188 & 188 & 182 & 182 & 182 & 182 & 182 \\
\hline & 212 & 212 & 212 & 212 & 212 & 212 & 188 & 182 & 212 & 182 & 184 \\
\hline \multirow[t]{2}{*}{ GA012 } & 137 & 137 & 137 & 137 & 137 & 137 & 137 & 137 & 137 & 137 & 137 \\
\hline & 137 & 137 & 147 & 147 & 147 & 145 & 147 & 145 & 137 & 145 & 147 \\
\hline \multirow[t]{2}{*}{ GA131 } & 114 & 114 & 114 & 104 & 100 & 114 & 104 & 114 & 114 & 102 & 96 \\
\hline & 116 & 114 & 116 & 116 & 116 & 116 & 116 & 116 & 116 & 116 & 106 \\
\hline \multirow[t]{2}{*}{ GA134 } & 309 & 309 & 317 & 309 & 317 & 317 & 309 & 317 & 309 & 317 & 309 \\
\hline & 309 & 317 & 317 & 317 & 326 & 317 & 317 & 317 & 309 & 317 & 317 \\
\hline \multirow[t]{2}{*}{ GA013 } & 138 & 138 & 138 & 138 & 138 & 138 & 138 & 138 & 138 & 138 & 138 \\
\hline & 138 & 138 & 138 & 138 & 138 & 138 & 138 & 138 & 138 & 138 & 138 \\
\hline \multirow[t]{2}{*}{ GA140 } & 158 & 158 & 166 & 172 & 166 & 158 & 172 & 158 & 158 & 158 & 158 \\
\hline & 172 & 162 & 172 & 172 & 166 & 172 & 172 & 172 & 172 & 172 & 162 \\
\hline \multirow[t]{2}{*}{ GA021 } & 114 & 114 & 114 & 110 & 112 & 109 & 114 & 114 & 114 & 110 & 112 \\
\hline & 114 & 114 & 114 & 114 & 114 & 114 & 114 & 114 & 114 & 114 & 114 \\
\hline \multirow[t]{2}{*}{ GAGG5 } & 117 & 117 & 117 & 117 & 117 & 117 & 119 & 117 & 117 & 117 & 119 \\
\hline & 117 & 117 & 117 & 119 & 117 & 117 & 119 & 117 & 117 & 119 & 127 \\
\hline \multirow[t]{2}{*}{ GA057 } & 180 & 180 & 180 & 180 & 180 & 180 & 180 & 180 & 180 & 180 & 180 \\
\hline & 180 & 180 & 180 & 180 & 180 & 180 & 180 & 182 & 180 & 180 & 184 \\
\hline \multirow[t]{2}{*}{ GA016 } & 104 & 104 & 104 & 104 & 104 & 104 & 104 & 104 & 104 & 104 & 104 \\
\hline & 114 & 114 & 104 & 104 & 104 & 104 & 104 & 104 & 114 & 104 & 114 \\
\hline
\end{tabular}


Anexo 7 - Genótipo de cada variedade de mandioca em 11 locos de microssatélites

(Continuação)

\begin{tabular}{|c|c|c|c|c|c|c|c|c|c|c|c|}
\hline Microsatélite & DG062 & DG065 & DG067 & DG068 & DG069 & DG070 & DG073 & DG111 & DG112 & DG113 & DG114 \\
\hline \multirow[t]{2}{*}{ GA136 } & 156 & 150 & 154 & \begin{tabular}{r|}
150 \\
\end{tabular} & 154 & \begin{tabular}{r|}
150 \\
\end{tabular} & 158 & \begin{tabular}{|l|}
150 \\
\end{tabular} & 154 & 150 & 150 \\
\hline & 158 & 154 & 158 & 158 & 158 & 158 & 158 & 158 & 158 & 158 & 158 \\
\hline \multirow[t]{2}{*}{ GA126 } & 182 & 182 & 182 & 182 & 182 & 182 & 182 & 182 & 182 & 182 & 182 \\
\hline & 182 & 188 & 219 & 184 & 182 & 182 & 182 & 182 & 212 & 182 & 188 \\
\hline \multirow[t]{2}{*}{ GA012 } & 137 & 145 & 147 & 137 & 137 & 137 & 145 & 137 & 145 & 137 & 137 \\
\hline & 145 & 145 & 147 & 147 & 137 & 145 & 147 & 145 & 145 & 145 & 137 \\
\hline \multirow[t]{2}{*}{ GA131 } & 114 & 106 & 96 & 96 & 112 & 96 & 114 & 102 & 96 & 96 & 102 \\
\hline & 116 & 116 & 96 & 106 & 114 & 116 & 116 & 114 & 114 & 114 & 116 \\
\hline \multirow[t]{2}{*}{ GA134 } & 317 & 317 & 309 & 309 & 317 & 317 & 309 & 317 & 317 & 317 & 317 \\
\hline & 317 & 317 & 317 & 317 & 317 & 317 & 317 & 317 & 317 & 317 & 317 \\
\hline \multirow[t]{2}{*}{ GA013 } & 138 & 138 & 138 & 138 & 138 & 138 & 138 & 138 & 138 & 138 & 138 \\
\hline & 138 & 138 & 138 & 138 & 138 & 138 & 138 & 138 & 138 & 138 & 138 \\
\hline \multirow[t]{2}{*}{ GA140 } & 158 & 148 & 162 & 158 & 162 & 158 & 168 & 162 & 162 & 162 & 162 \\
\hline & 172 & 148 & 166 & 162 & 168 & 158 & 168 & 172 & 172 & 172 & 172 \\
\hline \multirow[t]{2}{*}{ GA021 } & 114 & 116 & 112 & 112 & 106 & 106 & 106 & 112 & 112 & 114 & 114 \\
\hline & 114 & 116 & 112 & 114 & 114 & 114 & 114 & 112 & 114 & 114 & 114 \\
\hline \multirow[t]{2}{*}{ GAGG5 } & 117 & 117 & 117 & 119 & 117 & 117 & 117 & 117 & 119 & 117 & 117 \\
\hline & 117 & 117 & 127 & 127 & 119 & 117 & 117 & 117 & 127 & 117 & 117 \\
\hline \multirow[t]{2}{*}{ GA057 } & 180 & 184 & 161 & 180 & 180 & 161 & 161 & 180 & 180 & 180 & 180 \\
\hline & 182 & 184 & 184 & 184 & 180 & 180 & 180 & 180 & 180 & 184 & 180 \\
\hline \multirow[t]{2}{*}{ GA016 } & 104 & 104 & 114 & 104 & 104 & 104 & 104 & 104 & 104 & 104 & 104 \\
\hline & 104 & 104 & 114 & 114 & 114 & 104 & 104 & 114 & 104 & 104 & 114 \\
\hline
\end{tabular}

Anexo 7 - Genótipo de cada variedade de mandioca em 11 locos de microssatélites

(Continuação)

\begin{tabular}{|c|c|c|c|c|c|c|c|c|c|c|c|}
\hline Microsatélite & DG115 & DG116 & DG118 & DG138 & DG117 & DG119 & DG120 & DG121 & DG122 & DG123 & DG124 \\
\hline \multirow[t]{2}{*}{ GA136 } & 152 & 154 & 150 & 154 & 150 & 154 & 154 & 144 & 150 & 144 & 154 \\
\hline & 158 & 154 & 158 & 158 & 158 & 158 & 158 & 158 & 154 & 154 & 158 \\
\hline \multirow[t]{2}{*}{ GA126 } & 182 & 182 & 182 & 182 & 182 & 182 & 182 & 182 & 182 & 182 & 182 \\
\hline & 219 & 182 & 219 & 188 & 219 & 219 & 188 & 219 & 188 & 219 & 184 \\
\hline \multirow[t]{2}{*}{ GA012 } & 137 & 137 & 137 & 137 & 137 & 137 & 137 & 137 & 137 & 147 & 137 \\
\hline & 145 & 145 & 137 & 137 & 137 & 147 & 137 & 145 & 147 & 147 & 147 \\
\hline \multirow[t]{2}{*}{ GA131 } & 96 & 96 & 96 & 96 & 96 & 96 & 96 & 96 & 114 & 114 & 106 \\
\hline & 116 & 116 & 116 & 102 & 116 & 106 & 102 & 116 & 114 & 116 & 106 \\
\hline \multirow[t]{2}{*}{ GA134 } & 317 & 317 & 317 & 317 & 317 & 309 & 317 & 317 & 317 & 317 & 317 \\
\hline & 317 & 317 & 317 & 317 & 317 & 317 & 317 & 317 & 317 & 317 & 317 \\
\hline \multirow[t]{2}{*}{ GA013 } & 138 & 138 & 138 & 138 & 138 & 138 & 138 & 138 & 138 & 138 & 138 \\
\hline & 138 & 138 & 138 & 138 & 138 & 138 & 138 & 138 & 138 & 138 & 138 \\
\hline \multirow[t]{2}{*}{ GA140 } & 168 & 158 & 162 & 162 & 162 & 162 & 162 & 168 & 162 & 366 & 162 \\
\hline & 172 & 166 & 168 & 172 & 168 & 168 & 172 & 172 & 162 & 168 & 162 \\
\hline \multirow[t]{2}{*}{ GA021 } & 114 & 114 & 112 & 114 & 112 & 112 & 114 & 114 & 114 & 112 & 112 \\
\hline & 114 & 114 & 112 & 114 & 112 & 114 & 114 & 114 & 114 & 114 & 112 \\
\hline \multirow[t]{2}{*}{ GAGG5 } & 117 & 127 & 127 & 117 & 127 & 117 & 117 & 117 & 117 & 117 & 117 \\
\hline & 127 & 127 & 127 & 117 & 127 & 127 & 117 & 117 & 117 & 127 & 127 \\
\hline \multirow[t]{2}{*}{ GA057 } & 161 & 180 & 161 & 161 & 161 & 161 & 161 & 161 & 180 & 161 & 161 \\
\hline & 180 & 180 & 180 & 180 & 180 & 161 & 180 & 182 & 180 & 180 & 184 \\
\hline \multirow[t]{2}{*}{ GA016 } & 104 & 104 & 104 & 104 & 104 & 104 & 104 & 104 & 104 & 104 & 104 \\
\hline & 104 & 104 & 114 & 104 & 114 & 114 & 114 & 104 & 104 & 104 & 104 \\
\hline
\end{tabular}


Anexo 7 - Genótipo de cada variedade de mandioca em 11 locos de microssatélites

(Continuação)

\begin{tabular}{|c|c|c|c|c|c|c|c|c|c|c|c|}
\hline Microsatélite & DG125 & DG126 & DG127 & DG128 & DG129 & DG130 & DG131 & DG132 & DG133 & DG134 & DG137 \\
\hline \multirow[t]{2}{*}{ GA136 } & 158 & $\begin{array}{r}150 \\
\end{array}$ & \begin{tabular}{r|}
150 \\
\end{tabular} & 150 & $\begin{array}{r}150 \\
\end{array}$ & 150 & 150 & 150 & 150 & 150 & 150 \\
\hline & 158 & 158 & 150 & 158 & 154 & 158 & 158 & 158 & 158 & 158 & 154 \\
\hline \multirow[t]{2}{*}{ GA126 } & 182 & 184 & 184 & 188 & 184 & 182 & 188 & 182 & 184 & 182 & 182 \\
\hline & 190 & 212 & 212 & 219 & 212 & 184 & 219 & 184 & 188 & 182 & 212 \\
\hline \multirow[t]{2}{*}{ GA012 } & 145 & 145 & 145 & 137 & 137 & 137 & 137 & 137 & 137 & 137 & 137 \\
\hline & 145 & 145 & 145 & 145 & 145 & 145 & 145 & 145 & 145 & 147 & 145 \\
\hline \multirow[t]{2}{*}{ GA131 } & 106 & 106 & 106 & 96 & 96 & 96 & 96 & 96 & 96 & 106 & 106 \\
\hline & 116 & 116 & 116 & 116 & 116 & 106 & 116 & 106 & 116 & 116 & 116 \\
\hline \multirow[t]{2}{*}{ GA134 } & 317 & 309 & 317 & 317 & 317 & 309 & 317 & 309 & 309 & 309 & 317 \\
\hline & 317 & 317 & 317 & 317 & 317 & 317 & 317 & 317 & 317 & 317 & 317 \\
\hline \multirow[t]{2}{*}{ GA013 } & 138 & 138 & 138 & 138 & 138 & 138 & 138 & 138 & 138 & 138 & 138 \\
\hline & 138 & 138 & 138 & 138 & 138 & 138 & 138 & 138 & 138 & 138 & 138 \\
\hline \multirow[t]{2}{*}{ GA140 } & 158 & 148 & 162 & 148 & 162 & 158 & 148 & 158 & 148 & 158 & 148 \\
\hline & 166 & 162 & 168 & 162 & 168 & 162 & 162 & 162 & 162 & 162 & 162 \\
\hline \multirow[t]{2}{*}{ GA021 } & 114 & 112 & 112 & 112 & 114 & 112 & 112 & 112 & 114 & 112 & 112 \\
\hline & 114 & 114 & 116 & 116 & 116 & 116 & 116 & 116 & 116 & 116 & 116 \\
\hline \multirow[t]{2}{*}{ GAGG5 } & 127 & 117 & 117 & 117 & 117 & 127 & 117 & 127 & 117 & 117 & 117 \\
\hline & 127 & 127 & 127 & 127 & 127 & 127 & 127 & 127 & 127 & 127 & 117 \\
\hline \multirow[t]{2}{*}{ GA057 } & 161 & 184 & 180 & 161 & 184 & 180 & 161 & 180 & 161 & 180 & 180 \\
\hline & 161 & 184 & 184 & 180 & 184 & 184 & 180 & 184 & 180 & 180 & 184 \\
\hline \multirow[t]{2}{*}{ GA016 } & 104 & 104 & 104 & 104 & 104 & 104 & 114 & 104 & 104 & 104 & 104 \\
\hline & 104 & 114 & 104 & 114 & 114 & 114 & 114 & 114 & 114 & 104 & 104 \\
\hline
\end{tabular}


Anexo 8 - Frequiência de combinaçães de alelos em 11 locos de microssatélites (em \%)

\begin{tabular}{|c|c|c|c|c|c|c|c|c|}
\hline Alelos & R. Negro & R. Branco & R. Solimōes & AMAZÔNIA & Litoral SP & TOTAL & Aipins & Bravas \\
\hline \multicolumn{9}{|l|}{ GA136 } \\
\hline $144 / 154$ & 0,00 & 0,00 & 6.25 & 2,22 & 0,00 & 1.82 & 0,00 & 2.63 \\
\hline $144 / 158$ & 13.04 & 0,00 & 6.25 & 8,89 & 0,00 & 7,27 & 0,00 & 10,53 \\
\hline $150 / 150$ & 4,35 & 0,00 & 0.00 & 2,22 & 11,11 & 3,64 & 5,88 & 2,63 \\
\hline $150 / 154$ & 4,35 & 16,67 & 6.25 & 6,67 & 11.11 & 9,09 & 17,65 & 5,26 \\
\hline $150 / 156$ & 13,04 & 0.00 & 0.00 & 6.67 & 0,00 & 5,45 & 0,00 & 7,89 \\
\hline $150 / 158$ & 17,39 & 33,33 & 31.25 & 24,44 & 77,78 & 32,73 & 64,71 & 18,42 \\
\hline $152 / 158$ & 0,00 & 0,00 & 6.25 & 2,22 & 0,00 & 1,82 & 0,00 & 2,63 \\
\hline $154 / 154$ & 0,00 & 0,00 & 6.25 & 2.22 & 0,00 & 1,82 & 0,00 & 2,63 \\
\hline $154 / 156$ & 13,04 & 0,00 & 0.00 & 6,67 & 0,00 & 5,45 & 0,00 & 7,89 \\
\hline $154 / 158$ & 4,35 & 33,33 & 31,25 & 17,78 & 0,00 & 14,55 & 11,76 & 15,79 \\
\hline $156 / 158$ & 21,74 & 0,00 & 0.00 & 11,11 & 0,00 & 9,09 & 0,00 & 13,16 \\
\hline $158 / 158$ & 8,70 & 16,67 & 6,25 & 8,89 & 0,00 & 7,27 & 0,00 & 10,53 \\
\hline GA126 & 100,00 & 100,00 & 100,00 & 100,00 & 100,00 & 100,00 & 100,00 & 100,00 \\
\hline $182 / 182$ & 26,09 & 50,00 & 18.75 & 26,67 & 11,11 & 23,64 & 5,88 & 31,58 \\
\hline $182 / 184$ & 8,70 & 16,67 & 6.25 & 8.89 & 22,22 & 10,91 & 35,29 & 0,00 \\
\hline $182 / 188$ & 17,39 & 16.67 & 25.00 & 20,00 & 0,00 & 16,36 & 0,00 & 23,68 \\
\hline $182 / 190$ & 0,00 & 0,00 & 6.25 & 2,22 & 0,00 & 1,82 & 0,00 & 2,63 \\
\hline $182 / 212$ & 21,74 & 0,00 & 6,25 & 13,33 & 0,00 & 12,73 & 5,88 & 15,79 \\
\hline $182 / 219$ & 0,00 & 16,67 & 37.50 & 15,56 & 0,00 & 12,73 & 11,76 & 13,16 \\
\hline $184 / 212$ & 0,00 & 0,00 & 0.00 & 0,00 & 33,33 & 5,45 & 17,65 & 0,00 \\
\hline $184 / 188$ & 0,00 & 0,00 & 0,00 & 0,00 & 11,11 & 1,82 & 5,88 & 0,00 \\
\hline $188 / 212$ & 8,70 & 0,00 & 0,00 & 4,44 & 0.00 & 3,64 & 0,00 & 5,26 \\
\hline $188 / 219$ & 4,35 & 0,00 & 0,00 & 2,22 & 22,22 & 5,45 & 17,65 & 0,00 \\
\hline $212 / 212$ & 8,70 & 0,00 & 0,00 & 4,44 & 0,00 & 3,64 & 0,00 & 5,26 \\
\hline $212 / 219$ & 4,35 & 0,00 & 0,00 & 2,22 & 0,00 & $\begin{array}{r}1,82 \\
\end{array}$ & 0,00 & 2,63 \\
\hline GA012 & 100,00 & 100,00 & 100,00 & 100,00 & 100,00 & 100,00 & 100,00 & 100,00 \\
\hline $137 / 137$ & 34,78 & 16,67 & 31.25 & 31,11 & 0,00 & 25,45 & 5,88 & 34,21 \\
\hline $137 / 145$ & 26,09 & 16,67 & 31.25 & 26,67 & 66,67 & 34,55 & 47,06 & 28,95 \\
\hline $137 / 147$ & 34,78 & 16,67 & 18,75 & 26,67 & 11,11 & 23,64 & 35,29 & 18,42 \\
\hline $145 / 145$ & 4,35 & 16,67 & 12.50 & 8,89 & 22,22 & 10,91 & 11,76 & 10,53 \\
\hline $145 / 147$ & 0,00 & 16,67 & 0.00 & 2.22 & 0,00 & 1,82 & 0,00 & 2,63 \\
\hline $147 / 147$ & 0,00 & 16,67 & 6,25 & 4,44 & 0,00 & 3,64 & 0,00 & 5,26 \\
\hline GA012 & 100,00 & 100,00 & 100,00 & 100,00 & 100,00 & 100,00 & 100,00 & 100,00 \\
\hline $096 / 096$ & 0,00 & 16,67 & 0,00 & 2,22 & 0,00 & 1,82 & 0,00 & 2,63 \\
\hline $096 / 102$ & 0,00 & 0,00 & 12,50 & 4,44 & 0,00 & 3,64 & 0,00 & 5,26 \\
\hline $096 / 106$ & 8,70 & 16,67 & 6,25 & 8,89 & 22,22 & 10,91 & 35,29 & 0,00 \\
\hline $096 / 114$ & 4,35 & 0,00 & 12.50 & 6,67 & 0,00 & 5,45 & 0,00 & 7,89 \\
\hline $096 / 116$ & 0,00 & 16,67 & 31.25 & 13,33 & 44,44 & 18,18 & 29,41 & 13,16 \\
\hline $100 / 116$ & 4,35 & 0,00 & 0,00 & 2,22 & 0,00 & 1,82 & 0,00 & 2,63 \\
\hline $102 / 114$ & 17,39 & 0,00 & 6,25 & 11,11 & 0,00 & 9,09 & 0,00 & 13,16 \\
\hline $102 / 116$ & 8,70 & 0,00 & 6,25 & 6,67 & 0,00 & 5,45 & 0,00 & 7,89 \\
\hline $104 / 116$ & 13,04 & 0,00 & 0,00 & 6,67 & 0,00 & 5,45 & 0,00 & 7,89 \\
\hline $106 / 106$ & 0,00 & 0.00 & 6.25 & 2,22 & 0,00 & 1,82 & 5,88 & 0,00 \\
\hline $106 / 116$ & 0,00 & 16,67 & 6.25 & 4,44 & 33,33 & 10,91 & 23,53 & 5,26 \\
\hline $112 / 114$ & 0,00 & 16,67 & 0.00 & 2.22 & 0,00 & 1,82 & 0,00 & 2,63 \\
\hline $114 / 114$ & 4,35 & 0,00 & 6.25 & 4,44 & 0,00 & 3,64 & 0,00 & 5,26 \\
\hline $114 / 116$ & 34,78 & 16,67 & 6.25 & 22,22 & 0,00 & 18,18 & 0,00 & 26,32 \\
\hline $116 / 116$ & 4,35 & 0,00 & 0.00 & 2,22 & 0,00 & 1,82 & 5,88 & 0,00 \\
\hline GA134 & 100,00 & 100,00 & 100,00 & 100,00 & 100,00 & 100,00 & 100,00 & 100,00 \\
\hline $309 / 309$ & 13,04 & 0,00 & 0.00 & 6,67 & 0,00 & 5,45 & 0,00 & 7,89 \\
\hline $309 / 317$ & 39.13 & 50,00 & 6.25 & 28,89 & 55,56 & 32,73 & 58,82 & 21,05 \\
\hline $317 / 317$ & 34,78 & 50,00 & 93,75 & 57,78 & 44,44 & 56,36 & 41.18 & 63,16 \\
\hline \multirow[t]{2}{*}{$317 / 326$} & 13,04 & 0,00 & 0,00 & 6,67 & 0,00 & 5,45 & 0,00 & 7,89 \\
\hline & 100,00 & 100,00 & 100,00 & 100,00 & 100,00 & 100,00 & 100,00 & 100,00 \\
\hline
\end{tabular}


Anexo 8 - Frequëência de combinações de alelos em 11 locos de microssatélites (continuação)

\begin{tabular}{|c|c|c|c|c|c|c|c|c|}
\hline Alelos & R. Negro & R. Brance & Solimões & AMAZÔNIA & Litoral SP & TOTAL & Aipins & Bravas \\
\hline \multicolumn{9}{|l|}{ GA013 } \\
\hline $136 / 138$ & 4,35 & 0,00 & 0,00 & 2.22 & 0,00 & 1,82 & 0,00 & 2,63 \\
\hline $138 / 138$ & 95,65 & 100,00 & 100,00 & 97,78 & 100.00 & 98,18 & 100,00 & 97,37 \\
\hline GA140 & 100,00 & 100,00 & 100,00 & 100,00 & 100,00 & 100,00 & 100,00 & 100,00 \\
\hline $148 / 148$ & 4,35 & 16,67 & 0,00 & 4,44 & 0,00 & 3,64 & 5,88 & 2,63 \\
\hline $148 / 162$ & 0,00 & 0,00 & 0,00 & 0.00 & 44.44 & 9,09 & 29,41 & 0,00 \\
\hline $158 / 158$ & 0,00 & 16,67 & 0,00 & 2.22 & 0.00 & 1,82 & 0,00 & 2,63 \\
\hline $158 / 162$ & 13,04 & 16,67 & 0.00 & 8.89 & 33,33 & 12,73 & 35,29 & 2,63 \\
\hline $158 / 166$ & 0.00 & 0,00 & 12,50 & 4,44 & 0.00 & 3,64 & 0,00 & 5,26 \\
\hline $158 / 172$ & 34,78 & 0,00 & 0,00 & 17,78 & 0,00 & 14,55 & 0.00 & 21,05 \\
\hline $162 / 162$ & 0,00 & 0,00 & 12,50 & 4.44 & 0,00 & 3,64 & 5,88 & 2,63 \\
\hline $162 / 166$ & 13,04 & 16,67 & 0,00 & 8.89 & 0,00 & 7,27 & 0,00 & 10.53 \\
\hline $162 / 168$ & 0,00 & 16.67 & 18.75 & 8.89 & 22.22 & 10,91 & 23,53 & 5,26 \\
\hline $162 / 172$ & 8,70 & 0,00 & 37,50 & 17,78 & 0,00 & 14,55 & 0,00 & 21,05 \\
\hline $166 / 166$ & 4,35 & 0,00 & 0,00 & 2.22 & 0.00 & 1,82 & 0,00 & 2,63 \\
\hline $166 / 168$ & 0,00 & 0,00 & 6,25 & 2.22 & 0,00 & 1,82 & 0,00 & 2,63 \\
\hline $166 / 172$ & 13,04 & 0,00 & 0,00 & 6,67 & 0.00 & 5,45 & 0,00 & 7,89 \\
\hline $168 / 168$ & 0,00 & 16,67 & 0,00 & 2,22 & 0.00 & 1,82 & 0,00 & 2,63 \\
\hline $168 / 172$ & 0,00 & 0,00 & 12,50 & 4,44 & 0.00 & 3,64 & 0,00 & 5,26 \\
\hline $172 / 172$ & 8,70 & 0.00 & 0,00 & 4,44 & 0,00 & 3,64 & 0,00 & 5.26 \\
\hline GA021 & 100,00 & 100,00 & 100,00 & 100,00 & 100,00 & 100,00 & 100,00 & 100,00 \\
\hline $106 / 114$ & 0,00 & 50,00 & 0,00 & 6,67 & 0,00 & 5,45 & 0,00 & 7,89 \\
\hline $109 / 114$ & 4,35 & 0,00 & 0,00 & 2,22 & 0,00 & 1,82 & 0,00 & 2,63 \\
\hline $110 / 114$ & 13,04 & 0,00 & 0,00 & 6,67 & 0,00 & 5,45 & 0,00 & 7,89 \\
\hline $112 / 112$ & 4,35 & 16,67 & 25,00 & 13,33 & 0.00 & 10,91 & 11,76 & 10,53 \\
\hline $112 / 114$ & 26,09 & 16,67 & 18,75 & 22,22 & 11,11 & 20,00 & 35,29 & 13,16 \\
\hline $112 / 116$ & 0,00 & 0,00 & 0,00 & 0,00 & 66,67 & 12,73 & 41,18 & 0,00 \\
\hline $114 / 114$ & 52,17 & 0,00 & 56,25 & 46,67 & 0,00 & 38,18 & 0,00 & 55,26 \\
\hline $114 / 116$ & 0,00 & 0,00 & 0,00 & 0.00 & 22,22 & 3,64 & 11,76 & 0,00 \\
\hline $116 / 116$ & 0,00 & 16,67 & 0,00 & 2,22 & 0,00 & 1,82 & 0,00 & 2,63 \\
\hline GAGG5 & 100,00 & 100,00 & 100,00 & 100,00 & 100,00 & 100,00 & 100,00 & 100,00 \\
\hline $117 / 117$ & 43,48 & 50,00 & 43,75 & 44,44 & 0,00 & 38,18 & 5,88 & 52,63 \\
\hline $117 / 119$ & 21,74 & 16,67 & 0,00 & 13,33 & 0,00 & 10,91 & 0,00 & 15,79 \\
\hline $117 / 127$ & 8,70 & 16,67 & 25,00 & 15,56 & 77,78 & 25,45 & 52,94 & 13,16 \\
\hline $119 / 119$ & 4,35 & 0,00 & 0,00 & 2,22 & 0,00 & 1,82 & 0,00 & 2,63 \\
\hline $119 / 127$ & 17,39 & 16,67 & 6,25 & 13,33 & 0.00 & 10,91 & 17,65 & 7,89 \\
\hline $127 / 127$ & 4,35 & 0,00 & 25,00 & 11,11 & 22,22 & 12,73 & 23,53 & 7,89 \\
\hline GA057 & 100,00 & 100,00 & 100,00 & 100,00 & 100,00 & 100,00 & 100,00 & 100,00 \\
\hline $161 / 161$ & 4,35 & 0,00 & 12,50 & 6.67 & 0,00 & 5,45 & 5,88 & 5,26 \\
\hline $161 / 180$ & 17,39 & 33,33 & 37,50 & 26,67 & 33,33 & 27,27 & 23,53 & 28,95 \\
\hline $161 / 182$ & 0,00 & 0,00 & 6,25 & 2,22 & 0,00 & 1,82 & 0,00 & 2,63 \\
\hline $161 / 184$ & 0,00 & 16,67 & 6,25 & 4,44 & 0,00 & 3,64 & 5,88 & 2,63 \\
\hline $180 / 180$ & 52,17 & 16,67 & 31,25 & 40,00 & 11,11 & 34,55 & 5,88 & 47,37 \\
\hline $180 / 182$ & 8,70 & 0,00 & 0.00 & 4,44 & 0,00 & 3,64 & 0,00 & 5,26 \\
\hline $180 / 184$ & 17,39 & 16,67 & 6,25 & 13,33 & 33,33 & 18,18 & 47,06 & 5,26 \\
\hline $184 / 184$ & 0,00 & 16,67 & 0,00 & 2,22 & 22,22 & 5,45 & 11,76 & 2,63 \\
\hline GA016 & 100,00 & 100,00 & 100,00 & 100,00 & 100,00 & 100,00 & 100,00 & 100,00 \\
\hline $104 / 104$ & 73,91 & 50,00 & 62,50 & 66,67 & 22,22 & 60,00 & 29,41 & 73,68 \\
\hline $104 / 114$ & 26,09 & 33,33 & 37,50 & 31,11 & 66,67 & 36,36 & 64,71 & 23,68 \\
\hline $114 / 114$ & 0,00 & 16,67 & 0,00 & 2,22 & 11,11 & 3,64 & 5,88 & 2,63 \\
\hline & 100,00 & 100,00 & 100,00 & 100,00 & 100,00 & 100,00 & 100,00 & 100,00 \\
\hline
\end{tabular}



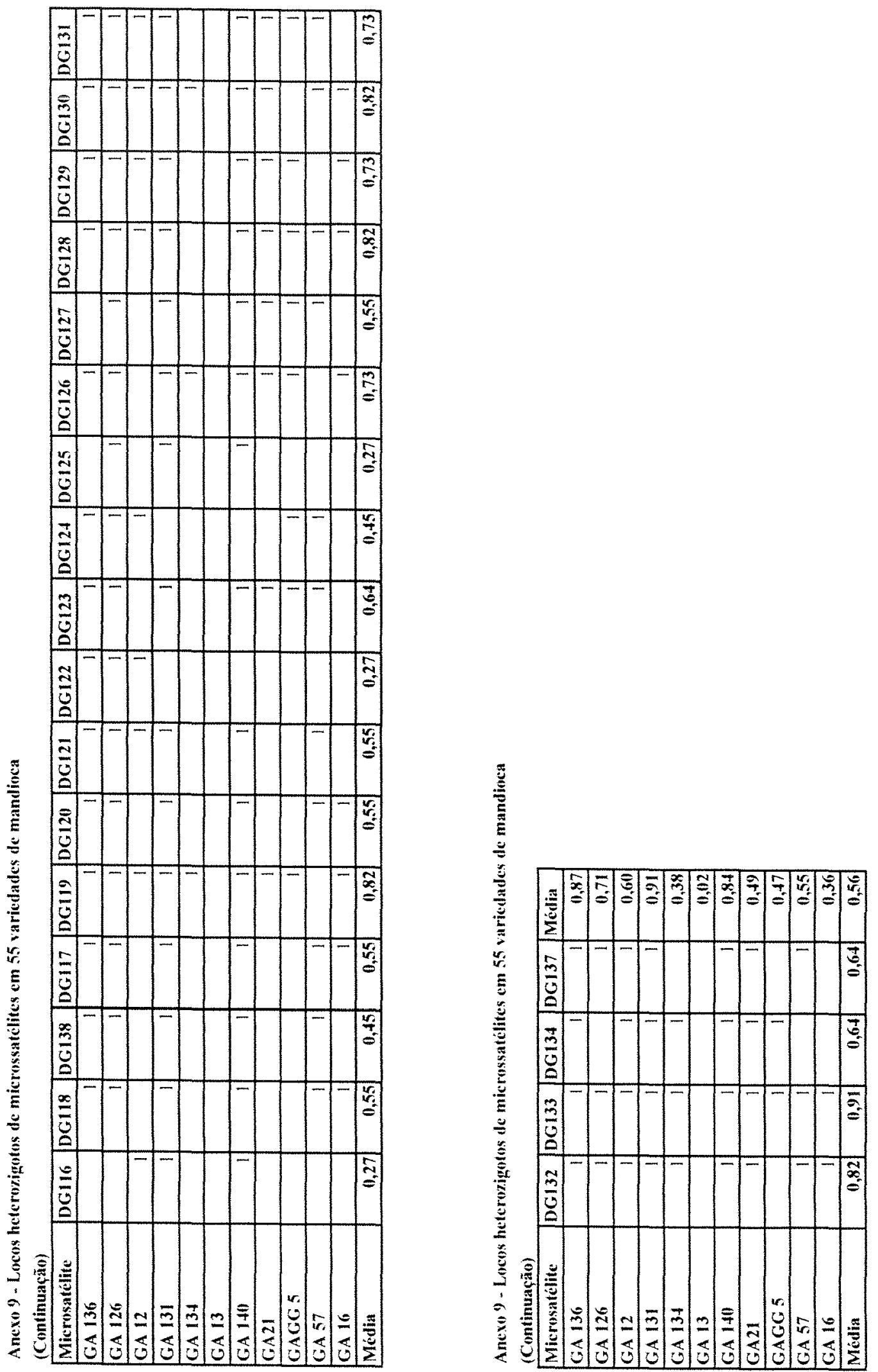

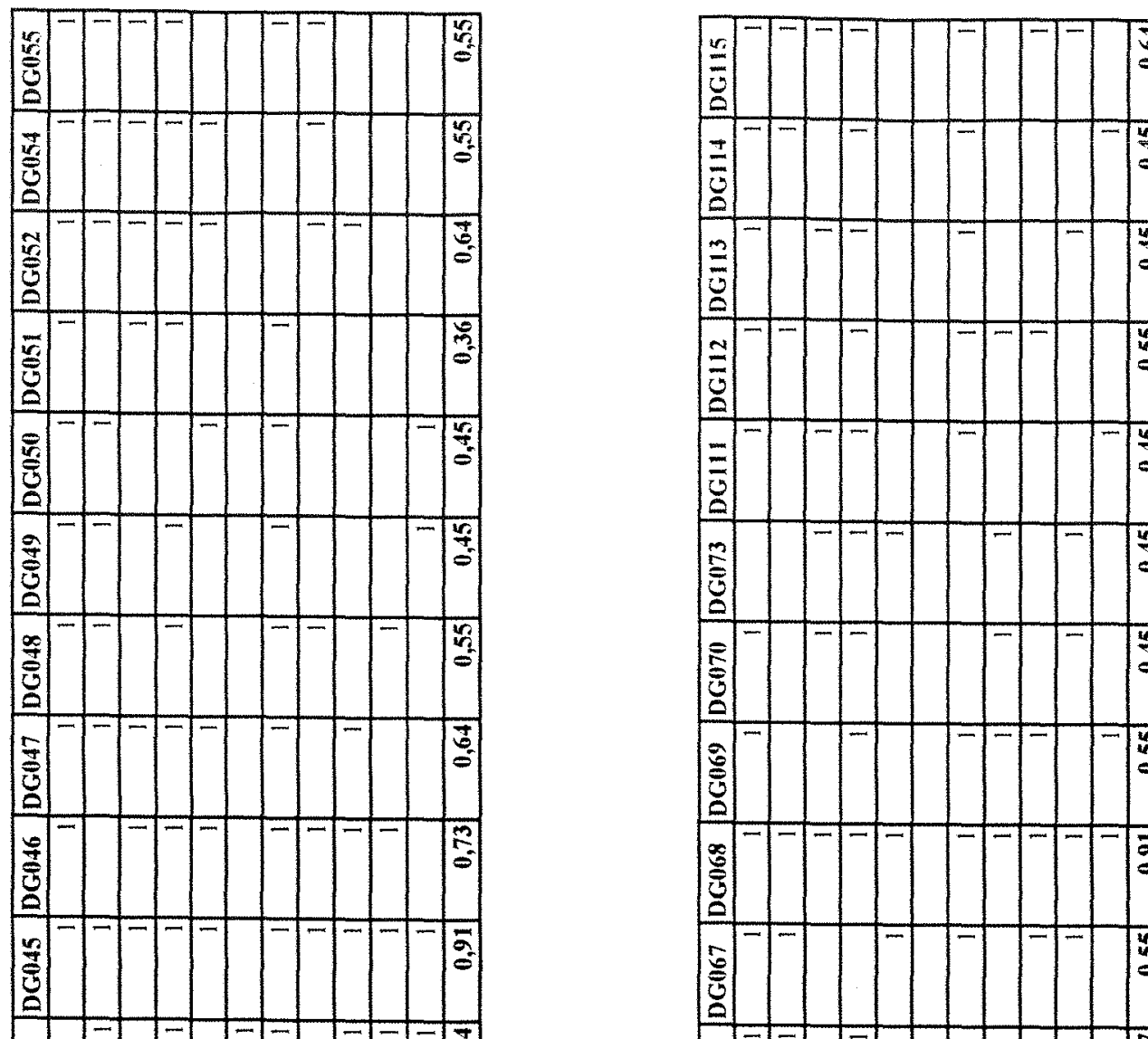

$\frac{2}{5}$



寒

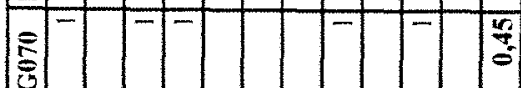

5
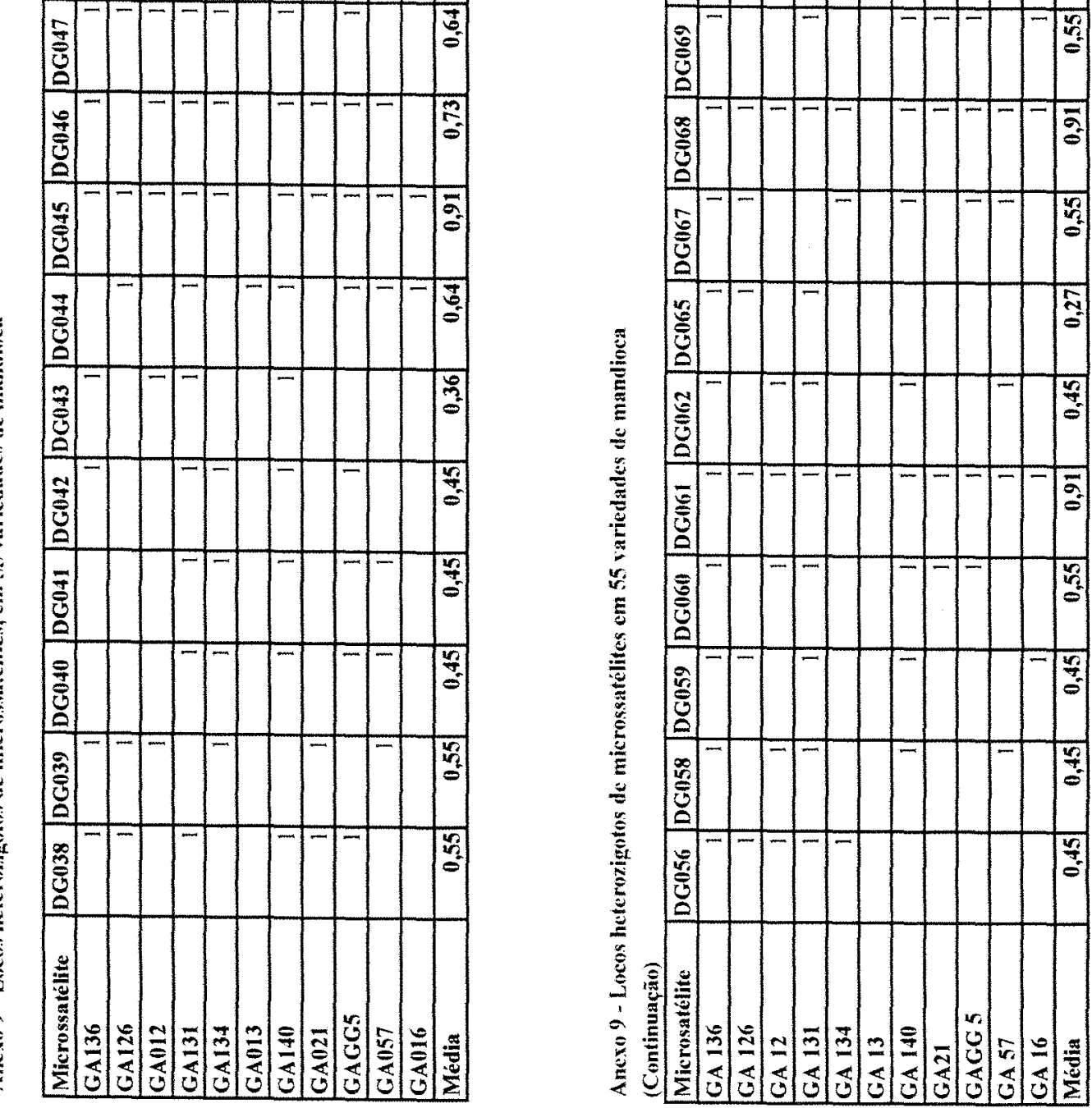
Anexo 10 - Indices de similaridade (Nei $\&$ Li) entre 55 variedades de mandioca,

a partir de 156 bandas de RAPD

\begin{tabular}{|c|c|c|c|c|c|c|c|c|c|c|c|c|}
\hline & DG038 & DG039 & DG040 & DG041 & $D G 042$ & DG043 & DG044 & DG045 & $D G 046$ & DG047 & DG048 & DG049 \\
\hline DG038 & 1,00 & & & & & & & & & & & \\
\hline DG039 & 0.85 & 1.00 & & & & & & & & & & \\
\hline DG040 & 0.89 & 0,86 & 1,00 & & & & & & & & & \\
\hline DG041 & 0,89 & 0.87 & 0.99 & 1,00 & & & & & & & & \\
\hline $\mathrm{DG} 042$ & 0.88 & 0,85 & 0.88 & 0,87 & 1,00 & & & & & & & \\
\hline DG043 & 0.88 & 0,89 & 0.91 & 0.90 & 0,87 & 1,00 & & & & & & \\
\hline DG044 & 0.88 & 0.88 & 0.90 & 0,90 & 0.89 & 0,89 & 1.00 & & & & & \\
\hline DG045 & 0,85 & 0,94 & 0.86 & 0.87 & 0,86 & 0.88 & 0.88 & 1,00 & & & & \\
\hline DG046 & 0.93 & 0,88 & 0.87 & 0.89 & 0,88 & 0.88 & 0.89 & 0,86 & 1.00 & & & \\
\hline DG047 & 0,91 & 0,87 & 0.93 & 0,93 & 0.89 & 0.87 & 0.90 & 0.89 & 0.90 & 1,00 & & \\
\hline DG048 & 0,90 & 0,87 & 0,91 & 0,92 & 0,89 & 0,91 & 0,91 & 0.85 & 0.89 & 0,91 & 1,00 & \\
\hline DG049 & 0,89 & 0,88 & 0,89 & 0,89 & 0,87 & 0.89 & 0.91 & 0,89 & 0.91 & 0,92 & 0,91 & 1,00 \\
\hline DG050 & 0,91 & 0,91 & 0,89 & 0,90 & 0,84 & 0,88 & 0.87 & 0,89 & 0.91 & 0,90 & 0,89 & 0,88 \\
\hline DG051 & 0,88 & 0,90 & 0.91 & 0,91 & 0,85 & 0,97 & 0.89 & 0,88 & 0.88 & 0.88 & 0.90 & 0,88 \\
\hline DG052 & 0,93 & 0,88 & 0.91 & 0,92 & 0,89 & 0.88 & 0.89 & 0.85 & 0.92 & 0,90 & 0.91 & 0.91 \\
\hline DG054 & 0,93 & 0,88 & 0.89 & 0.90 & 0,86 & 0,89 & 0.91 & 0,88 & 0.92 & 0.92 & 0,91 & 0,90 \\
\hline DG055 & 0,91 & 0,89 & 0,92 & 0,93 & 0,85 & 0,88 & 0.90 & 0.89 & 0.90 & 0,91 & 0,88 & 0,89 \\
\hline DG056 & 0.92 & 0.88 & 0,91 & 0.91 & 0,89 & 0.87 & 0.91 & 0.86 & 0.92 & 0.92 & 0.89 & 0,91 \\
\hline DG058 & 0,92 & 0.86 & 0,91 & 0,91 & 0,86 & 0.89 & 0.88 & 0.87 & 0.90 & 0.92 & 0,88 & 0,89 \\
\hline DG059 & 0,90 & 0,90 & 0.89 & 0,90 & 0.86 & 0,87 & 0.92 & 0.89 & 0,91 & 0,92 & 0,92 & 0,98 \\
\hline DG060 & 0,91 & 0,91 & 0,89 & 0,90 & 0,89 & 0,90 & 0,90 & 0,88 & 0.93 & 0,90 & 0,93 & 0,92 \\
\hline DG061 & 0,86 & 0,91 & 0,84 & 0,85 & 0,84 & 0,84 & 0.88 & 0,89 & 0.87 & 0,85 & 0,86 & 0.88 \\
\hline DG062 & 0,92 & 0,87 & 0,89 & 0,90 & 0,85 & 0,89 & 0.88 & 0,87 & 0,91 & 0,90 & 0,89 & 0,87 \\
\hline DG065 & 0,90 & 0,91 & 0,88 & 0,89 & 0,86 & 0,87 & 0,91 & 0.89 & 0.91 & 0,91 & 0,90 & 0,90 \\
\hline DG067 & 0,87 & 0,91 & 0,85 & 0,86 & 0,85 & 0,85 & 0,89 & 0,90 & 0.88 & 0,86 & 0,87 & 0,89 \\
\hline DG068 & 0,85 & 0,93 & 0,84 & 0,85 & 0,84 & 0,86 & 0,87 & 0,99 & 0.86 & 0,88 & 0,84 & 0,87 \\
\hline DG069 & 0,85 & 0,85 & 0,85 & 0,86 & 0,86 & 0,83 & 0.88 & 0,85 & 0.84 & 0.87 & 0,85 & 0,83 \\
\hline DG070 & 0,87 & 0,86 & 0,87 & 0,87 & 0,86 & 0.86 & 0,88 & 0,85 & 0,84 & 0.88 & 0.84 & 0,85 \\
\hline DG073 & 0,89 & 0.91 & 0,89 & 0,89 & 0,85 & 0,87 & 0.89 & 0,90 & 0,89 & 0,90 & 0,88 & 0,89 \\
\hline DG111 & 0,94 & 0,90 & 0,94 & 0,94 & 0,88 & 0,89 & 0.90 & 0,89 & 0.89 & 0,91 & 0,88 & 0,87 \\
\hline DG112 & 0,98 & 0,87 & 0,88 & 0,88 & 0,86 & 0.89 & 0,89 & 0,86 & 0.92 & 0,89 & 0,88 & 0,88 \\
\hline DG113 & 0,92 & 0,88 & 0.91 & 0,92 & 0.88 & 0,89 & 0.90 & 0,88 & 0.91 & 0.91 & 0,88 & 0,88 \\
\hline DG114 & 0,86 & 0.85 & 0,86 & 0,87 & 0,86 & 0,83 & 0.84 & 0,87 & 0,87 & 0,85 & 0,82 & 0.81 \\
\hline DG115 & 0,91 & 0,87 & 0.91 & 0.92 & 0,89 & 0,88 & 0.91 & 0,86 & 0.89 & 0.91 & 0,90 & 0,89 \\
\hline DG116 & 0,88 & 0,85 & 0.86 & 0,87 & 0,87 & 0,83 & 0,83 & 0.84 & 0.86 & 0.87 & 0,83 & 0,83 \\
\hline DG118 & 0,87 & 0,90 & 0,87 & 0,86 & 0,82 & 0,86 & 0,83 & 0,92 & 0.87 & 0,87 & 0,84 & 0,85 \\
\hline DG138 & 0,90 & 0,87 & 0,88 & 0,88 & 0,87 & 0,87 & 0.91 & 0,87 & 0,89 & 0,90 & 0,87 & 0,89 \\
\hline DG117 & 0,87 & 0,90 & 0.86 & 0,86 & 0,82 & 0,85 & 0,84 & 0,91 & 0.88 & 0,86 & 0,84 & 0,85 \\
\hline DG119 & 0.87 & 0,93 & 0,86 & 0,87 & 0,83 & 0.88 & 0,88 & 0,92 & 0.88 & 0,86 & 0,87 & 0,88 \\
\hline DG120 & 0,91 & 0,87 & 0,88 & 0,89 & 0,87 & 0,87 & 0,91 & 0,86 & 0,89 & 0,90 & 0,88 & 0,89 \\
\hline DG121 & 0,90 & 0,91 & 0,90 & 0,91 & 0,86 & 0,89 & 0,91 & 0,91 & 0.88 & 0,92 & 0,89 & 0,90 \\
\hline DG122 & 0,88 & 0,89 & 0,86 & 0,87 & 0,85 & 0,85 & 0,90 & 0,86 & 0.86 & 0,88 & 0,88 & 0,88 \\
\hline DG123 & 0.85 & 0,83 & 0,85 & 0,85 & 0.87 & 0,84 & 0,85 & 0,85 & 0.88 & 0.87 & 0.82 & 0,84 \\
\hline DG124 & 0,88 & 0,91 & 0.86 & 0,86 & 0,84 & 0,87 & 0.86 & 0,91 & 0,87 & 0,85 & 0,85 & 0,86 \\
\hline DG125 & 0,85 & 0,85 & 0,85 & 0,86 & 0,87 & 0,84 & 0,86 & 0,86 & 0.88 & 0,88 & 0,84 & 0,85 \\
\hline DG126 & 0,87 & 0,93 & 0.87 & 0,86 & 0,86 & 0.89 & 0.87 & 0.93 & 0.89 & 0.88 & 0,85 & 0,88 \\
\hline DG127 & 0,86 & 0,91 & 0,85 & 0.86 & 0.84 & 0,89 & 0.84 & 0.89 & 0,89 & 0,86 & 0,88 & 0,87 \\
\hline DG128 & 0,87 & 0,94 & 0.86 & 0,87 & 0.86 & 0,87 & 0.89 & 0,92 & 0,88 & 0,89 & 0.88 & 0,89 \\
\hline DG129 & 0,87 & 0,92 & 0.86 & 0,86 & 0.84 & 0,88 & 0.86 & 0,91 & 0.89 & 0.86 & 0.86 & 0,87 \\
\hline DG130 & 0.88 & 0,94 & 0,85 & 0,86 & 0.85 & 0.89 & 0.85 & 0,91 & 0.89 & 0,87 & 0.86 & 0,87 \\
\hline DG131 & 0.86 & 0.94 & 0,85 & 0,86 & 0,85 & 0,87 & 0.88 & 0,89 & 0,89 & 0,87 & 0,87 & 0,88 \\
\hline DG132 & 0,88 & 0.95 & 0.84 & 0.85 & 0.84 & 0,87 & 0.86 & 0.91 & 0,88 & 0,86 & 0,87 & 0,87 \\
\hline DG133 & 0,87 & 0,93 & 0.86 & 0.86 & 0,84 & 0.88 & 0.86 & 0,90 & 0.87 & 0.87 & 0,85 & 0.87 \\
\hline DG134 & 0.85 & 0,89 & 0.85 & 0.86 & 0,87 & 0,84 & 0.85 & 0,90 & 0,88 & 0.87 & 0.84 & 0,86 \\
\hline DG137 & 0,86 & 0,94 & 0.86 & 0.86 & 0.84 & 0,88 & 0.88 & 0.91 & 0.88 & 0,88 & 0,86 & 0.89 \\
\hline
\end{tabular}


Anexo 10 - Indices de similaridade (Nei \& Li) entre 55 variedades de mandioca,

a partir de 156 bandas de RAPD (Continuação)

\begin{tabular}{|c|c|c|c|c|c|c|c|c|c|c|c|c|}
\hline & DG050 & DG051 & DG052 & DG054 & $10 G 055$ & DG056 & DG058 & DG059 & DG060 & DG061 & $1 \mathrm{DG} 062$ & $\mathrm{DG} 065$ \\
\hline \multicolumn{13}{|l|}{ DG038 } \\
\hline \multicolumn{13}{|l|}{ DG039 } \\
\hline \multicolumn{13}{|l|}{ DGo40 } \\
\hline \multicolumn{13}{|l|}{ DG041 } \\
\hline \multicolumn{13}{|l|}{$\mathrm{DG} 042$} \\
\hline \multicolumn{13}{|l|}{ DG043 } \\
\hline \multicolumn{13}{|l|}{ DG044 } \\
\hline \multicolumn{13}{|l|}{ DG045 } \\
\hline \multicolumn{13}{|l|}{ DG046 } \\
\hline \multicolumn{13}{|l|}{\begin{tabular}{|l}
$D G 047$ \\
\end{tabular}} \\
\hline \multicolumn{13}{|l|}{ DG048 } \\
\hline \multicolumn{13}{|l|}{ DG049 } \\
\hline DG050 & 1,00 & & & & & & & & & & & \\
\hline DG051 & 0.90 & 1,00 & & & & & & & & & & \\
\hline DG052 & 0,89 & 0,89 & 1,00 & & & & & & & & & \\
\hline DG054 & 0,90 & 0,90 & 0,93 & 1,00 & & & & & & & & \\
\hline DG055 & 0.89 & 0.90 & 0,92 & 0,93 & 1.00 & & & & & & & \\
\hline DG056 & 0.90 & 0.86 & 0,93 & 0.90 & 0.90 & 1.00 & & & & & & \\
\hline DG058 & 0.90 & 0,90 & 0,91 & 0,93 & 0.94 & 0.91 & 1.00 & & & & & \\
\hline DG059 & 0,90 & 0.89 & 0,91 & 0,92 & 0.91 & 0,91 & 0,90 & 1,00 & & & & \\
\hline DG060 & 0,92 & 0,92 & 0,96 & 0,94 & 0,92 & 0.92 & 0,91 & 0,93 & 1,00 & & & \\
\hline DG061 & 0,90 & 0,86 & 0,88 & 0,89 & 0,87 & 0,88 & 0.86 & 0,90 & 0,90 & 1,00 & & \\
\hline DG062 & 0,89 & 0,90 & 0,91 & 0,93 & 0,93 & 0,90 & 0,98 & 0.89 & 0,90 & 0,86 & 1.00 & \\
\hline DG065 & 0,93 & 0,88 & 0,90 & 0,91 & 0,90 & 0,90 & 0,89 & 0,93 & 0,94 & 0,91 & 0,88 & 1,00 \\
\hline DG067 & 0,89 & 0,87 & 0,88 & 0,89 & 0,88 & 0,89 & 0,87 & 0.91 & 0,91 & 0,99 & 0,86 & 0,91 \\
\hline DG068 & 0,89 & 0,87 & 0,84 & 0,88 & 0,89 & 0,84 & 0,86 & 0.89 & 0,88 & 0,90 & 0,86 & 0,90 \\
\hline DG069 & 0,84 & 0,85 & 0,87 & 0,87 & 0,87 & 0.87 & 0,84 & 0,85 & 0,87 & 0,85 & 0,84 & 0,88 \\
\hline DG070 & 0,86 & 0,86 & 0,87 & 0,88 & 0,89 & 0.89 & 0,89 & 0,85 & 0,88 & 0,85 & 0,87 & 0,88 \\
\hline DG073 & 0,88 & 0,87 & 0,90 & 0,89 & 0,88 & 0,91 & 0,90 & 0,90 & 0.92 & 0,87 & 0,88 & 0,92 \\
\hline DG111 & 0,91 & 0,90 & 0,92 & 0,91 & 0,93 & 0,90 & 0,92 & 0,89 & 0,91 & 0,87 & 0,90 & 0,91 \\
\hline DG112 & 0.91 & 0,89 & 0,91 & 0,93 & 0,91 & 0,90 & 0,93 & 0.89 & 0,91 & 0,86 & 0,92 & 0,89 \\
\hline DG113 & 0.91 & 0,90 & 0,92 & 0,92 & 0.93 & 0.89 & 0,92 & 0,89 & 0,93 & 0,88 & 0,92 & 0,93 \\
\hline DG114 & 0.86 & 0,84 & 0,86 & 0.86 & 0,87 & 0,86 & 0,87 & 0.81 & 0.85 & 0,83 & 0.88 & 0,84 \\
\hline DG115 & 0,89 & 0.88 & 0,92 & 0,93 & 0,91 & 0,90 & 0.92 & 0.90 & 0,92 & 0,86 & 0.92 & 0,92 \\
\hline DG116 & 0.86 & 0,84 & 0,88 & 0,88 & 0,86 & 0,87 & 0,87 & 0,85 & 0,88 & 0,84 & 0,86 & 0,87 \\
\hline DG118 & 0,89 & 0.87 & 0,85 & 0,87 & 0,89 & 0,87 & 0,87 & 0,86 & 0,88 & 0.87 & 0,87 & 0,89 \\
\hline DG138 & 0,90 & 0,88 & 0,89 & 0,92 & 0.89 & 0,89 & 0,90 & 0,89 & 0.92 & 0,88 & 0,88 & 0,92 \\
\hline DG117 & 0,89 & 0,88 & 0,86 & 0,88 & 0,89 & 0,86 & 0,87 & 0,87 & 0,88 & 0,89 & 0,87 & 0,88 \\
\hline DG119 & 0,91 & 0,89 & 0,88 & 0,88 & 0,88 & 0,88 & 0,88 & 0,89 & 0,89 & 0,93 & 0,89 & 0,89 \\
\hline DG120 & $0,9]$ & 0,88 & 0,90 & 0,92 & 0,89 & 0.89 & 0,90 & 0,90 & 0,92 & 0,88 & 0.89 & 0,94 \\
\hline DG121 & 0,89 & 0,91 & 0,90 & 0,92 & 0,92 & 0,90 & 0,91 & 0,92 & 0,92 & 0,89 & 0,91 & 0,92 \\
\hline DG122 & 0,86 & 0.85 & 0,89 & 0,89 & 0,90 & 0,88 & 0,87 & 0,88 & 0,90 & 0,86 & 0,88 & 0,90 \\
\hline DG123 & 0,83 & 0,84 & 0,87 & 0,88 & 0,85 & 0,87 & 0,88 & 0,83 & 0,87 & 0,83 & 0,87 & 0,84 \\
\hline DG124 & 0,88 & 0,89 & 0,86 & 0,88 & 0,88 & 0,86 & 0.88 & 0,88 & 0,88 & 0,91 & 0,88 & 0,87 \\
\hline DG125 & 0.84 & 0,85 & 0.88 & 0,87 & 0,86 & 0,86 & 0,87 & 0,85 & 0,88 & 0,84 & 0,87 & 0,86 \\
\hline DG126 & 0,89 & 0,88 & 0,87 & 0,87 & 0,88 & 0,87 & 0,86 & 0,87 & 0.89 & 0,91 & 0,85 & 0,90 \\
\hline DG127 & 0,85 & 0,89 & 0,88 & 0,86 & 0,88 & 0.87 & 0.88 & 0.87 & 0.91 & 0,87 & 0,89 & 0,87 \\
\hline DG128 & 0,89 & 0.88 & 0,89 & 0,90 & 0,90 & 0,89 & 0.88 & 0,90 & 0,90 & 0,89 & 0,88 & 0,89 \\
\hline DG129 & 0,89 & 0,88 & 0,87 & 0,87 & 0.88 & 0,88 & 0,89 & 0,87 & 0,90 & 0,91 & 0,88 & 0,90 \\
\hline \begin{tabular}{|l} 
DG130 \\
\end{tabular} & 0,89 & 0,89 & 0,88 & 0,88 & 0.88 & 0.88 & 0,89 & 0,87 & 0.91 & 0,92 & 0,88 & 0,91 \\
\hline DG131 & 0,88 & 0,89 & 0,89 & 0,90 & 0,90 & 0,88 & 0,89 & 0,89 & 0.91 & 0,89 & 0,90 & 0,89 \\
\hline DG132 & 0,89 & 0,88 & 0,87 & 0.88 & 0,88 & 0,87 & 0,88 & 0,88 & $0,9]$ & 0,92 & 0,88 & 0,91 \\
\hline DG133 & 0.86 & 0,87 & 0,87 & 0,87 & 0,88 & 0.87 & 0.87 & 0.87 & 0,87 & 0,87 & 0,87 & 0,87 \\
\hline DG134 & 0,88 & 0,85 & 0,86 & 0,86 & 0,89 & 0,85 & 0.87 & 0.87 & 0.88 & 0,88 & 0,87 & 0,90 \\
\hline DG137 & 0,90 & 0,89 & 0,87 & 0.90 & 0.89 & 0.88 & 0.88 & 0,91 & 0,90 & 0,92 & 0,87 & 0,92 \\
\hline
\end{tabular}


Anexo 10 - Índices de similaridade (Nei \& Li) entre 55 variedades de mandioca,

a partir de 156 bandas de RAPD (Continuação)

\begin{tabular}{|c|c|c|c|c|c|c|c|c|c|c|c|c|}
\hline & DG067 & DG068 & DG069 & DG070 & DG073 & DG111 & DG112 & DG113 & DG114 & DG115 & DG116 & DG118 \\
\hline \multicolumn{13}{|l|}{ DG038 } \\
\hline \multicolumn{13}{|l|}{ DG039 } \\
\hline \multicolumn{13}{|l|}{ DG040 } \\
\hline \multicolumn{13}{|l|}{ DG041 } \\
\hline \multicolumn{13}{|l|}{ DG042 } \\
\hline \multicolumn{13}{|l|}{ DG043 } \\
\hline \multicolumn{13}{|l|}{ DG044 } \\
\hline \multicolumn{13}{|l|}{ DG045 } \\
\hline \multicolumn{13}{|l|}{ DG046 } \\
\hline \multicolumn{13}{|l|}{ DG047 } \\
\hline \multicolumn{13}{|l|}{ DG048 } \\
\hline \multicolumn{13}{|l|}{ DG049 } \\
\hline \multicolumn{13}{|l|}{ DG050 } \\
\hline \multicolumn{13}{|l|}{ DG051 } \\
\hline \multicolumn{13}{|l|}{ DG052 } \\
\hline DG054 & & & & & & & & & & & & \\
\hline DG055 & & & & & & & & & & & & \\
\hline DG056 & & & & & & & & & & & & \\
\hline DG058 & & & & & & & & & & & & \\
\hline DG059 & & & & & & & & & & & & \\
\hline DG060 & & & & & & & & & & & & \\
\hline DG061 & & & & & & & & & & & & \\
\hline DG062 & & & & & & & & & & & & \\
\hline DG065 & & & & & & & & & & & & \\
\hline DG067 & 1,00 & & & & & & & & & & & \\
\hline DG068 & 0,90 & 1,00 & & & & & & & & & & \\
\hline DG069 & 0,86 & 0,86 & 1,00 & & & & & & & & & \\
\hline DG070 & 0,85 & 0,85 & 0,89 & 1,00 & & & & & & & & \\
\hline DG073 & 0,87 & 0,89 & 0.85 & 0,88 & 1,00 & & & & & & & \\
\hline DG111 & 0,87 & 0,89 & 0.87 & 0,88 & 0,91 & 1,00 & & & & & & \\
\hline DG112 & 0,87 & 0.86 & 0.83 & 0,88 & 0,89 & 0,93 & 1,00 & & & & & \\
\hline DG113 & 0,88 & 0.88 & 0.85 & 0,88 & 0,91 & 0.94 & 0,92 & 1,00 & & & & \\
\hline DG114 & 0.84 & 0,87 & 0.89 & 0,90 & 0,86 & 0,89 & 0.87 & 0,87 & 1,00 & & & \\
\hline DG115 & 0.87 & 0.85 & 0.87 & 0,88 & 0,89 & 0,91 & 0.90 & 0,92 & 0,84 & 1,00 & & \\
\hline DG116 & 0,85 & 0,85 & 0.91 & 0,92 & 0,86 & 0,88 & 0.87 & 0,87 & 0,92 & 0,87 & 1,00 & \\
\hline DG118 & 0,87 & 0,92 & 0,84 & 0,85 & 0.89 & 0.89 & 0,87 & 0,86 & 0,86 & 0,85 & 0,86 & 1,00 \\
\hline DG138 & 0,88 & 0.86 & 0,85 & 0,89 & 0,92 & 0,90 & 0,90 & 0,91 & 0,82 & 0,91 & 0,86 & 0,85 \\
\hline DG117 & 0,89 & 0,92 & 0.85 & 0,83 & 0,88 & 0,89 & 0,88 & 0,86 & 0,86 & 0,85 & 0,85 & 0,98 \\
\hline DG119 & 0,93 & 0,91 & 0,85 & 0,85 & 0,89 & 0,87 & 0.86 & 0,87 & 0,84 & 0,87 & 0,83 & 0,89 \\
\hline DG120 & 0,88 & 0,86 & 0.85 & 0,89 & 0,91 & 0,90 & 0,91 & 0,93 & 0,83 & 0,92 & 0,87 & 0,85 \\
\hline DG121 & 0,90 & 0,90 & 0.88 & 0.91 & 0,90 & 0,92 & 0,90 & 0,90 & 0,87 & 0,89 & 0,88 & 0,89 \\
\hline DG122 & 0.86 & 0,85 & 0.84 & 0,88 & 0,88 & 0,88 & 0,87 & 0,89 & 0,86 & 0,89 & 0,85 & 0,84 \\
\hline DG123 & 0,83 & 0,84 & 0.88 & 0,89 & 0,88 & 0,85 & 0,85 & 0,86 & 0,92 & 0,84 & 0,92 & 0,84 \\
\hline DG124 & 0,91 & 0,90 & 0.84 & 0,85 & 0,86 & 0,88 & 0.87 & 0,86 & 0,86 & 0,86 & 0,85 & 0,90 \\
\hline DG125 & 0,85 & 0,86 & 0,90 & 0.90 & 0,89 & 0,85 & 0.85 & 0.87 & 0,92 & 0,87 & 0,92 & 0,83 \\
\hline DG126 & 0,91 & 0,91 & 0.84 & 0,86 & 0,89 & 0,90 & 0,89 & 0,89 & 0,84 & 0,86 & 0,84 & 0,91 \\
\hline DG127 & 0,87 & 0.88 & 0,85 & 0,87 & 0,88 & 0,88 & 0,87 & 0,86 & 0,87 & 0,86 & 0,87 & 0,91 \\
\hline DG128 & 0,90 & 0,90 & 0.86 & 0.87 & 0,89 & 0,89 & 0,88 & 0,88 & 0.85 & 0,89 & 0,86 & 0,87 \\
\hline DG129 & 0,92 & 0,90 & 0.84 & 0.85 & 0.89 & 0,89 & 0,87 & 0.89 & 0.87 & 0,86 & 0,86 & 0,90 \\
\hline DG130 & 0.92 & 0.90 & 0,84 & 0,87 & 0,91 & 0,89 & 0,90 & 0,90 & 0,87 & 0,86 & 0.87 & 0,91 \\
\hline DG131 & 0,89 & 0,88 & 0.86 & 0,86 & 0,88 & 0,87 & 0.87 & 0,88 & 0,85 & 0,89 & 0.84 & 0,87 \\
\hline DG132 & 0,92 & 0,91 & 0,84 & 0,86 & 0,90 & 0,89 & 0.90 & 0,89 & 0,86 & 0,86 & 0,86 & 0,90 \\
\hline DG133 & 0.88 & 0,88 & 0,84 & 0,87 & 0.87 & 0.87 & 0.88 & 0,84 & 0,85 & 0,87 & 0.86 & 0,91 \\
\hline DG134 & 0,88 & 0,90 & 0.88 & 0,88 & 0.87 & 0,87 & 0.86 & 0.88 & 0.89 & 0.86 & 0,87 & 0,87 \\
\hline DG137 & 0.92 & 0,90 & 0.86 & 0,87 & 0.90 & 0,87 & 0.88 & 0,88 & 0.83 & 0.88 & 0,84 & 0,91 \\
\hline
\end{tabular}


Anexo 10 - Indices de similaridade (Nei \& Li) entre 55 variedades de mandioca,

a partir de 156 bandas de RAPD (Continuação)

\begin{tabular}{|c|c|c|c|c|c|c|c|c|c|c|c|c|}
\hline & DG138 & DG117 & DG119 & DG120 & DG121 & DG122 & DG123 & DG124 & DG125 & DG126 & DG127 & DG128 \\
\hline \multicolumn{13}{|l|}{ DG038 } \\
\hline \multicolumn{13}{|l|}{ DG039 } \\
\hline \multicolumn{13}{|l|}{ DG040 } \\
\hline \multicolumn{13}{|l|}{ DG041 } \\
\hline \multicolumn{13}{|l|}{ DG042 } \\
\hline \multicolumn{13}{|l|}{ DG043 } \\
\hline \multicolumn{13}{|l|}{ DG044 } \\
\hline \multicolumn{13}{|l|}{ DG045 } \\
\hline \multicolumn{13}{|l|}{ DG046 } \\
\hline \multicolumn{13}{|l|}{ DG047 } \\
\hline \multicolumn{13}{|l|}{ DG048 } \\
\hline \multicolumn{13}{|l|}{ DG049 } \\
\hline \multicolumn{13}{|l|}{ DG050 } \\
\hline \multicolumn{13}{|l|}{ DG051 } \\
\hline \multicolumn{13}{|l|}{ DG052 } \\
\hline DG054 & & & & & & & & & & & & \\
\hline DG055 & & & & & & & & & & & & \\
\hline DG056 & & & & & & & & & & & & \\
\hline DG058 & & & & & & & & & & & & \\
\hline DG059 & & & & & & & & & & & & \\
\hline DG060 & & & & & & & & & & & & \\
\hline DG061 & & & & & & & & & & & & \\
\hline DG062 & & & & & & & & & & & & \\
\hline DG065 & & & & & & & & & & & & \\
\hline DG067 & & & & & & & & & & & & \\
\hline DG068 & & & & & & & & & & & & \\
\hline DG069 & & & & & & & & & & & & \\
\hline DG070 & & & & & & & & & & & & \\
\hline DG073 & & & & & & & & & & & & \\
\hline DG111 & & & & & & & & & & & & \\
\hline DG112 & & & & & & & & & & & & \\
\hline DG113 & & & & & & & & & & & & \\
\hline DG114 & & & & & & & & & & & & \\
\hline DG115 & & & & & & & & & & & & \\
\hline DG116 & & & & & & & & & & & & \\
\hline DG118 & & & & & & & & & & & & \\
\hline DG138 & 1,00 & & & & & & & & & & & \\
\hline DG117 & 0,85 & 1,00 & & & & & & & & & & \\
\hline DG119 & 0,88 & 0,90 & 1.00 & & & & & & & & & \\
\hline DG120 & 0,98 & 0,84 & 0,88 & 1,00 & & & & & & & & \\
\hline DG121 & 0,90 & 0.88 & 0,90 & 0,91 & 1,00 & & & & & & & \\
\hline DG122 & 0,89 & 0,84 & 0,86 & 0,90 & 0,92 & 1.00 & & & & & & \\
\hline DG123 & 0,86 & 0,85 & 0,84 & 0,85 & 0,86 & 0,85 & 1,00 & & & & & \\
\hline DG124 & 0,86 & 0,93 & 0,94 & 0,86 & 0,89 & 0.86 & 0,87 & 1,00 & & & & \\
\hline DG125 & 0,87 & 0,83 & 0,86 & 0,87 & 0,88 & 0,87 & 0.97 & 0,88 & 1,00 & & & \\
\hline DG126 & 0,90 & 0,91 & 0,92 & 0,89 & 0,87 & 0.86 & 0,85 & 0,92 & 0.85 & 1,00 & & \\
\hline DG127 & 0,85 & 0,90 & 0,89 & 0,86 & 0,90 & 0,89 & 0.85 & 0,89 & 0.85 & 0,89 & 1,00 & \\
\hline DG128 & 0,89 & 0,87 & 0,91 & 0,90 & 0,92 & 0.89 & 0.84 & 0,89 & 0.86 & 0,92 & 0,91 & 1,00 \\
\hline DG129 & 0,89 & 0,89 & 0.91 & 0.89 & 0.89 & 0,88 & 0,83 & 0.88 & 0,84 & 0,92 & 0,93 & 0,91 \\
\hline DG130 & 0,90 & 0,90 & 0.91 & 0,90 & 0,90 & 0.88 & 0.84 & 0,90 & 0.85 & 0,95 & 0,93 & 0,92 \\
\hline DG131 & 0,89 & 0.87 & 0,91 & 0,89 & 0,91 & 0.90 & 0.85 & 0,90 & 0,88 & 0,91 & 0,91 & 0,97 \\
\hline DG132 & 0,89 & 0,91 & 0.92 & 0.89 & 0,90 & 0,88 & 0.83 & 0,91 & 0,85 & 0,95 & 0,94 & 0,93 \\
\hline DG133 & 0,88 & 0,89 & 0,91 & 0,87 & 0,90 & 0.88 & 0,84 & 0,90 & 0.85 & 0,93 & 0,93 & 0,93 \\
\hline DG134 & 0,86 & 0,87 & 0,89 & 0,87 & 0,87 & 0.84 & 0,85 & 0,89 & 0,88 & 0.88 & 0.89 & 0,88 \\
\hline DG137 & 0,89 & 0,92 & 0.92 & 0.88 & 0.91 & 0.87 & 0,83 & 0.90 & 0,84 & 0,92 & 0,89 & 0,92 \\
\hline
\end{tabular}


Anexo 10 - Índices de similaridade (Nei \& Li) entre 55 variedades de mandioca, a partir de 156 bandas de RAPD (Continuação)

\begin{tabular}{|c|c|c|c|c|c|c|c|}
\hline & DG129 & DG130 & DG131 & DG132 & DG133 & DG134 & DG137 \\
\hline \multicolumn{8}{|l|}{ DG038 } \\
\hline \multicolumn{8}{|l|}{ DG039 } \\
\hline \multicolumn{8}{|l|}{ DG040 } \\
\hline \multicolumn{8}{|l|}{ DG041 } \\
\hline \multicolumn{8}{|l|}{$\mathrm{DG} 042$} \\
\hline \multicolumn{8}{|l|}{ DG043 } \\
\hline \multicolumn{8}{|l|}{ DG044 } \\
\hline \multicolumn{8}{|l|}{ DGO45 } \\
\hline \multicolumn{8}{|l|}{ DG046 } \\
\hline \multicolumn{8}{|l|}{ DG047 } \\
\hline \multicolumn{8}{|l|}{ DG048 } \\
\hline \multicolumn{8}{|l|}{ DG049 } \\
\hline \multicolumn{8}{|l|}{ DG050 } \\
\hline \multicolumn{8}{|l|}{ DG051 } \\
\hline \multicolumn{8}{|l|}{ DG052 } \\
\hline \multicolumn{8}{|l|}{ DG054 } \\
\hline \multicolumn{8}{|l|}{ DG055 } \\
\hline DG056 & & & & & & & \\
\hline DG058 & & & & & & & \\
\hline DG059 & & & & & & & \\
\hline DG060 & & & & & & & \\
\hline DG061 & & & & & & & \\
\hline DG062 & & & & & & & \\
\hline DG065 & & & & & & & \\
\hline DG067 & & & & & & & \\
\hline DG068 & & & & & & & \\
\hline DG069 & & & & & & & \\
\hline DG070 & & & & & & & \\
\hline DG073 & & & & & & & \\
\hline DG111 & & & & & & & \\
\hline DG112 & & & & & & & \\
\hline DG113 & & & & & & & \\
\hline DG114 & & & & & & & \\
\hline DG115 & & & & & & & \\
\hline DG116 & & & & & & & \\
\hline DG118 & & & & & & & \\
\hline DG138 & & & & & & & \\
\hline DG117 & & & & & & & \\
\hline DG119 & & & & & & & \\
\hline DG120 & & & & & & & \\
\hline DG121 & & & & & & & \\
\hline DG122 & & & & & & & \\
\hline DG123 & & & & & & & \\
\hline DG124 & & & & & & & \\
\hline DG125 & & & & & & & \\
\hline DG126 & & & & & & & \\
\hline DG127 & & & & & & & \\
\hline DG128 & & & & & & & \\
\hline DG129 & 1,00 & & & & & & \\
\hline DG130 & 0.96 & 1,00 & & & & & \\
\hline DG131 & 0,91 & 0,91 & 1,00 & & & & \\
\hline DG132 & 0.95 & 0,98 & 0,92 & 1,00 & & & \\
\hline DG133 & 0,92 & 0,93 & 0,93 & 0,92 & 1,00 & & \\
\hline DG134 & 0.88 & 0,90 & 0,87 & 0.90 & 0,87 & 1,00 & \\
\hline DG137 & 0,91 & 0.93 & 0,91 & 0,93 & 0,93 & 0,90 & 1.00 \\
\hline
\end{tabular}


Anexo 11 - Indices de similaridade (Nei e Li) entre 55 variedades de mandioca,

a partir de 134 bandas de AFLP

\begin{tabular}{|c|c|c|c|c|c|c|c|c|c|c|c|c|}
\hline & DG038 & DG039 & $\mathrm{DG} 040$ & DG041 & DG042 & $\mathrm{DG} 043$ & DG044 & DG045 & DG046 & DG047 & DG048 & DG049 \\
\hline DG038 & 1.00 & & & & & & & & & & & \\
\hline DG039 & 0.79 & 1.00 & & & & & & & & & & \\
\hline DG040 & 0.88 & 0.80 & 1.00 & & & & & & & & & \\
\hline DG041 & 0,83 & 0,78 & 0.89 & 1.00 & & & & & & & & \\
\hline DG042 & 0.88 & 0.80 & 0.87 & 0,80 & 1.00 & & & & & & & \\
\hline DG0.43 & 0.88 & 0.81 & 0.87 & 0.82 & 0.87 & 1.00 & & & & & & \\
\hline DG044 & 0,89 & 0.80 & 0.87 & 0,84 & 0.82 & 0.87 & 1.00 & & & & & \\
\hline DG045 & 0.83 & 0.81 & $0,8.4$ & 0.81 & 0.83 & 0.85 & 0.84 & 1.00 & & & & \\
\hline DG046 & 0,86 & 0.75 & 0.87 & 0,83 & 0,84 & 0.86 & 0,86 & 0.84 & 1,00 & & & \\
\hline DGO47 & 0,86 & 0.84 & 0.85 & 0,81 & 0.83 & 0.85 & 0.83 & 0,82 & 0.82 & 1,00 & & \\
\hline DG048 & 0,84 & 0.83 & 0,84 & 0,84 & 0.88 & 0,86 & 0.84 & 0.82 & 0,84 & 0.83 & 1,00 & \\
\hline DG049 & 0,89 & 0,83 & 0.87 & 0,82 & 0,89 & 0.91 & 0,87 & 0,86 & 0.85 & 0,88 & 0,88 & 1,00 \\
\hline DG050 & 0,86 & 0,82 & 0.87 & 0,84 & 0.84 & 0.86 & 0,87 & 0,84 & 0.85 & 0.84 & 0,86 & 0,91 \\
\hline DG051 & 0,88 & 0.82 & 0,87 & 0,81 & 0,86 & 0.97 & 0.86 & 0,87 & 0,85 & 0,88 & 0.87 & 0,92 \\
\hline DG052 & 0,84 & 0.80 & 0.86 & 0,81 & 0.84 & 0.87 & 0.84 & 0.82 & 0.88 & 0,88 & 0,83 & 0,87 \\
\hline DG054 & 0.86 & 0,81 & 0.88 & 0,86 & 0.86 & 0.87 & 0.85 & 0,83 & 0.85 & 0.88 & 0,87 & 0.88 \\
\hline DG055 & 0.87 & 0.83 & 0.87 & 0,83 & 0.88 & 0.87 & 0.83 & 0,86 & 0.82 & 0,83 & 0.84 & 0,87 \\
\hline DG056 & 0,85 & 0.81 & 0.87 & 0.83 & 0.85 & 0.86 & 0.84 & 0.82 & 0.83 & 0,86 & 0,86 & 0,85 \\
\hline DG058 & 0,88 & 0.83 & 0.86 & 0,82 & 0,85 & 0.88 & 0.85 & 0,84 & 0.83 & 0,85 & 0.85 & 0,88 \\
\hline DG059 & 0,89 & 0,84 & 0,86 & 0,83 & 0.89 & 0.91 & 0,87 & 0,85 & 0.86 & 0,88 & 0,89 & 0,99 \\
\hline DG060 & 0,87 & 0.78 & 0.86 & 0,82 & 0,84 & 0,85 & 0.86 & 0.80 & 0,91 & 0,85 & 0,85 & 0,85 \\
\hline DG061 & 0,86 & 0.83 & 0,85 & 0,82 & 0,84 & 0.86 & 0.84 & 0,98 & 0,83 & 0.84 & 0,85 & 0.88 \\
\hline DG062 & 0,83 & 0,80 & 0,81 & 0,81 & 0,81 & 0.86 & 0.81 & 0,84 & 0,81 & 0.80 & 0,81 & 0,86 \\
\hline DG065 & 0,82 & 0.86 & 0.83 & 0,78 & 0,78 & 0,83 & 0.86 & 0,80 & 0,79 & 0,85 & 0,80 & 0,86 \\
\hline DG067 & 0,85 & 0,84 & 0,85 & 0,79 & 0,81 & 0,84 & 0.86 & 0,84 & 0,81 & 0,87 & 0,83 & 0,88 \\
\hline DG068 & 0,84 & 0,83 & 0.83 & 0,80 & 0,83 & 0,85 & 0,83 & 0,98 & 0.82 & 0,83 & 0,84 & 0,87 \\
\hline DG069 & 0,81 & 0,84 & 0,87 & 0,80 & 0,82 & 0.84 & 0.89 & 0,82 & 0.82 & 0,85 & 0,80 & 0,86 \\
\hline DG070 & 0,86 & 0,83 & 0,89 & 0,84 & 0,84 & 0,87 & 0,86 & 0,84 & 0,82 & 0,89 & 0,84 & 0,91 \\
\hline DG073 & 0,84 & 0,84 & 0,85 & 0.83 & 0,85 & 0.84 & 0,85 & 0,85 & 0.83 & 0,85 & 0,86 & 0,86 \\
\hline DG111 & 0,92 & 0.81 & 0,87 & 0,84 & 0,87 & 0.86 & 0.87 & 0.85 & 0,85 & 0,87 & 0,86 & 0,86 \\
\hline DG112 & 0,97 & 0.79 & 0.88 & 0.83 & 0,86 & 0.85 & 0.87 & 0,83 & 0,83 & 0,86 & 0,85 & 0,89 \\
\hline DG113 & 0,88 & 0.82 & 0.90 & 0,84 & 0,86 & 0.84 & 0.85 & 0,84 & 0.83 & 0,87 & 0,87 & 0,88 \\
\hline DG114 & 0.88 & 0,80 & 0.88 & 0,81 & 0,87 & 0.86 & 0.85 & 0,82 & 0.88 & 0,88 & 0,86 & 0,90 \\
\hline DG115 & 0,84 & 0,80 & 0.86 & 0,84 & 0,86 & 0.84 & 0,85 & 0,83 & 0,84 & 0,84 & 0,87 & 0,84 \\
\hline DG116 & 0,85 & 0,79 & 0,83 & 0,81 & 0,82 & 0,82 & 0.81 & 0,84 & 0,80 & 0,85 & 0,87 & 0,86 \\
\hline DG118 & 0,80 & 0,84 & 0,80 & 0,78 & 0.78 & 0,82 & 0,79 & 0,84 & 0,75 & 0,82 & 0,78 & 0,82 \\
\hline DG138 & 0,87 & 0,83 & 0,86 & 0,83 & 0,89 & 0,87 & 0.83 & 0,86 & 0,85 & 0,87 & 0,89 & 0,91 \\
\hline DG117 & 0,80 & 0,84 & 0,80 & 0,78 & 0,78 & 0,82 & 0.79 & 0,84 & 0,75 & 0,82 & 0,78 & 0,82 \\
\hline DG119 & 0,83 & 0.88 & 0,83 & 0,79 & 0,81 & 0.82 & 0.85 & 0,88 & 0,78 & 0,83 & 0,82 & 0,85 \\
\hline DG120 & 0,86 & 0,83 & 0,85 & 0,81 & 0.88 & 0.86 & 0,81 & 0,86 & 0,84 & 0,86 & 0,88 & 0,90 \\
\hline DG121 & 0,83 & 0,87 & 0.84 & 0,81 & 0,81 & 0.83 & 0.85 & 0,81 & 0,81 & 0,88 & 0,84 & 0,89 \\
\hline DG122 & 0,84 & 0,82 & 0,80 & 0,75 & 0,88 & 0.82 & 0,79 & 0,79 & 0,82 & 0,82 & 0,87 & 0,87 \\
\hline DG123 & 0,86 & 0,82 & 0,81 & 0,79 & 0,88 & 0,85 & 0,83 & 0,83 & 0,81 & 0,86 & 0,86 & 0,86 \\
\hline DG124 & 0,82 & 0.85 & 0.82 & 0,79 & 0,81 & 0,81 & 0,82 & 0,87 & 0,81 & 0,86 & 0,82 & 0,84 \\
\hline DG125 & 0.84 & 0,79 & 0.84 & 0,81 & 0,83 & 0,86 & 0,85 & 0,82 & 0,83 & 0,85 & 0,84 & 0,86 \\
\hline DG126 & 0,81 & 0.88 & 0.83 & 0,80 & 0.79 & 0,83 & 0.82 & 0,83 & 0.79 & 0,83 & 0,82 & 0,85 \\
\hline DG127 & 0,81 & 0,86 & 0,84 & 0,81 & 0,78 & 0,80 & 0.81 & 0,82 & 0,79 & 0,86 & 0.82 & 0,84 \\
\hline DG128 & 0,79 & 0.90 & 0.81 & 0,79 & 0,78 & 0.83 & 0.82 & 0,81 & 0,76 & 0,83 & 0,80 & 0,85 \\
\hline DG129 & 0,79 & 0.88 & 0.82 & 0.77 & 0,81 & 0,81 & 0.81 & 0.83 & 0,78 & 0,83 & 0,81 & 0,83 \\
\hline DG130 & 0,82 & 0,88 & 0,84 & 0,80 & 0.82 & 0.86 & 0.83 & 0,84 & 0,80 & 0,85 & 0,85 & 0,87 \\
\hline DG131 & 0,79 & 0,90 & 0.80 & 0,79 & 0,78 & 0.84 & 0.81 & 0,81 & 0,75 & 0,83 & 0,79 & 0,84 \\
\hline DG132 & 0,83 & 0,88 & 0,85 & 0,81 & 0,82 & 0.87 & 0.83 & 0,84 & 0,80 & 0,86 & 0,85 & 0,87 \\
\hline DG133 & 0,78 & 0,88 & 0.80 & 0,76 & 0,80 & 0.81 & 0,82 & 0.83 & 0.78 & 0.80 & 0.80 & 0,85 \\
\hline DG134 & 0,79 & 0.85 & 0,82 & 0,78 & 0.80 & 0.84 & 0,82 & 0,84 & 0,79 & 0,84 & 0,81 & 0,85 \\
\hline DG137 & \begin{tabular}{ll|}
0.82 \\
\end{tabular} & 0,86 & 0.82 & 0.78 & 0,80 & 0,82 & 0.83 & 0.83 & 0,80 & 0.86 & 0.83 & 0,88 \\
\hline
\end{tabular}


Anexo 11 - Indices de similaridade (Nei e Li) entre 55 variedades de mandioca,

a partir de 134 bandas de AFLP (Continuação)

\begin{tabular}{|c|c|c|c|c|c|c|c|c|c|c|c|c|}
\hline & DG050 & DG051 & DG052 & DG054 & DG055 & DG056 & DG058 & DG059 & DG060 & DG061 & DG062 & DG065 \\
\hline \multicolumn{13}{|l|}{ DG038 } \\
\hline \multicolumn{13}{|l|}{ DG039 } \\
\hline \multicolumn{13}{|l|}{ DG040 } \\
\hline \multicolumn{13}{|l|}{ DG041 } \\
\hline \multicolumn{13}{|l|}{$\mathrm{DG} 042$} \\
\hline \multicolumn{13}{|l|}{ DG043 } \\
\hline \multicolumn{13}{|l|}{ DG044 } \\
\hline \multicolumn{13}{|l|}{ DG045 } \\
\hline \multicolumn{13}{|l|}{ DG046 } \\
\hline \multicolumn{13}{|l|}{ DG047 } \\
\hline \multicolumn{13}{|l|}{ DG048 } \\
\hline \multicolumn{13}{|l|}{ DG049 } \\
\hline DG050 & 1,00 & & & & & & & & & & & \\
\hline DG051 & 0,87 & 1,00 & & & & & & & & & & \\
\hline DG052 & 0,85 & 0,87 & 1,00 & & & & & & & & & \\
\hline DG054 & 0.85 & 0.88 & 0,89 & 1,00 & & & & & & & & \\
\hline DG055 & 0,84 & 0.89 & 0.84 & 0.87 & 1.00 & & & & & & & \\
\hline DG056 & 0.84 & 0.87 & 0,85 & 0,90 & 0.84 & 1,00 & & & & & & \\
\hline DG058 & 0.83 & 0,87 & 0,86 & 0,87 & 0,91 & 0.84 & 1,00 & & & & & \\
\hline DG059 & 0,92 & 0,92 & 0,88 & 0,89 & 0.88 & 0,86 & 0,89 & 1.00 & & & & \\
\hline DG060 & 0,86 & 0,85 & 0,86 & 0,88 & 0,83 & 0.85 & 0.85 & 0.86 & 1,00 & & & \\
\hline DG061 & 0,85 & 0,89 & 0,84 & 0,86 & 0,88 & 0,85 & 0,87 & 0,88 & 0,82 & 1,00 & & \\
\hline DG062 & 0,81 & 0,84 & 0,81 & 0,82 & 0.87 & 0,80 & 0,93 & 0,87 & 0.78 & 0,85 & 1,00 & \\
\hline DG065 & 0,85 & 0,84 & 0,82 & 0,84 & 0,80 & 0,83 & 0,84 & 0,86 & 0,84 & 0,83 & 0,82 & 1,00 \\
\hline DG067 & 0,85 & 0,86 & 0,83 & 0,85 & 0,85 & 0,85 & 0,85 & 0,88 & 0,85 & 0,86 & 0,83 & 0,88 \\
\hline DG068 & 0,84 & 0,89 & 0,82 & 0,85 & 0,88 & 0,83 & 0,85 & 0,87 & 0,81 & 0,99 & 0,84 & 0,82 \\
\hline DG069 & 0,84 & 0,85 & 0,82 & 0,81 & 0,81 & 0,83 & 0,81 & 0,85 & 0,83 & 0,82 & 0,77 & 0,87 \\
\hline DG070 & 0,87 & 0,88 & 0,86 & 0,88 & 0,87 & 0,85 & 0,86 & 0,90 & 0,85 & 0,87 & 0,82 & 0,86 \\
\hline DG073 & 0,87 & 0,85 & 0,83 & 0,86 & 0,86 & 0,86 & 0,84 & 0.87 & 0,83 & 0,88 & 0,81 & 0,85 \\
\hline DG111 & 0,84 & 0,87 & 0,87 & 0,88 & 0,88 & 0,87 & 0.89 & 0,87 & 0.86 & 0,86 & 0.83 & 0,82 \\
\hline DG112 & 0.85 & 0,86 & 0,83 & 0,86 & 0.85 & 0,83 & 0.86 & 0.88 & 0.86 & 0.85 & 0,80 & 0,81 \\
\hline DG113 & 0.85 & 0,86 & 0.85 & 0,88 & 0,87 & 0,85 & 0,90 & 0.88 & 0.85 & 0,85 & 0,83 & 0,86 \\
\hline DG114 & 0,85 & 0,86 & 0,86 & 0,86 & 0,86 & 0,84 & 0.87 & 0.88 & 0,89 & 0,85 & 0,80 & 0,82 \\
\hline DG115 & 0,84 & 0,85 & 0,85 & 0,85 & 0.82 & 0,85 & 0,85 & 0.85 & 0.87 & 0,85 & 0,78 & 0,82 \\
\hline DG116 & 0.86 & 0,86 & 0,83 & 0.85 & 0,81 & 0,78 & 0,84 & 0,86 & 0,82 & 0,86 & 0,78 & 0,80 \\
\hline DG118 & 0,79 & 0,83 & 0,81 & 0,80 & 0,82 & 0,80 & 0,83 & 0,82 & 0,77 & 0,86 & 0,80 & 0,83 \\
\hline DG138 & 0,87 & 0,89 & 0,88 & 0,91 & 0,90 & 0,86 & 0,90 & 0,91 & 0,85 & 0,88 & 0,83 & 0,81 \\
\hline DG117 & 0,79 & 0,83 & 0,81 & 0,80 & 0,82 & 0,80 & 0,83 & 0,82 & 0,77 & 0,86 & 0,80 & 0,83 \\
\hline DG119 & 0,84 & 0,84 & 0,81 & 0.82 & 0.82 & 0,82 & 0,83 & 0,85 & 0.81 & 0,91 & 0,80 & 0,89 \\
\hline DG120 & 0,86 & 0,89 & 0,86 & 0,90 & 0.89 & 0,84 & 0,88 & 0,90 & 0.84 & 0,87 & 0,81 & 0,81 \\
\hline DG121 & 0.86 & 0,85 & 0,87 & 0,89 & 0,82 & 0,84 & 0,81 & 0,89 & 0,83 & 0,84 & 0,78 & 0.88 \\
\hline DG122 & 0,85 & 0,83 & 0,82 & 0,86 & 0.84 & 0,84 & 0,82 & 0.88 & 0.84 & 0,82 & 0,78 & 0,81 \\
\hline DG123 & 0,83 & 0,84 & 0.85 & 0,86 & 0,83 & 0,83 & 0,83 & 0,87 & 0,79 & 0,84 & 0,81 & 0,82 \\
\hline DG124 & 0,82 & 0,83 & 0.83 & 0,85 & 0,81 & 0,82 & 0,83 & 0,85 & 0,82 & 0,89 & 0,78 & 0,84 \\
\hline DG125 & 0.85 & 0,87 & 0,86 & 0,86 & 0.83 & 0,83 & 0,86 & 0,87 & 0.85 & 0,83 & 0,81 & 0,83 \\
\hline DG126 & 0.85 & 0,84 & 0,80 & 0.82 & 0.80 & 0,81 & 0,82 & 0,86 & 0.82 & 0,86 & 0,80 & 0,88 \\
\hline DG127 & 0,84 & 0,83 & 0,80 & 0,83 & 0,80 & 0,81 & 0,81 & 0,84 & 0,84 & 0,85 & 0,79 & 0,89 \\
\hline DG128 & 0,82 & 0,84 & 0,80 & 0,82 & 0,81 & 0.80 & 0.82 & 0.85 & 0.80 & 0.84 & 0,79 & 0,87 \\
\hline DG129 & 0,81 & 0,84 & 0,81 & 0,84 & 0.80 & 0.81 & 0,80 & 0,82 & 0,83 & 0,84 & 0,76 & 0,86 \\
\hline DG130 & 0,86 & 0,87 & 0,82 & 0,85 & 0.84 & 0,79 & 0,85 & 0.88 & 0,84 & 0,86 & 0,83 & 0,86 \\
\hline DG131 & 0,81 & 0,84 & 0.80 & 0,82 & 0,82 & 0,80 & 0,83 & 0.85 & 0,80 & 0,84 & 0,80 & 0,87 \\
\hline DG132 & 0,87 & 0,88 & 0,83 & 0,85 & 0,85 & 0,80 & 0,86 & 0.88 & 0.84 & 0,87 & 0,83 & 0,86 \\
\hline DG133 & 0.82 & 0,83 & 0,82 & 0,82 & 0.81 & 0.79 & 0,82 & 0,85 & 0.81 & 0,86 & 0,80 & 0,89 \\
\hline DG134 & 0,86 & 0.87 & 0,83 & 0,82 & 0,83 & 0,80 & 0.81 & 0,85 & 0.80 & 0,87 & 0,80 & 0,86 \\
\hline DG137 & 0.84 & 0.85 & 0,83 & 0.84 & 0.82 & 0,81 & 0.84 & 0.88 & 0.83 & 0.86 & 0,81 & 0,93 \\
\hline
\end{tabular}


Anexo 11 - Indices de similaridade (Nei e Li) entre 55 variedades de mandioca,

a partir de 134 bandas de AFLP (Continuação)

\begin{tabular}{|c|c|c|c|c|c|c|c|c|c|c|c|c|}
\hline & DG067 & DG068 & DG069 & DG070 & DG073 & DG111 & DG.112 & DG 113 & DG114 & $10 G 115$ & DG 116 & DG118 \\
\hline \multicolumn{13}{|l|}{ DG038 } \\
\hline \multicolumn{13}{|l|}{ DG039 } \\
\hline \multicolumn{13}{|l|}{ DG040 } \\
\hline \multicolumn{13}{|l|}{ DG041 } \\
\hline \multicolumn{13}{|l|}{ DGO42 } \\
\hline \multicolumn{13}{|l|}{ DG043 } \\
\hline \multicolumn{13}{|l|}{ DG044 } \\
\hline \multicolumn{13}{|l|}{ DG045 } \\
\hline \multicolumn{13}{|l|}{ DG046 } \\
\hline \multicolumn{13}{|l|}{ DG047 } \\
\hline \multicolumn{13}{|l|}{ DG048 } \\
\hline \multicolumn{13}{|l|}{ DG049 } \\
\hline \multicolumn{13}{|l|}{ DG050 } \\
\hline \multicolumn{13}{|l|}{ DG051 } \\
\hline \multicolumn{13}{|l|}{ DG052 } \\
\hline DG054 & & & & & & & & & & & & \\
\hline DG055 & & & & & & & & & & & & \\
\hline DG056 & & & & & & & & & & & & \\
\hline DG058 & & & & & & & & & & & & \\
\hline DG059 & & & & & & & & & & & & \\
\hline DG060 & & & & & & & & & & & & \\
\hline DG061 & & & & & & & & & & & & \\
\hline DG062 & & & & & & & & & & & & \\
\hline DG065 & & & & & & & & & & & & \\
\hline DG067 & 1,00 & & & & & & & & & & & \\
\hline DG068 & 0,86 & 1,00 & & & & & & & & & & \\
\hline DG069 & 0,87 & 0,81 & 1,00 & & & & & & & & & \\
\hline DG070 & 0,88 & 0,85 & 0,87 & 1,00 & & & & & & & & \\
\hline DG073 & 0,84 & 0,86 & 0,85 & 0,89 & 1,00 & & & & & & & \\
\hline DG111 & 0,84 & 0,85 & 0,83 & 0,84 & 0,85 & 1,00 & & & & & & \\
\hline DG112 & 0,85 & 0,84 & 0,82 & 0,85 & 0,83 & 0,92 & 1,00 & & & & & \\
\hline DG113 & 0,88 & 0,84 & 0.83 & 0.88 & 0,84 & 0,91 & 0.89 & 1,00 & & & & \\
\hline DG114 & 0,86 & 0,84 & 0.84 & 0,87 & 0,84 & 0,86 & 0.88 & 0,88 & 1,00 & & & \\
\hline DGIIS & 0,82 & 0.85 & 0.84 & 0.85 & 0,87 & 0,88 & 0.86 & 0.87 & 0.83 & 1,00 & & \\
\hline DG116 & 0,83 & 0,87 & 0,79 & 0,84 & 0,82 & 0,85 & 0.88 & 0,87 & 0,83 & 0,85 & 1,00 & \\
\hline DG118 & 0,85 & 0,86 & 0,81 & 0,85 & 0,84 & 0,80 & 0,78 & 0,80 & 0,79 & 0.82 & 0,82 & 1,00 \\
\hline DG138 & 0,87 & 0,87 & 0,82 & 0.90 & 0,87 & 0.88 & 0.87 & 0,91 & 0,89 & 0,86 & 0,88 & 0,81 \\
\hline DG117 & 0,85 & 0,86 & 0,81 & 0,85 & 0,84 & 0,80 & 0.78 & 0,80 & 0.79 & 0,82 & 0,82 & 1,00 \\
\hline DG119 & 0,89 & 0,90 & 0.87 & 0,86 & 0,88 & 0,81 & 0,82 & 0,85 & 0,83 & 0,86 & 0,84 & 0,91 \\
\hline DG120 & 0,87 & 0,88 & 0,81 & 0,88 & 0,86 & 0,87 & 0,86 & 0,90 & 0,88 & 0,86 & 0,89 & 0,81 \\
\hline DG121 & 0,88 & 0,84 & 0,85 & 0,91 & 0,86 & 0.85 & 0,84 & 0,84 & 0,83 & 0,83 & 0.83 & 0,84 \\
\hline DG122 & 0,84 & 0,82 & 0,82 & 0.84 & 0,86 & 0,85 & 0.84 & 0,83 & 0.83 & 0,84 & 0,83 & 0,77 \\
\hline DG123 & 0,81 & 0,84 & 0,83 & 0,82 & 0,87 & 0,89 & 0,86 & 0,83 & 0,83 & 0,86 & 0,85 & 0,79 \\
\hline DG124 & 0,86 & 0,89 & 0,84 & 0.87 & 0,89 & 0,83 & 0.81 & 0,82 & 0,85 & 0,85 & 0,84 & 0,87 \\
\hline DG125 & 0,81 & 0,83 & 0,83 & 0,87 & 0,86 & 0.86 & 0.82 & 0,86 & 0,83 & 0,90 & 0,85 & 0,83 \\
\hline DG126 & 0,86 & 0,86 & 0,84 & 0,86 & 0,85 & 0,80 & 0,79 & 0.83 & 0,81 & 0,83 & 0,81 & 0,88 \\
\hline DG127 & 0,88 & 0,85 & 0,86 & 0,88 & 0,85 & 0,81 & 0.81 & 0,83 & 0,80 & 0,86 & 0,81 & 0,85 \\
\hline DG128 & 0,84 & 0,84 & 0,84 & 0.84 & 0,82 & 0,80 & 0.77 & 0,79 & 0,80 & 0,80 & 0,80 & 0.88 \\
\hline DG129 & 0.84 & 0,85 & 0,83 & 0.84 & 0,83 & 0,82 & 0.79 & 0,79 & 0,79 & 0,83 & 0,81 & 0,90 \\
\hline DG130 & 0,88 & 0,86 & 0.84 & 0,87 & 0.86 & 0,83 & 0.82 & 0,85 & 0,82 & 0,85 & 0,84 & 0,87 \\
\hline DG131 & 0.84 & 0,84 & 0.84 & 0.84 & 0,81 & 0,80 & 0.77 & 0,78 & 0,79 & 0,80 & 0,80 & 0,90 \\
\hline DG132 & 0,89 & 0,87 & 0,85 & 0.88 & 0,87 & 0,83 & 0.82 & 0,86 & 0,83 & 0.85 & 0.85 & 0,87 \\
\hline DG133 & 0.85 & 0.85 & 0.81 & 0.84 & 0,80 & 0.80 & 0.77 & 0,83 & 0,80 & 0,81 & 0,80 & 0.89 \\
\hline DG134 & 0,83 & 0,87 & 0,84 & 0.86 & 0.89 & 0,80 & 0.79 & 0,81 & 0.81 & 0,84 & 0,83 & 0,86 \\
\hline DG137 & 0,89 & 0,84 & 0,88 & 0.87 & 0,85 & 0,83 & 0.82 & 0.87 & 0.83 & 0,84 & 0.80 & 0,85 \\
\hline
\end{tabular}


Anexo 11 - Índices de similaridade (Nei e Li) entre 55 variedades de mandioca,

a partir de 134 bandas de AFLP (Continuacão)

\begin{tabular}{|c|c|c|c|c|c|c|c|c|c|c|c|c|}
\hline & DG138 & DG117 & DG119 & DG 120 & DG121 & DG122 & DG123 & DG124 & DG125 & DG126 & DG127 & DG128 \\
\hline \multicolumn{13}{|l|}{ DG038 } \\
\hline \multicolumn{13}{|l|}{ DG039 } \\
\hline \multicolumn{13}{|l|}{ DG040 } \\
\hline \multicolumn{13}{|l|}{ DG041 } \\
\hline \multicolumn{13}{|l|}{ DG 042} \\
\hline \multicolumn{13}{|l|}{ DG043 } \\
\hline \multicolumn{13}{|l|}{ DG044 } \\
\hline \multicolumn{13}{|l|}{ DG045 } \\
\hline \multicolumn{13}{|l|}{ DG046 } \\
\hline \multicolumn{13}{|l|}{ DG047 } \\
\hline \multicolumn{13}{|l|}{ DG048 } \\
\hline \multicolumn{13}{|l|}{ DG049 } \\
\hline \multicolumn{13}{|l|}{ DG050 } \\
\hline \multicolumn{13}{|l|}{ DG051 } \\
\hline \multicolumn{13}{|l|}{ DG052 } \\
\hline DG054 & & & & & & & & & & & & \\
\hline DG055 & & & & & & & & & & & & \\
\hline DG056 & & & & & & & & & & & & \\
\hline DG058 & & & & & & & & & & & & \\
\hline DG059 & & & & & & & & & & & & \\
\hline DG060 & & & & & & & & & & & & \\
\hline DG061 & & & & & & & & & & & & \\
\hline DG062 & & & & & & & & & & & & \\
\hline DG065 & & & & & & & & & & & & \\
\hline DG067 & & & & & & & & & & & & \\
\hline DG068 & & & & & & & & & & & & \\
\hline DG069 & & & & & & & & & & & & \\
\hline DG070 & & & & & & & & & & & & \\
\hline DG073 & & & & & & & & & & & & \\
\hline DG111 & & & & & & & & & & & & \\
\hline DG112 & & & & & & & & & & & & \\
\hline DG113 & & & & & & & & & & & & \\
\hline DG114 & & & & & & & & & & & & \\
\hline DG115 & & & & & & & & & & & & \\
\hline DG116 & & & & & & & & & & & & \\
\hline DG118 & & & & & & & & & & & & \\
\hline DG138 & 1,00 & & & & & & & & & & & \\
\hline DG117 & 0,81 & 1,00 & & & & & & & & & & \\
\hline DG119 & 0,85 & 0,91 & 1,00 & & & & & & & & & \\
\hline DG120 & 0.99 & 0.81 & 0,84 & 1,00 & & & & & & & & \\
\hline DG121 & 0.87 & 0,84 & 0.87 & 0.87 & 1,00 & & & & & & & \\
\hline DG122 & 0.89 & 0,77 & 0.81 & 0,88 & 0,89 & 1.00 & & & & & & \\
\hline DG123 & 0,88 & 0,79 & 0,83 & 0,87 & 0,86 & 0,89 & 1,00 & & & & & \\
\hline DG124 & 0,84 & 0,87 & 0,91 & 0,84 & 0,87 & 0,84 & 0,85 & 1.00 & & & & \\
\hline DG125 & 0.87 & 0,83 & 0.83 & 0,86 & 0,82 & 0,82 & 0,85 & 0,84 & 1.00 & & & \\
\hline DG126 & 0,82 & 0,88 & 0,90 & 0,82 & 0.87 & 0.79 & 0,79 & 0,88 & 0.82 & 1,00 & & \\
\hline DG127 & 0.82 & 0,85 & 0.88 & 0,82 & 0,88 & 0,80 & 0,83 & 0,87 & 0,83 & 0,90 & 1,00 & \\
\hline DG128 & 0.79 & 0,88 & 0.89 & 0.79 & 0.87 & 0.78 & 0.81 & 0,88 & 0.82 & 0,91 & 0,88 & 1,00 \\
\hline DG129 & 0,82 & 0,90 & 0.88 & 0.83 & 0.89 & 0.80 & 0,81 & 0,86 & 0.80 & 0,91 & 0,89 & 0,91 \\
\hline DG130 & 0.84 & 0,87 & 0,89 & 0,84 & 0.86 & 0.82 & 0,82 & 0.89 & 0.84 & 0,91 & 0.91 & 0,89 \\
\hline DG131 & 0.79 & 0,90 & 0,89 & 0,79 & 0,87 & 0.78 & 0.79 & 0.88 & 0.81 & 0.91 & 0.87 & 0,98 \\
\hline DG132 & 0,84 & 0,87 & 0,90 & 0.84 & 0.87 & 0,82 & 0,83 & 0,90 & 0.85 & 0,91 & 0,92 & 0,90 \\
\hline DG133 & 0,83 & 0,89 & 0,90 & 0,83 & 0,86 & 0.76 & 0,77 & 0.84 & 0.80 & 0,92 & 0,87 & 0,91 \\
\hline DG134 & 0.82 & 0,86 & 0.88 & 0,82 & 0.83 & 0.81 & 0.81 & 0.88 & 0.86 & 0.85 & 0.84 & 0,83 \\
\hline DG137 & 0.84 & 0,85 & 0,90 & 0.83 & 0.86 & 0.81 & 0.81 & 0.87 & 0.83 & 0,89 & 0,90 & 0,87 \\
\hline
\end{tabular}


Anexo 11 - Indices de similaridade (Nei e Li) entre 55 variedades de mandioca, a partir de 134 bandas de AFLP (Continuacão)

\begin{tabular}{|c|c|c|c|c|c|c|c|}
\hline & DG129 & DG130 & DG131 & DG132 & DG133 & DG134 & DG137 \\
\hline \multicolumn{8}{|l|}{ DG038 } \\
\hline \multicolumn{8}{|l|}{ DG039 } \\
\hline \multicolumn{8}{|l|}{ DG040 } \\
\hline \multicolumn{8}{|l|}{$D G 041$} \\
\hline \multicolumn{8}{|l|}{ DG042 } \\
\hline \multicolumn{8}{|l|}{$\mathrm{DG} 043$} \\
\hline \multicolumn{8}{|l|}{ DG044 } \\
\hline \multicolumn{8}{|l|}{ DG045 } \\
\hline \multicolumn{8}{|l|}{ DG046 } \\
\hline \multicolumn{8}{|l|}{ DG047 } \\
\hline \multicolumn{8}{|l|}{ DG048 } \\
\hline \multicolumn{8}{|l|}{ DG049 } \\
\hline \multicolumn{8}{|l|}{ DG050 } \\
\hline \multicolumn{8}{|l|}{ DG051 } \\
\hline \multicolumn{8}{|l|}{ DG052 } \\
\hline \multicolumn{8}{|l|}{ DG054 } \\
\hline \multicolumn{8}{|l|}{ DG055 } \\
\hline DG056 & & & & & & & \\
\hline DG058 & & & & & & & \\
\hline DG059 & & & & & & & \\
\hline DG060 & & & & & & & \\
\hline DG061 & & & & & & & \\
\hline DG062 & & & & & & & \\
\hline DG065 & & & & & & & \\
\hline DG067 & & & & & & & \\
\hline DG068 & & & & & & & \\
\hline DG069 & & & & & & & \\
\hline DG070 & & & & & & & \\
\hline DG073 & & & & & & & \\
\hline DG111 & & & & & & & \\
\hline DG112 & & & & & & & \\
\hline DG113 & & & & & & & \\
\hline DG114 & & & & & & & \\
\hline DG115 & & & & & & & \\
\hline DG116 & & & & & & & \\
\hline DG118 & & & & & & & \\
\hline DG138 & & & & & & & \\
\hline DG117 & & & & & & & \\
\hline DG119 & & & & & & & \\
\hline DG120 & & & & & & & \\
\hline DG121 & & & & & & & \\
\hline DG122 & & & & & & & \\
\hline DG123 & & & & & & & \\
\hline DG124 & & & & & & & \\
\hline DG125 & & & & & & & \\
\hline DG126 & & & & & & & \\
\hline DG127 & & & & & & & \\
\hline DG128 & & & & & & & \\
\hline DG129 & 1,00 & & & & & & \\
\hline DG130 & 0,88 & 1,00 & & & & & \\
\hline DG131 & 0.92 & 0,90 & 1,00 & & & & \\
\hline DG132 & 0.88 & 1,00 & 0,90 & 1.00 & & & \\
\hline DG133 & 0,90 & 0,89 & 0,92 & 0,88 & 1,00 & & \\
\hline DG134 & 0.82 & 0,87 & 0.83 & 0,88 & 0.85 & 1.00 & \\
\hline DG137 & 0.87 & 0,88 & 0,88 & 0.88 & 0.90 & 0.87 & 1,00 \\
\hline
\end{tabular}


Anexo 12 - Índices de similaridade (Nei e Li) entre 55 variedades de mandioca,

a partir de 49 bandas de microssatélites (Continuacão)

\begin{tabular}{|c|c|c|c|c|c|c|c|c|c|c|c|c|}
\hline & DG038 & DG039 & DG040 & DG041 & $\mathrm{DG} 042$ & DG0 043 & DG044 & DG045 & DG046 & DG047 & DG0.48 & $D G 049$ \\
\hline DG038 & 1,00 & & & & & & & & & & & \\
\hline DG039 & 0.53 & 1.00 & & & & & & & & & & \\
\hline DG040 & 0,61 & 0,42 & 1.00 & & & & & & & & & \\
\hline DG041 & 0.61 & 0.42 & 1,00 & 1,00 & & & & & & & & \\
\hline DG042 & 0.53 & 0.53 & 0,61 & 0,61 & 1.00 & & & & & & & \\
\hline $\mathrm{DG} 043$ & 0.56 & 0.44 & 0.65 & 0,65 & 0.44 & 1.00 & & & & & & \\
\hline DG044 & 0.51 & 0,46 & 0.65 & 0,65 & 0.51 & 0,55 & 1.00 & & & & & \\
\hline DG045 & 0,63 & 0,58 & 0.54 & 0,54 & 0,53 & 0.44 & 0.56 & 1,00 & & & & \\
\hline DG046 & 0,50 & 0.56 & 0.51 & 0,51 & 0.50 & 0.59 & 0.60 & 0,65 & 1.00 & & & \\
\hline DG047 & 0,63 & 0,57 & 0,59 & 0,59 & 0.46 & 0.67 & 0.72 & 0.56 & 0.70 & 1.00 & & \\
\hline DG048 & 0,47 & 0.53 & 0,67 & 0,67 & 0.53 & 0.63 & 0,63 & 0.47 & 0,61 & 0,74 & 1,00 & \\
\hline DG049 & 0,55 & 0,49 & 0,50 & 0,50 & 0.42 & 0.65 & 0,65 & 0.49 & 0.63 & 0,77 & 0,67 & 1,00 \\
\hline DG050 & 0,61 & 0.49 & 0,69 & 0,69 & 0,55 & 0,65 & 0,71 & 0,70 & 0,63 & 0,71 & 0,55 & 0,75 \\
\hline DG051 & 0,56 & 0.44 & 0.65 & 0,65 & 0,44 & 1,00 & 0.55 & 0,44 & 0,59 & 0,67 & 0,63 & 0,65 \\
\hline DG052 & 0.57 & 0.46 & 0.53 & 0,53 & 0,40 & 0,79 & 0,56 & 0,56 & 0.81 & 0,72 & 0,63 & 0,65 \\
\hline DG054 & 0.47 & 0,53 & 0.61 & 0,61 & 0.47 & 0,75 & 0,46 & 0,47 & 0.56 & 0.63 & 0,71 & 0,55 \\
\hline DG055 & 0,59 & 0,59 & 0,49 & 0.49 & 0.41 & 0.69 & 0,63 & 0,37 & 0.56 & 0,80 & 0,59 & 0,79 \\
\hline DG056 & 0.55 & 0,61 & 0.50 & 0,50 & 0.42 & 0.65 & 0.65 & 0,65 & 0.80 & 0,77 & 0,67 & 0.56 \\
\hline DG058 & 0.61 & 0.49 & 0,63 & 0,63 & 0.36 & 0,71 & 0.65 & 0,49 & 0.63 & 0.88 & 0,67 & 0.75 \\
\hline DG059 & 0,55 & 0,49 & 0,50 & 0,50 & 0,42 & 0,65 & 0,65 & 0,49 & 0,63 & 0,77 & 0,67 & 1,00 \\
\hline DG060 & 0,53 & 0,53 & 0.55 & 0,55 & 0.47 & 0.56 & 0,74 & 0.53 & 0.78 & 0,80 & 0,65 & 0,67 \\
\hline DG061 & 0,63 & 0,58 & 0,54 & 0,54 & 0,53 & 0,44 & 0,56 & 1,00 & 0,65 & 0,56 & 0,47 & 0,49 \\
\hline DG062 & 0,61 & 0,49 & 0,63 & 0,63 & 0,36 & 0,71 & 0,65 & 0,49 & 0.63 & 0,88 & 0,67 & 0,75 \\
\hline DG065 & 0,39 & 0,65 & 0,33 & 0,33 & 0,26 & 0,35 & 0,44 & 0,40 & 0,49 & 0,50 & 0,39 & 0,40 \\
\hline DG067 & 0,53 & 0.47 & 0,55 & 0,55 & 0.53 & 0,38 & 0,34 & 0,63 & 0,44 & 0,34 & 0,47 & 0,36 \\
\hline DG068 & 0,63 & 0,58 & 0,54 & 0,54 & 0,53 & 0,44 & 0,56 & 1,00 & 0,65 & 0,56 & 0,47 & 0,49 \\
\hline DG069 & 0,65 & 0,41 & 0,67 & 0,67 & 0,41 & 0,56 & 0,63 & 0,58 & 0,56 & 0,63 & 0,47 & 0,61 \\
\hline DG070 & 0,55 & 0,55 & 0.63 & 0,63 & 0,36 & 0.58 & 0.65 & 0,60 & 0,57 & 0,71 & 0,61 & 0,56 \\
\hline DG073 & 0,55 & 0,49 & 0.63 & 0,63 & 0,36 & 0,65 & 0,53 & 0,49 & 0,57 & 0,71 & 0,61 & 0,56 \\
\hline DG111 & 0,67 & 0.49 & 0,69 & 0,69 & 0,55 & 0,58 & 0,71 & 0,60 & 0,57 & 0,65 & 0,61 & 0,56 \\
\hline DG112 & 1,00 & 0,53 & 0,61 & 0,61 & 0,53 & 0,56 & 0,51 & 0,63 & 0,50 & 0,63 & 0,47 & 0,55 \\
\hline DG113 & 0,73 & 0,55 & 0.69 & 0,69 & 0.42 & 0,65 & 0.65 & 0,65 & 0,69 & 0,71 & 0,55 & 0.56 \\
\hline DG114 & 0,55 & 0,55 & 0.69 & 0,69 & 0,42 & 0.65 & 0,77 & 0,60 & 0.69 & 0,71 & 0,73 & 0,63 \\
\hline DG115 & 0.63 & 0,57 & 0.65 & 0,65 & 0.40 & 0,61 & 0,56 & 0.51 & 0,54 & 0,67 & 0.63 & 0,53 \\
\hline DG116 & 0,65 & 0,65 & 0,60 & 0,60 & 0,39 & 0,55 & 0,50 & 0,57 & 0.49 & 0,63 & 0,52 & 0,60 \\
\hline DG118 & 0,59 & 0.59 & 0,61 & 0,61 & 0,59 & 0,44 & 0,51 & 0,68 & 0,50 & 0,46 & 0,53 & 0,42 \\
\hline DG138 & 0,67 & 0,49 & 0,75 & 0,75 & 0,42 & 0,58 & 0,71 & 0,54 & 0,57 & 0,65 & 0,73 & 0,56 \\
\hline DG117 & 0,59 & 0,59 & 0.61 & 0.61 & 0,59 & 0,44 & 0,51 & 0,68 & 0,50 & 0,46 & 0,53 & 0,42 \\
\hline DG119 & 0,60 & 0,54 & 0.61 & 0,61 & 0,54 & 0.46 & 0.47 & 0,73 & 0.51 & 0.47 & 0,54 & 0,50 \\
\hline DG120 & 0,65 & 0,47 & 0,73 & 0,73 & 0,41 & 0,56 & 0.74 & 0.58 & 0,56 & 0,63 & 0,71 & 0,61 \\
\hline DG121 & 0,53 & 0,47 & 0,55 & 0,55 & 0,35 & 0,63 & 0,51 & 0,42 & 0,50 & 0,63 & 0,59 & 0,49 \\
\hline DG122 & 0,58 & 0.58 & 0,67 & 0.67 & 0,45 & 0,62 & 0,69 & 0,57 & 0,67 & 0,63 & 0,52 & 0,60 \\
\hline DG123 & 0,57 & 0,57 & 0,65 & 0,65 & 0,51 & 0,67 & 0,50 & 0,46 & 0,49 & 0,50 & 0,57 & 0,53 \\
\hline DG124 & 0,55 & 0.49 & 0,63 & 0,63 & 0,49 & 0,45 & 0.41 & 0,70 & 0,51 & 0,41 & 0,49 & 0,38 \\
\hline DG125 & 0,52 & 0.45 & 0,60 & 0,60 & 0,39 & 0,48 & 0,44 & 0,51 & 0,36 & 0,56 & 0,52 & 0,40 \\
\hline DG126 & 0.56 & 0,67 & 0.46 & 0,46 & 0.50 & 0.47 & 0,38 & 0,70 & 0.53 & 0,49 & 0,44 & 0,46 \\
\hline DG127 & 0,53 & 0,59 & 0.42 & 0,42 & 0.47 & 0,44 & 0,34 & 0,58 & 0,50 & 0,40 & 0,35 & 0,36 \\
\hline DG128 & 0.54 & 0.70 & 0,56 & 0,56 & 0,54 & 0.46 & 0,53 & 0,59 & 0.46 & 0.53 & 0,54 & 0,39 \\
\hline DG129 & 0,56 & 0,61 & 0,46 & 0.46 & 0,44 & 0.47 & 0,43 & 0,60 & 0,53 & 0,43 & 0,33 & 0,51 \\
\hline DG130 & 0,60 & 0,60 & 0.50 & 0,50 & 0.49 & 0,34 & 0,47 & 0,88 & 0,51 & 0,53 & 0,43 & 0,44 \\
\hline DG131 & 0,50 & 0.67 & 0.51 & 0,51 & 0.50 & 0,41 & 0.49 & 0,55 & 0.42 & 0.49 & 0,50 & 0,34 \\
\hline DG132 & 0,60 & 0,60 & 0,50 & 0,50 & 0,49 & 0,34 & 0,47 & 0.88 & 0,51 & 0,53 & 0,43 & 0,44 \\
\hline DG133 & 0.53 & 0.68 & 0,60 & 0.60 & 0,47 & 0.50 & 0,56 & 0,67 & 0,55 & 0,62 & 0,58 & 0.49 \\
\hline DG134 & 0,51 & 0,57 & 0.59 & 0,59 & 0.51 & 0,55 & 0,50 & 0,77 & 0,65 & 0,61 & 0,57 & 0.53 \\
\hline DG137 & 0,57 & 0,69 & 0,47 & 0.47 & 0,46 & 0.49 & 0.44 & 0,56 & 0,60 & 0.50 & 0,46 & 0.53 \\
\hline
\end{tabular}


Anexo 12 - Indices de similaridade (Nei e Li) entre 55 variedades de mandioca,

a partir de 49 bandas de microssatélites (Continuação)

\begin{tabular}{|c|c|c|c|c|c|c|c|c|c|c|c|c|}
\hline & DG050 & DG051 & DG052 & DG054 & DG055 & DG056 & DG058 & DG059 & DG060 & DG061 & DG062 & DG065 \\
\hline \multicolumn{13}{|l|}{ DG038 } \\
\hline \multicolumn{13}{|l|}{ DG039 } \\
\hline \multicolumn{13}{|l|}{ DG040 } \\
\hline \multicolumn{13}{|l|}{ DG041 } \\
\hline \multicolumn{13}{|l|}{ DG042 } \\
\hline \multicolumn{13}{|l|}{ DG043 } \\
\hline \multicolumn{13}{|l|}{ DG044 } \\
\hline \multicolumn{13}{|l|}{ DG045 } \\
\hline \multicolumn{13}{|l|}{ DG046 } \\
\hline \multicolumn{13}{|l|}{ DG047 } \\
\hline \multicolumn{13}{|l|}{ DG048 } \\
\hline \multicolumn{13}{|l|}{ DG049 } \\
\hline DG050 & 1.00 & & & & & & & & & & & \\
\hline DG051 & 0.65 & 1,00 & & & & & & & & & & \\
\hline DG052 & 0,65 & 0.79 & 1.00 & & & & & & & & & \\
\hline DG054 & 0.55 & 0.75 & 0,63 & 1,00 & & & & & & & & \\
\hline DG055 & 0.61 & 0,69 & 0.57 & 0,65 & 1.00 & & & & & & & \\
\hline DG056 & 0.63 & 0,65 & 0,82 & 0.61 & 0.55 & 1,00 & & & & & & \\
\hline DG058 & 0.69 & 0,71 & 0,65 & 0.61 & 0,79 & 0.63 & 1.00 & & & & & \\
\hline DG059 & 0,75 & 0,65 & 0,65 & 0,55 & 0,79 & 0.56 & 0,75 & 1,00 & & & & \\
\hline DG060 & 0,61 & 0,56 & 0,69 & 0.53 & 0,71 & 0,67 & 0.79 & 0,67 & 1.00 & & & \\
\hline DG061 & 0.70 & 0,44 & 0,56 & 0.47 & 0,37 & 0,65 & 0,49 & 0,49 & 0.53 & 1,00 & & \\
\hline DG062 & 0,69 & 0,71 & 0,65 & 0.61 & 0,79 & 0.63 & 1,00 & 0,75 & 0.79 & 0,49 & 1,00 & \\
\hline DG065 & 0,40 & 0,35 & 0,38 & 0,39 & 0.52 & 0,47 & 0,47 & 0,40 & 0.52 & 0,40 & 0,47 & 1,00 \\
\hline DG067 & 0,49 & 0,38 & 0,40 & 0.41 & 0,24 & 0,36 & 0,30 & 0,36 & 0.24 & 0,63 & 0,30 & 0,39 \\
\hline DG068 & 0,70 & 0.44 & 0,56 & 0,47 & 0,37 & 0,65 & 0,49 & 0,49 & 0,53 & 1,00 & 0,49 & 0,40 \\
\hline DG069 & 0,73 & 0,56 & 0,57 & 0,47 & 0,53 & 0.55 & 0,61 & 0,61 & 0.53 & 0,58 & 0,61 & 0,39 \\
\hline DG070 & 0,69 & 0,58 & 0,59 & 0.55 & 0.61 & 0,63 & 0,75 & 0.56 & 0.73 & 0,60 & 0,75 & 0,53 \\
\hline DG073 & 0,63 & 0,65 & 0,65 & 0,55 & 0,55 & 0,63 & 0.69 & 0,56 & 0.55 & 0,49 & 0,69 & 0,47 \\
\hline DG111 & 0,75 & 0,58 & 0,53 & 0,49 & 0,55 & 0,56 & 0,69 & 0,56 & 0.67 & 0,60 & 0,69 & 0,47 \\
\hline DG112 & 0,61 & 0,56 & 0,57 & 0,47 & 0,59 & 0,55 & 0,61 & 0,55 & 0.53 & 0,63 & 0,61 & 0,39 \\
\hline DG113 & 0,75 & 0.65 & 0.59 & 0,49 & 0,61 & 0,63 & 0,75 & 0,56 & 0.67 & 0.65 & 0,75 & 0.53 \\
\hline DG114 & 0,75 & 0.65 & 0,65 & 0,61 & 0,61 & 0,75 & 0,69 & 0,63 & 0.73 & 0,60 & 0,69 & 0,53 \\
\hline DG115 & 0.53 & 0,61 & 0,61 & 0.51 & 0,57 & 0.59 & 0,71 & 0,53 & 0.63 & 0,51 & 0,71 & 0,44 \\
\hline DG116 & 0,53 & 0.55 & 0,50 & 0,52 & 0,65 & 0,53 & 0,67 & 0,60 & 0.65 & 0,57 & 0,67 & 0,50 \\
\hline DG118 & 0,61 & 0,44 & 0,46 & 0,47 & 0,35 & 0,55 & 0,49 & 0,42 & 0.47 & 0,68 & 0,49 & 0,39 \\
\hline DG138 & 0,63 & 0,58 & 0,59 & 0.55 & 0,61 & 0.63 & 0,63 & 0,56 & 0.61 & 0,54 & 0,63 & 0,47 \\
\hline DG117 & 0,61 & 0,44 & 0,46 & 0,47 & 0,35 & 0,55 & 0,49 & 0,42 & 0.47 & 0,68 & 0,49 & 0,39 \\
\hline DG119 & 0,61 & 0.46 & 0,53 & 0,49 & 0,38 & 0,50 & 0,44 & 0,50 & 0.38 & 0,73 & 0,44 & 0,41 \\
\hline DG120 & 0,67 & 0,56 & 0,57 & 0,53 & 0.59 & 0.61 & 0,61 & 0,61 & 0,59 & 0,58 & 0,61 & 0,45 \\
\hline DG121 & 0,49 & 0,63 & 0,63 & 0,47 & 0,53 & 0.55 & 0,73 & 0,49 & 0.59 & 0,42 & 0,73 & 0,45 \\
\hline DG122 & 0,73 & 0,62 & 0,56 & 0,58 & 0.65 & 0,67 & 0.60 & 0,60 & 0.58 & 0,57 & 0,60 & 0,57 \\
\hline DG123 & 0,47 & 0,67 & 0.56 & 0,57 & 0,51 & 0,47 & 0,53 & 0,53 & 0,46 & 0,46 & 0,53 & 0,44 \\
\hline DG124 & 0,50 & 0,45 & 0,47 & 0,49 & 0,36 & 0,44 & 0,44 & 0,38 & 0,36 & 0,70 & 0,44 & 0,53 \\
\hline DG125 & 0,47 & 0,48 & 0,44 & 0,45 & 0,45 & 0.47 & 0,60 & 0,40 & 0.52 & 0,51 & 0,60 & 0,50 \\
\hline DG126 & 0,63 & 0,47 & 0,49 & 0,50 & 0.44 & 0,46 & 0,46 & 0,46 & 0.44 & 0,70 & 0,46 & 0,61 \\
\hline DG127 & 0,49 & 0,44 & 0,40 & 0,47 & 0,47 & 0,36 & 0,42 & 0,36 & 0.47 & 0,58 & 0,42 & 0,65 \\
\hline DG128 & 0,56 & 0,46 & 0,42 & 0,54 & 0,49 & 0,50 & 0,50 & 0,39 & 0.49 & 0,59 & 0,50 & 0,59 \\
\hline DG129 & 0,57 & 0,47 & 0,43 & 0,44 & 0,56 & 0,40 & 0,46 & 0,51 & 0,50 & 0,60 & 0,46 & 0,61 \\
\hline DG130 & 0.67 & 0,34 & 0.42 & 0,38 & 0,38 & 0,50 & 0.50 & 0,44 & 0.49 & 0,88 & 0,50 & 0,53 \\
\hline DG131 & 0,51 & 0.41 & 0,38 & 0,50 & 0,44 & 0,46 & 0,46 & 0,34 & 0.44 & 0,55 & 0,46 & 0,55 \\
\hline DG132 & 0,67 & 0.34 & 0,42 & 0.38 & 0,38 & 0,50 & 0,50 & 0,44 & 0.49 & 0,88 & 0,50 & 0,53 \\
\hline DG133 & 0,65 & 0,50 & 0,51 & 0.53 & 0,53 & 0,60 & 0.54 & 0,49 & 0.53 & 0.67 & 0,54 & 0,57 \\
\hline DG134 & 0,71 & 0,55 & 0.61 & 0,57 & 0.46 & 0,65 & 0,59 & 0,53 & 0.57 & 0,77 & 0,59 & 0,56 \\
\hline DG137 & 0,59 & 0.49 & 0.50 & 0.51 & 0.57 & 0.47 & 0.53 & 0,53 & 0.57 & 0,56 & 0.53 & 0,81 \\
\hline
\end{tabular}


Anexo 12 - Indices de similaridade (Nei e Li) entre 55 variedades de mandioca,

a partir de 49 bandas de microssatélites (Continuação)

\begin{tabular}{|c|c|c|c|c|c|c|c|c|c|c|c|c|}
\hline & DG067 & DG068 & DG069 & DG070 & DG073 & DG111 & DG112 & DG113 & DG114 & DG115 & DG116 & DGI18 \\
\hline \multicolumn{13}{|l|}{ DG038 } \\
\hline \multicolumn{13}{|l|}{ DG039 } \\
\hline \multicolumn{13}{|l|}{ DGO40 } \\
\hline \multicolumn{13}{|l|}{ DG041 } \\
\hline \multicolumn{13}{|l|}{ DG042 } \\
\hline \multicolumn{13}{|l|}{ DG043 } \\
\hline \multicolumn{13}{|l|}{ DG044 } \\
\hline \multicolumn{13}{|l|}{ DG045 } \\
\hline \multicolumn{13}{|l|}{ DG046 } \\
\hline \multicolumn{13}{|l|}{ DG047 } \\
\hline \multicolumn{13}{|l|}{ DG048 } \\
\hline \multicolumn{13}{|l|}{ DG049 } \\
\hline \multicolumn{13}{|l|}{ DG050 } \\
\hline \multicolumn{13}{|l|}{ DG051 } \\
\hline \multicolumn{13}{|l|}{ DG052 } \\
\hline DG054 & & & & & & & & & & & & \\
\hline DG055 & & & & & & & & & & & & \\
\hline DG056 & & & & & & & & & & & & \\
\hline DG058 & & & & & & & & & & & & \\
\hline DG059 & & & & & & & & & & & & \\
\hline DG060 & & & & & & & & & & & & \\
\hline DG061 & & & & & & & & & & & & \\
\hline DG062 & & & & & & & & & & & & \\
\hline DG065 & & & & & & & & & & & & \\
\hline DG067 & 1,00 & & & & & & & & & & & \\
\hline DG068 & 0,63 & 1,00 & & & & & & & & & & \\
\hline DG069 & 0,47 & 0,58 & 1,00 & & & & & & & & & \\
\hline DG070 & 0.42 & 0,60 & 0,61 & 1,00 & & & & & & & & \\
\hline DG073 & 0,49 & 0,49 & 0.67 & 0.75 & 1,00 & & & & & & & \\
\hline DG111 & 0.49 & 0,60 & 0,67 & 0,63 & 0,56 & 1,00 & & & & & & \\
\hline DG112 & 0,53 & 0,63 & 0.65 & 0,55 & 0,55 & 0,67 & 1,00 & & & & & \\
\hline DG113 & 0.49 & 0,65 & 0.67 & 0,75 & 0,63 & 0,81 & 0.73 & 1,00 & & & & \\
\hline DG114 & 0.42 & 0,60 & 0.67 & 0.69 & 0,56 & 0.81 & 0.55 & 0,75 & 1,00 & & & \\
\hline DG115 & 0.51 & 0,51 & 0,57 & 0.77 & 0.71 & 0,59 & 0.63 & 0,71 & 0.65 & 1,00 & & \\
\hline DG116 & 0,45 & 0,57 & 0,52 & 0,73 & 0,53 & 0,47 & 0.65 & 0,60 & 0,53 & 0,69 & 1,00 & \\
\hline DG118 & 0,65 & 0,68 & 0,59 & 0,67 & 0,55 & 0,67 & 0,59 & 0,61 & 0,67 & 0,74 & 0,58 & 1,00 \\
\hline DG138 & 0.55 & 0,54 & 0,67 & 0,69 & 0,56 & 0.69 & 0,67 & 0,75 & 0,81 & 0,71 & 0,60 & 0,61 \\
\hline DG117 & 0.65 & 0,68 & 0,59 & 0,67 & 0,55 & 0,67 & 0,59 & 0,61 & 0,67 & 0,74 & 0,58 & 1,00 \\
\hline DG119 & 0,81 & 0,73 & 0.65 & 0,56 & 0,61 & 0,56 & 0.60 & 0,56 & 0,56 & 0,68 & 0,53 & 0,76 \\
\hline DG120 & 0.59 & 0,58 & 0.71 & 0,67 & 0,55 & 0,73 & 0,65 & 0,73 & 0,85 & 0,69 & 0.58 & 0,65 \\
\hline DG121 & 0,47 & 0,42 & 0,53 & 0,73 & 0,67 & 0,55 & 0.53 & 0.67 & 0,61 & 0.86 & 0,58 & 0,65 \\
\hline DG122 & 0.45 & 0,57 & 0,71 & 0,60 & 0,60 & 0,67 & 0,58 & 0,73 & 0,73 & 0,50 & 0,57 & 0,52 \\
\hline DG123 & 0,63 & 0,46 & 0,57 & 0,53 & 0,71 & 0,47 & 0,57 & 0,47 & 0,47 & 0,67 & 0,63 & 0,63 \\
\hline DG124 & 0.73 & 0,70 & 0.55 & 0,50 & 0,50 & 0,56 & 0,55 & 0,56 & 0,50 & \begin{tabular}{l|l}
0,53 \\
\end{tabular} & 0,47 & 0,61 \\
\hline DG125 & 0,45 & 0,51 & 0,39 & 0,67 & 0,60 & 0,40 & 0,52 & 0,47 & 0.47 & 0,63 & 0,71 & 0,52 \\
\hline DG126 & 0,56 & 0,70 & 0.44 & 0,51 & 0,51 & 0,57 & 0,56 & 0,57 & 0,57 & 0,49 & 0,42 & 0,56 \\
\hline DG127 & 0,41 & 0,58 & 0,41 & 0,49 & 0.49 & 0,55 & 0.53 & 0,55 & 0,49 & 0,51 & 0,45 & 0,59 \\
\hline DG128 & 0,60 & 0,59 & 0,49 & 0,67 & 0,50 & 0,67 & 0.54 & 0,61 & 0.67 & 0,68 & 0.53 & 0,81 \\
\hline DG129 & 0,50 & 0,60 & 0.56 & 0,57 & 0,46 & 0,51 & 0.56 & 0.63 & 0,57 & 0,60 & 0,61 & 0,61 \\
\hline DG130 & 0,60 & 0.88 & 0.49 & 0,61 & 0,44 & 0,67 & 0.60 & 0,67 & 0,56 & 0,53 & 0,59 & 0,70 \\
\hline DG131 & 0,61 & 0,55 & 0.44 & 0,63 & 0.46 & 0,63 & 0.50 & 0,57 & 0,63 & 0,65 & 0,49 & 0,78 \\
\hline DG132 & 0,60 & 0,88 & 0,49 & 0,61 & 0,44 & 0,67 & 0.60 & 0,67 & 0,56 & 0,53 & 0,59 & 0,70 \\
\hline DG133 & 0.53 & 0,67 & 0,53 & 0,70 & 0,60 & 0,60 & 0,53 & 0.65 & 0,70 & 0,67 & 0.57 & 0.68 \\
\hline DG134 & 0,57 & 0,77 & 0.51 & 0.65 & 0,59 & 0,65 & 0.51 & 0,59 & 0,65 & 0,56 & 0,56 & 0,69 \\
\hline DG137 & 0,46 & 0,56 & 0.51 & 0,59 & 0.47 & 0,65 & 0,57 & 0,65 & 0,59 & 0,50 & 0,56 & 0.57 \\
\hline
\end{tabular}


Anexo 12 - Indices de similaridade (Nei e Li) entre 55 variedades de mandioca,

a partir de 49 bandas de microssatélites (Continuaçāo)

\begin{tabular}{|c|c|c|c|c|c|c|c|c|c|c|c|c|}
\hline & DG138 & DG117 & DG119 & DG120 & DG121 & DG122 & DG123 & DG124 & DG125 & DG126 & DG127 & DG128 \\
\hline \multicolumn{13}{|l|}{ DG038 } \\
\hline \multicolumn{13}{|l|}{ DG039 } \\
\hline \multicolumn{13}{|l|}{ DGO40 } \\
\hline \multicolumn{13}{|l|}{ DG041 } \\
\hline \multicolumn{13}{|l|}{ DG042 } \\
\hline \multicolumn{13}{|l|}{ DG043 } \\
\hline \multicolumn{13}{|l|}{ DG044 } \\
\hline \multicolumn{13}{|l|}{ DG045 } \\
\hline \multicolumn{13}{|l|}{ DG046 } \\
\hline \multicolumn{13}{|l|}{ DG047 } \\
\hline \multicolumn{13}{|l|}{ DG048 } \\
\hline \multicolumn{13}{|l|}{ DG049 } \\
\hline \multicolumn{13}{|l|}{ DG050 } \\
\hline \multicolumn{13}{|l|}{ DG051 } \\
\hline \multicolumn{13}{|l|}{ DG052 } \\
\hline DG054 & & & & & & & & & & & & \\
\hline DG055 & & & & & & & & & & & & \\
\hline DG056 & & & & & & & & & & & & \\
\hline DG058 & & & & & & & & & & & & \\
\hline DG059 & & & & & & & & & & & & \\
\hline DG060 & & & & & & & & & & & & \\
\hline DG061 & & & & & & & & & & & & \\
\hline DG062 & & & & & & & & & & & & \\
\hline DG065 & & & & & & & & & & & & \\
\hline DG067 & & & & & & & & & & & & \\
\hline DG068 & & & & & & & & & & & & \\
\hline DG069 & & & & & & & & & & & & \\
\hline DG070 & & & & & & & & & & & & \\
\hline DG073 & & & & & & & & & & & & \\
\hline DG111 & & & & & & & & & & & & \\
\hline DG112 & & & & & & & & & & & & \\
\hline DG113 & & & & & & & & & & & & \\
\hline DG114 & & & & & & & & & & & & \\
\hline DG115 & & & & & & & & & & & & \\
\hline DG116 & & & & & & & & & & & & \\
\hline DG118 & & & & & & & & & & & & \\
\hline DG138 & 1,00 & & & & & & & & & & & \\
\hline DG117 & 0,61 & 1,00 & & & & & & & & & & \\
\hline DG119 & 0,67 & 0,76 & 1,00 & & & & & & & & & \\
\hline DG120 & 0,97 & 0,65 & 0,70 & 1,00 & & & & & & & & \\
\hline DG121 & 0,67 & 0,65 & 0,65 & 0,65 & 1,00 & & & & & & & \\
\hline DG122 & 0,73 & 0,52 & 0,59 & 0,71 & 0,45 & 1,00 & & & & & & \\
\hline DG123 & 0,53 & 0,63 & 0,68 & 0,51 & 0.63 & 0,63 & 1,00 & & & & & \\
\hline DG124 & 0,63 & 0.61 & 0.78 & 0,61 & 0,49 & 0,60 & 0.59 & 1,00 & & & & \\
\hline DG125 & 0,47 & 0,52 & 0,53 & 0.45 & 0.58 & 0,36 & 0,56 & 0,53 & 1,00 & & & \\
\hline DG126 & 0,40 & 0,56 & 0,62 & 0.44 & 0.44 & 0.42 & 0,43 & 0.63 & 0,55 & 1,00 & & \\
\hline DG127 & 0,36 & 0,59 & 0,49 & 0,35 & 0,41 & 0.45 & 0.51 & 0,61 & 0,45 & 0.78 & 1.00 & \\
\hline DG128 & 0,61 & 0.81 & 0,65 & 0,65 & 0,60 & 0,53 & 0.53 & 0,56 & 0.47 & 0,67 & 0,65 & 1,00 \\
\hline DG129 & 0,51 & 0,61 & 0,62 & 0.56 & 0.56 & 0,55 & 0,49 & 0.57 & 0,42 & 0,74 & 0,78 & 0,67 \\
\hline DG130 & 0,50 & 0,70 & 0,65 & 0.54 & 0.43 & 0.47 & 0,37 & 0,67 & 0.53 & 0,72 & 0,70 & 0,70 \\
\hline DG131 & 0,57 & 0,78 & 0,62 & 0,61 & 0,56 & 0.49 & 0.49 & 0,51 & 0,42 & 0,63 & 0,61 & 0,97 \\
\hline DG132 & 0,50 & 0.70 & 0,65 & 0,54 & 0,43 & 0.47 & 0,37 & 0,67 & 0.53 & 0.72 & 0,70 & 0,70 \\
\hline DG133 & 0,65 & 0.68 & 0.63 & 0.68 & 0.58 & 0.57 & 0.46 & 0,54 & 0,51 & 0,75 & 0.63 & 0,88 \\
\hline DG134 & 0,53 & 0,69 & 0,68 & 0,51 & 0.46 & 0.63 & 0.56 & 0,71 & 0.56 & 0,65 & 0,69 & 0,68 \\
\hline DG137 & 0,53 & 0,57 & 0,53 & 0,51 & 0,46 & 0,63 & 0.50 & 0,65 & 0.44 & 0,70 & 0,80 & 0.68 \\
\hline
\end{tabular}


Anexo 12 - Índices de similaridade (Nei e Li) entre 55 variedades de mandioca, a partir de 49 bandas de microssatélites (Continuação)

\begin{tabular}{|c|c|c|c|c|c|c|c|}
\hline & DG129 & DG130 & DG131 & DG132 & DG133 & DG134 & DG137 \\
\hline \multicolumn{8}{|l|}{ DG038 } \\
\hline \multicolumn{8}{|l|}{ DG039 } \\
\hline \multicolumn{8}{|l|}{ DG040 } \\
\hline \multicolumn{8}{|l|}{ DG041 } \\
\hline \multicolumn{8}{|l|}{ DG042 } \\
\hline \multicolumn{8}{|l|}{ DG043 } \\
\hline \multicolumn{8}{|l|}{ DG044 } \\
\hline \multicolumn{8}{|l|}{ DG045 } \\
\hline \multicolumn{8}{|l|}{ DG046 } \\
\hline \multicolumn{8}{|l|}{ DG047 } \\
\hline \multicolumn{8}{|l|}{ DG048 } \\
\hline \multicolumn{8}{|l|}{ DG049 } \\
\hline \multicolumn{8}{|l|}{ DG050 } \\
\hline \multicolumn{8}{|l|}{ DG051 } \\
\hline \multicolumn{8}{|l|}{ DG052 } \\
\hline \multicolumn{8}{|l|}{ DG054 } \\
\hline \multicolumn{8}{|l|}{ DG055 } \\
\hline DG056 & & & & & & & \\
\hline DG058 & & & & & & & \\
\hline DG059 & & & & & & & \\
\hline DG060 & & & & & & & \\
\hline DG061 & & & & & & & \\
\hline DG062 & & & & & & & \\
\hline DG065 & & & & & & & \\
\hline DG067 & & & & & & & \\
\hline DG068 & & & & & & & \\
\hline DG069 & & & & & & & \\
\hline DG070 & & & & & & & \\
\hline DG073 & & & & & & & \\
\hline DG111 & & & & & & & \\
\hline DG112 & & & & & & & \\
\hline DG113 & & & & & & & \\
\hline DG114 & & & & & & & \\
\hline DG115 & & & & & & & \\
\hline DG116 & & & & & & & \\
\hline DG118 & & & & & & & \\
\hline DG138 & & & & & & & \\
\hline DG117 & & & & & & & \\
\hline DG119 & & & & & & & \\
\hline DG120 & & & & & & & \\
\hline DG121 & & & & & & & \\
\hline DG122 & & & & & & & \\
\hline DG123 & & & & & & & \\
\hline DG124 & & & & & & & \\
\hline DG125 & & & & & & & \\
\hline DG126 & & & & & & & \\
\hline DG127 & & & & & & & \\
\hline DG128 & & & & & & & \\
\hline DG129 & 1,00 & & & & & & \\
\hline DG130 & 0,67 & 1,00 & & & & & \\
\hline DG131 & 0.63 & 0,67 & 1.00 & & & & \\
\hline DG132 & 0.67 & 1,00 & 0,67 & 1,00 & & & \\
\hline DG133 & 0,75 & 0,73 & 0.85 & 0.73 & 1,00 & & \\
\hline DG134 & 0.54 & 0,79 & 0,65 & 0,79 & 0.67 & 1.00 & \\
\hline DG137 & 0.70 & 0,68 & 0.65 & 0.68 & 0,62 & 0,72 & 1.00 \\
\hline
\end{tabular}


Anexo 13 - Correlações entre matrizes de similaridade

Indice de similaridade de Nei e Li. Correlaçôes produto-momento (r) *

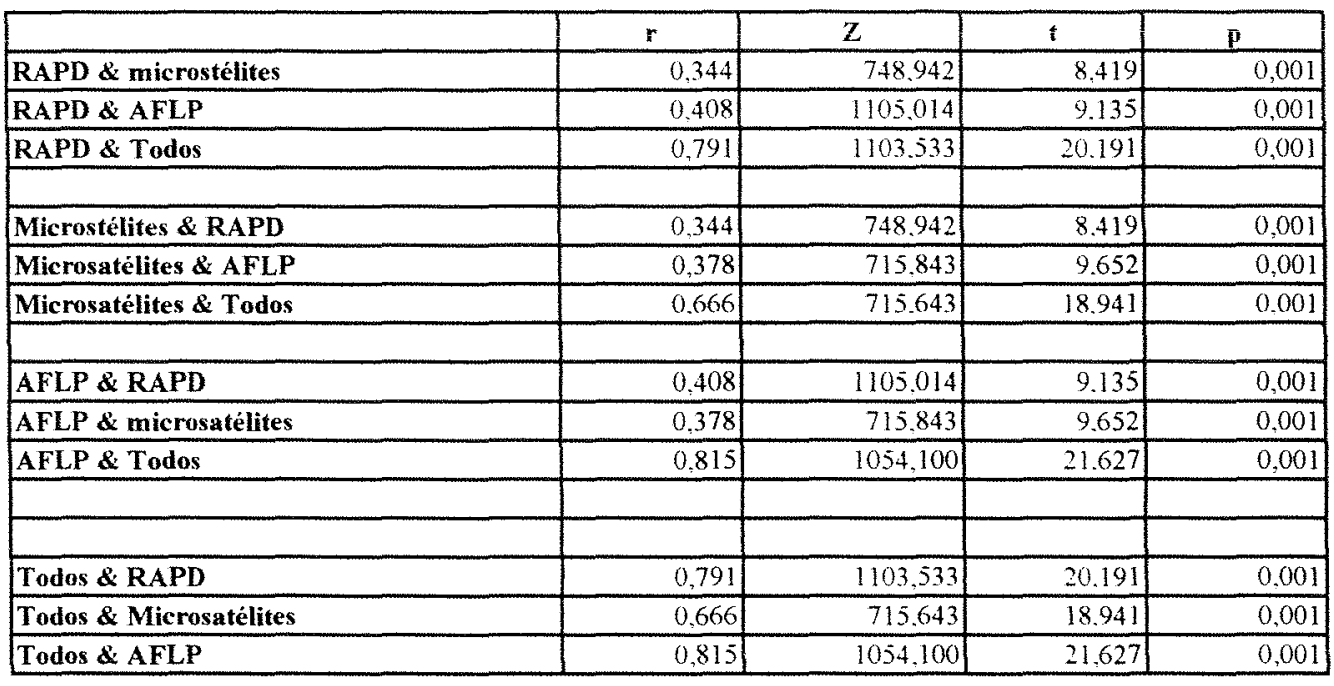

(*) $\mathrm{H}_{\mathrm{T}}=$ Diversidade média total

$\mathrm{H}_{\mathrm{S}}=$ Diversidade média nos grupos

$\mathrm{G}_{\mathrm{ST}}=$ Coeficiente de diferenciação genética

Índice de similaridade de Nei e Li. Correlações por ordenação, de Spearman

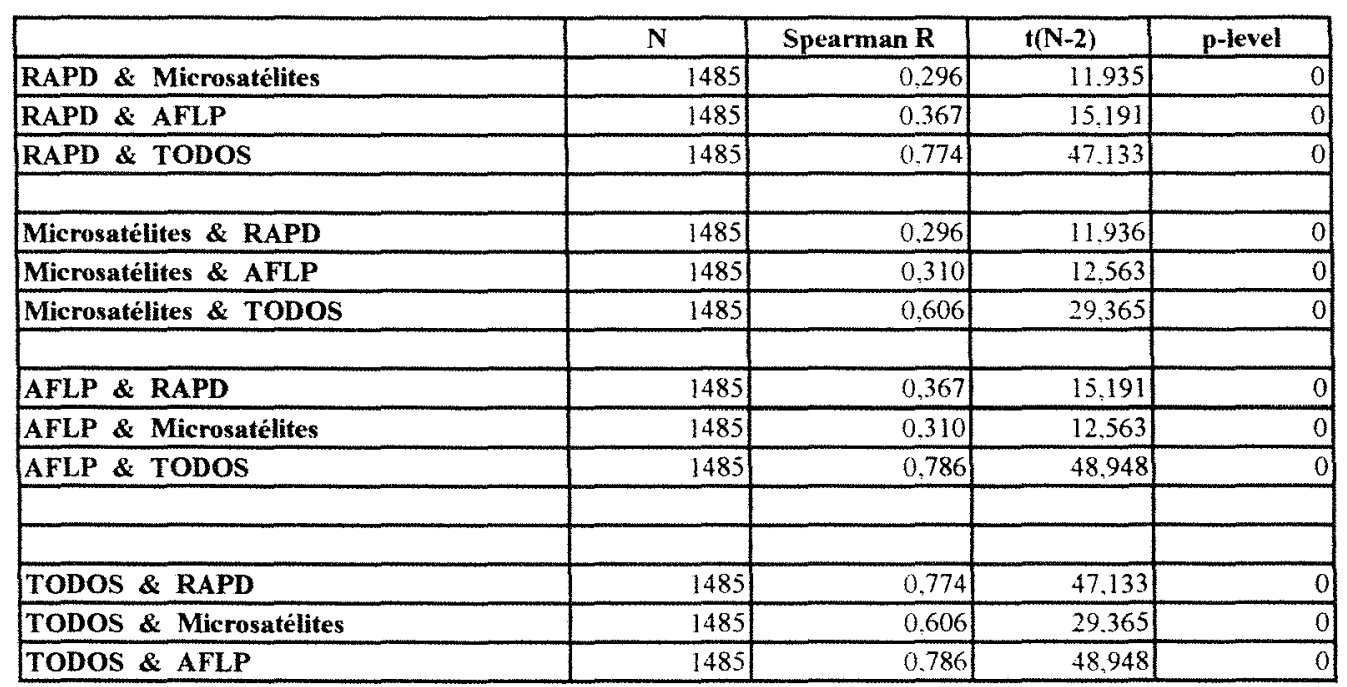

